Historic, archived document

Do not assume content reflects current scientific knowledge, policies, or practices. 



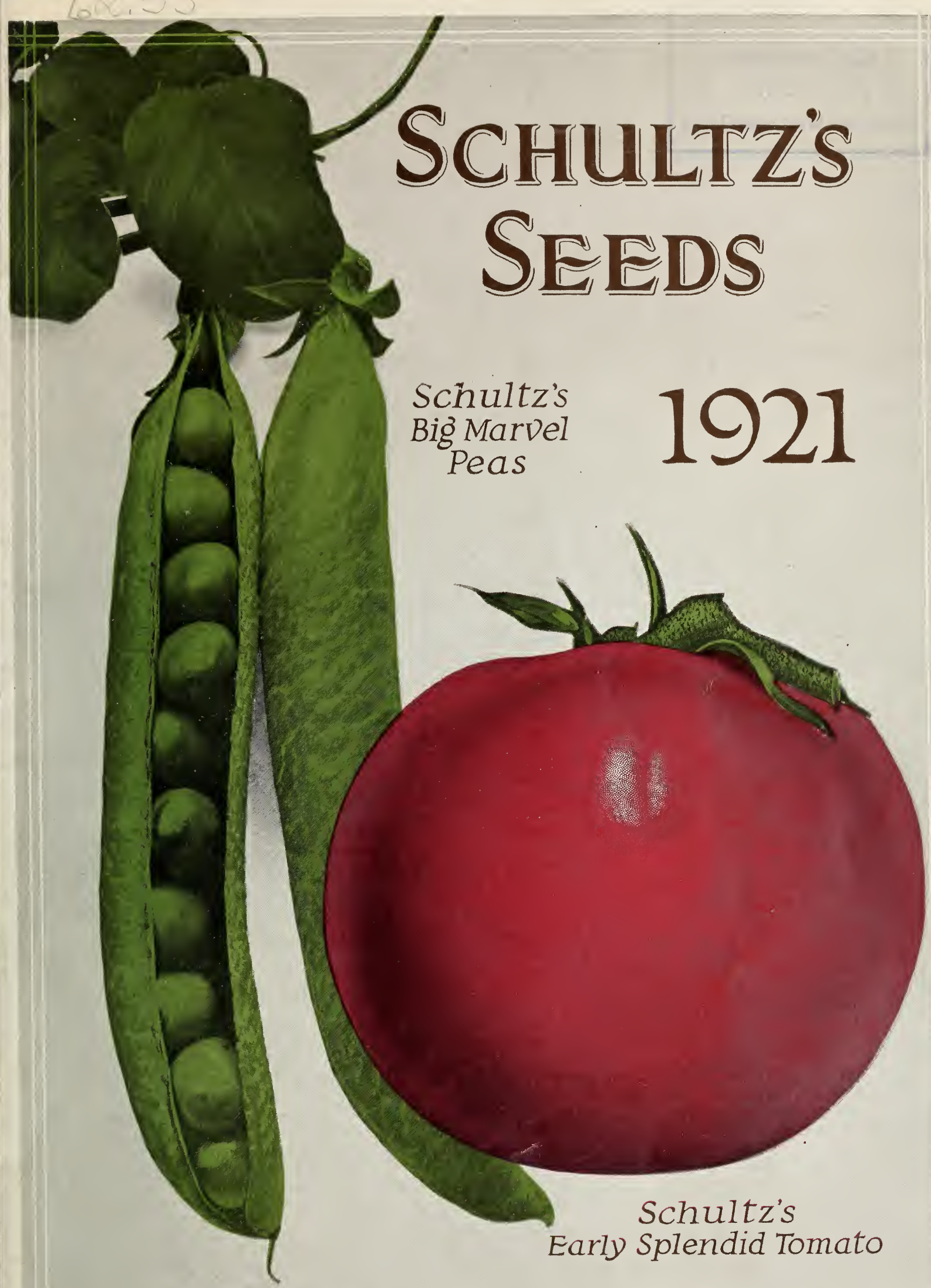

\section{Schultz's Seed Store 304 Tenth St., N.W - - Washington, D.C.}


Parcel-Post Zone Rates UNITED STATES 1st lb. Aiditional

50 miles of Washington, D. C

1 st lb.
or fraction
fraction

50 miles of 150 miles of Trashington,

$\$ 0.05$

$\$ 0.01$

1500 miles of II ashington, $\mathrm{D}$.

.05

.06

.01

$\begin{array}{ll}3 \mathrm{~d} & 150 \text { to } 300 \text { miles of Washington, D. C } \\ 4 \text { th } & 300 \text { to } 600 \text { miles of Washington, D. C }\end{array}$

5th 600 to 1000 miles of Washington, D. C

.07

.02

600 to 1000 miles of Washington, D. C .

.08

.04

Maximum weight, $70 \mathrm{lbs}$. to 1st, $2 \mathrm{~d}$ and $3 \mathrm{~d}$ Zones, and $50 \mathrm{lbs}$. from the 4 th Zone upward.

Postage to Canada, 12 cts. per lb., or fraction thereof, maximum weight, 4 lbs. 6 ozs.

The attention of our customers is respectfully called to the following directions, which will, if followed, be an aid to purchasers as well as ourselves.

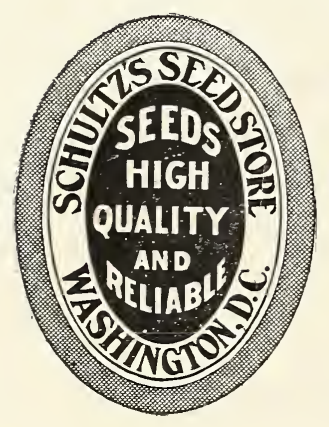

ORDER EARLY. It will greatly facilitate shipments if orders are sent in early. WVe aim to send off all orders the same or next day after receipt, but during the rush season this is impossible-hence the advisability of ordering early.

PRICES AND TERMS. The prices quoted are those ruling at this date, and are Subject to Fluctuation Without Notice. Our terms of payment are Net Cash.

REMITTANCES should be made by Post Office Money Orders, Drafts on Washington Banks, or Express Money Orders. We disclaim all responsibility when remittances are not made as above directed. Where it is not possible to obtain these, the letter should be registered. Postage stamps will be found a convenient method of remitting for small amounts, and can be used by us to advantage. Coin should not be sent by mail. We must decline sending goods C. O. D.

ACCOUNTS. Parties having no account with us-who order goods without remittance-must furnish satisfactory reference. Washington City reference preferred on account of the shorter delay pending investigation.

WE DELIVER FREE IN THE UNITED STATES to any Post Office, Railroad Express Office or Station, at our option, all Vegetable and Flower Seeds at the packet, ounce, and 1/4-pound prices. Purchaser pays transit charges on pints, quarts, pecks, bushels; also Farm Seeds, Bulbs, Plants, Tools, Fertilizers, Insecticides, etc. If pints and quarts of Peas, Beans and Corn are wanted, post or express paid, please remit extra.

BAGS AND PACKING. No charge for boxes or packing, nor for delivery to Freight Depots or Express Offices. Cotton and Burlap Bags we charge for at cost, and if returned in good condition free of expense, they will be credited as charged.

CHANGES OF RESIDENCE. In order that our Catalogues may be forwarded regularly, we will feel obliged if Customers inform us of any change of residence. To any Customer who may fail to receive a Catalogue at the usual time, we will gladly send another copy on receipt of a postal card.

QUOTATIONS with samples will be cheerfully given for such variable articles as Grasses and Clover Seeds.

ERRORS. We exercise the utmost care in filling, checking and packing orders; yet, in the press of business, errors sometimes occur, in which event we wish to be promptly notified of the fact and will make such corrections as will be satisfactory. Please keep copies of all your orders for comparison.

WE CANNOT GUARANTEE THE SUCCESS of any seeds, plants or bulbs we send out. Most of the failures are due to causes entirely beyond our control, such as unfavorable weather or soil conditions, tco deep or too shallow planting, etc., which renders it impossible for us to guarantee success, and although we take all possible care to supply only such goods as will, under proper conditions, produce satisfactory results, we will not be in any way responsible for the crop, and every order for articles named in this catalogue will be executed on these conditions only. It must, however, be plain to everyone who gives the matter the slightest thought, that it is to our best interests to send out only such stock as will not only grow but prove true to name and description.

NON-WARRANTY. Schultz's Seed Store give no warranty, express or implied, as to description, quality, productiveness or any other matter of any seeds, bulbs or plants we send out, and we will not be in any way responsible for the crop. If the purchaser does not accept the goods on these terms they are at once to be returned. 


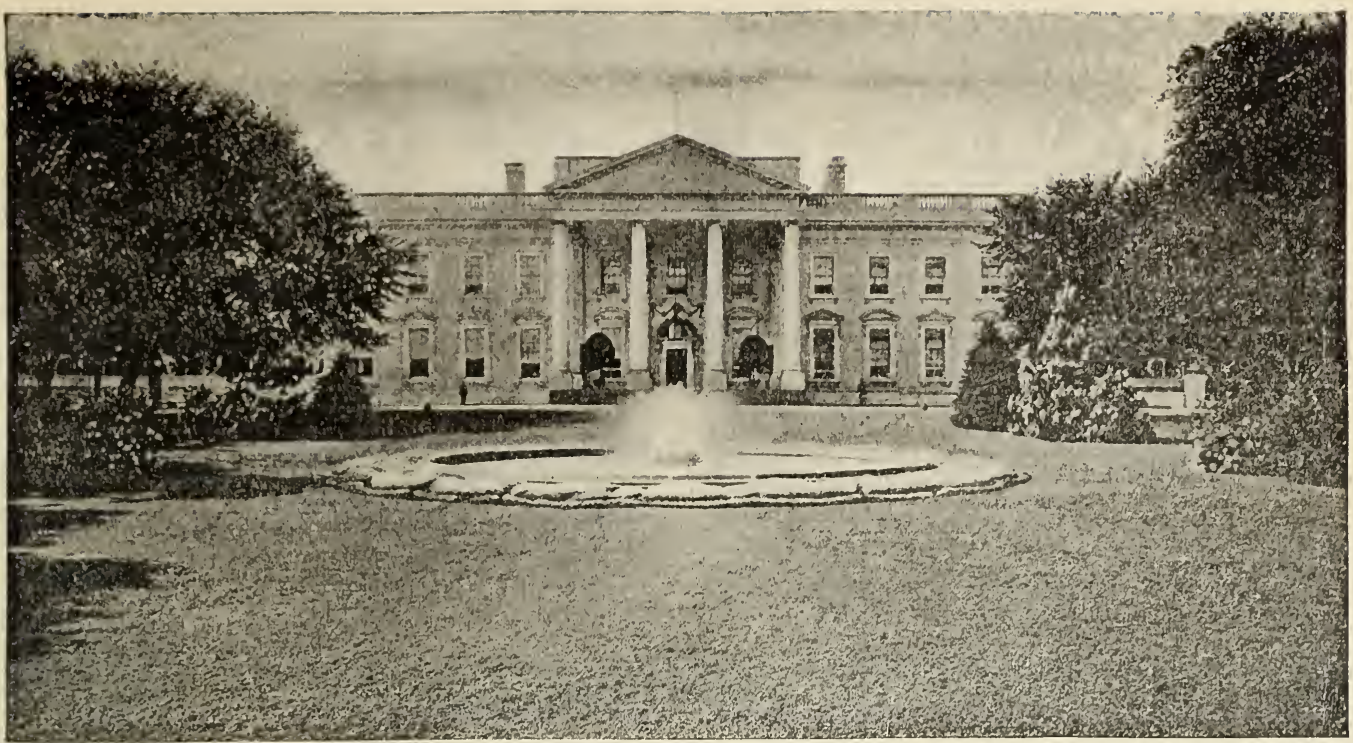

\section{Schultz's \\ White House Lawn Grass Mixture}

\section{FREE FROM CHAFF, WEEDS AND FOREIGN MATTER SOLID, CLEAN SEED ONLY}

"Schultz's White House" Lawn Grass is a mixture of the finest American and European "Schultz's White House" Lawn Grass grasses adapted to lawn making. The formula for this mixture is the result of life-time practical experience in making and maintaining lawns. Neither pains nor expense are spared in obtaining grasses of high vitality and purity. It is our constant aim to make "White House" Lawn Grass the best, purest and most permanent Lawn Grass sold.

One quart will sow 300 square feet. Price per quart, 30c.

Two quarts will sow 600 square feet. Price 55c.

Four quarts will sow 1200 square feet. Price $\$ 1.00$.

One peck will sow 2400 square feet. Price $\$ 1.65$.

One bushel (14 lbs.) will sow 5600 square feet. Price $\$ 4.00$.

"Schultz's White House" Lawn Grass Seed produces a perfect and ant richness, with closely interwoven, firm, deep and elastic turf, and it is often ready for cutting in four weeks from time of sowing. This celebrated Lawn Grass is composed of a thoroughly balanced combination of various native and foreign fine-leaved, deep-rooting grasses of interweaving habit, that flourish under our varied conditions, soils, and climates, growing during different seasons of the year, so that a deep green, smooth and velvety sward, free from clumps, is maintained from snow to snow, year after year, and without burning brown in Summer.

\footnotetext{
FERTILIZZERS

for the

L a w n

and

Flower Garden

See page 56
}

\section{White or Lawn Clover}

Will succeed almost anywhere in the United States, and on almost any character of soil. It is of dwarf habit, spreads rapidly and is very hardy. A proportion of this White Clover will add much to the beauty of your Lawn, and will green up the bare spots which usually occur. $1 / 4 \mathrm{lb} .25 \mathrm{c} ., 1 / 2 \mathrm{lb} .40 \mathrm{c} ., \mathrm{lb} .75 \mathrm{c} ., 10 \mathrm{lbs} . \$ 7.00$.

\section{Schultz's Grass Seed Mixture for Shady Places}

This is a mixture of extra fine grasses adapted for growing in the shade and under trees. We recommend the use of this mixture wherever other grasses, on account of shade, have failed to make a close sward. Qt. 35c., 2 qts. 65c., 4 qts. $\$ 1.25$, pk. $\$ 1.75$, bus. (14 lbs.) $\$ 4.50$.

\section{Schultz's "Terrace" Lawn Grass Seed}

\section{FOR TERRACES, EMBANKMENTS AND HILLSIDES}

A special mixture of grasses best suited for sowing on terraces, embankments and hillsides; grasses that produce long, strong, spreading roots, thus preventing heavy rains from washing them out; that will withstand drought and exposure, thrive on shallow soils, and at the same time produce a rich, velvety green turf throughout the season. There need be no fear of introducing coarse grasses into your lawn by sowing this mixture, for, though strong rooted, the grasses are equally as fine-leaved as those used in the "White House" Lawn Grass Mixture.

Qt. 35c., 2 qts. 65c., 4 qts. $\$ 1.25$, pk. $\$ 1.75$, bus. (14 lbs.) $\$ 4.50$. 


\section{PLAN FOR KITCHEN GARDEN}

For the convenience of those who have only a limited space at their command, the accompanying plan is suggested as an aid in laying out a small kitchen garden. Where the rows are made the distances apart indicated on this diagram, thirty-five feet are required in one direction.

If the rows are to run east and west it is desirable to have the corn at the north end, otherwise the corn is likely to shade too much the rows near it on the north side.

The rows may be as long as space permits or individual preferences may call for, and where space is less limited, more rows of favorite sorts may be added or provision made for other vegetables or flowers that may be desired.

The Asparagus, Horse Radish and Rhubarb should be permanent beds.

Among the varieties of vegetables that we recommend, are the following:

Tomato.-Earliana, Bonny

Best and Schultz's Early Splendid.

Cabbage, First Early.-Early

Jersey Wakefield and Schultz's Early Market.

Cabbage, Second Early and

Intermediate.-All Head Early,

Early Summer and Succession.

Cauliflower. Early Favorite

and Early Snowball.

Onion.-Silver Skin.

Pepper.-Chinese Giant, Ruby

King and Large Bell or Bull Nose.

The above sorts do best when

started indoors and transplanted.

Others mentioned. below may be sown outdoors.

Lettuce, Clustering or Loose Leaved.-Selesian, or Cut and Come Again and Simpson's Early Curled.

Lettuce, Cabbage Heading.Schultz's Butter Ball, Wayahead and Big Boston.

Onion.-Mammoth Prizetaker,

Yellow Globe Danvers and South-

port White Globe.

Radishes.-Early Scarlet Globe, French Breakfast, Scarlet Turnip, White Tipped, Long White Icicle,

Early Long Scarlet and Crimson Giant.

Spinach.-Early Bloomsdale Savoy and New Zealand.

Parsley.-Schultz's Triple Curled and Champion

Moss Curled.

Asparagus.-Palmetto and Conover's Colossal.

Peas.-Little Marvel, Schultz's Big Marvel and

British Wonder

Beet.-Crosby's Egyptian, Crimson Globe and

Detroit Dark Red.

Corn Early.-Howling Mob, Golden Bantam and

Kendall's Early Giant.

Corn, Main Crop.-Snow White Evergreen,

Country Gentleman and Stowell's Evergreen.

Beans, Dwarf Green Podded.-Stringless Green

Pod and Early Red Valentine.

Beans, Dwarf Wax Podded.-Golden Wax and

Sure Crop Stringless Thax.

Beans, Pole.-Kentucky Wonder and Horticultural Cranberry.

Even a small yard should have its flowers. Plant a few Sweet Peas or some Nasturtiums, either Dwarf or Trailing. Our mixtures of Asters, Pansies, Petunias, Phlox Drummondi, Poppies, Morning Glories, Marigolds, Verbenas and Zinnias, all are easily grown. A few packets of flowers well grown will give an abundant harvest of pleasure.

Each packet of seed gives cultural directions sufficient to insure success under normal conditions, and more detailed suggestions for many sorts will be found in the following pages.
Beans, Bush Lima.-Fordhook and Burpee's Improved.

Beans, Pole Lima.-Schultz's Early Market and

Curpee's Giant Podded.

Cucumber.-Schultz's Evergreen and Arlington White Spine.

Squash, Summer.-Benning Bush and Yellow ummer Crookneck.

Squash, Fall and Winter.-Prolific and Hubbard.

Musk Melon.-Emerald Gem, Sweet Air and Money Maker.

Watermelon.-Monte Cristo and Florida Favorite.

Carrot.-Danvers and Rubicon.

Parsnip.-Perfect Hollow Crown.

Salsify.-Mammoth Sandwich Island.

Kale.-Schultz's Imperial Curled.

Swiss Chard.-Giant Lucullus.

Cabbage, Fall and Winter.-Schultz's Large Late Flat Dutch.

Turnip.-Purple Top White Globe, Extra Early Milan and Purple Top Strap Leaf.

Potatoes.-Irish Cobbler, Early Rose and Green Mountain. 


\section{A LIST OF VEGETABLE SEEDS THAT CAN BE SOWN IN EACH MONTH, FROM FEBRUARY TO SEPTEMBER}

FEBRUARY.-Sow in hotbed: Early Beets, Early Cabbage, Forcing Carrot, Early Celery, Cucumber, EggPlant, Early Lettuce, Parsley, Pepper, Radish, Tomato.

MARCH.- - Sow in hotbed: Beans, Early Beets, Brussels Sprouts, Early Cabbage, Forcing Carrot, Cauliflower, Celery, Cucumber, Egg-Plant, Kohl-Rabi, Lettuce, Melon, Onion Sets, Parsley, Peas, Pepper, Radish, Tomato.

Sow in open ground: Beets, Carrot, Cress, Leek, Onion, Peas, Potatoes, Radish, Spinach, Early Turnip, Sweet Peas.

APRIL.-Sow in hotbed: Cucumber, Egg-Plant, Melon, Pepper, 'Tomato.

Sow in open ground: Asparagus, Beans, Beets, Brussels Sprouts, Early Cabbase, Carrot, Cauliflower, Celery, Cress, Endive, Kale, Kohl-Rabi, Leek, Lettuce, Onion, Onion Sets, Parsley, Parsnip, Peas, Potatoes, Radish, Spinach, Early Turnip, Sweet Peas.

MA Y.-Artichoke, Asparagus, Beans, Beets, Brussels Sprouts, Late Cabbage, Carrot, Cauliflower, Celery,
Sweet Corn, Cress, Cucumber, Endive, Kale, Kohl-Rab1, Leek, Lettuce, Melon, Onion, Farsiey, Karsnip, Peas, Potatoes, Radish, Rhubarb, Salsify, spinach, 'Tomato, Early 'Turnip, all' Herbs.

JUNE.-Beans, all kinds; Beets, Brussels Sprouts, Early Cabbage, Carrot, Cauliflower, Sweet Corn, Cress, Cucumber, Endive, Kale, Kohl-Rabi, Lettuce, Melon, Nasturtium, Okra, Early Peas, Potatoes, Pumpkin, Radish, Salsify, Spinach, Squash, Herbs.

JULY.-Beans, Beets, Carrot, Sweet Corn, Corn Salad, Cress, Cucumber, Endive, Gherkin, Kale, Kohl-Rabi, Lettuce, Nasturtium, Okra, Early Peas, Potatoes, Pumpkin, Radish, Salsify, Spinach, Squash, Herbs.

AUGUST.-Beans, Bush; Corn Salad, Cucumber, Endive, Kale, Lettuce, Early Peas, Radish, Spinach, Turnip.

SEPTEMBER.-Cabbage for coldframes, Cauliflower for coldframes, Cabbage, Corn Salad, Cress, Onion Sets, Kale, Lettuce, Mustard, Winter Radish, Spinach, Turnip, Sweet Peas.

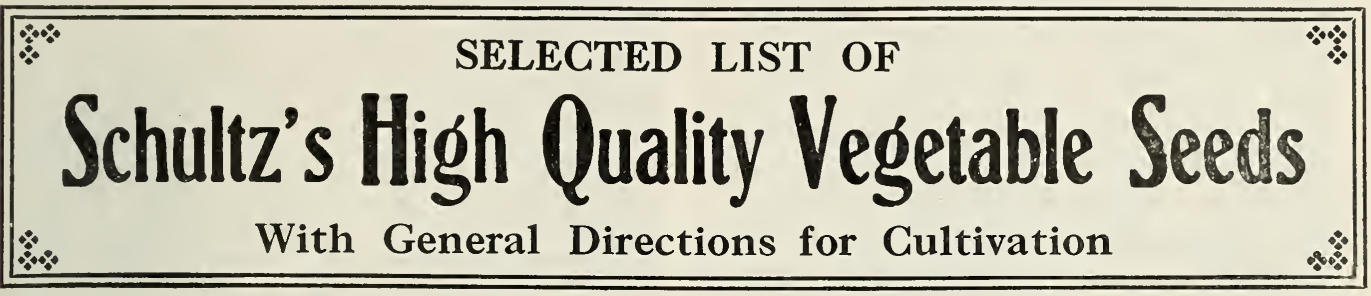

\section{ARTTCHOFF Artichaut, Fr.}

One ounce will produce 500 plants.

Cuiture.-Sow seed in hotbed in February or March in rows 6 inches apart. Transplant when large enough into boxes or pots. After danger of frosts is past plant in the open ground, in rows 3 feet apart, 2 to 3 feet apart in row, care being taken to press firmly in the ground, but not planted too deep.

Large Globe, or Paris. The best of all Artichokes. Pkt. 5c., oz. 35c.

Jerusalem Artichoke. Distinct from the Globe, and propagated by and for its tubers. Largely used for feeding stock. Pk. 75c., bus. $\$ 2.50$.

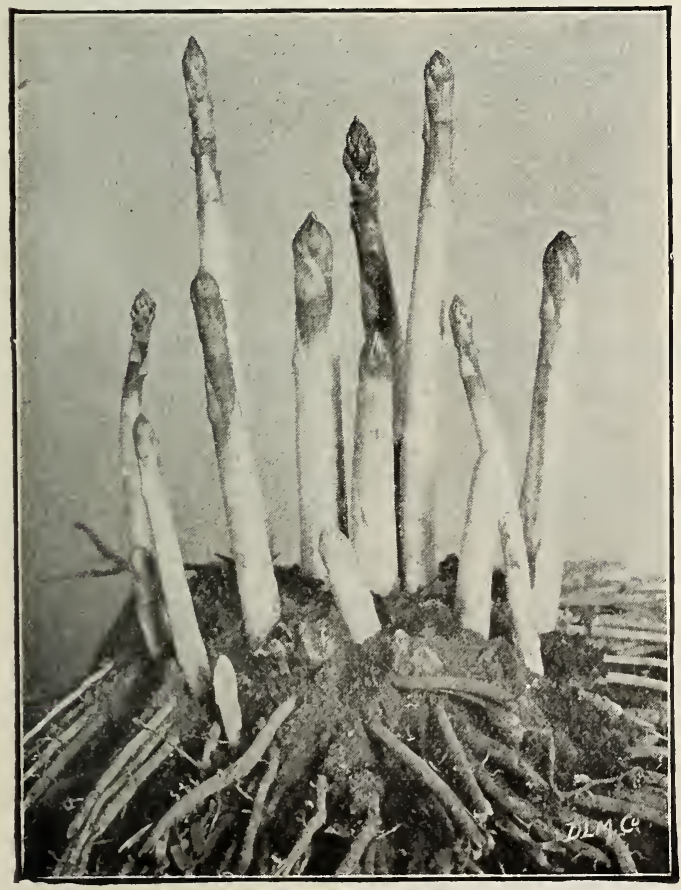

Palmetto Asparague
ASPARAGUS

One ounce will sorv about 50 feet of drill; 4 to 5 pounds per acre

Culture.-Sow the seed as early in Spring as the soil can be worked, in drills 12 inches apart, and when well started thin out to 3 inches apart. When one or two years old, transplant into permanent keds, which should be well and deeply manured and trenched to a depth of 18 inches. Set the plants in rows 2 feet apart, and not less than 18 inches apart in the row. Care should te taken that the roots are well spread, and set at a depth of 6 inches below the level of the bed. Cover only 2 or 3 inches, and fill in gradually as the plants grow. Very little, if any, should be cut the first year after transplanting, but a fair crop can be cut the second year. Every Fall after the tops have been cut down apply a dressing of coarse manure, and in the Spring fork it in. An occasional top dressing of kainit at the rate of one half pound per square yard is also beneficial.

Conover's Colossal. The standard variety, large and very prolific. Pkt. $5 \mathrm{c}$. and $10 \mathrm{c} ., \mathrm{oz} .15 \mathrm{c} ., 1 / 4 \mathrm{lb}$. 25c., lb. 65c.

Argenteuil. This variety is largely grown in France for the Paris market. Pkt. 5c. and 10c., oz. 15c., $1 / 4$ lb. $25 \mathrm{c} .$, lb. $75 \mathrm{c}$.

Palmetto. An early, prolific and very desirable variety. Pkt. 5c. and 10c., oz. 15c., 1/4 lb. 25c., lb. $75 \mathrm{c}$.

Barr's Mammoth. A quick grower with very large stalks. Pkt. 5c. and 10c., oz. 15c., 1/4 lb. 25c., 1b. 65c. Columbian Mammoth White. Large, white stalks. Pkt. 5c. and 10c., oz. 15c., 1/4 lb. 25c., lb. 75c.

\section{ASPARAGUS ROOTS}

Extra strong and healthy roots. Two years old.

$A$ bed $12 \times 35$ would require about 150 roots. About 2500 roots are required to plant an acre.

Palmetto. Per 2575 c., $100 \$ 1.50,1000 \$ 10.00$.

Columbian Mammoth White. Per 25 75c., $100 \$ 1.50$ $1000 \$ 10.00$.

Conover's Colossal. Per 25 75c., $100 \$ 1.50,1000$ $\$ 10.00$.

Giant Argenteuil. Per 25 75c., $100 \$ 1.50,1000 \$ 10.00$

Barr's Mammoth. Per 25 75c., $100 \$ 1.50$, $1000 \$ 10.00$. 


\section{BEANS}

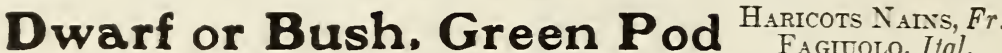

\section{If wanted by mail, add, for postage. One quart will plant 100 feet of rove.}

Culture.-The varieties of this class are tender and will not bear much cold. Plant about the first of April if the ground is warm and the season favorable, and at intervals throughout the season for a succession, finishing about the 15th of August. The best mode of culture is in rows, 2 feet apart, and the beans 2 inches apart, and 2 inches deep in rows. Keep well hoed and draw the earth up to the stem, but only when dry; working them when rill cause them to rust and injure the crop.

Schultz's Stringless Green Pod A new early variety. The plant is of true bush habit and bears an enormous quantity of handsome pods of light green color. They are brittle, tender, fieshy and absolutely stringless, eren when fully matured. High quality, stringlessness and productiveness should be sufficient to recommend this Bean to erery planter. Pkt. 10c., pt. 30c., qt. 50c., 4 qts. $\$ 1.60$, pk. $\$ 3.00$, bus. $\$ 10.00$

Burpee's Stringless Green Pod Posistringless; ripens earlier than Valentine, and remains tender and crisp a long time after maturity. Pods are pale green, long and straight, perfectly round and meaty. Pkt. 10c., pt. 30c., qt. 50c., 1 qts. $\$ 1.60$, pk. $\$ 3.00$, bus $\leqslant 10.00$

Valentine Improved Early Red

For snaps there is nothing superior to this rariety among the green-podded sorts, and many prefer it to the wax varieties. Vine erect, with coarse, dark green leaves. Pods medium length, curred, cylindrical, very fleshy, crisp and tender. We know of no stock of Red Valentines which can be compared with that we offer in uniformly high quality of pod. Pkt. 10c., pt. 30c., qt. 50c., 4 qts. $\$ 1.50$, pk. $\$ 2.50$, bus. $\$ 9.00$.

King of the Earlies This rariety can be earlier than any other green Bean; as the dry Bean will stand considerable cold, wet weather, while other varieties at the same time, will rot in the ground. The main feature of this Bean is its earliness. The pods are usually ready to pick at least 5 days ahead of Red Valentine, and are a beautiful green color, extra long, almost straight, round, thick, meaty, tender and in flaror unsurpassed. Pkt. 10c., pt. 30c., qt. 50c., 4 qts. $\$ 1.50$, pk. $\$ 2.50$, bus. $\$ 9.00$.

Black Valentine Pods are extremels long, are quite attractire in appearance. Pkt. 10c., pt. 30 c., qt. 50c., 4 qts. $\$ 1.50$, pk. $\$ 2.50$, bus. $\$ 9.00$,

Longfellow A very productire, early green6 inches long, medium light green in color, tender, of excellent quality, and quite stringless when young. One of the most at tractive market sorts. Pkt. $10 \mathrm{c}$., pt. 30c., qt. 50c., 4 qts. $\$ 1.50$, pk. $\$ 2.50$, bus. $\$ 9.00$. Bountiful, Henderson's An extra-early of fine table qualities. It is rery hardy, extremely early, very prolific, and bears continually for sereral weeks. The pods are thick, broad, extra long, rery

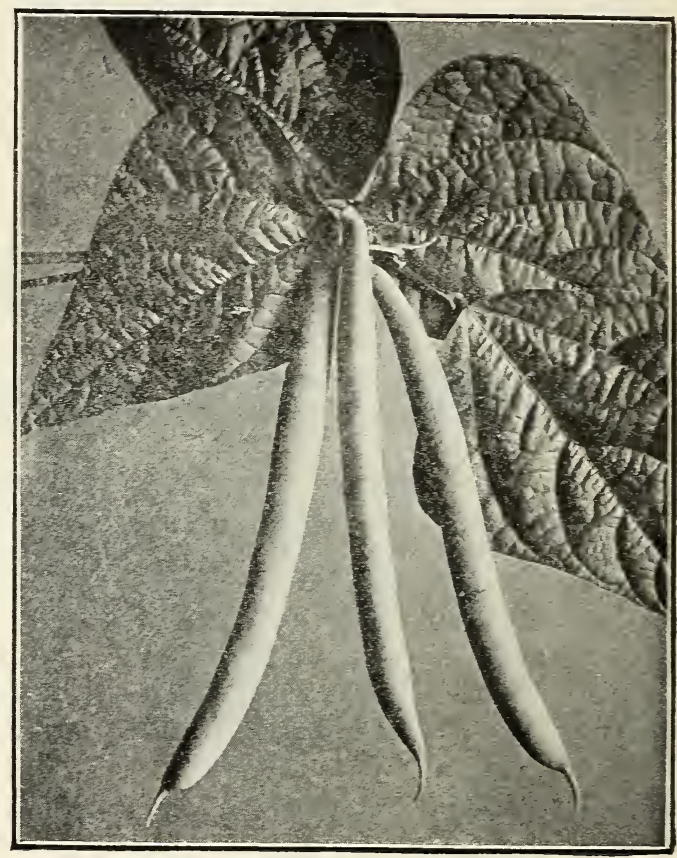

Burpee's Stringless Green Pod Bean

market. Pkt. 10c., pt. 30c., qt. 50c., pk. $\$ 2.50$, bus. $\$ 9.00$.

Full Measure A rery desirable round-podded, rariety with pods 6 to 7 inches solid, meaty, brittle and stringless. It is a little later than Stringless Green Pod, and is a splendid Bean for home or market use. Pkt. 10c., pt. 30c., qt. 50c., 4 qts. $\$ 1.50$, pk. $\$ 2.50$, bus. $\$ 9.00$.

Dwarf Horticultural vine very productive, with large leares. Pods medium length, cylindrical, curved with splashes of bright red on a yellowish ground. Pkt. $10 \mathrm{c} .$, pt. $30 \mathrm{c} .$, qt. 50c., 4 qts. $\$ 1.50$, pk. $\$ 2.50$, bus. $\$ 9.50$.

Boston Pea Bean (Nary). An excellent rariety of rery productive habit; for baking they excel all other sorts. Plt. $10 \mathrm{c} .$, pt. $30 \mathrm{c}$., qt. 50c., 1 qts. $\$ 1.50$,
pk. $\$ 2.50$, bus. $\$ 9.00$.

\section{BEANS - Running, or Pole}

Kentucky Wonder Also known as Old liere this rariety is the most practically useful of the green-podded pole beans suitable for use as snaps. It is an early, very prolific sort, with showy pods which are of most excellent quality. The vines are vigorous, climbing well and very productive, bearing pods in large clusters. Pkt. 10c., pt. 30c., qt. 50c., pk. $\$ 3.00$, bus. $\$ 11.00$

Horticultural Cranberry (Cutshort.) best for family use. The pods are tender, and of fine quality. Pkt. 10c., pt. $30 \mathrm{c} .$, qt. 50c., pk. $\$ 3.00$, bus. $\$ 10.00$.
Kentucky Wonder Wax This rigorous bean is very similar to the green-podded Kentucky Wonder but the pods are a little broader. They are very fleshy and stringless as snaps and are of excellent quality. The pods are rery-long, handsome light yellow, often $\delta$ to 9 inches in length. Pkt. 10c., pt. 35c., qt. 60c., pk. $\$ 3.00$.

Golden Cluster Wax. Long, golden-yellow pods borne in clusters: extra early, stringless, snaps easily, vigorous, prolific, tender. Pkt. 10c., pt. 35c., qt. $65 \mathrm{c}$. pk. $\$ 3.50$.

Lazy Wife A white-seeded variety, with long, qt. 65 c., pk. $\$ 4.00$. 


\section{BEANS-Dwarf or Bush, Wax Podded}

Kidney Wax, Burpee's Longer pods and IVardwell's more prolific than stringless, more fleshy. The foliage is free from blight, while the pods are rust-proof. The pods are 7 inches in length, one-half inch broad and threeeighth inch thick; the color is a rich, lemon yellow. Pkt. 10c., pt. 35c., qt. 60c., 4 qts. $\$ 2.00$, pk. $\$ 4.00$, bus. $\$ 12.00$.

Black Wax, Improved Prolific One best for a home garden, perfectly stringless, and of excellent flavor. Pods nedium size, round and of clear, waxy white color. Pkt. 10c., pt. 35c., qt. 60c., 4 qts. $\$ 1.75$, pk. $\$ 3.00$, bus. $\$ 10.00$.

\section{Refugee Wax, Keeney's Stringless}

This new variety of dwarf 11 ax Bean is an improved type of the Refugee Wax. The plants are of very robust growth and extremely early and productive, bearing profusely the large, beautiful pods which are of delicious flavor. The pods are round, pencillike. The color is a rich golden yellow and the quality is excellent. Pkt. 10c., pt. 35c., qt. 60c. 4 qts. $\$ 1.75$, pk. $\$ 3.00$, bus. $\$ 10.00$.

Kidney Wax, Wardwell's One of themost in this vicinity, especially for the market gardener, owing to the large size of the pod and excellent quality.

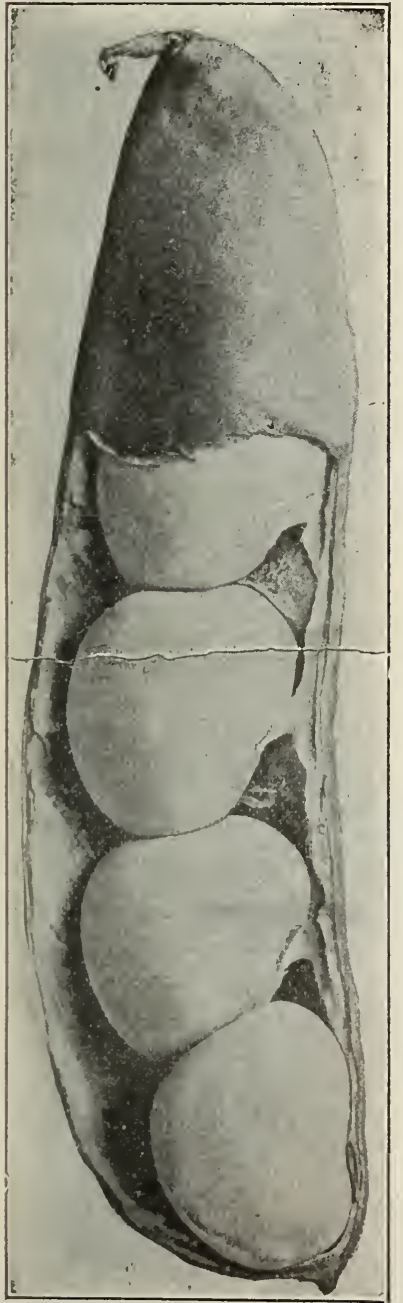

Burpee's Fordhook Bush Lima of the

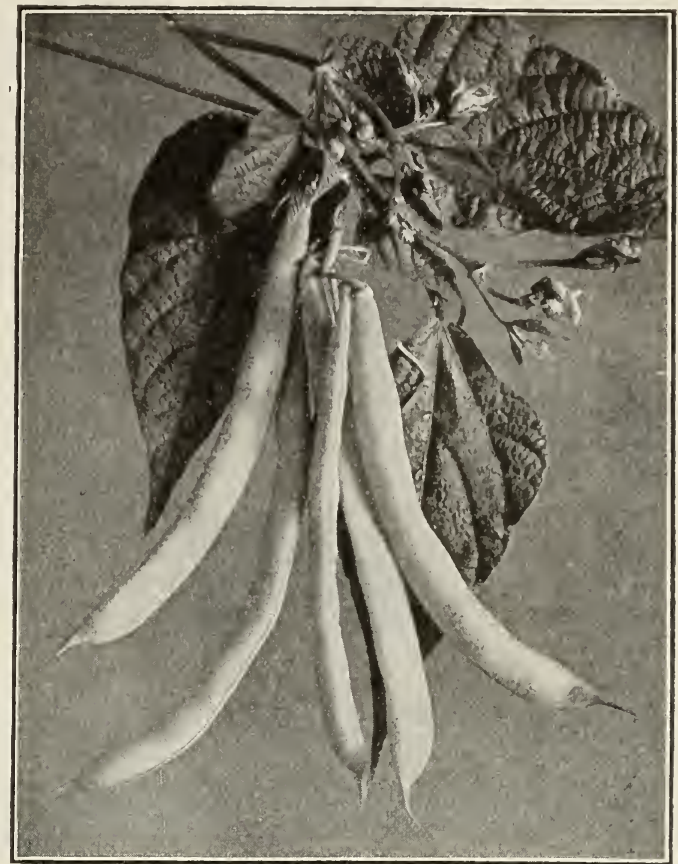

Stringless Golden Wax Beans beans are large, kidney - shaped, white, d a r kmarked about the eye. Pkt. 10c., pt. 35c., qt. 63c., 4 qts. $\$ 2.00$, pk. $\$ 3.50$, bus. $\$ 12.00$

Sure Crop Stringless Wax A valuable new variety for either home use or market garden. Is a dwarf growing variety; strong vigorous vines, producing early, rich vellow pods of extra size, measuring 7 to $71 / 2$ inches long, more than 1 inch wide, and nearly $1 / 2$ an inch thick, of excellent quality; stringless and tender at all stages of its development. Plant is strong and holds pods well off the ground and will stand long seasons of wet weather. Because of its being very hardy the seeds may be planted early. Plt. 10c., pt. 35c., qt. 65c., 4 qts. $\$ 2.25$, pk. $\$ 4.00$, bus. $\$ 13.00$.

Golden Wax, Keeney's Stringless $\begin{gathered}\text { A vigorous and wonderfully } \\ \text { productive Bean of excellent }\end{gathered}$ quality. The pods are thick, meaty entirely stringless and tender. The plant throws out long, pod-bearing tendrils, which appear at first like runners, but it is a true bush Bean. We recommend it very strongly for its productiveness and fine quality. Pkt. 10c., pt. 35c., qt. 60c., 4 qts. $\$ 2.00$, pk. $\$ 3.00$, bus. $\$ 10.00$

Hardy Wax An early round-podded sort, very productive; perfectly Hardy stringless. and most desirable for the home garden. Pkt. 10 c., pt. 35 c., qt. 65 c., 4 qts. $\$ 2.00$, pk. $\$ 3.50$, bus. $\$ 12.00$.

\section{LIMA BEANS-Bush Varieties}

One quart will plant about 150 hills, or 100 feet of row.

Plant in light, rich soil in drills 2 feet apart, dropping the seeds about 1 foot apart in the row, and cover 2 inches.

Fordhook This is altogether unique. Nothing like it has ever been seen popular. Potato Lima. Both pods and beans are twice the size of Dreer's and more than half again as large as the Challenger Pole Lima. Pkt. 10c., pt. $45 \mathrm{c}$, qt. $80 \mathrm{c} ., 1 / 2$ pk. $\$ 2.75$, pk. $\$ 5.00$, bus. $\$ 18.00$.

Burpee's Improved The luscious, green beans are larger than any Burpee's Improved Limas ever known before. It is fully eight to ten days earlier than any other large Limas, will outyield Burpee's Bush Lima by fully one-third, as the pods are very much larger, while the beans either green or dry, are nearly twice as thick. Pkt. 10c., pt. 45c., qt. 80c., 4 qts. $\$ 2.75$, pk. $\$ 5.00$, bus. $\$ 18.00$.

Dreer's This valuable bush Bean possesses all the good qualities of the pk. $\$ 5.00$ Dreer's Pole Lima. Pkt. 10c., pt. 45c., qt. 80c., 1/2 pk. $\$ 2.75$,

Henderson's This is the small-podded very early Sieva, or Butter Bean pthe South, growing in compact bush form. Pkt. 10c. pt. 35c., qt. 60c., $1 / 2$ pk. $\$ 2.00$, pk. $\$ 3.60$, bus. $\$ 13.00$ 


\section{LIMA BEANS-Pole Varieties}

HaRicots a RAMES, Fr.

One quart will plant 100 hills.

Culture.-These require poles $\delta$ to 10 feet long. The Beans should be planted the middle of May, if the season is suitable. Lima Beans are apt to rot if planted too early. Set poles 4 feet apart each way, and plant four to six Beans about 1 inch deep, around each pole. Thin out to three plants to a pole, if the soil is rich; pinch off the ends of the plants when they orerrun the top of the poles to effect more perfect growth below. They succeed best in sandr loam, with a shovelful of rich, light and well-rotted compost to each hill, well incorporated. Lima Beans for early use may be grown in frames and transplanted.

Schultz's Early Market One week earlier than any other Pole Lima and two weeks earlier than chultz's Early Market most. Of superior quality, immense size. wonderfully productire. One of the best rarieties of Pole Lima for general use. This delicious vegetable is denied many would-be growers or account of the length of season required to mature it, the early frost coming on just as the crop is ready to pick. This sort is at least one week earlier than any-large Pole Lima ret offered and fully two weeks earlier than most. consequently it will prove a boon to thousands of growers. Earliness is often obtained at the sacrifice of other valuable features, but in this variety we claim superiority, not only in this respect, but in size of bean and pod and enormous productireness. It is, in fact, about perfect and of incalculable ralue. Pkt: jc. and 10c., pt. 40c., qt. 70c., pk. $\$ 4.50$, bus. $\$ 16.00$

Burpee's Giant-Podded The lägest podded and heariest cropper of all Lima Beans. The pods are The ly gientic in size, frequently by $1^{1} 2$ to nearly 2 inches in width. The beans are extra large and thicker than any other Pole Lima, excepting only those of the Potato Lima trpe: they are invariably of finest flavor. Burpee's Giant-Podded excels all other Limas in rigor of growth. The vines grow so rapidly that they quickly cover the poles. In rich ground we would recommend planting only two or three seeds to a hill and thinning out co one plant. The pods, borne in clusters of from four to eight, stand out trell from the foliage. Pht. jc. and 10c., pt. $40 \mathrm{c}$., qt. $70 \mathrm{c}$., pk. $\$ 1.50$, bus. $\$ 16.00$.

Carolina Sieva, or Butter This very early and reliable small-seeded Carolina Sieva, or Butter Pole Lima is especially adapted for planting in the South. The rines are vigorous. with many short branches. The leares are small, smooth, stiff, glossy dark green. The pods are dark green. short, about 3 inches, curved, flat. seed small, flat, white with slight tinge of rellow. This is sometimes called Sewee. It is the most generally known "Butter Bean" of the South. Pkt. 5c. and 10c., pt. 35c., qt. 60c., gal. $\$ 2.25$, pk. $\$ 1.00$, bus. $\$ 14.00$

King of the Garden A rigorous grower, bearing large pods, varsing in length from 5 to $s$ inches. The beans are large bus. $\$ 15.00$

Early Leviathan It will not only give large Lima Beans earlier than any early and throughout the season. It is a strong grower, clinging well to the poles, and is a sure cropper. Pkt. 5 c. and $10 \mathrm{c} .$, pt. $35 \mathrm{c} .$, qt. $60 \mathrm{c}$., gal. $\$ 2.25$, pk. $\$ 4.00$, bus. $\$ 15.00$

Carpinteria The beans of this splendid Pole Lima have a greenish tint, an indication of good quality and an adrantage in appearance orer the white-skinned rarieties. Vines are vigorous and make strong growth, producing large quantities of pods, containing four large beans which are thicker than the ordinary Limas and retain their color eren when in the drv state. Pkt. 5 c. and $10 \mathrm{c} .$, pt. $35 \mathrm{c}$., qt. $60 \mathrm{c}$., gal. $\$ 2.25$, pk. $\$ 1.00$, bus. $\$ 15.00$.

\section{BRUSSELS SPROUTS}

Chot de Bruxelles, Fr.

Catolo di Brésselles, Ital.

Culture.-A species of the Cabbage family which produces miniature heads from the sides of the stalk. These heads are of great delicacy, boiled in the same may as Cauliflower. The seeds should be sown about the middle of Mar, in a seed bed, and the plants afterward set in rows 2 feet or more apart, and cultivated like Cabbage. This regetable does not require extremely high cultiration, howerer. It is ready for use late in Autumn, after the early frosts.

Long Island Improved The finest variety; of rigorous growth, and Long Island Improved producing handsome. solid, round sprouts of the best quality. Pkt. 5c. and 10c., oz. 40c., 1/4 lb. $\$ 1.25$, lb. $\$ 4.00$.

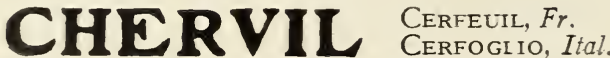
Curled Cultivated the same as Parsley. The leares are used for flaroring
soups and stews, and for garnishing. Pkt. 5c., and 10c., oz. 20c.,

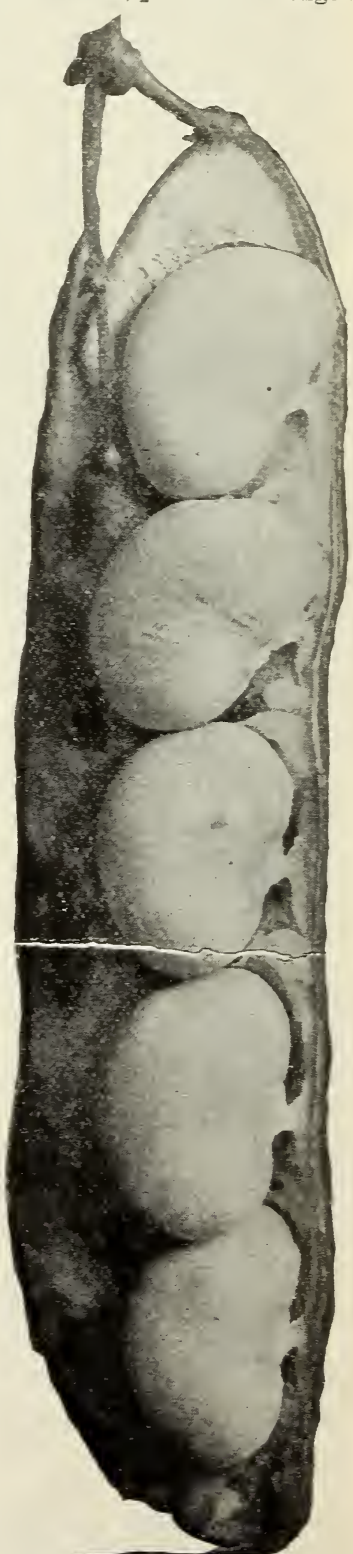

Schultz's Early Market Pole Lima 


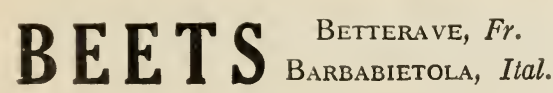

One ounce will sow 50 feet of drill; 5 to 6 pounds to an acre.

Culture.-Sow as early in the Spring as the ground can be worked, and every two weeks after for a succession up to the end of July. For general crop, sow about the middle of May The soil should be light, sandy loam, well enriched with stable manure, and plowed and harrowed until very fine. Sow in drills 1 foot to 15 inches apart, when well up, thin from 4 to 6 inches.

Extra Early Model Extremely early, Extra Early Modect globe form and finest quality. The foliage is very suall. The beets are always smooth and of the deepest blood-red color, while they quickly attain a good size. Pkt. 5c. and 10c., oz. 15c., ${ }_{1}+1$ lb. 35c., lb. $\$ 1.00$.

\section{Crosby's Improved Egyptian}

Very early. Smooth, globe-shaped. Dark blood red. One of the best for planting early out of doors. It becomes fit for use sooner than any other variety, and is equally suited for forcing in hotbeds or for transplanting. Pht. 5c. and 10c., oz. 15c., $1 / 4$ lb. 35c., lb. $\$ 1.00$.

Crimson Globe An extremely handcrop variety, of medium size, almost globeshaped, and entirely free from rootlets, leaving the skin entirely smooth. The roots average 10 inches in circumference, the foliage is small and of a rich, bronze purple. The flesh is a rich blood red, slightly zoned, and of the finest quality, always sweet and tender, never stringy. Pkt. 5c. and $10 \mathrm{c}$., oz. 15c., $1 / 4$ lb. 35c., lib. $\$ 1.00$.

Eclipse, Extra Early $\begin{aligned} & \text { Handsome, smooth, } \\ & \text { dark, round-shaped }\end{aligned}$ Beet. Small top and of excellent table qualities. Makes an attractive seiler in market. Pkt. 5c. and $10 \mathrm{c}$, oz. $15 \mathrm{c}$., $1 / 4 \mathrm{lb}$. 35c., lb. $75 \mathrm{c}$.

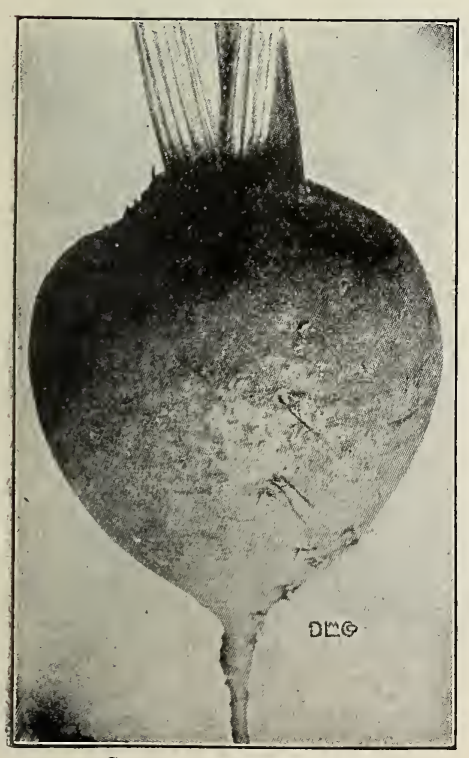

Crimson Globe Beet
Bastian's Early Blood Turnip. Of quick and large growth, bright red color; beautiful form and delicious flavor. Pkt. 5c. and 10c., oz. 15c., $1 / 4$ lb. 35c., lb. $\$ 1.00$.

Edmand's Early Blood Turnip of beautiful, round form dark red and of finest quality. Pkt. $5 \mathrm{c}$. and $10 \mathrm{c}$., oz. $15 \mathrm{c} ., 1 / 4 \mathrm{lb}$. 35c., lib. $7 \overline{5}$ c.

Long Smooth Blood. An excellent, dark-fleshed main crop sort. Very tender and sweet, and remaining so when they are kept until Spring. Pkt. 5c. and 10c., oz. 15c., $1 / 4$ lb. 35c., lb. $\$ 1.00$.

Dewing's Blood Turnip. Of fine form and flavor, and deep, blood-red color. Pkt. 5c. and 10c., oz. 15c., $1 / 4$ lb. 35c., lb. $\$ 1.00$.

Half-Long Blood. A distinct variety, excellent for Winter use. Pkt. 5c. and 10c., oz. 15c., $1 / 4$ lb. 35c., lb. $\$ 1.00$.

Swiss Chard Sow a row of Swiss Chard; it is delicious. Is cultivated for its leaf stock which is served up like to produces. Will continue 作 regular garden Beets. Pkt. 5c. and 10c., oz. 15c., 1/4 lb. 35c., lb. $\$ 1.00$.

\section{Selected Mangel Wurzels}

Six pounds of seed will sow an acre.

An invaluable crop for stock feeding. Sow from April to June on wellcultivated, deep, rich soil in drills 24 to 30 inches apart.

Mammoth Long Red The largest and heaviest cropper of and distinct variety and very popular on account of its nutritious and milk-producing qualities. 1/4 lb. 20c., lb. $50 \mathrm{c}$.

Giant Golden Tankard. Flesh bright golden yellow, differing in this respect from all other varieties which cut white. $1 / 4 \mathrm{lb}$. 20c., 1b. $50 \mathrm{c}$. 


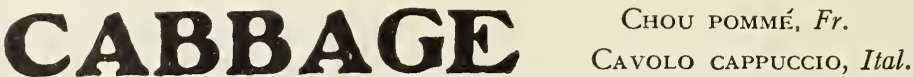

One ounce of seel produces about 2000 plants.

Culture.-For very early use sow in January or February in hotbeds; prick out when plants are strong enough into other hotbeds; or sow in coldframes in March. Transplant to the open ground when danger from killing frost is past, in rows 2 feet apart and 18 inches in row. For succession, sow in open ground the last of March or early in April. The Autumn and Winter varieties sow in April or early in May, in shallow drills, 3 or 4 inches apart; transplant early in July, in rows $2 \frac{1}{2}$ feet apart and 2 feet in the row. Cabbage succeeds best in a fresh, rich soil, well-manured and deeply dug or plowed.

\section{Selected Early Jersey Wake- \\ field The most popular and largely feld grown variety for Fall and early Spring planting. It has pyramidal heads with blunt peaks, is solid, uniform and compact growing. Has small outside foliage and can be planted closer together than the larger varieties. Thorough grown stock, pronounced by our leading truckers and market gardeners as the best stock of Early Wakefield Cabbage on the market. Pkt. 5c. and 10c., oz. $25 \mathrm{c} ., 1 / 4 \mathrm{lb}$. $85 \mathrm{c}$., lb. $\$ 3.00$.}

\section{Charleston, or Large Wake-}

field Large, solid heads of good qualfield ity a few days later than Early Jersey Wakefield; specially recommended for market gardeners, producing fully twice as much per acre as the early variety. The strain we offer is very fine and cannot fail to give satisfaction. Pkt. 5c. and 10c., oz. $25 \mathrm{c}$., $1 / 4$ lb. $85 \mathrm{c}$., lb. $\$ 3.00$.

\section{Schultz's Early Market Is but} four days later than our Early Jersey Wakefield, and will yield a greater crop per acre than any other early Cabbage. T.ue whole plant is well bred. There is an entire absence of coarse veias and leaves, and it has the quality peculiar to some of the best sorts, of hardening the head before it has attained its mature size. The

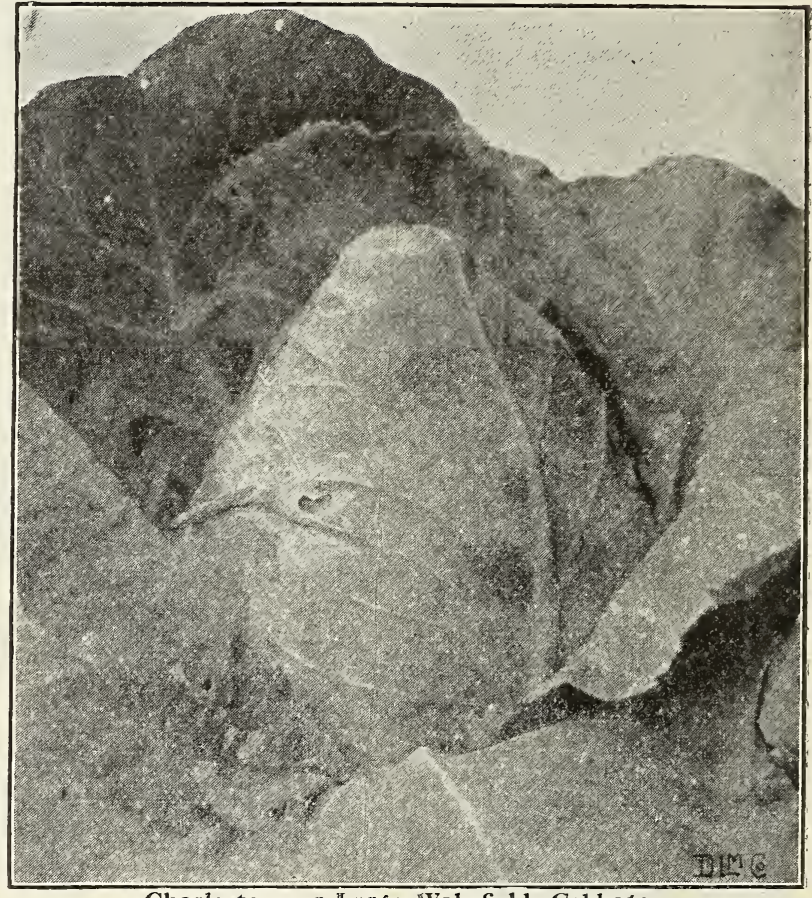

Charle ton, or Large Wakefield Cabbage

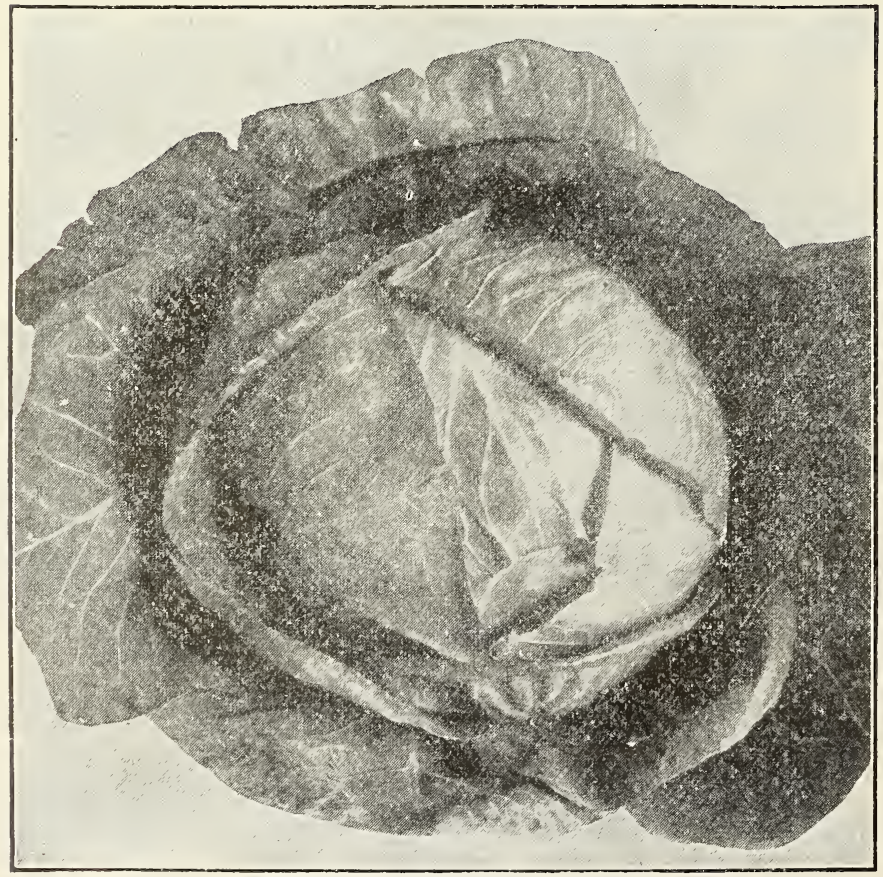

Schultz's Early Market Cabbage plant is small, with short stem, and few outer leaves, which are of rather upright growth; the leaves are medium light green, nearly round, comparatively thick and smooth, and tightly folded. The plants may be set 21 inches apartat least 50 per cent. closer than any variety with a head of similar size. Pkt. 5c. and 10c., oz. 50c., $1 / \mathrm{lb}$. $\$ 1.50$, lb. $\$ 5.00$.

Copenhagen Market The est larme round-headed cabbagearlifered today. It is as earli as Early Jersey Wakefield, heads perfiectly round and very solid. It is very compact in habit, and can be plarted as close as Wakefield. The heads all mature at one time, and will stand before bursting. Heads average about eight pounds each. Pkt. 10c., oz. 30c., 1/4 lb. 85 c., lb. $\$ 3.30$.

\section{Burpee's All-Head Early}

A large, flat-headed early variety; comes in earlier than Eariy summer, and is considerably larger. Feads are of good shape, uniform in size very hard and heavy. Pkt. $5 \mathrm{c}$. and $10 \mathrm{c}$., oz. 3 Jc., $1 / 4$ lb. 85c., lb. $\$ 3.00$. 


\section{CABBA GE-Second Early Varieties}

\section{Henderson's Early Summer A second}

\section{bage, which matures about ten divs after the Jersey} IV akefield. It makes a large, solid, flattish head. Pkt. 5c. and 10c., oz. 25c., 1/4 lb. 85c., 1b. $\$ 3.00$.

Succession A good second early round-headed s few days after the Early Sunmer. Pkt. 5c. and 10 c., oz. $25 \mathrm{c} ., 1 / 1$ lb. 85 c., 1b. $\$ 3.00$.

Surehead For a sure header this has proved Surehead one of the best of middle crop Cabbages. Grows very large and solid and will be found a fine sort. Pkt. 5c. and 10c., oz. $25 \mathrm{c}$., $1 / 4 \mathrm{lb}$. \$5c., lb. $\$ 3.00$. All Seasons A very popular variety as a second
early. The heads are large, solid and keep well in Winter; ready to cut as soon as Early Summer. Plkt. 5c. and 10c., oz. 25c., 1/4 lb. 85́c., lb. $\$ 3.00$.

Early Dwarf Flat Dutch One of the mos: liable of the medium early varieties. flattish-shaped, solid heads. Pkt. 5c. and 10c., oz. $25 \mathrm{c}$., $1 / 4$ lb. $85 \mathrm{c}$., lb. $\$ 3.00$.

\section{CHINESE, or CELERY CABBAGE}

Also called Pe-Tsai, and Cut Cabbage, by Chinese gardeners and is beginning to attract attention in America. It does not form a Cabbage head, but when grown to its full size resembles the Cos Lettuce and the outer leaves may be used during its growth. It is odorless while being cooked, and the flavor is delicious, being rery mild, and it is excellent for use as a salad or cooked like Asparagus. We are quite sure that it will please all who partake of it. Sow seed after July 1st, and give plenty of room to the plants, setting in rows 3 feet apart and 2 feet apart in the row. Pkt. 10c., oz. 40 c., $1 / 4$ lb. $\$ 1.25$.

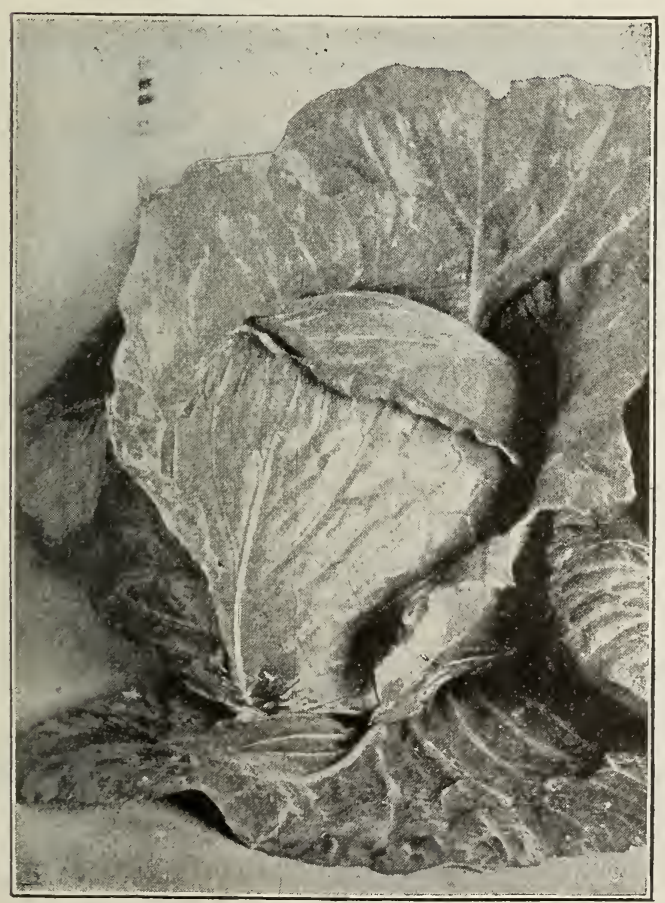

Schultz's Large Late Flat Dutch Cabbage

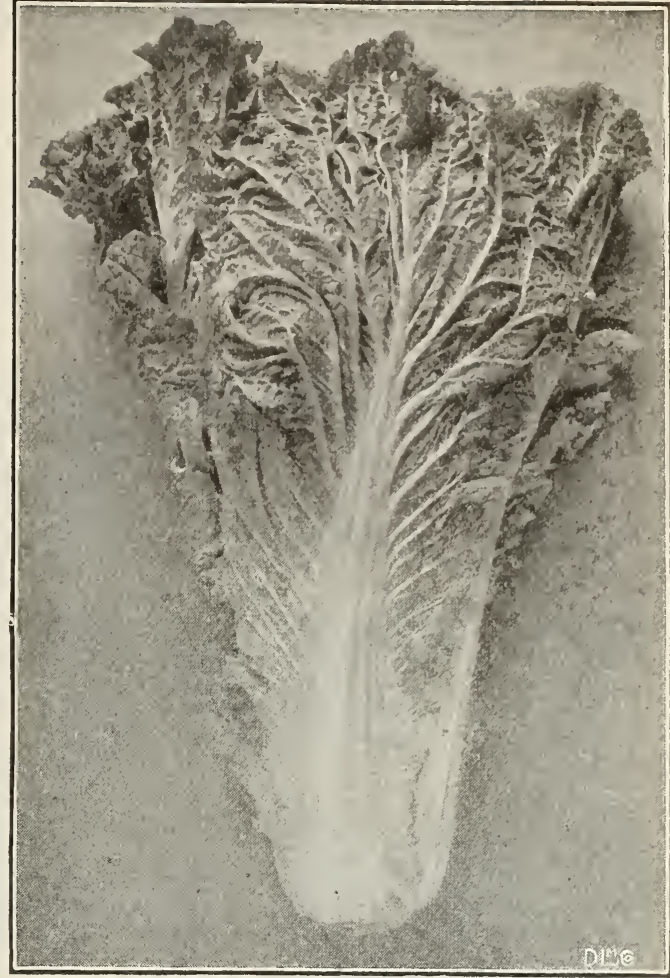

Chinese, or Celery Cabbage

Late, or Autumn Sorts Schultz's Large Late Flat Dutch

Pronounced by experienced Cabbage growers to be the finest strain of Late Flat Dutch Cabbage in the world. It grows very large, and never fails to make a perfect, solid head, is most uniform in shape and keeps well over Winter. Pkt. 5c. and 10c., oz. 25c., $1 / 4$ lb. $85 \mathrm{c}$., lb. $\$ 3.00$.

The Volga The heads are uniform and solid, each; flesh firm, sweet and tender to 15 pounds 10 c., oz. $25 \mathrm{c}$., $1 / 4$ lb. 85 c., lb. $\$ 3.00$.

Premium Flat Dutch The heads are round in shape. Excellent keeper. Pkt. 5c. and 10c., oz. $25 \mathrm{c}$., $1 / 4$ lb. $85 \mathrm{c}$., lb. $\$ 3.00$.

Holland, or Danish Ballhead

A vigorous grower, of compact growth; is extremely hardy and in quality it is one of the best, being very white, crisp and tender. Pkt. 5c. and 10c., oz. 35c., $1 / 4$ lb. $\$ 1.15$, lb. $\$ 4.00$.

Perfection Drumhead Savoy Savoy

Cabbages are very tender and of fine flavor, very. much superior in this respect to the ordinary late Fall and Winter Cabbage. Should be much more largely grown, both for home use and market. The strain of American Drumhead Savoy which we offer makes large-sized heads of most superior quality; truckers and private gardeners alike will find it an excellent variety. Pkt. 5c. and 10c., oz. 30c., 1/4 lb. $\$ 1.00, \mathrm{lb} . \$ 3.50$.

Mammoth Red Dutch By far the hest, est heading red Cabbage ever introduced. The plant is large, with numerous spreading leaves, and the head large, round, very solid, and of deep red color inside as well as outside. Pkt. 5c. and 10c., oz. 50c., 1/4 lb. $\$ 1.50$. 


Schultz's Seed Store, Washington, D.C.

\section{CARROT}

Carotte, Fr. Carota, Ital.

One unnce will sow 100 feet of drill; three to four pounds required for acre.

Culture-April is the time to sow for early use. Sow seed in drills 12 to 15 inches apart, and thin out from 3 to 4 inches in drill, covering seed about one-half inch. For general crop sow in May same distance apart as above but cover seed a little deeper as sun is stronger. Perfect specimens require a fine, pulverized, deep soil.

\section{Danvers Half-Long Improved $\begin{gathered}\text { For a } \\ \text { general }\end{gathered}$}

crop, the best, the largest vield, the most profitable for the market gardeners. Roots medium length, deep orange, tapering uniformly to a blunt point; smooth and handsome. Flesh sweet, crisp and tender. It is now grown largely everywhere on account of its great productiveness and great adaptability to all classes of soil. Pkt. 5̃c. and $10 \mathrm{c} .$, oz. $15 \mathrm{c} ., 1 / 4 \mathrm{lb} .35 \mathrm{c}$., lb. $\$ 1.00$.

Rubicon Half-Long The finest bunch Carrot in existence today.

This is an entirely new and distinct American strain. finely shaped and of beautiful deep orange color. It grows without neck, and is hollow crowned. It is excellent for growing under glass or outside at any season of the year. Pkt. כ́c. and 10c., oz. 15c., $1 / 4 \mathrm{lb}$. 35̃c., lb. $\$ 1.00$.

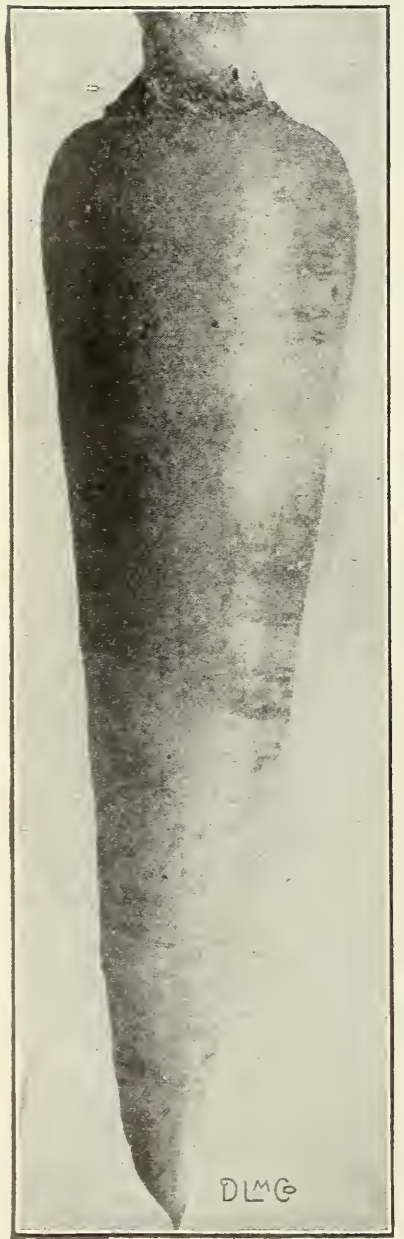

Improved Leng Orange Carrot
THIRTY (30) YEAR'S

actual experience back of Schultz's Seeds. We test all our Seeds for germination, and are sure they will grow. $35 \mathrm{c} ., \mathrm{lb} . \$ 1.00$ $1 / 4$ lb. 75 c., lb. $\$ 2.50$.

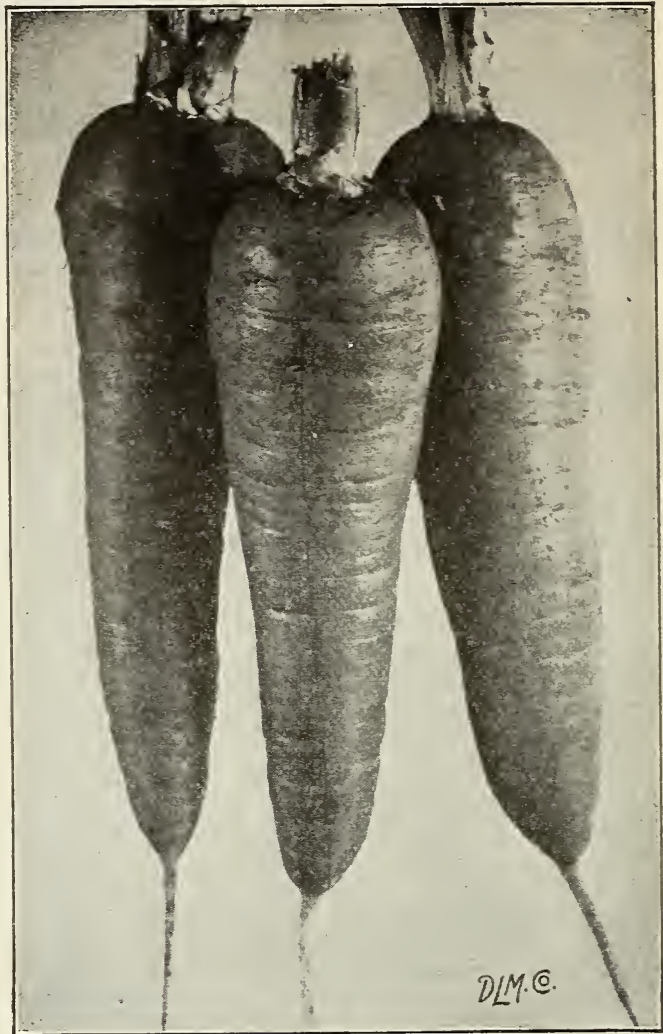

Danvers Half-Long Carrots

Improved Long Orange A well-known sort; roots long, thickest point; color deep orange. It is a good keeper and extensively grown for stock feeding. Pkt. 5́c. and 10c., oz. 15c., 1/4 lb. 35c., lb. $\$ 1.00$.

Early Chantenay. The Carrots grow about 6 inches long, are stump rooted, very smooth, deep red, fine grained, sweet and sugary. Pkt. 5c. and 10c., oz. 15c., $1 / 4$ lb. 35 c., lb. $\$ 1.00$.

Pride of the Market The highest colored and most beautiful yielder of all Carrots: smooth, straight and free from roughness; it is early, without core very tender and sweet. Pkt. 5c. and 10c., oz. $15 \mathrm{c} ., 1 / 4 \mathrm{lb}$. 35c., lb. $\$ 1.00$.

Ox-Heart, or Guerande. It is intermediate as to length between the halflong varieties (such as Danvers) and the Short Horn Carrot, but much thicker than the latter, attaining at the top from 3 to 4 inches in diameter. It is a very fine quality for the table. Pkt. $5 \mathrm{c}$. and 10c., oz. $15 \mathrm{c}$., $1 / 4 \mathrm{lb}$. 35c., lb. $\$ 1.00$.

Early Scarlet Horn. Early and popular; fine for the private and market garden. Grows about 4 inches long. Pkt. 5c. and 10c., oz. $15 \mathrm{c} ., 1 / 4 \mathrm{lb}$.

\title{
COLLARDS $\begin{gathered}\text { Chou Coba, }, F r \\ \text { Cavolo, Ital. }\end{gathered}$
}

One ounce will produce 3000 plants.

Culture.-Sow seed as for Cabbage, in June, July and August for succession. Transplant when a month old in rows a foot apart each way and hoe often.

True Georgia. Pkt. 5c., oz. 15c., $1 / 4$ lb. 35c., lb. $\$ 1.00$.

\section{CORN SALAD, or FETTICUS}

\author{
Mache, Fr. ERBa Riccia, Ital. \\ One ounce will sow 150 feet of drill.
}

Culture.-Sow during August or early in September, in drills $1 / 4$ inch deep and 6 inches apart. If the weather is dry when the seed is sown, tread it lightly to insure germination. Just before the Winter, cover thinly with straw or leaves. The seed may also be sown in the Spring.

Large-Seeded. The most popular variety grown. Pkt. $5 \mathrm{c}$. and 10c., oz. 25c. 


\section{CAULIFLOWER Croorntran,,$F_{\text {. }}$ \\ Cavolflori, Ital.}

One ounce of seed produces about 2000 plants.

Culture.-Cauliflower succeeds well in any soil where Cabbages will grow. It delights in a rich soil and abundance of water. Sow the seed in a hotbed in January or February, and when the plants are large enough, trans. plant 3 inches apart in boxes or in other hotbeds until time to plant out. If hardened off they are seldom in jured by planting out as early as the ground can be properiy prepared, in rows about $21 / 2$ feet apart, and 2 feet between the plants. The Cauliflower succeeds best when planted in frames at the close of Winter, and brought to maturity before the Summer heat sets in. Late varieties which mature in Autumn are sown and managed like Winter Cabbage.

\section{Henderson's Snowball Cauliflower}

Is beyond question the best for either early or late For family or market garden. For forcing or coldframes. It heads where others fail. Henderson's Snowball Cauliflower is superior to all others. It is the earliest of all Cauliflowers. For forcing under glass during Winter and Spring Henderson's Snowball is peculiarly adapted. We are in a position to supply the most critical market gardener with seed which can be depended upon as the very best. Pkt. $10 \mathrm{c}$. and $25 \mathrm{c}$., $1 / 2 \mathrm{oz}$. $\$ 1.25, \mathrm{oz} . \$ 2.25,1 / 4 \mathrm{lb}$. $\$ 7.25$.

\section{Dry Weather Cauliflower $\begin{gathered}\text { During } \\ \text { some sea- }\end{gathered}$} sons, after a very late Spring, hot weather comes on very quickly. In such a year this variety has proven itself of exceptional merit. Very sure heading and second early. Heads larger than Snowball, and snow white. Our seed is $\mathrm{A} 1$, and procured from the original grower in Denmark. Pkt. 10c. and 25c., $1 / 2 \mathrm{oz}$ $\$ 1.25$, oz. $\$ 2.25,14$ lb. $\$ 7.25$.

Early Favorite This is very early, exceedingperhaps the best sort for the inexperienced grower, as it will head under conditions in which many sorts would fail. Pkt. 5c., oz. $\$ 1.25,2$ oz. $\$ 2.00,1 / 4 \mathrm{lb}$. $\$ 3.50$.

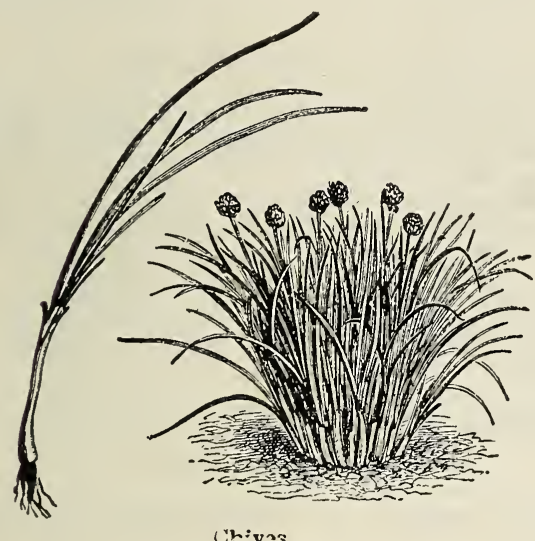

Lhivas

Chicory Chicoríe sauvage, Fr.

One ounce will sow a bed of four square yards.

Culture.-Sow in Spring, in drills one-half inch deep, in good, mellow soil.

Large-Rooted, or Coffee. Leaves blanched, are esteemed as an excellent salad. Pkt. 5c. and 10c. oz. $15 \mathrm{c} ., 1 / 4 \mathrm{lb} .40 \mathrm{c}$

\section{Whitloof, or French Endive esteemed}

plant. Spring-sown seeds produce Pars by November. Cut the leaves off $11 / 2$ inch from neck, trench $11 / 2$ inch apart, cover with soil 8 inches over crown; then place a 2 or 3 foot laver of fresh manure which induces new growth of blanched leaves folded like Cos Lettuce, which are eaten raw as salad. Pkt. $5 \mathrm{c}$. and 10c., oz. 30c., $1 / 4$ lb. $\$ 1.60$, lb. $\$ 3.50$.

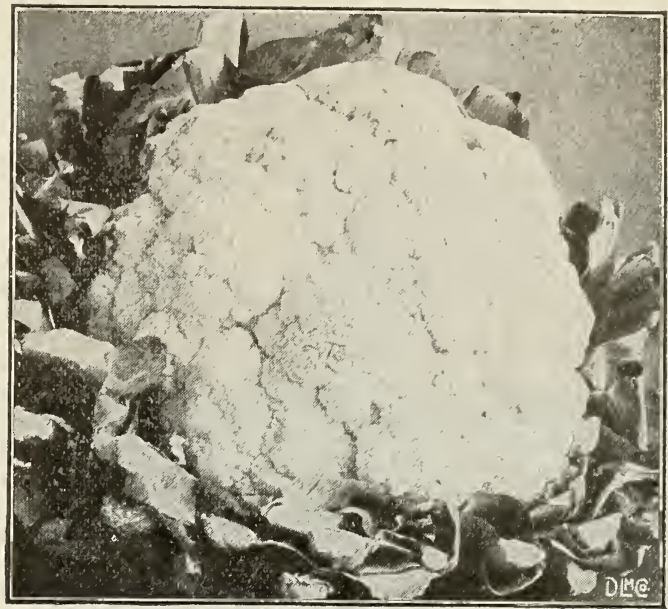

Early Favorite Cauliflower

\section{Chives}

Chives are a small, hardy perennial plant, resembling the Onion in appearance and growing in clusters. They are grown for the young leaves which are produced ireely from early in the Spring throughout the Summer. They give a mild Onion flavor to sausages, salads and various dishes. The tops appear early in the Spring and can be shorn off close to the ground as needed. Big roots, 30c. a bunch, 6 for $\$ 1.50$.

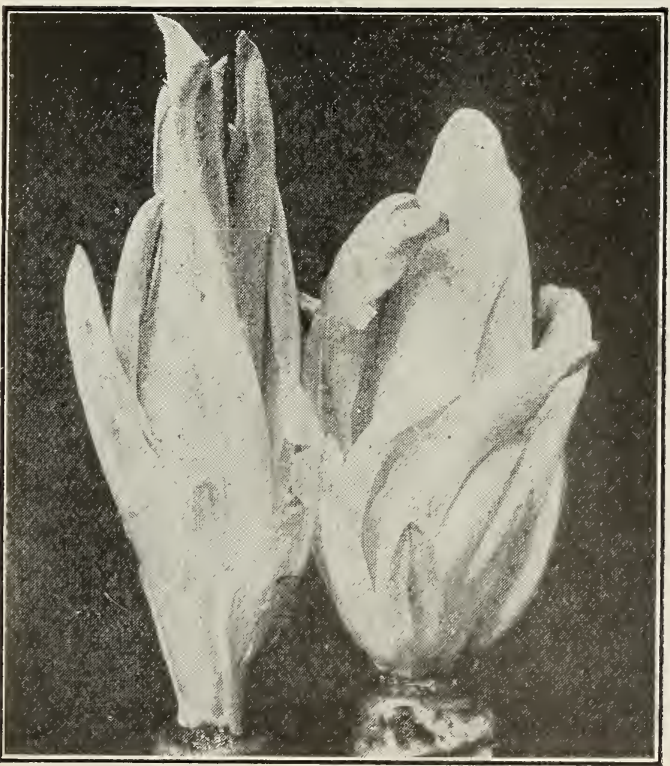

Witloof Chickory 


\section{CELERY}

One ounce will produce about 3000 plants. One-half pound of seed sufficient to sow one acre.

Culture.-Sow the last of March or early in April, in drills 8 to 10 inches apart. The seed should be covered very lightly or merely pressed into the earth. When fairly out of the seed leaf they may be transplanted to another bed, or else thinned out to 4 inches apart, and let them grow until wanted for transplanting out into the beds or trenches in July. Some gardeners trim off the tops a little, while the plants are small, to make them grow more stocky. The trenches should be shallow, and about 4 feet apart, and wide enough to hold one or two rows. These rows should be 1 foot apart and the plants set about 6 inches apart in the row. As the plants grow, they should be earthed up to blanch them, care being taken not to let the earth get into the heart of the plant. For keeping over the Winter, bank up with earth and cover over with litter to keep out the frost, placing boards on top to keep out the rain.

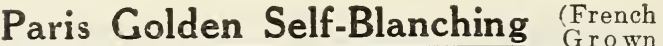

Seed). It is of compact growth, with a large, solid heart, and thick-ribbed stalks, which blanch easily. It is crisp and solid, free from stringiness, and of most deliciou; flavor. Color beautiful golden yellow, both stalks and leaves. Largely used by our Southern truckers and gardeners. Our strain of this variety is unsurpassed. Pkt. 5c. and 10c., oz. 50c., 1/4 lb. $\$ 1.75,1 \mathrm{~b} . \$ 6.50$.

\section{New York Giant Self-Blanching}

It is earlier and larger than White Plume, and fully as large as Golden Self-Blanching; very solid and of

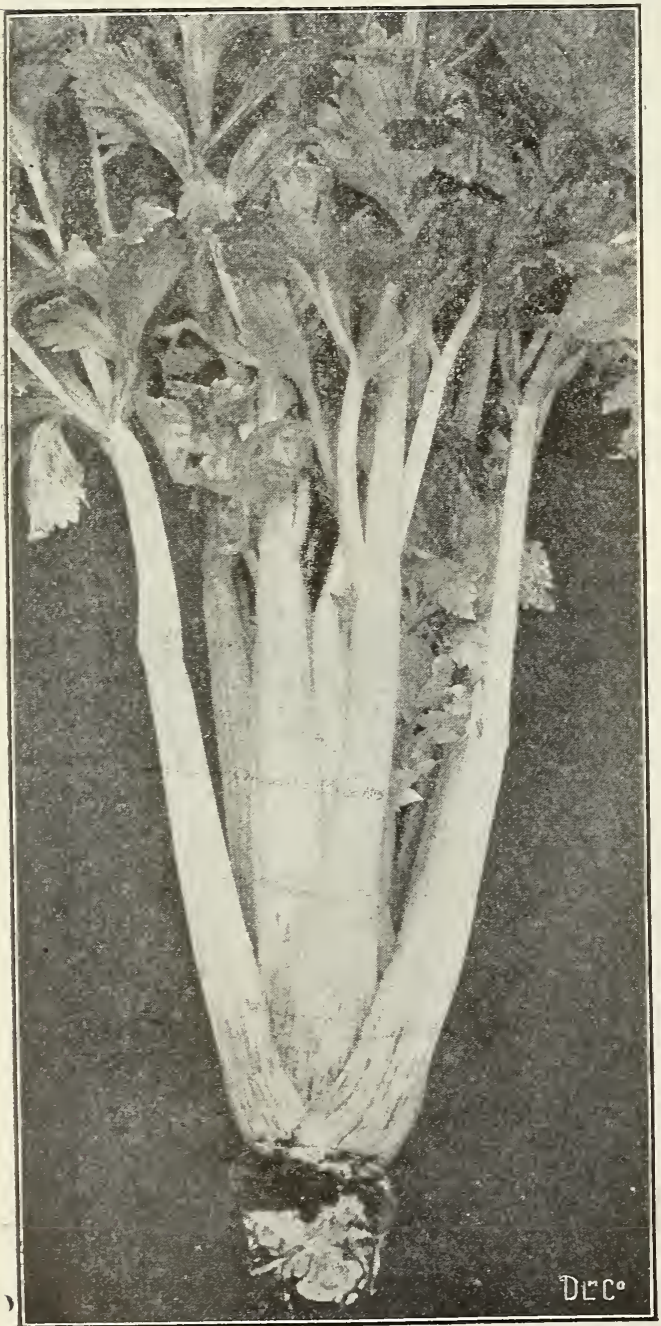

Selected Strain French-Grown Paris Golden Self-Blanching Celery excellent flavor. It is by far the best white Celery that we know of, and can be sown very early without running to seed. It originated in a block of Giant Pascal, having the size and quality of the parent, but with a distinct self-blanching habit, which runs wcnderfully true to type. As a table Celery we know of no superior. Pkt. $5 \mathrm{c}$. and $10 \mathrm{c} ., 0 z .25 \mathrm{c} .1 / 1 / 1 \mathrm{lb} .8 \tilde{\mathrm{c}}$., lb. $\$ 3.00$.

New Easy Blanching An attractive feature of this variety produces many golden hearts which are decidedly crisp, very tender and of excellent flavor. In addition to these desirable qualities, it is one of the best of the Winter-keeping Celeries, and may be allowed to remain in the trench for a long time, and will come out in first-class condition, solid and free from rot. The plants make a strong growth and are very easy to blanch which is a decided advantage to the amateur gardener, and also a valuable feature for the market grower. Pkt. 5c. and 10c., oz. 25̃c., 1/4 lb. 85̃c., lb. $\$ 3.00$.

Improved White Plume chis matures and lier than any other Celery, being entirely white or light foliage which requires little earthing up to blanch. Its special features are, handsome appearance and good quality. Pkt. $5 \mathrm{c}$., oz. 20c., 1/4 lb. 60c., lb. $\$ 2.00$.

Giant Pascal Of excellent flavor. Has large, thick, solid stalks, beautiful golden heart. and blanches quickly. Of splendid keeping qualities, and being one of the best for Winter use, is extremely popular. Pkt. 5c., oz. 20c., $1 / 4$ lb. 60c., lb. $\$ 2.00$

Golden Heart, or Golden Dwarf. A standard sort of excellent flavor. Pkt. 5c., oz. 15c., $1 / 4 \mathrm{lb}$. 50c., lb. $\$ 1.50$.

Winter Queen Grows very thick, solid, and heart. Pkt. 5c. and 10c., oz. $15 \mathrm{c} ., 1 / 4$ lb. 50c., lb. $\$ 1.50$.

Schumacher Beautiful golden heart and of fine flavor. This variety is $10 \mathrm{c}$, oz. $15 \mathrm{c}$., $1 / 4 \mathrm{lb}$ l $50 \mathrm{c}$., lb. $\$ 1.50$.

CELERY SEED. For flavoring soups. 1/4 lb. 20c., lb. $50 \mathrm{c}$.

\section{CILRIAC Céleri-rave, Fr.}

\section{or Turnip-Rooted Celery}

One ounce will sow a bed of nine square yards.

Culture.-Sow in light, rich soil early in Spring; transplant in May in beds and water freely. When plants are full grown earth up the bulbs to a height of 4 or 5 inches. In a month they will be blanched. The roots will be ready in October and are used in soups.

Large Smooth Prague of improved form Celery, producing large, smooth roots, which are almost round and of fine flavor. Pkt. 5c., oz. 20c., $1 / 4 \mathrm{lb}$. 60c., lb. $\$ 2.00$. 


\section{CORN Sweet, or Sugar \\ Mais, $F r$. Grano Turco, Ital.}

One quart will plant 200 hills. One peck sufficient for one acre in hills.

If wanted by mail, add for postage.

Culture.-Plant in hills 3 feet apart each way, dropping five or six kernels in each hill, or in rows 3 to 4 feet apart, and the plants thinned out to 8 or 9 inches in the row. From May until the middle of July a succession planting can be made every 2 or 3 weeks, and by selecting the varieties a continued supply can be had until frost kills the plants.

Schultz's Snow White Evergreen Pearly whiteness and sweeter than any Sugar Corn grown. This is without doubt the most valuable Sugar Corn introduced for many years past. It is white as chalk, very pure and clear. All the large ears are filled with very deep. thin grains of pearly whiteness, and sweeter than any Sugar Corn grown. The stalks are of strong, vigorous growth, 6 to 7 feet hivh. All the rood points of the famous Stowell's Evergreen are retained and intensified in this superb variety. Pkt. 10c., pt. 25 c., qt. 40 c., gal. $\$ 1.25$, pk. $\$ 2.00$, bus. $\$ 7.00$.

Schultz's Gold Prize A new, early or intermediate, yellow Schultz's Gold Prize grained Sweet Corn of distinctive merit The ears are nearly twice the size of Golden Bantam, usually twelve-rowed and when in condition for use are light creamy yellow in color. The grain is rery sweet and tender and is unsurpassed in quality. In season it is a few dar's later than Golden Bantam, but remains in condition much longer than that variety. An excellent sort both for home and the market garden. Pkt. 10c., pt. 30c., q t. 60c., gal. $\$ 2.00$, pk. $\$ 3.50$.

Golden Bantam A very early Sweet Corn, with golden-yellow Golden Bantam grain, very tender and of excellent quality. The ears are eight-rowed, 6 to 7 inches long and of medium size; found most suitable for the table. The flavor is exceptionally rich and delicious. Pkt. 10c., pt. 25c., qt. 40c., gal. $\$ 1.40$, pk. $\$ 2.50$.

Burpee's Howling Mob Is ready for use only three to five days both are planted at the same time, but the ears are much larger in size, while the grains are nuch whiter and sweeter. Pkt. 10c., pt. 25c., qt. 40c., $1 / 2$ pk. $\$ 1.25$, pk. $\$ 2.00$.

Country Gentleman One of the most delicious and sweetest of It all the Sweet Corns. A main crop variety. It is extremely productive. The small, irregular kernels are very deep and pure white in color. Ears average 9 inches in length. Our seed stock has been especially selected for sweetness and quality. Pkt. 10c., pt. 25c., qt. 40 c., gal. $\$ 1.25$, pk. $\$ 2.25$, bus. $\$ 8.00$.

Stowell's Evergreen I.arge, fine flavored; ears borne in abunStowell's Evergreen dance, with deep kernels. Main crop sort. To supply the right seed of this favorite has been our careful effort. Seed sown near the Eastern Atlantic Coast has alwavs shown by its flavor and shriveled, ripened kernels, the highest percentage of sugar known. Long and deep kernels are also a characteristic of selected seed of Stowell's. We invite comparison of the stock we offer with that offered by lower priced houses. Pkt. 10c., pt. 25c., qt. 40c., gal. $\$ 1.25$, pk. $\$ 2.00$ bus. $\$ 6.00$.

Kendel's Early Giant Remarkably large in ear for a second early Kendel's Early Giant sort and extensively grown in some localities for the market. The stalks are about five and one-half feet high. The ears are about 8 to 9 inches long, twelve-rowed. The grain is white, rather broad and shallow, and the quality very good. Pkt. 10c., pt. $25 \mathrm{c}$., qt. 40 c., gal. $\$ 1.25$, pk. $\$ 2.00$.

Ideal Extra Early While not a Sugar Corn the ears are large che ears average 8 to 10 inches in length, and present an attractive appearance. For earliness the Ideal Extra Early is hard to beat. It can generally be depended on to come to maturity inside of 70 days. It can be planted fully as early as the Adams, for the plants are hardy and will stand slight frosts. We recommend Ideal Corn to all market gardeners as a money maker. Pkt. 10c., pt. 20c., qt. 35c., gal. $\$ 1.00$, pk. $\$ 1.75$, bus. $\$ 6.00$.

Black Mexican A black grained variety, sweet and tender. Pk. 10c., pt. 25c., qt. 40c., $1 / 2$ pk. $\$ 1.25$, pk. $\$ 2.25$.

Adams' Extra Early It can be planted earlier than any other, Pt. 20c., qt. 30c., gal. 85 c., pk. $\$ 1.50$, bus. $\$ 5.00$.

Early Adams An excellent early variety and often used for table. pk. \$1.50, bus. $\$ 5.00$.

Rice Pop Corn A very handsome and prolific variety. Ears short, white. Lb. 20c.
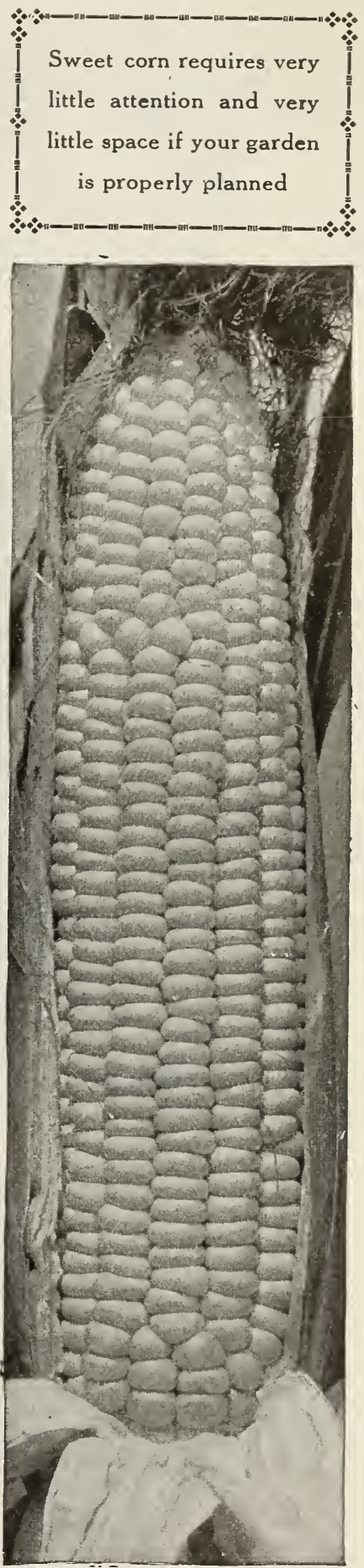

Schultz's Snow White Evergreen Sugar Corn 


\section{SCHULTZ'S TESTED FIELD CORN}

Six quarts will plant one acre in hills.

\section{Selected Hand-Picked Quality. FOR FODDER AND ENSILAGE}

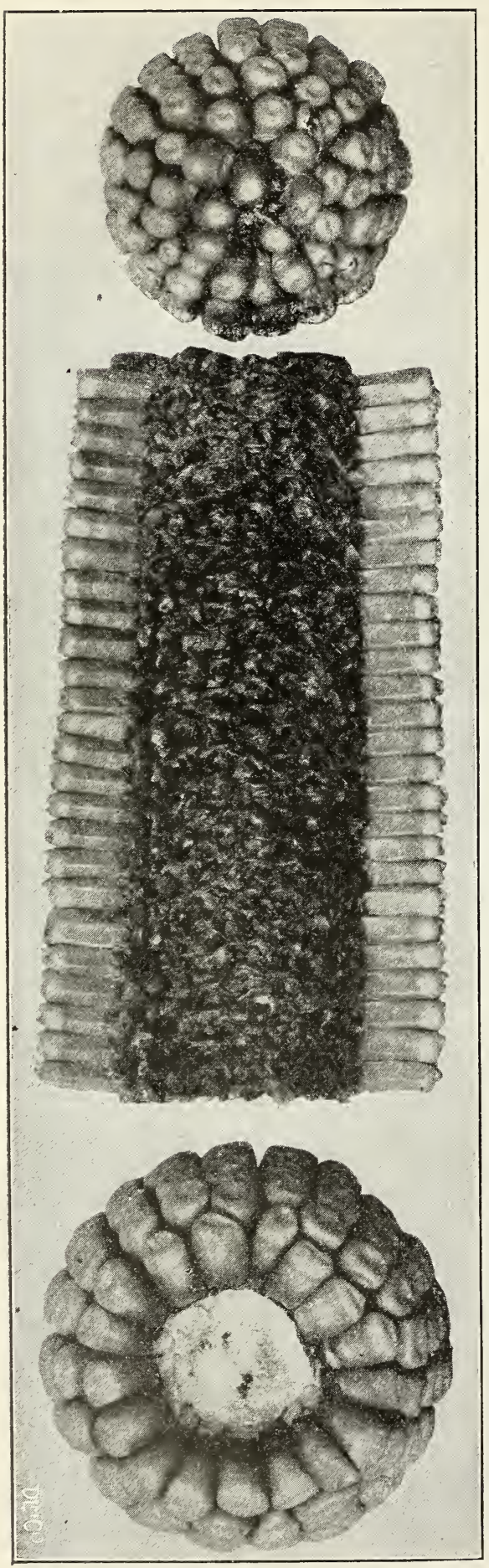

Thoroughbred Yellow Dent
All our Field Corn is "Tipped" and "Butted" and selected on the ear before being shelled and tested for germination.

Attention is more and more being given to the careful selection of Seed Corn, and the very much larger yields that can be obtained by care and selection of the seed and in proper culture and tillage greatly increased results can be obtained. The interest in improved Seed Corn is attested ky the various prize Corn Contests over the country, and these should be encouraged in every way. The varieties listed here are carefully grown for seed and will be found first-class in every respect; all carefully tested for germination before sending out.

Boone County White Highly bred White Corn, fodder growth. Is a highly bred White Corn, extra large ear, contains a high percentage of protein, maturing about medium. The ears range from 8 to 12 inches long, $71 / 2$ to 8 inches in circumference, with 18 to 24 rows of Corn, with from 1000 to 1200 grains to the ear, and averaging in weight from 12 to 18 ounces. The cob is medium to large, pure white, both butts and tips are remarkably well filled, grains are very deep, fine, large germ and the greatest yielding Corn in existence. $\mathrm{Pk}$. $\$ 1.00$, bus. $\$ 3.50$.

Hickory King. Small cob, broad grain, eight-rowed, true stock. Smallest cob and the largest grained White Corn in cultivation. Ripens in 100 to 120 days. It husks and shells easily and produces much fodder. $\mathrm{Pk} . \$ 1.00$, bus. $\$ 3.50$.

Thoroughbred Yellow Dent Deep grained, very heavy cropper. If any seed grain can truly be called pedigreed, the Thoroughbred Yellow Dent Field Corn is certainly entitled to be known as such, as its history dates many years back. It has been bred up and selected with painstaking care to what is at the present time one of the best varieties of yellow Corn grown. Ear medium in size, remarkabiy uniform, and of a bright yellow color, with solid, deep grain and small, red cob. Has from 18 to 24 rows of kernels on the cob, 50 to 60 grains in the row, and is well filled over the ends, and especially the butt, leaving a small shank, which makes it a great favorite with huskers. Best shredding sort, as it shatters the least of any by actual test. Pk. $\$ 1.00$, bus. $\$ 3.50$.

Eureka Ensilage Corn A very large-growing, of the best silo Corns. White grain, grows 12 to 15 feet in height, makes an enormous lot of fodder and bears from three to five ears to the stalk. 150 bushels of shelled corn per acre is not unusual. Especially recommended to dairvmen as it is strictly a fine Corn for the silo. $\mathrm{Pk} . \$ 1.00$, bus. $\$ 3.25$.

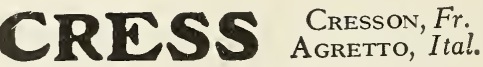

One ounce will sow 15 square feet.

Culture.-Easily grown during Winter on the greenhouse bench, in frames, or boxes, and splendid for salad, garnishing, or as an addition to Winter Lettuce. Sow seed very thickly in rows 3 to 6 inches apart under glass, or for Summer 1 foot apart in open ground. Sow ofter for succession, as it soon runs to seed. Water Cress requires a stream of running water, ditch or pond, in which it will grow without care, except at first keeping weeds from interfering with it.

Extra Curled, or Pepper Grass. Pkt. 5c., oz. 15c., 1/4 lb. $25 \mathrm{c}$, lb. $75 \mathrm{c}$.

Water Cress. Pkt. 5c. and 10c., oz. 35c., $1 / 4 \mathrm{lb}$. $\$ 1.00, \mathrm{lb}$. $\$ 3.50$. 


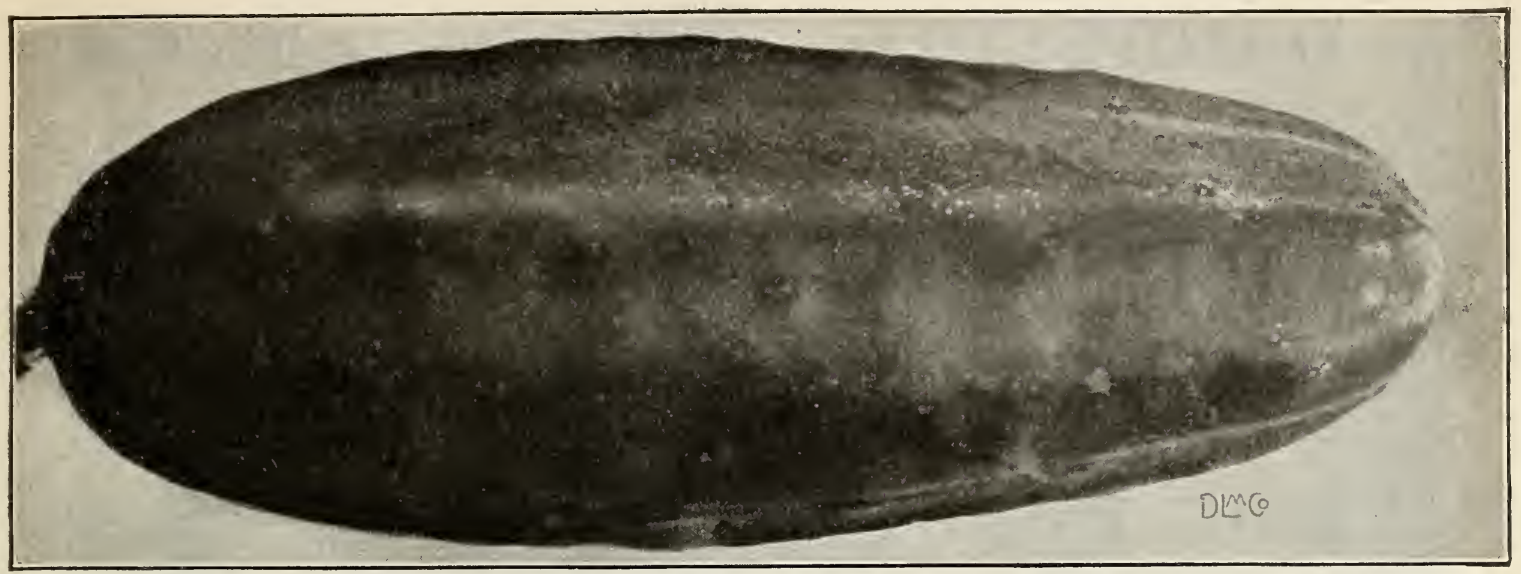

Klondike Cucumber

\section{CUCUMBERS}

One ounce will plant about 50 hills; two pounds to the acre.

Culture.- - Sow the seeds early in the season in a hotbed, using small sods (grass side down) or flower pots, placing a few seeds in each. When all danger of frost is past, transplant into hills, which should be 4 feet apart each way. For general crop, a sowing may be made in the open ground in May, in rich, mellow soil, well manured, using eight or ten seeds to each hill, and when danger of insects is past, thin out to four plants to each hill. For pickles, sow from the middle of June to first week in July. Pick all fruit when of proper size.

Schultz's Evergreen This variety as it beis driving other sorts out of the market. We predict a great future for this sort. Earlier than the Improved Arlington White Spine and a heavier cropper. Truckers who desire an early Cucumber will find in this new variety a money maker. It is one of the most vigorous, strong and robust growers. Fruits are even size, very handsome shape, measuring about 8 to 9 inches in length; excellent for slicing. Fine for forcing or outdoors. Pkt. 5c. to 10c., oz. 15c., $1 / 4$ lb. 35c., lb. $\$ 1.00$.

Burpee's Fordhook Famous The largest, some garden cucumber-the most fleshy and finest in flavor of the White Spine Type. The vines are of strong, vigorous growth, with healthy foliage and set the extra-long fruits freely throughout the season. The cucumbers are uniformly smooth and regular in form, averaging twelve to fourteen inches in length; the skin is thin and tender, bright green in color, and never turns yellow, even in fully matured fruits. The flesh is very thick (the fruits being from two to three inches in diameter, with very few seeds), crisp, and exceptionally mild in flavor. Pkt. 5c. and 10 c., oz. 15 c., $1 / 4$ lb. 40 c., lb. $\$ 1.25$.

Improved Long Green of the best for slicing and pickles. A selection from the Long Green. The vines are very vigorous and productive. The fruit, which is about 12 inches long, is formed almost as early as the short sorts. They are firm, crisp, and of fine flavor. Those desiring a long, dark green Cucumber will find this strain unsurpassed. Pkt. 5c. and 10c., oz. 15c., 1/4 lb. 40c., lb. \$1.25.

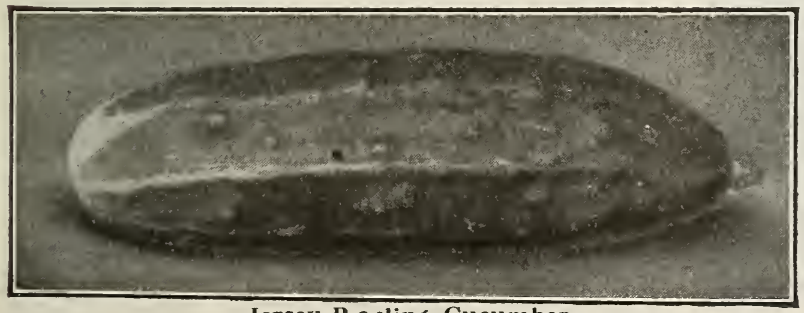

Jersey P.ckling Cucumber
Davis Perfect An excellent Cucumber for both carefully selected outdoor use and forcing. It is a Spine type, made by a veteran outdoor and greenhouse grower of Cucumbers. Its valuable points are length, slimness and its dark green color. It is a very vigorous sort, and resists blight longer than most long sorts. Pkt. 5c. and 10c., oz. 15c., $1 / 4 \mathrm{lb} .40 \mathrm{c}$., lb. $\$ 1.25$.

Klondike A medium early, white spined Cucumber of handsome, very dark green color and of excellent quality for slicing. The vines are very hardy and productive. The fruits when mature are about 8 inches long, and are uniform in size and shape. Color dark green, slightly striped at the ends. The dark green color is retained much longer and is affected less by the hot sun than any other sort with which we are familiar. Its uniform size and shape and splendid color are making this variety very popular as a shipping sort. Pkt. 5c. and 10c., oz. $15 \mathrm{c} ., 1 / 4 \mathrm{lb}$. $35 \mathrm{c}$., lb. $\$ 1.00$.

Arlington White Spine This is, without most profitable Cucumber for truckers, and is unsurpassed for the amateur. It is beyond question the earliest, most shapely and productive variety of this type; of a green color throughout its entire length, very straight and symmetrical. The quality is fine. Another strong point of merit is its shipping qualities; it seems to hold its color and brittleness long after being cut. Pkt. $5 \mathrm{c}$. and $10 \mathrm{c} ., \mathrm{oz} .15 \mathrm{c} ., 1 / 4 \mathrm{lb} .35 \mathrm{c}$., $1 \mathrm{~b} . \$ 1.00$.

Jersey Pickling This famous sort makes account of its color, makingiwhat pickle men call "light" pickle. It is more prolific than White Spine. New land turned-over pasture, makes the nicest pickle. Pkt. 5c., and $10 \mathrm{c}$, oz. 15c., $1 / 4$ lb. $35 \mathrm{~s}$, lb. $\$ 1.00$.

Small Gherkin. A very small, oval, prickly variety, quite distinct from all others and grown exclusively for pickles. The seed is slow to germinate, requiring usually from two to three weeks. Pkt. 5c. and 10c., oz. $15 \mathrm{c} ., 1 / 4 \mathrm{lb}, 45 \mathrm{c}$., lb. $\$ 1.50$.

Japanese Climbing. This is a strong and vigorous grower. Vines throw out strong tendrils, which enable it to climb a trellis or any suitable support. Fine for pickling. Pkt. 5c., oz. 15c., $1 / 4$ lb. 35c., lb. $\$ 1.25$. 


Schultz's Seed Store, Washington, D. C.

\section{DANDELION}

Pissenlit, Fr.

DENTE DI LEONE, Ital.

One ounce will sow 100 feet of drill.

Blanched leaves of this plant make a most delicate flavored and wholesome salad. The quality is improved very much by blanching, which can be easily done by covering over the plants with boards.

French (Common). Pkt. 5c., oz. 20c., 1/4 lb. 50c., lb. $\$ 1.50$.

Improved Large Thick-leaved. A thick-leaved variety of great productiveness and fine flavor. Pkt. 10c., $1 / 2$ oz. 25c., oz. 40c., $1 / 1$ lb. $\$ 1.25$.

\section{EGG PLANT}

Aubergine, $F r$.

Petronciano, Ital.

One ounce will produce about 1000 plants.

Culture.-The Egg Plant will thrive well in any good garden soil, but will repay good treatment. The seed should be sown in hotbeds the first week in March, care being taken to protect the young plants from cold at night. Plant out about June 1st, about 2 feet apart in row and 3 feet between rows. Egg Plants are very tender and will not stand frost. Sufficient plants may be raised for a small garden by sowing a few seeds in flower pots or boxes in the house.

Florida High Bush A valuable variety, bush and holds its fruit well off the ground. It resists drought and wet weather to a wonderful degree; very vigorous and productive, bearing very profusely its large purple fruits of fine shape and quality. An excellent shipper. Pkt. 5c. and 10c., oz. 50c., 1/4 lb. $\$ 1.75,1 \mathrm{~b} . \$ 6.25$. Black Beauty $\begin{aligned} & \text { From ten to twelve days earlier } \\ & \text { than New York Improved Pur- }\end{aligned}$ ple. The fruits are broad and thick, of most attractive form, and of the finest flavor. The skin is rich, lustrous, purplish black. The intensely brilliant coloring is uniform over the whole fruit and does not fade or change to a lighter color at the blossom end. The calyx is entirely free from thorns. The fruits set most freely and are ready to market early, so that the entire crop can be gathered before there is any danger of frost. Pkt. 5c. and 10c., $1 / 2 \mathrm{oz} .25 \mathrm{c}$., oz. 50c., $1 / 4$ lb. $\$ 1.75,1 \mathrm{~b} . \$ 6.50$.

New York Improved Purple. Plants of vigorous growth and very productive. Fruits of large size, with smooth, glossy, deep purple skin. Pkt. 5c. and 10c., oz. 50c., 1/4 lb. $\$ 1.75$, lb. $\$ 6.00$.

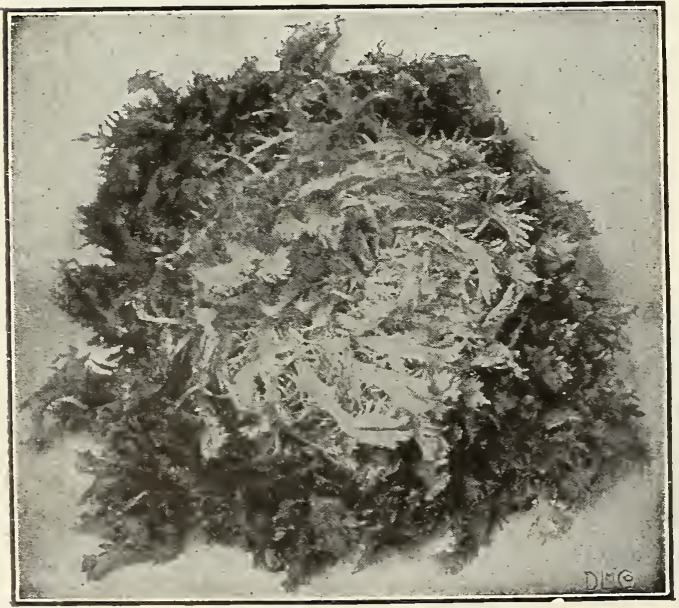

Green Curled Endive

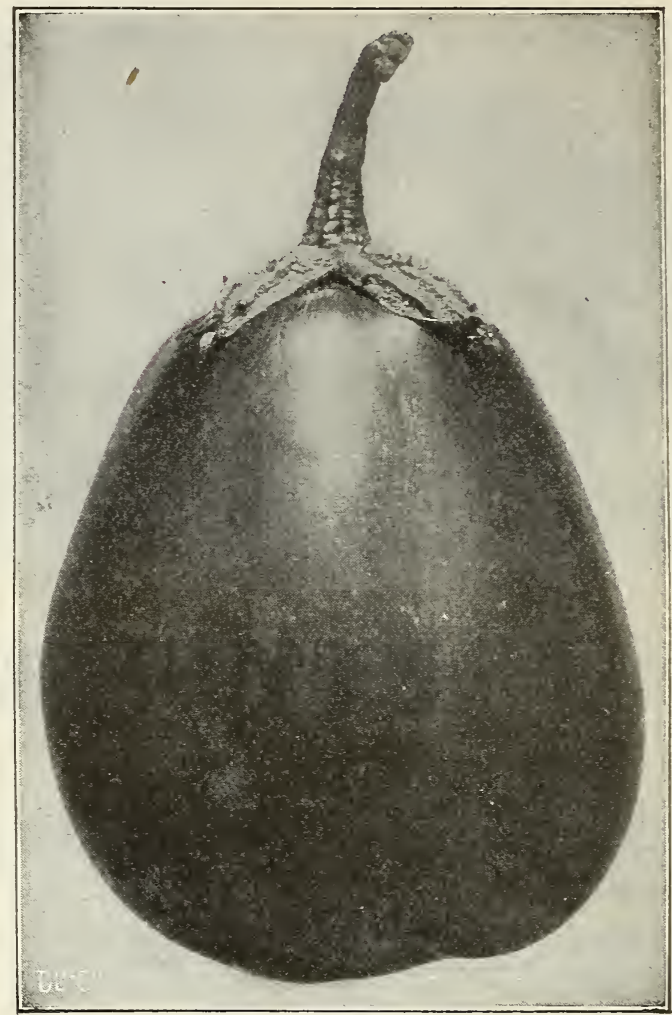

Black Beauty Egg Plant

\section{ENDIVE}

One ounce will sow 150 feet of drill.

Culture.-Endive is one of the best and most wholesome salads for Fall and Winter use. Sow in shallow drills in April for early use, or for late use in June or July. When the plants are 2 or 3 inches high, thin them out or transplant into moderately rich and rather light soil, 1 foot apart. When nearly full grown, and before they are fit for the table, they must be blanched by tying the leaves loosely together, which must be done when quite dry, or by covering with boards or flower pots.

Broad-leaved Batavian (Escarolle). Used in soups and stews; require to be tied up for blanching. Pkt. 5̃c. and 10c., oz. 15c., $1 / 4$ lb. 50c., lb. \$1.50.

Green Curled. The hardiest variety grown; beautifully curled. Pkt. 5c., oz. 15 c., $1 / 4$ lb. 50c., lb. $\$ 1.50$.

Vegetable Plants
We carry throughout the sea-
son strong, sturdy Vegetable
Plants as follows: Ca b b a ge,
Cauliflower, Celery, Chives, Egg
Plants, Horse Radish, Lettuce,
Pepper, Rhubarb, Sweet Potato
and Tomato.
For varieties and prices,
see page 34.




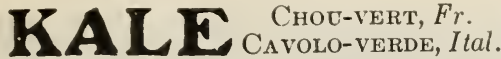

One ounce will sow 200 feet of drill; 2 pounds to the acre.

Culture.-Kales are very hardy and make excellent greens for Spring, Fall and Winter. The quality is improved rather than injured by frost if not too heavy. It is better not to cut or handle the plants while frozen, but if this is unavoidable, thaw them out in cold water. For Spring use, sow in March, or early in April; for Fall and Winter use, sow in June, July and August.

Dwarf Curled Scotch $\begin{gathered}\text { Extra } \\ \text { fin }\end{gathered}$ curled, bright green leares, tender and fine flavor. Is hardy and rarely exceeds 18 inches in height. This sort is sometimes called Norfolk and is grown extensively in the South. Pkt. 5c. and 10c., oz. 20c., 1, lb. 50c., 1b. $\$ 1.50$.

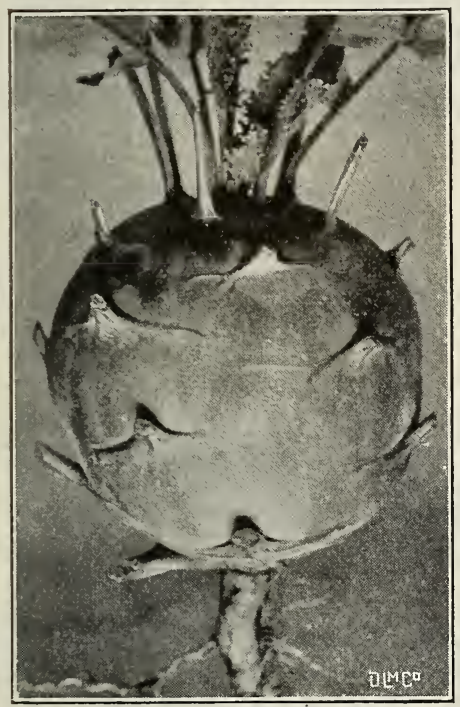

Kohi-Rabi, White Vienna

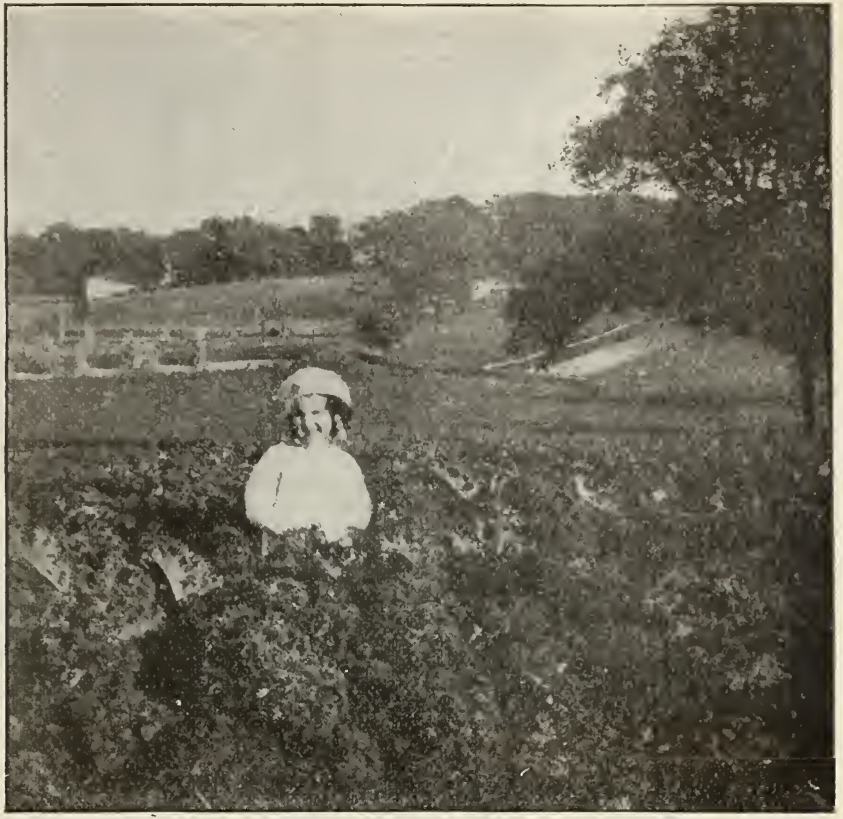

Schultz's Improved Imperial Curled Kale

Schultz Improved Imperial Curled A beautifully crumpled sort, of strong vigorous habit. The leaves are a beautiful dark green color, and delicate in flavor. A striking feature in this Kale is that it will stand longer before going to seed than any other. In the latitude of Washington it will stand throughout the Winter without protection. Pkt. 5c. and 10c., oz. 15c., 1/4 lb. 35c., lb. $\$ 1.00$.

Curled Long Standing. A very hardy, quick-growing, coarse-leaf variety. Will bolt to seed three weeks earlier than our Imperial and is not nearly as curled or crumpled. Pkt. 5c. and 10c., oz. 15c., 1/4 lb. 25c., lb. $75 \mathrm{c}$.

Siberian Curled. Of strong, vigorous habit, perfectly hardy; dark green color, and very attractive appearance. I $\mathrm{kt}$. 5c., and 10c., oz. 15c., $1 / 4$ lb. 35c., lb. $\$ 1.00$.

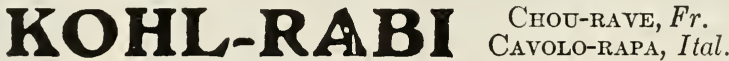
One ounce will sow a drill 200 feet long. Culture.-For early use, sow in March or April in hotbed or in open ground in Mav. Cover seed one-quarter inch deep; trazss into rows 2 feet apart and plants from 10 to 12 inches apart in rows.

Early White Vienna Extremely early, with distinctly white, handsome and of best quality. Pkt. 5c. and 10c., oz. $25 \mathrm{c}$. $1 / 4$ lb. $85 \mathrm{c}$., lb. $\$ 3.00$.

\section{LEEK PORRAT $F$ P:}

One ounce will sow 100 feet of drill.

Culture-Sow early in April in drills 1 foot apart and 1 inch deep. When the plants are 6 to 8 inches high, transplant in a deep, rich soil, in rows 12 inches apart and 6 inches in the row; as deep as possible, so that the neck may be covered and blanched; draw the earth to them as they grow. The seeds may als be sown in August or September; plants transplanted in the Spring. Giant Carentan Produces a large, thick, pure white stem and of mild, agreeable flavor.

Pkt. 5c. and 10c., oz. 25c., $1 / 4$ lb. 75c., lb. $\$ 2.75$.

\section{MUSTARD}

Sow one ounce to 80 feet of drill.

Fordhook Fancy. Dark-green leaves, making most attractive green. Pkt. 5c., oz. 10c., $1 / 4$ lb. 25c., lb. 75 c.

Giant Southern Curled. Large variety, forming a great mass of beautiful leaves. Pkt. 5c., oz. 10c., $1 / 4$ lb. 25c., lb. 75c.

Chinese. Giant leaves. Pkt. 5c., oz. 10c., 1/4 1b. 25c., lb. 75 c.

White London. Color dark green. Pkt. 5c., oz. 10c., 1/4 lb. 25 c., lb. $75 \mathrm{c}$.

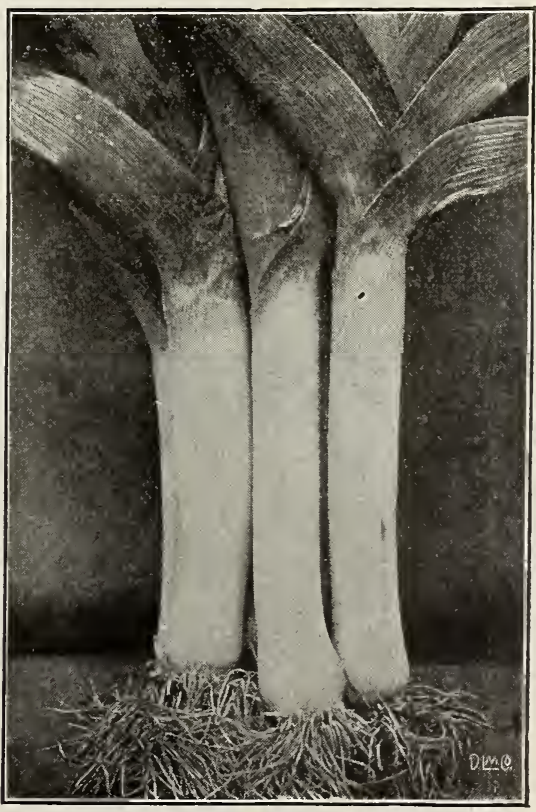

Giant Carentan Leek 


\section{Schultz's Seed Store, Washington, D. C.}

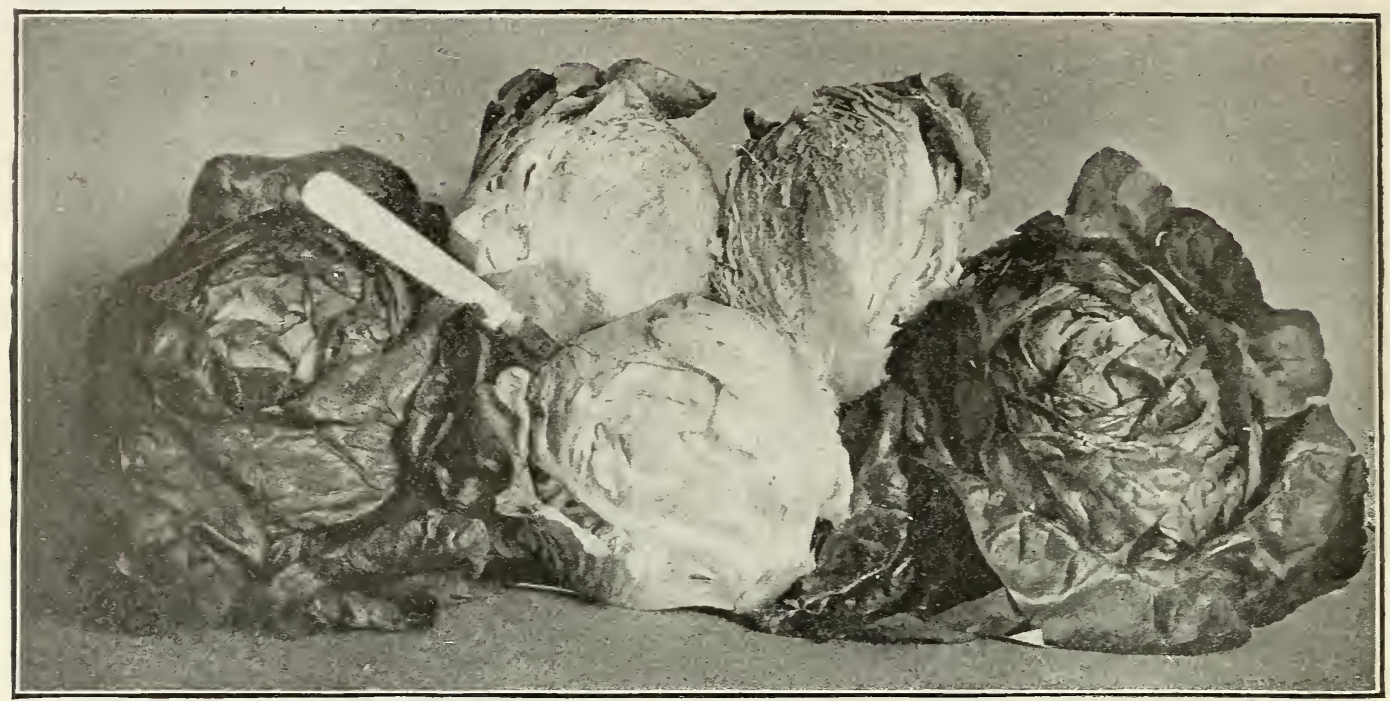

Schultz's Selected Big Boston Lettuce

\section{LETTUCE, Larres Frit}

One ounce will produce about 3000 plants; one ounce will sou 200 feet of drill.

Culture.-Seed for the first outdoor crop is usually sown in hot beds in February or March, and the seedlings transplanted to the garden in April, 8 to 12 inches apart, in rows 18 inches apart. For a succession until frost, sow in drills in the open ground at intervals of every 2 or 3 weeks, and thin the plants to stand 8 inches apart. For plants to force in hotbeds from November until Spring, sow seed in hotbeds in the Fall.

Earliest "Wayahead" Shows a remarkof earliness, firm heading character, handsome appearance and fine quality. Both in coldframes early in the Spring and in the open ground-in Spring, Summer and early Fall months-it has proved to be not only the very earliest and surest heading of all early Lettuces we have ever grown, but also of the very finest quality at all seasons. The outer leaves are a light green, while all the inner leaves of the head are nicely blanched to a rich butter-yellow tint. Earliest "Wayahead" stands a longer time before running to seed than any other early head variety. Pkt. 10c., oz. 20c., $1 / 4$ lb. 60c., lb.s2.00.

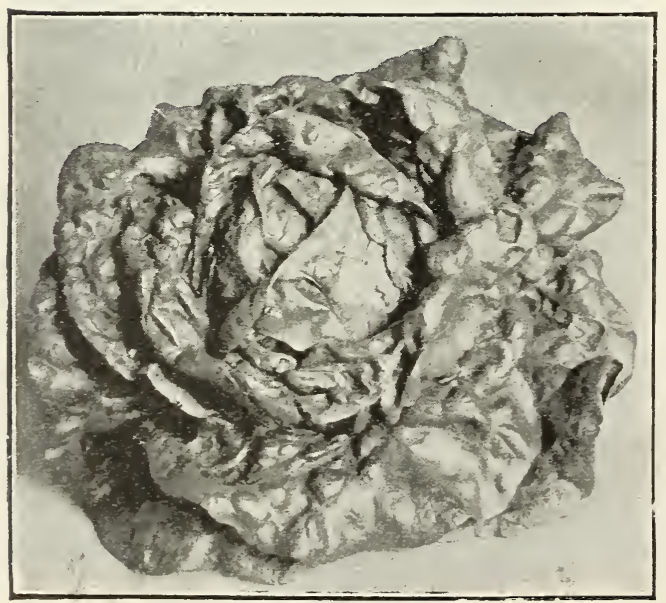

Black-Seeded Summer Lettuce
Schultz's New "Butter Ball" A grand tuce for the first time oftered An $A 11$ setof superior merit which is suited to the private gardener as well as to the Trucker. At the suggestion of a Lettuce Grower we named it "BLTTER BAI.L" in keeping with its SIIEET AND BLTTERY FLATOR. Pkt. $5 \mathrm{c}$. and 10c., oz. 25c., $1 \frac{1}{4} \mathrm{lb} .75 \mathrm{c}$., lb. $\$ 2.50$.

Schultz's "All Heart" A very superior Lettuce, appropriately named on account of the beautiful, hard head it makes. It is adapted to both Spring and Fall use. Forms large heads, leaves closely set, with extremely solid heart, even before it is half grown. The color is a beautiful light green and the flavor is excellent, being rich and buttery. Pkt. 5c. and 10c., oz. 20c., $1 / 1 / \mathrm{lb}$. 50 c., lb. $\$ 1.50$.

Schultz's Selected Big Boston $\begin{gathered}\text { The } \\ \text { most }\end{gathered}$ popular variety for every purpose on the market. Gives equally good results under glass or in the open. Of the head types it is easily the leader. Leaves are light green and very tender. Our strain of this variety is unsurpassed. Pkt. 5c., oz. 15c., $1 / 4$ lb. 50c., lb. $\$ 1.25$.

Black Seed Summer A very superior heading Lettuce. It is adapted to both Spring and Summer use, as it withstands intense heat without going to seed. It forms a large, deep, bright green, solid head; its leaves are very tender and slightly crumpled. The flavor is excellent, being rich and buttery. Pkt. 5c. and 10c., oz. $15 \mathrm{c} ., 1 / 4 \mathrm{lb} .45 \mathrm{c} ., \mathrm{lb}$. $\$ 1.50$. 


\section{LETTUCE-Continued}

May King A recent varicty of great extreme earliness, large sizc and tenderness. Will head with heat as well as out of doors, though it attains a better size with open air culture. Has a globular-shaped head of enormous size, hard and well closed. A decided acquisition. Pkt. 5c., oz. 15c., $1 / 4$ lb. $45 \mathrm{c}$., 1b. $\$ 1.50$.

Salamander For a Summer variety good-sized heads, and stands drought and heat with little injury. Pkt. 5c., oz. $15 c ., 1 / 4$ lb. 40c., lb. $\$ 1.25$

Golden Queen. Golden yellow, solid heads, fine for forcing. Of medium size. Plkt. 5c., oz. 15c., $1 / 4$ lib. $45 \mathrm{c}$., lb. $\$ 1.5 \mathrm{c}$.

Grand Rapids Forcing There is ter forcing variety among the curled-leaved sorts than the Grand Rapids, and it is quite as good for outdoor culture as other sorts. Large, beautiful leaves, very crisp and tender. Pkt. 5c. and 10c., oz. 15c. $1 / 4$ lb. 40 c., lb: $\$ 1.25$.

New York, or Los Angeles

Wonderful It has become a popular variety, where it withstands extreme heat and forms perfect head, of enormous size, which resenble cabbage in their solidity, measuring from 12 to 15 inches across and frequently weighing 2 to 3 pounds each. The quality is superb, being crisp, rich and tender, and it can be depended upon for all seasons. Pkt. 10c., oz. 25c., $1 / 4$ lb. 65c., lb. $\$ 2.00$.

Schultz's Large White Loaf A large Lettuce, with a light green color; crisp and tender: unsurpassed for outdoor planting in the Fall to stand over Winter, and equally good for coldframe culture. We do not recommend it for early Spring sowing, as it has a tendency to shoot to seed when the weather becomes warm. Pkt. 5c. and 10c., oz. 15 c., $1 / 4$ lb. 40 c., lb. $\$ 1.25$.

Tennis Ball or White Forcing A decidedvariety, strictly Cabbage heading; small, very early. The head is globular, very firm, with leaves closely overlapping one another. Color medium green, never spotted or brownish in any part. Fine quality, sweet and buttery. A most valuable sort for the market gardener for growing in hotbeds or greenhouses. Pkt. 5c. and 10c., oz. 20c.. $1 / 4 \mathrm{lb}$. 50c., lb. $\$ 1.50$.

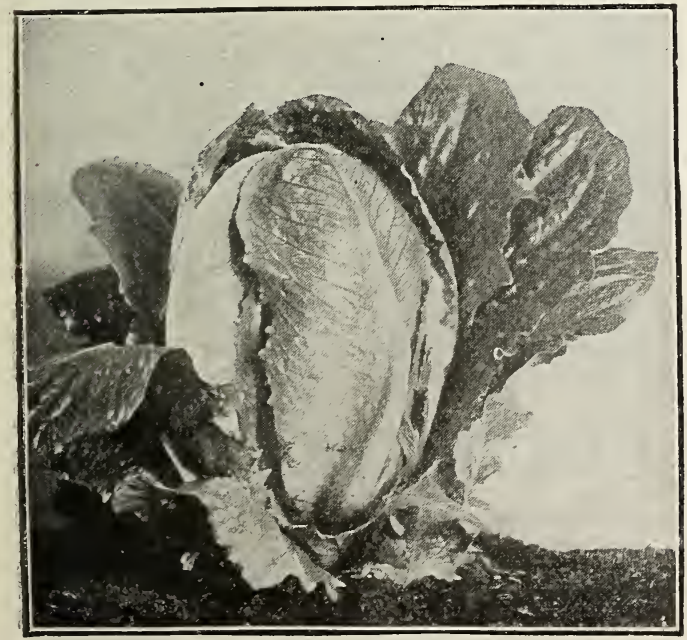

Trianon Cos, or Romaine Lettuce
Simpson's Early Curled A very extensloose leaved, or clustering variety. The leaves are light green in color, slightly frilled and much blistered, crisp, sweet and tender. The sort is especially adapted for sowing thickly and cutting when the plants are young. Pkt. 5c. and 10c., oz. $15 \mathrm{c}$., $1 / 4 \mathrm{lb}$., $40 \mathrm{c}$., lb. $\$ 1.25$.

Unrivalled A sterling new variety of the Big Boston type, without the brownsimilar in shape, appearance and orowth to the Big Boston, but with the added attractiveness of being a most decided improvement. Pkt. 5c. and 10c., oz. $15 \mathrm{c} ., 1 / 4$ lb. 40 c., lb. $\$ 1.25$.

Silesian, or Cut and Come Again

This variety should be cut instead of pulled, as it makes new growth from the same root. A light green color and when given plenty of room will form a large loose head. Pkt. 5c. and 10c., oz. 15c., $1 / 4$ lb. $40 \mathrm{c} ., \mathrm{lb} . \$ 1.25$.

California Cream Butter. This variety forms very solid heads which are tender, crisp and have a rich, buttery favor. Pkt. 5c. and 10c., oz. 15c., 1/4 lb. $35 \mathrm{c} ., \mathrm{lb} . \$ 1.25$.

Baltimore Oak Leaf This Iettuce will summer and stand longer before running to seed than any variety we have ever known. It makes a large head and is very popular. Pkt. 5c. and 10 c., oz. $15 \mathrm{c} ., 1 / 4$ lb. 40 c., lb. $\$ 1.25$.

Market Gardener's Private Stock. Largely grown for a Midsummer crop. It possesses the merit of being slow to seed. Pkt. 5c. and 10c., oz. 15c., $1 / 4$ lb. $45 \mathrm{c}$., lb. $\$ 1.50$

Black Seeded Simpson One of the best curled sorts for sowing lo os e-le a ved through the season. Very tender and remains in condition for use for a long tine. Pkt. 5c., oz. 15c., $1 / 4$ lb. 40 c., lb. $\$ 1.25$.

Improved Hanson. This is a well-tried and populat sort. Firm heads; sweet, crisp and tender. Pkt. 5c., oz. 15 c., $1 / 4$ lb. 35 c., lb. $\$ 1.25$.

Hubbard Market. A popular variety for outdoor growing. Makes large, solid heads. Stands cold weather. Pkt. 5c. and 10c., oz. 15c., $1 / 4$ lb. $40 \mathrm{c}$., lb. $\$ 1.25$.

Trianon Cos, or Romaine. The heads are long and conical, often measuring 10 inches high by 18 inches in circumference. A short while before cutting, tie up the leaves, and they will blanch quickly and form solid heads, becoming as crisp as Celery stalks, tender and of excellent flavor. Pkt. 5c., oz. 15c., I + lb. $45 \mathrm{c}$., lb. $\$ 1.50$. 


\section{MUSK MELON, or CANTALOUPE}

Melox Miscade, Fr.

POPONE, Ital.

One ounce will plant 50 hills; tuco or three pounds for an acre.

Culture.-Som in light. rich, sandy soil after it has become warm and dry, in hills 5 to 6 feet apart, six to ten seeds in a hill. When up and all danger of insects has passed, pull out all but three plants. Pinch the ends of the growing rines to induce fruiting. Ashes, air-slacked lime or tobacco dust are excellent to sift over the young plants when the dew is on, to prevent attacks of insects.

\section{Schultz's "Money Maker"} Cantaloupe It has erery characCantaloupe should have, namely, blight or rust-resistant tendencr, a deadly disease which manifested itself in nearly every crop of Cantaloupes in past rears. Perfection in shape and size, being of the same shape as the old Rocky Ford. but slightly larger in size. In flavor it is deliciously siseet, hating a taste that is rich and luscious, being of the desired sweet. spicy flavor. The small carity, solidly filled with seed, a thick flesh, with smooth, firm texture. green in color and netting on the skin that outclasses anything yet introduced. The netting of a Cantaloupe such as this one enjors is a fanct feature. and without question is the essence of its appearance on the market. On the whole. it is an ideally perfect Melonone that will give absolute satisfaction to both the grower and consumer. Pkt. 5c. and 10c., 0z. 15c., 1/4 lb. 45c., lb. $\$ 1$.

\section{Schultz's Sweet Air This} green-fleshed Musk Melon has had a Wonderful reputation around Washington and Baltimore markets, and fully: deserves to be known over a mider territory. It grows very uniform in shape and size, averaging about 9 inches in length, from stem to blossoms, and 6 to 7 inches in the other direction; handsomely netted, very thick meat, with a delicious sweet flavor. Every Melon grower is to be congratulated whn plants a crop of this magnificent Melon, as it will be sure to please the grower, the merchant to whom it is sold. and the family for table

use. Pkt. 5c. and $10 \mathrm{c}$., oz. $25 \mathrm{c} ., 1 / 1 \mathrm{l} .75 \mathrm{c}$., 1h. $\$ 2.50$ growth, extra early, and very prolize. The fruits are ready for market filly as soon as the green-fleshed Early Jenny Lind. The firm, solid flesh is vert thick, of an attractive, deep salmon color and surpassingly sweet to the very
rind. It is already acknowledged by planters general$1 \mathrm{y}$ as decidedlr the best salmon-fleshed Melon to grow for market. The rines grom rigorously and each rine sets from five to nine. Melons immediately around the stem; frequently the fruits touch one another. The Melons are remarkably even in size. weighing from 1 lb. $80 \mathrm{oz}$ to $2 \mathrm{lbs}$. each. They are almays of the handsome form and attractive appearance. "Fordhook" produces practically no Melons unfit for market.

Rocky Ford. It is one of the finest early Melons and one of the best for market gardeners and shippers as well as for the home garden. It is oval in shape, slightly ribbed. and covered with coarse netting. The flesh is thick, green in color, very sweet and juicy, and solid clear to the rind. Pkt. 5c. and 10c., oz. 15c., 1/1 lb. 35c., lb. $\$ 1.00$.

Tip Top This very productive Melon is of large Ip Iop size, nearly round, slightly ribbed and fairly well cotered with shallow netting: skin light yellow when mature. The flesh is deep yellow in color, very rich and highly flavored. Pht. 5c. and 10c., 0z. 15 c., $1 / 4 \mathrm{lb}$. $35 \mathrm{c}$., lb. $\$ 1.00$.

Hackensack, Extra Early. Very early. Fruit is large and flattened. Ribs large and of irregular width, densely covered with coarse netting. Green flesh, thick and excellent flavor. Alwavs in demand in this market. Pkt. $5 \mathrm{c}$. and 10c., oz. $15 \mathrm{c} ., \frac{1}{4} \mathrm{lb} .35 \mathrm{c}$, lb. $\$ 1.00$.

New "Honey Dew" In the leading marmanded rery high prices the past season. Honey Ders produces a melon with smooth, almost white rind, measuring about 6 inches in diameter. seven to eight inches long. The green flesh is thick and is of a peculiar sweet flavor rers hard to describe. To hare the melons in the best condition Tre suggest gathering (or picking) as soon as they slip from the Tine and store in a cool place for two or three days before serving. They apparently are at their best when a trifle orerripe Please turn back to page for an accurate and fuller description. Pkt. jc. and 10 c., oz. $25 \mathrm{c} ., 1 / 4 \mathrm{lb} .65 \mathrm{c}$., lb. $\$ 2.00$.

Emerald Gem It is of a rich, delicious flavor and prolific; skin is striped deep emerald green with a fer light colored stripes. Flesh is very thick and salmon color. Exceedingly popular variety for market gardener or home use. F Ft. 5 c. and 10c., oz. 15c. $1 / 4$ ib. $35 \mathrm{c}$., 1b. $\$ 1.00$.

Jenny Lind. Green flesh, extra early and one of the sweetest in cultiration. Medium size. Pkt. 5c. and $10 \mathrm{c}$., 0z. $15 \mathrm{c} ., 1 / \mathrm{lb} .35 \mathrm{c} ., \mathrm{b} . \$ 1.00$.

Baltimore Nutmeg (Acme). Has a beautiful heavily netted green skin; good size: shape oval: slightly ribbed: fesh thich, green. very finely flavored. smooth lwars very sweet and most productive. Pkt. 5c., and 10c., oz. 15c., 111 lb. 35 c., lb. $\$ 1.00$

Petoskey, or Paul Rose. Tearly oval, slightly ribbed. netted; flesh thick and orange mlor. Pkt. 5c. and $10 \mathrm{c} ., 0 z .15 \mathrm{c} .01 / 4 \mathrm{lb} .35 \mathrm{c}$., lb. $\$ 1.00$.

\section{GARDEN GUIDE $\begin{gathered}\text { FOR } \\ \text { AMATEURS }\end{gathered}$}

A handbook giving full information how to plan, plant and maintain your Home Grounds, Suburban Garden and City Lot.

Price, Paper, 50c., Cloth, 75 c. 


\section{WATER MELON Meton D'enu, Fr.}

One ounce will plant about 30 hills; four pounds to the acre.

Culture.-Treat the same as Musk Melon, except that they should be planted 8 to 10 feet apart each way. Plant in light, rich, sandy soil.

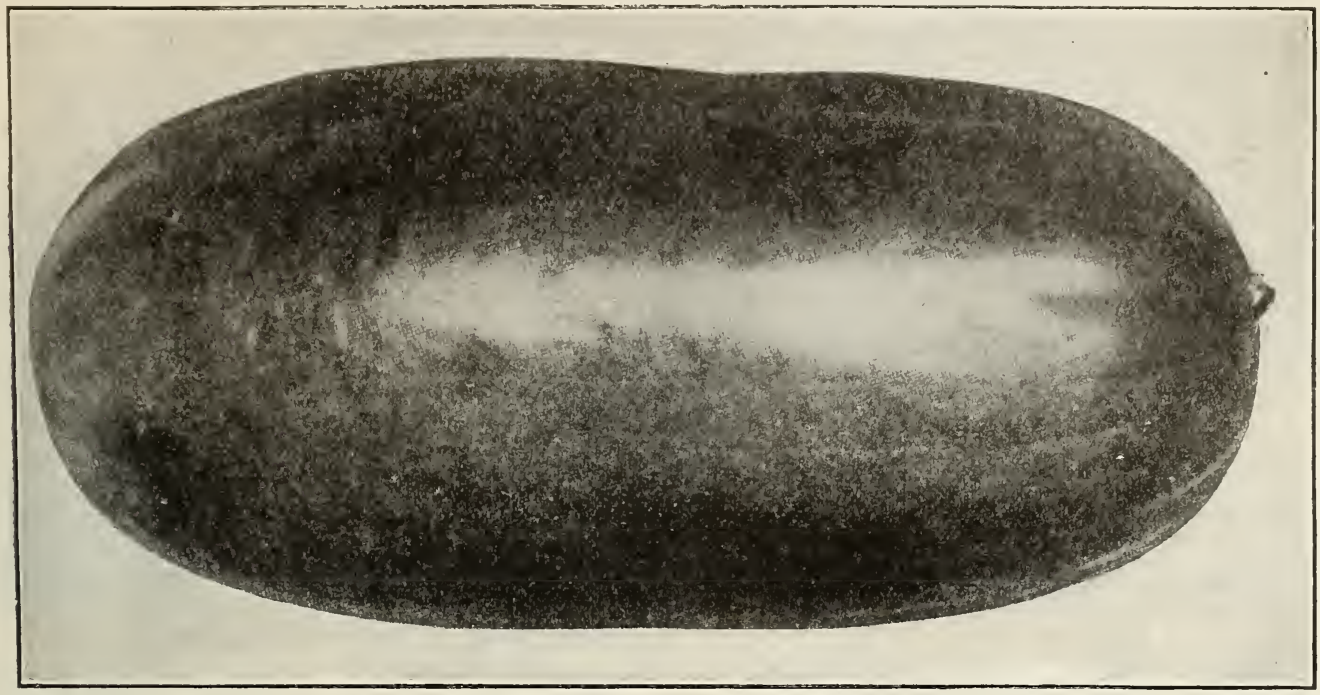

Tom Watson Water Melon

\section{Tom Watson Water Melon Fruit very} flavor most delicious. An extra long Melon of attractive appearance, uniform in shape and quality. The luscious crimson flesh is as "sweet as honey," melting, and of superb flavor. The average Melon will weigh 35 to 40 pounds and measure about 28 inches long and about 12 inches in diameter. It is very prolific, producing in greatest abundance the large, delicious fruits. (See illustration of specimen fruit above.) We have great faith in the Tom Watson and believe it is one of the very best Water Melons ever offered. Sure to take a leading place with large Melon growers and shippers. Pkt. 5c and 10c., oz. 15c., $1 / 4 \mathrm{lb}$. $25 \mathrm{c} ., \mathrm{lb} .85 \mathrm{c}$.

Halbert Honey A very sweet, long, dark age 18 to 20 inches long, have a thin rind and deep red meat of delightfully delicious flavor; pulp entirely free from stringiness; seeds white. One of the finest for the home garden. Pkt. 5c. and 10c., oz. $15 \mathrm{c} ., 1 / 4$ lb. $25 \mathrm{c} ., 1 \mathrm{~b} .75 \mathrm{c}$.

\section{Monte Cristo, or Kleckley's Sweets}

Unsurpassed for home use or near markets. Vine vigorous and productive; fruit medium to large, oblong, tapering slightly toward the stem end, dark green, often showing fine russeting. Flesh very

- bright, rich red, exceedingly sweet. So crisp and tender that it will not stand shipping, the fruit bursting open if subjected to even a slight jar, or when the rind is penetrated with a knife. Seel white. Pkt. 5c. and 10c., oz. 15c., $1 / 4$ lb. 30c., lb. 9cc.

Florida Favorite A splendid Melon of very quality. Fruit long, dark green, mottled and striped with lighter shade; rind thin but firm. Flesh yery bright, deep red, very sweet and tender. Vines vigorous and productive. Seed white. Pkt. 5c., and $10 \mathrm{c}$, , oz. 15c., $1 / 4$ lb. $25 \mathrm{c}$., lb. $75 \mathrm{c}$.

Sweet Heart. Vine vigorous and very productive, ripening its fruit evenly. Fruit of largest size, oval, very heavy, rind thin but firm; color very light green, very slightly veined with a little darker shade. Flesh bright red, firm, but very tender and sweet. Fruit remains in good condition a long time after ripening. Fine for home use or shipping. Pkt. $5 \mathrm{c}$. and 10c., oz. 15c., 1/4 lb. 20c., lb. 65c.
Gypsy, or Georgia Rattlesnake. One of the largest ldest and most popular sorts. Fruit very long, of light green color, distinctly striped and blotched with a darker shade. Flesh bright scarlet, very sweet and tender. Vines large and vigorous. Pkt. 5c. and 10c., oz, 15c, $1 / 4$ lb. 20c. lb. 65 c

Gray Monarch, or Long Light Icing. Fruits uniformly long and large, a little irregular in shape, light green, slightly veined with a little darker shade. Flesh deep, rich red, and of splendid quality. Seed white. Pkt. 5c. and 10c., oz. 15c., $1 / 4$ lb. 25c., lb. $75 \mathrm{c}$.

Citron. Medium size, uniformly round, used only for preserves or pickles. Color dark green, distinctly striped and marbled with light green. Flesh white and solid, but not at all suitable for eating raw. Seed red. Pkt. 5c. and 10c., oz. $15 \mathrm{c}$., $1 / 4$ lb. $25 \mathrm{c}$., lb. $85 \mathrm{c}$.
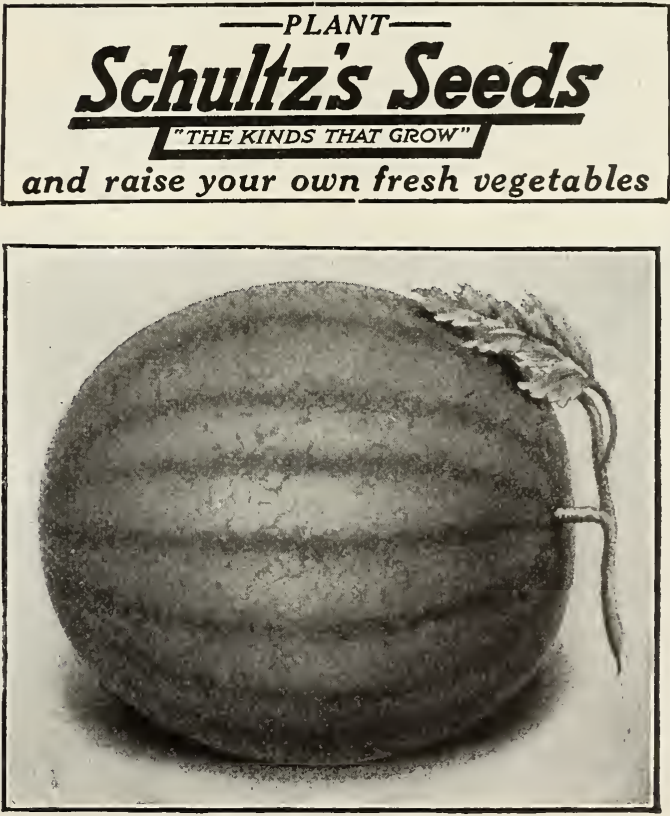

Citron Water Melon 
22 Schultz's Seed Store, Washington, D. C.

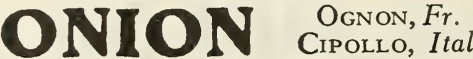

An ounce will sow 100 feet of drill; four to five pounds to the acre.

Culture.-Sow in rich soil, in drills 1 foot apart, as soon as the ground can be worked in the Spring; thin out to 2 inches apart in the row, carefully keeping down the weeds. The finest Onions are produced by sowing the seed in a hotbed in February or March, and transplanting the seedlings to the open ground 3 to 4 inches apart, in April. For sets, sow the seeds as early as possible in the Spring, very thickly, in drills as soon as the tops die off in Summer remove them to a dry, airy place; and early in the following Spring replant by placing the sets in shallow drills, 12 inches apart, and 2 inches apart in the drills.

\section{Silver Skin, or White Portugal}

This variety is one of the leading white sorts and is of beautiful shape and very mild flavor; the bulbs are flat in shape and mature early. It is a splendid variety for both family use and the market garden, and is very largely used for growing sets on account of its fine shape when small and also for its good keeping qualities. It is also extensively used as a pickling Onion, for which purpose it seems to be finely adapted. Pkt. 5c. and 10c., oz. 25c., $1 / 4$ lb. 65c., lb. $\$ 2.25$.

Southport White Globe The handsomest beautiful silver skin, perfect globe shape. Forms handsome, hard Onions with wax-like, pearl-white flesh. Is used a great deal for green Onions owing to the clear white stem. Pkt. 5c. and 10c., oz. 25c., $1 / 4$ lb. 75 c., lb. $\$ 2.50$.

Mammoth Prize-taker, or Spanish

This is the large pale vellow Onion that is offered for sale in the fruit stores and markets in the Fall. It grows to a very large size, flesh white, of mild and delicate flavor. Tie large Onions are raised the first year from seed, and with ordirary culture, produce enormous crops. Pkt. 5c. and 10c., oz. 20c. $1 / 4$ lb. 60c., lb. $\$ 2.00$.

Southport Yellow Globe A fine, orange shaped variety Is a heavy yellow, globelong-keeping, hard bulb. Pkt. 5c. and 10c., oz. 25c., $1 / 4 \mathrm{lb}$. $75 \mathrm{c}$., lb. $\$ 2.25$.

Yellow Globe Danvers A standard sort most desirable. An excellent keeper and very productive. Our strain of this variety is the true globe shape. Pkt. 5c. and 10c., oz. 20c., 1/4 lb. 50c., lb. $\$ 1.50$.

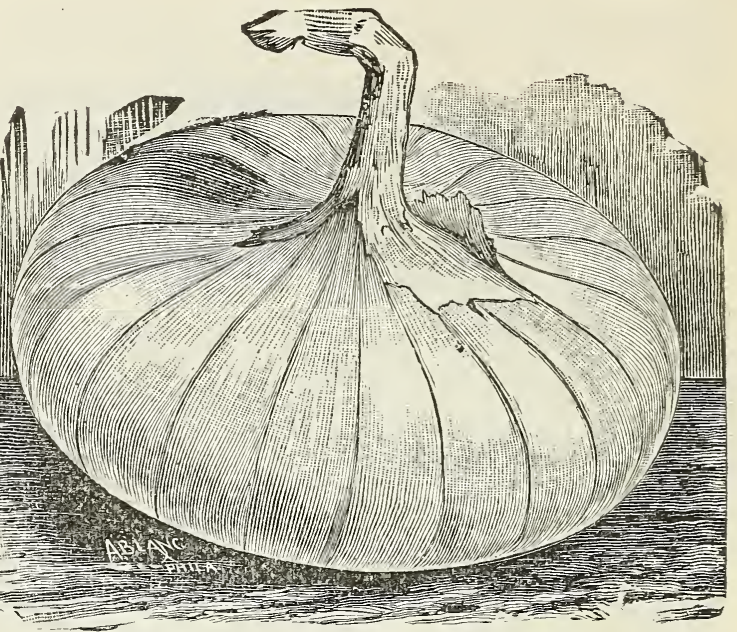

Silver Skin, or White Portugal Onion

Large Red Wethersfield. Large; skin deep purplish red; form round, somewhat flattened; flesh purplish white; moderately fine grained and stronger flavored than any of the other kinds. Pkt. 5c. and 10c., oz. 20 c., $1 / 1$ lb. 60 c., lb. $\$ 2.00$

Australian Brown. The bulbs are perfectly globeshaped; quick to mature; a long keeper, solid and heavy, Pkt. 5c., oz. 20c., $1 / 4$ lb. 60c., lb. $\$ 2.00$.

\section{CHOICE ONION SETS}

Prices subject to market changes One quart will plant 40 feet of row; eight to ten bushels per acre according to size of sets.

Culture-Onion sets should be planted out as early in the Spring as the ground is dry enough to work; plant them in rows 1 foot apart, with sets 2 inches apart in the row.

Yellow. Pt. 15c., qt. 20c., 4 qts. 65c., pk. $\$ 1.00$, bus $\$ 3.00$.

White. Pt. 15c., qt. 25c., 4 qts. 75c., pk. $\$ 1.25$, bus. $\$ 4.25$.

Red. Pt. 10c., qt. 20c., 4 qts. 65c., pk. $\$ 1.00$, bus $\$ 3.00$.

Yellow Potato. Pt. 15c., qt. 25c., 4 qts. 90c., pk. $\$ 1.50$.

Egyptian, or Perennial Tree. Pt. 10c., qt. 15c., 4 qts., $40 \mathrm{c} .$, pk. $65 \mathrm{c}$. , bus. $\$ 2.00$.

When larger quantities of Onion Sets are desired, write for prices.

\section{Great Labor Savers}

Wheel Hoe with their attachments for cultivating, hilling, covering, etc. They enable a man to care for five times the area that can be done by "the man with the (other) hoe" See pages 50 and 51. 


\section{PARSLEY Persil, Fr. \\ One ounce will sow 100 feet of drill.}

Culture.-Parsley seed germinates very slowly, taking two to four wreeks to come up; hence; if wanted early, no time should be lost by delaying the sowing. Make the rows 12 to 14 inches apart. Thin to 3 or 4 inches apart, or transplant at this distance. Can be sown in hotbeds in February, or later in open ground. Late in Autumn place frames over some of the plants to lengthen out the season of cutting. For garnishing purposes nothing equals Parsley; it is also used in salads, soups, etc. Any good soil will suit for growing this plant.

\section{Schultz's Selected Triple Curled}

A distinct and handsome variety of quick robust growth forming compact, ornamental plants, densely furnished with strong-stemmed graceful leaves, finely cut, most beautifully curled, and of that brilliant emerald green color so highly attractive when used for garnishing. The flavor of the leaves is also unusually rich and aromatic, rendering this variety of special value where used for flavoring in sauces, dressing, etc., either when fresh or dried. (See cut.) Pkt. 5c. and 10c., oz. 15c., 1/4 lb. 35c., lb. $\$ 1.25$.

Champion Moss Curled. Leaves are of exceedingly dark green color, very finely curled, making it most attractive for garnishing, while the plant is very attractive as a border. Pkt. 5c. and 10c., oz. 15c., $1 / 4$ lb. 35c., lb. $\$ 1.25$.

Double Curled. Very robust, free growth. Leaves are large, very dark green and beautifully curled. Pkt. 5c. and 10c., oz. 15c., 1/4 lb. 30c., lb. $\$ 1.00$.

Plain Leaf. Leaves are longer and darker green than the curled varieties; very hardy. Excellent for seasoning. Pkt. 5c., oz. 15c., 1/4 lb. 25c., lb. $75 \mathrm{c}$.

\section{PARSNIP}

One ounce will sow 100 feet of drill.

Culture.-Sow in Spring as soon as the weather will permit in rows 18 inches apart. Cover seed $1 / 2$ inch deep; thin out to 5 inches apart in row when plants are large enough. A little frost improves the flavor. Take up what is wanted for Winter, leaving the rest in the ground for Spring.

Perfect Hollow Crown $\begin{gathered}\text { This is a highly } \\ \text { improved }\end{gathered}$ producing uniformly large and handsome roots of stocky form, heavy at the shoulder, perfect hollow crown. The roots are smooth and free from wrinkles and side roots. The flesh is white, of fine texture,

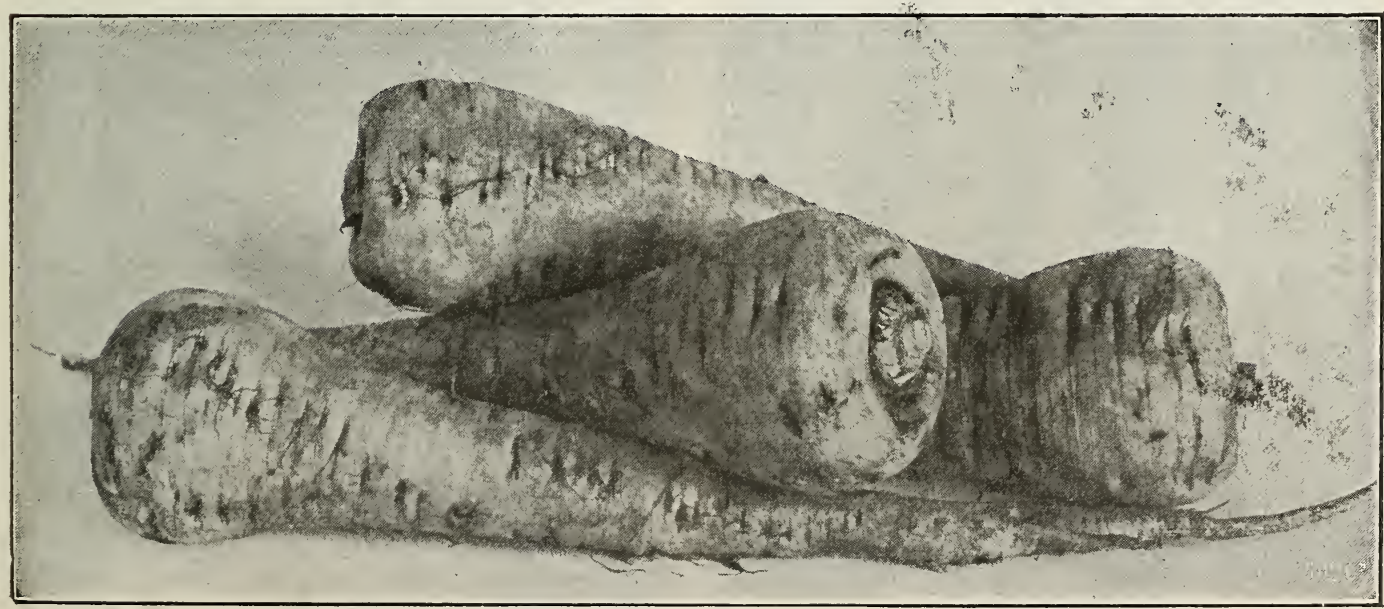

Perfect Hollow Crown Parsnip 
Prices subject to change without notice.

One quart will plant 100 feet of row; from one to two busheis per acre.

Culture.-Peas mature earliest in a light, rich soil; for general crop, a rich, deep loam is best. Sow in double rows 6 to 8 inches apart, the rows 2 to 4 feet apart, the tall ones requiring brush. Commence sowing the extra early varieties as early as the ground can be worked in February or March; continue for a succession every two weeks until June, then discontinuing until the middle of August, when a good crop may be secured by sowing the extra early and early sorts for Fall use. They should be kept clean and earthed up twice during the growth. The wrinkled varieties are not as hardy as the small, round sorts, and if planted early should have dry soil, or they are liable to rot in the ground; they are, however, the sweetest and best flavored varieties. The dwarf varieties are best suited for small gardens, planted in rows 1 foot apart.

\section{Extra Early Varieties}

Schultz's Big Marvel This is the earliest large-podded Pea in cultivation. - The peas are tender, sweet, of extra size; pods average 5 inches long and contain from seven to nine peas of enormous size and excellent quality. Height 2 feet. Pkt. 10c., pt. 35c., qt. 60c., 4 qts. $\$ 2.25$, pk. $\$ 4.00$, bus. $\$ 13.50$.

Laxtonian A new dwarf Gradus. This is the Laxtonian largest podded of all the early dwarf varieties and is a new sort of decided merit. The vines are vigorous, growing about 16 inches high and produce a large crop of good-sized pods, averaging from 9 to 10 peas to the pod. The peas are of exquisite flavor and mature early. Many people who have tried Laxtonian consider it superior to either Gradus or Thomas Laxton, and claim it to be the best of all the early dwarf sorts. It is certainly worth a trial. Pkt. 10c., pt. 35c., qt. 60c., 4 qts. $\$ 2.25$, pk. $\$ 4.00$, bus. $\$ 13.50$.

\section{Extra Early Pilot Can be planted fully} Gradus, withstanding the cold, wet grounds without rotting, and while not a wrinkled sort, the pods and peas are almost equal in size and flavor to Gradus. The vines, which are vigorous in growth, attain a height of 3 feet. Pkt. 10c., pt. 30c., qt. 60c., 4 qts. $\$ 2.00$, pk. $\$ 3.50$, bus. $\$ 12.00$.

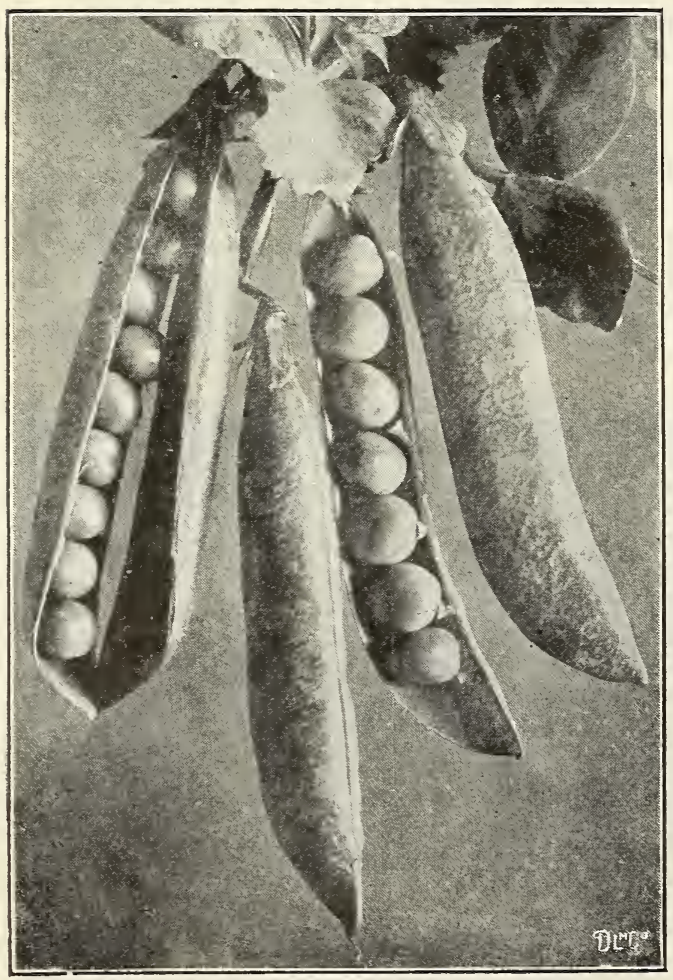

New Wonderful Peas
New Wonderful The earliest and most productive of all extra early frowth, and produces an abundance pods, filled with deliciously sweet Peas. It is fully as early as Alaska. Pods are usually larger, with more of them per plant, and it has decided advantage in being more hardy; being a round-seeded varietv, it may be sown earlier. Height 3 feet. (See illustration foot of page). Pkt. 10c., pt. 30c., qt. $60 \mathrm{c}$., $1 / 2$ pk. $\$ 2.00$, pk. $\$ 3.50$, bus. $\$ 12.00$.

Market Surprise It is extremely early, prodance which are filled with luscious green Peas. The robust growing vines grow $21 / 2$ feet high, which require no staking. The peas are ready for picking a week ahead of Prosperity or Gradus, producing pods which contain eight to nine fine peas of rich green color. This is the pea that all progressive gardeners are looking for as it is very hardy, extremely early, large podded and a prolific bearer, making it a quick basket filler. The peas are of excellent flavor, sweet and delicious. Pkt. 10c., pt. 30c., qt. 60c., 4 qts. $\$ 2.00$, pk. $\$ 3.50$, bus. $\$ 12.00$. Little Marvel For the earliest crop this variety Ironder or Nott's Excelsior, as it matures earlier and the pods contain more peas. It is dwarf, growing about 15 inches high and the plants are very productive, bearing many twin pods, which are dark green in color. Pkt. 10c., pt. 35c., qt. 60c., 4 qts. $\$ 2.25$, pk. $\$ 4.00$, bus. $\$ 13.00$.

Alaska, or Earliest of All A wonderfully small-podded, extremely early sort. The vines, of a peculiar distinctive, light green tinge, are $21 / 2$ to 3 feet high. Pods are dark green, $21 \frac{1}{2}$ inches long, straight, round and well filled with small, smooth, blue-green Peas of good flavor. This Pea matures an abundance of pods and is invaluable to the private gardener. Pkt. 10c., pt. 25c., qt. 50c., pk. \$2.50, bus. $\$ 9.00$.

Gradus or Prosperity. The most popular of the Gradus long, large podded, wrinkled Peas. Of the finest quality and matures pods only a few days later than the extra early smooth Peas. Vines grow about $21 / 2$ feet high, very large. Are of superior quality in size and flavor. Always salable as a market variety. Pkt. 10c., pt. $35 \mathrm{c}$. qt. $60 \mathrm{c} ., 4$ qts. $\$ 2.25$, pk. $\$ 4.00$, bus. $\$ 13.50$.

Thomas Laxton This splendid English variety closely resembles the Gradus in habit and rapidity of growth, earliness and luxuriance of foliage. It is however even more productive than the Gradus, and has proved to be a sure cropper. The pods are large, square or blunt, being even better filled than the Gradus. Height 3 feet. Pkt. 10c., pt. 35c., qt. 60c., 4 qts. $\$ 2.25$, pk. $\$ 4.00$, bus. $\$ 13.00$.

American Wonder. Excellent for family use. Height 12 inches. Pkt. 10c., pt. 30c., qt. 60c., pk. $\$ 3.50$, bus. $\$ 12.00$.

Nott's Excelsior. Vines dwarf in habit, wonderfully productive. Height 12 inches. Pkt. 10c., pt. 30c. qt. 60 c., pk. $\$ 3.50$, bus. $\$ 12.00$.

Premium Gem. Bears abundantly; sweet and tender. Height 12 inches. Pkt. 10c., pt. 30c., qt. 60 c., pk. $\$ 3.50$, bus. $\$ 12.00$. 
GARDEN PEAS-Continued

\section{Second Early and Late Sorts}

British Wonder Even swecter in flavor than either Gradus or Thomas Laxton. The growth is similar to Dwarf Telephone, except that the foliage is darker green and pods are not so sharply pointed. It is however, much more reliable, as it is a sure cropper. The vines grow from 15 to 18 inches high. The pods are produced most abundantly and uniformly well filled with large, dark green Peas. The Peas mature a little earlier than Stratagem. Pkt. 10c., pt. 30c., qt. 60c., 4 qts. $\$ 2.00$, pk. $\$ 3.50$, bus. $\$ 12.00$.

Schultz's Top Notcher Medium late, long, Schultz's Top Notcher dark green pods, sweet, tender and luscious. An improved Telephone; very useful for exhibition. One of the finest Peas ever put on the market. A customer said: "Next year, I shall grow only two Peas, and one is Top Notcher." Height 5 feet. Pkt. 10c., pt. 30c., qt. 60 c., $1 / 2$ pk. $\$ 2.00$, pk. $\$ 3.50$, bus. $\$ 12.00$.

Champion of England A standard, very crop variety, universally admitted to be one of the richest and best flavored of the late Peas. The vigorous vines are 4 to 5 feet high, foliage medium green, pods about 3 inches long, blunt, medium dark green in color, broad, and nearly straight. Our stock of this Pea is a fine one. Pkt. 10c., pt. 30c., qt. 60c., pk. $\$ 3.50$, bus. $\$ 11.00$

Prince Edward The giant of the Pea family, the extraordinary length of 6 inches and upward, closely packed with 9 to 11 large, dark green Peas of fine flavor. The plant is of branching habit, 6 feet in height, with dark green folkage. It is of a very vigorous and robust constitution. The pods are produced in great profusion, mostly in pairs. Pkt. 10c., pt. 30 c., qt. 60 c., 4 qts. $\$ 2.00$, pk. $\$ 3.50$, bus. $\$ 12.00$.

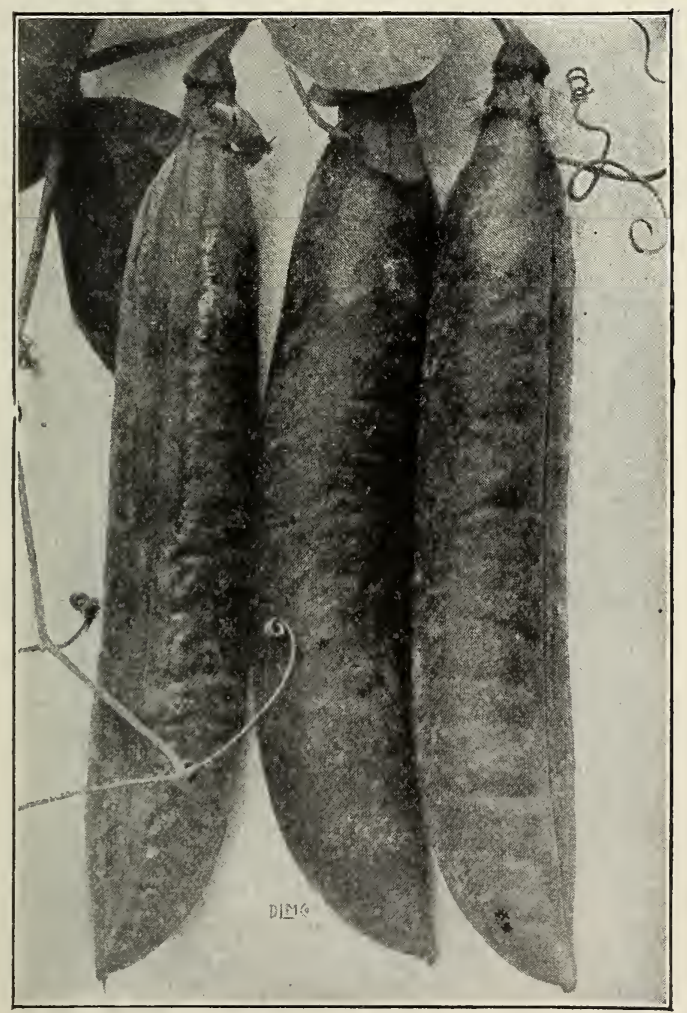

Telephone Peas

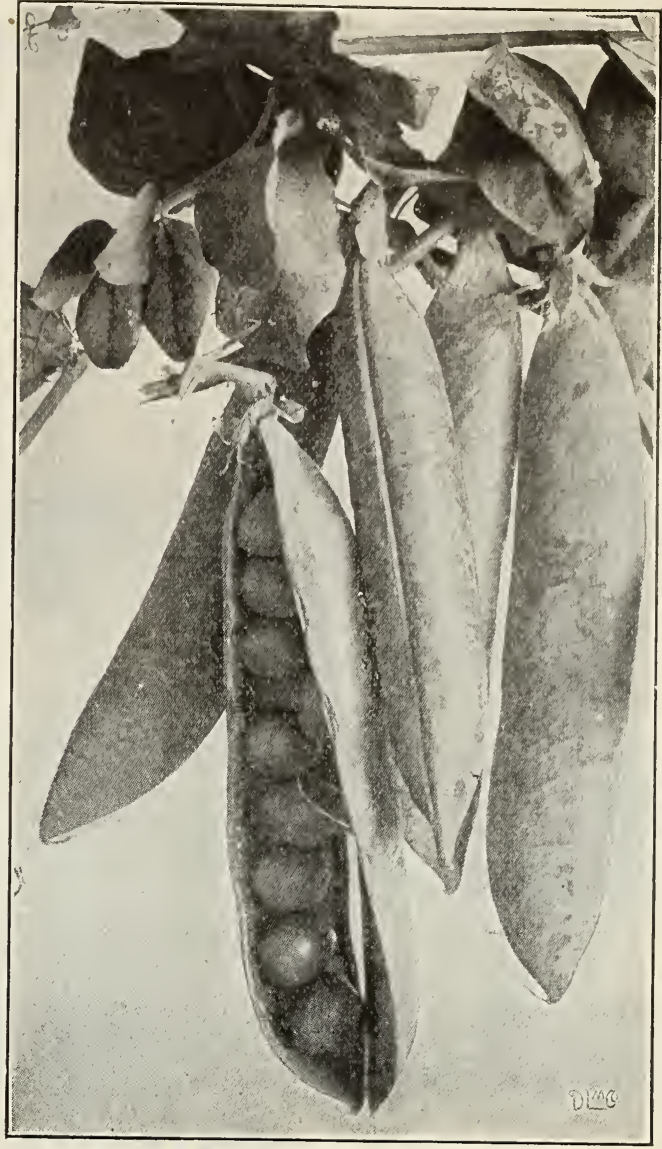

British Wonder Peas

Telephone The favorite late variety for the pods. Vine large, coarse leaves, height about 4 feet. The pods are very large and filled with immense Peas. Tender, sweet and of splendid quality and flavor. Pkt. 10c., pt. 30c., qt. 60c., pk. $\$ 3.50$, bus. $\$ 12.00$.

Mammoth Podded Sugar (Edible pods). grows to the height of 5 feet; bears a profusion of very large, broad, handsome, light green (nearly white) pods, which are so brittle that they snap without any strings. Sweet, tender and of excellent flavor. Pkt. 10c., pt. 35c., qt. 60c., gal. $\$ 2.25$, pk. $\$ 4.00$.

\section{NOTE}

Our Big Marvel and New Wonderful Peas are so well known and are so much sought after that other firms are offering Peas under their names. We have tested many of these and find some entirely untrue and others of inferior strain. $\mathrm{Be}$ sure to get out highly selected type, which are procurable only direct from us.

S. S. S. 
One ounce will produce about 1500 plants.

Culture.-Sow in hotbed in March or April; transplant in open ground in May when all danger from frost is over, in rows 3 feet apart and 2 feet apart in a row. Seed can be sown outsice late in May. Cover seed $1 / 2$ inch and thin as above.

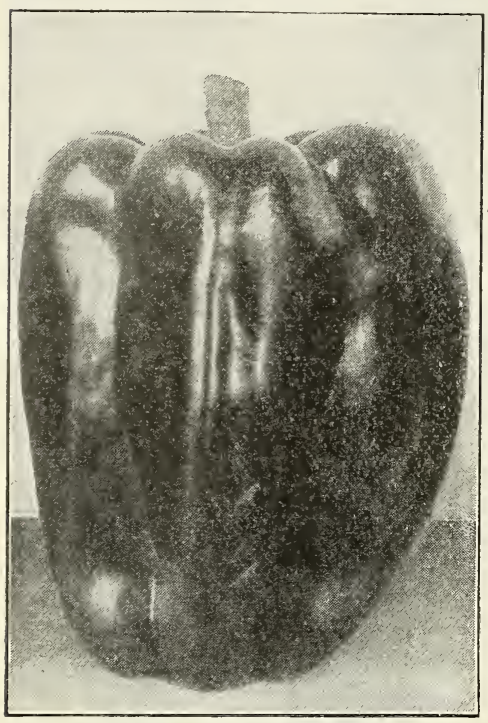

Chinese Giant Pepper

Schultz's Selected Chinese Giant Double the size this is one of the largest and finest mild red P of Puby King, this is one of the largest and finest mild red Peppers. Not only is it intensely productive, but it is as "sweet as an Apple," and unusually thick skinned. Pkt. 5c. and 10c., oz. 50c., 1/4 lb. $\$ 1.75$, lb. $\$ 6.50$.

Ruby King These are a bright ruby color, remarkably mild Ring and pleasant. Can be sliced and eaten with vinegar and pepper, used as a salad, or stuffed with Mangoes. The fruit is from 4 to 6 inches long. Pkt. 5c. and 10c., oz. 50c., $1 / 4 \mathrm{lb}$. $\$ 1.50, \mathrm{lb} . \$ 5.00$.

Pimiento This the sweetest Pepper grown, as it does not conextremely productive, and Peppers are medium in size and of a shape which is desirable for filling, and when prepared in this manner they are delicions. It may also be used in preparing salads and for flavoring, in which case it will add a fresh and delightful flavor. The flesh is quite thick and the Pepper may be scalded for peeling the skin off. When fully ripe the Peppers are of a brilliant red color and very attractive. Pkt. 5c. and 10c., oz. 50c., 1/4 lb. $\$ 1.50,1 b . \$ 5.00$.

Large Bell, or Bull Nose Very large, nearly 4 inches Large Bell, or Bull Nose long and 3 inches in diameter; glossy red. Excellent for use in salads or pickles. Pkt. 5c. and $10 \mathrm{c} .$, oz. $45 \mathrm{c} ., 1 / 4 \mathrm{lb} . \$ 1.50,1 \mathrm{~b}$. $\$ 4.50$.

Long Red Cayenne Bears an abundance of long bright ling when both green and ripe. Very strong and pungent. Pkt. 5c. and 10c., oz. $45 \mathrm{c}$., $1 / 4$ lb. $\$ 1.35$, lb. $\$ 4.50$.

Golden Queen. Bright golden-yellow color. Mild and sweet. Pkt. 5c. and 10c., oz. 40c., $1 / 4 \mathrm{lb}$. $\$ 1.50$.

Red Chili A variety used for Pepper sauce. The bright red rich pods are about 2 inches long, onethird to one-half inch at the base, tapering to a sharp point and exceedingly pungent when ripe. Pkt. 5c. and 10c., oz. 45c., $1 / 4$ lb. $\$ 1.35,1 \mathrm{~b} . \$ 5.00$.

Cherry Red. Small, smooth, round variety. Deep, glossy, scarlet color. Pkt.5c. and 10c., oz. 40c., 1/4 lb. $\$ 1.50$.

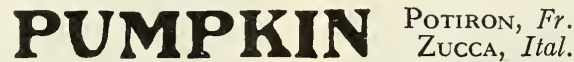

One ounce will plant about 20 hills, one pound will plant 200 to 300 hills.

Culture.- Sow when all danger from frost is over in hills 8 feet apart; thin out to four plants in a hill. The common practice is to drop two or three seeds in every third or fourth hill in the corn field.

King of the Mammoths The flesh and skin are of a bright golden-yellow color. Flesh fine grained, ing of the Mammoths and of excellent quality. Notwithstanding its enormous size, it is one of the very best pie Pumpkins ever grown, and a splendid keeper. This enormous variety has been grown to weigh 200 pounds. Pkt. 5c. and 10c., oz. 15c., $1 / 4$ lb. 35c., lb. $\$ 1.25$.

\section{Burpee's Golden Oblong Very hardy and} to 20 inches in length and 8 to 10 inches in diameter. Skin of a rich golden orange, thin but tough, making it almost as good a keeper for Winter as the hardshell squashes. Flesh is light golden yellow, of a very rich, fine quality. Pkt. $5 \mathrm{c}$. and 10c., oz. $15 \mathrm{c} ., 1 / 4 \mathrm{lb}$. 35 c., lb. \$1.25.

Small Sweet, or Sugar A very fine-grained sweet-flavored Pumpkin, also a splendid keeper all through the Winter. For size they average about 10 inches in diameter, and being of a round, flattened shape and deep orange color. Pkt. 5c. and 10c., oz. 15c., $1 / 4$ lb. 35c., lb. $\$ 1.00$.

\section{Large Cheese, or Kentucky Field}

One of the best for table use and very productive. Shape flat; skin mottled light green or yellow, changing to a rich cream color; flesh yellow, thick and tender. Pkt. 5c. and 10c., oz. 15c., 1/4 lb. 35c., lb. $\$ 1.00$.

Golden Crookneck The old standard and Cropular Crookneck Pumpkin. They are rich, dark golden yellow in color, thick meated, fine fleshed. Pkt. 5c. and 10c., oz. $15 \mathrm{c} ., 1 / 4$ lb. 35c., lb. $\$ 1.25$.

Connecticut Field The hardiest of all Pumpstock feeding, producing enormous crops. Pkt. 5c. and $10 \mathrm{c}$, oz. $15 \mathrm{c} ., 1 / 4 \mathrm{lb} .35 \mathrm{c} ., \mathrm{lb} . \$ 1.00$.

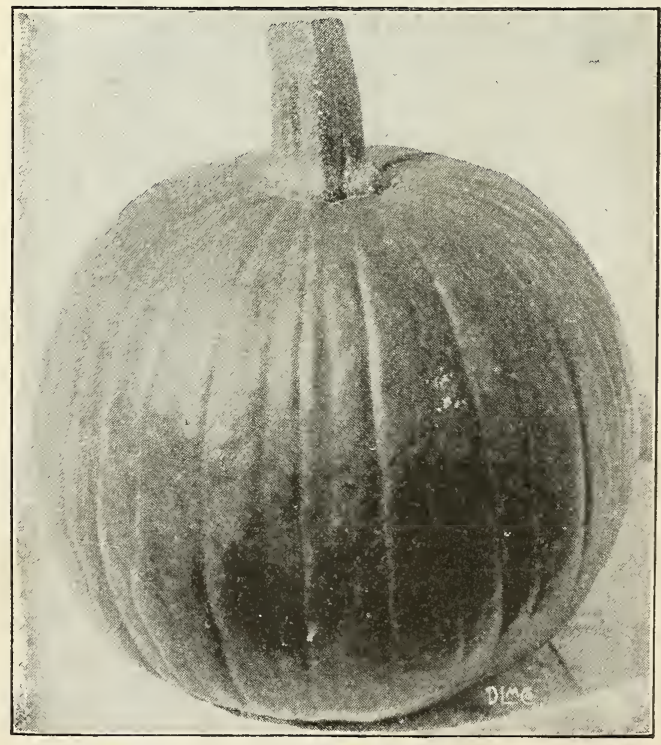

Small, Sweet, or Sugar Pumpkin 


\section{POTATOES}

Seed Potatoes weigh 165 pounds to the barrel, net.

Eight to ten bushels, or three to four barrels sufficient for one acre; one peck will plant 100 hills.

Culture.-Any good soil will produce Potatoes, but quality is much inmproved when produced on good, sandy loan. Make furrows of good depth, 3 fect apart, scatter a liberal dressing of fertilizer in the drill. ('over slightly with earth and upon this set the seed Potatoes in bills 12 inches apart. If a very early crop is desired, it will be necessary to sprout the Potatoes before planting. Cut the Potatoes in pieces of the size desired and place in warm, light room for four days before required for planting in the open ground.

Use Bordeaux mixture for blight and arsenate of lead for the Colorado beetle, or if, as is often the case, both these conditions prevail, use the two in combination.

IMPORTANT-We cannot make prices at this writing, but will be glad to quote prices upon application.

Our Potatoes are strictly Maine grown, and especially for seed. We make a special price on large quan tities.

\section{A CHANGE OF STOCK \\ SEED IS A GREAT BENEFIT}

Though Potato growing is one of the main industries of our country, many farmers think that all that is necessary is to plant any seed on any soil and harvest the crop, blaming the season for poor yield. Some reasons for poor crops are want of good seed, care, cultivation and fertilizing. Change of stock seed also is one of the requisites neressary to success; any one variety of Potato loses both in quality and yield by growing from the same strain of seed every year; so a change is desirable. A farmer should also be constantly experimenting with new varieties, and find out which are best adapted to his needs and soil.

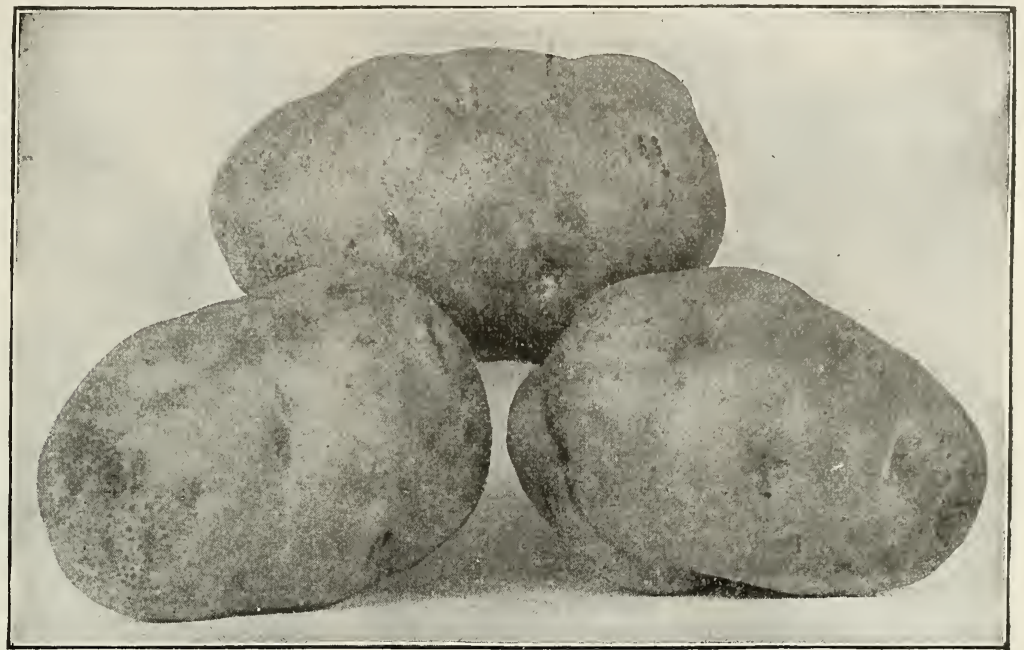

Irish Cobbler Potato
Irish Cobbler Excellent yielder. Tubers a beautiful creamy white; eyes strong, well developed, and but slightly indented flesh white and skin often netted. Quality fine. Its handsome appearance, perfect form and superb cooking qualities will readily recommend it to every grower.

Double X Early One of the earliest and seedling of the Early Rose. The tubers are oblong oval, round at the seed end, with eyes that are almost even with the surface. An excellent keeper, very productive, of fine quality, and has proved to be a most valuable addition to our list of extra early varieties.

New Queen It is about a week later than the of most superior flavor and desirable for private growers and the home market.

Early Ohio Round, oblong, smooth tubers: very early, of fine quality.
Green Mountain Large, 'handsome, white Potato, a prolific yielder fine eating quality, cooking dry and mealy. It is medium early and gives excellent results on all kinds of soil. The flesh is very white with a flavor all its own.

Houlton Early Rose This variety is too a description. After inany years it is still as popular as ever, and when you purchase the Pure Early Rose, true to name, such as we offer, you obtain a variety that you cannot surpass for all general purposes.

White McCormick A selection from the Pink McCormick Potato. Has a pure white skin and flesh. A heavy vielder and one of the best general crop Potatoes. Fine keeper and growing very popular with the truckers.

Pink McCormick A very popular late sort; in fact, too well known for us to describe. Plant along in June or July and you will receive a yield that will surprise you.

\section{Seed Sweet Potatoes}

Prices subject to change.

Culture.-Put the Potatoes in hotbeds in April, covering with 3 inches of earth and after they begin to grow give plenty of air on sunny days and water regularly. In May or June set out 15 inches apart in rows 3 feet apart. The land should be plowed shallow in order to produce the short, chunky Potato most largely in demand.

Big Stem One of the best market varieties; a large yielder and of good flavor. Bright yellow. Pk. 50c., bus. $\$ 1.50$.

Nancy Hall The best variety for home or market, fine quality, good yielder, yellow skin and flesh. Pk. 50c., bus. $\$ 1.50$.

SWEET POTATO PLANTS. Rooted slips ready in May. The young plants should be set in May and June. A light soil and sunny location are preferable. Per $10040 \mathrm{c} ., 1000 \$ 2.50$. Special prices on large lots. 


Schultz's Seed Store, Washington, D, C.

\section{RADISH Radis, Fr.}

One ounce will sow about 100 feet of row.

Culture.-Sow in the open ground as soon as it can be worked, at intervals of ten days for a succession as long as wanted. Sow in hotbed or greenhouse in Autumn and Winter. The Winter varieties should be sown in August and lifted before severe frost. As their tender and mild qualities depend on rapid growth, the soil should be rich, light and mellow.

Schultz's Scarlet Globe-shaped The color, a rich For foring or scarlet. rariety are slightly olive-shaped, a rich, bright scarlet in color; flesh white and tender, fit to pull as early as any Radish that grows. We especially recommend this to gardeners whose markets demand a large, first-early forcing Radish. It is also very desirable for first early planting outdoors. Pkt. $5 \mathrm{c}$. and $10 \mathrm{c.}, \mathrm{oz}$.

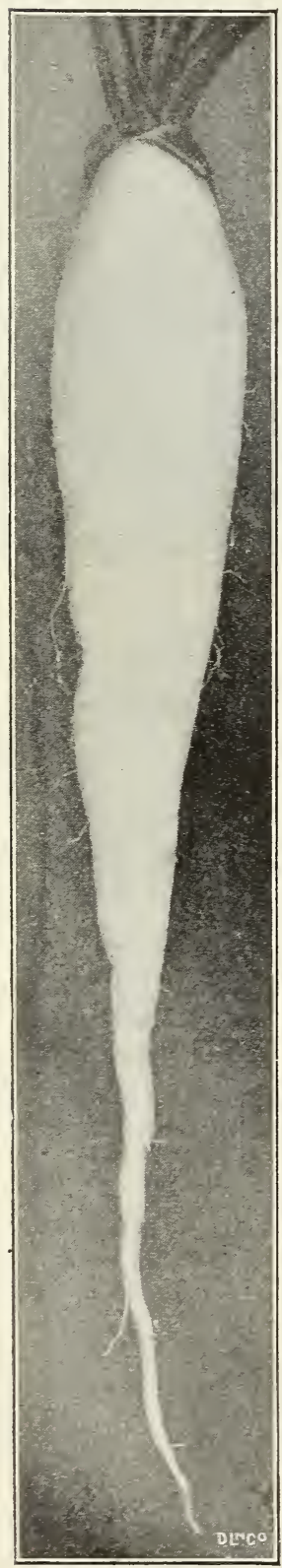

Icicle Radish

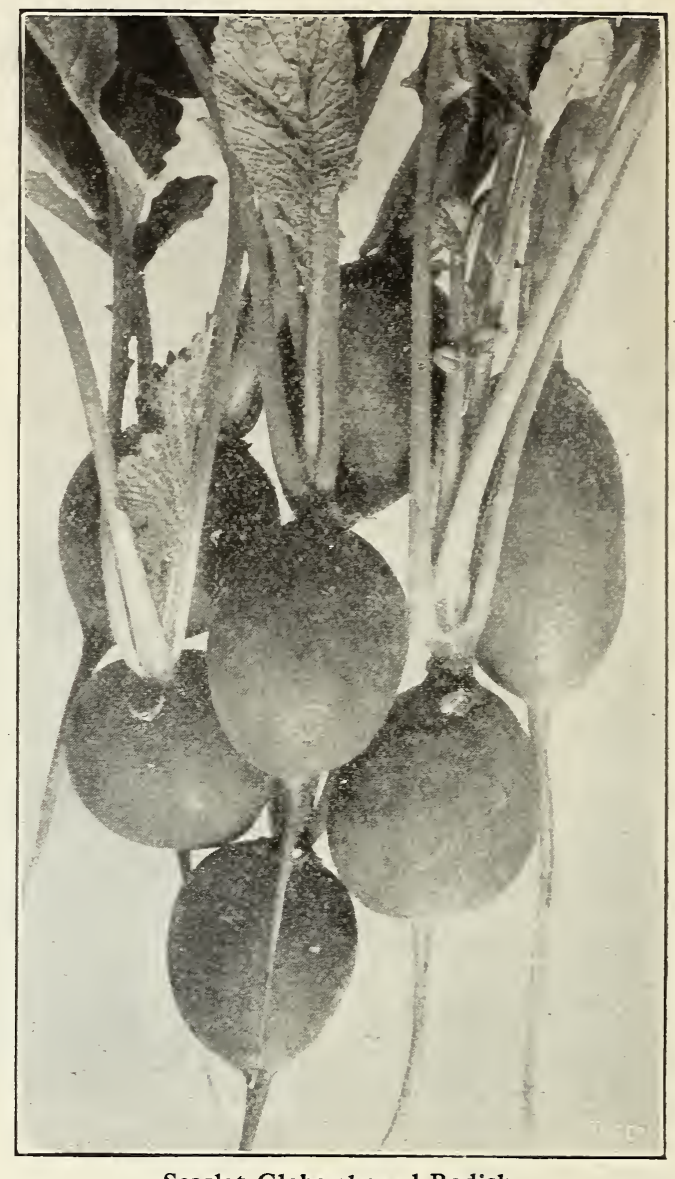

Scarlet Globe-shaped Radish

\section{Scarlet Turnip} White Tipped

One of the most popular and attractive short rarieties. It is globe-shaped, bright rose carmine with bottom.and tip clear white. Pkt. 5c., oz. 15c., $1 / 4$ lb. 35c., lb. $\$ 1.00$.

Vick's Early Scarlet Globe. Admirable for forcing or out-of-door culture: deep scarlet; flesh white and tender. Pkt. 5c., oz. 15c., 1/4 lb. 35c., lb. $\$ 1.00$.

Crimson Giant This variety will grow a medium size as quickly as any; it Pkt 5e. 15c. also remains crisp, firm and solid until double the size of others.

White Box Turnip-shaped, pure white Radish; early; fine for forcing and outWhite Box doors. Pkt. 5c., oz. $15 \mathrm{c}$., $1 / 4 \mathrm{lb}$. 35c., lb. $\$ 1.00$.

Long White Vienna, or Lady Finger. A long white variety; very crisp and tender; grows to good size; matures early. Pkt. 5c., oz. 15c., 1/4 lb. 35c., lb. $\$ 1.00$.

Golden Globe. Yellow skin, white flesh; for Summer use. Pkt. 5̌c., oz. 15c., 1/1 lb., 35 c., lb. $\$ 1.25$.

White Strasburg This is one of the best of the long Summer varieties; the skin Whe and flesh are pure white. Pkt. 5c., oz. 15c., 1/4 lb. 35c., lb. \$1.

Cincinnati Market. An extra-early variety of the Long Scarlet type; of a clear bright red color. Pkt. 5c., oz. 15c., $1 / 4$ lb. 35c., lb. $\$ 1.00$.

Chartier. Crisp and tender. Color is a scarlet or rose tipped with white at end. Roots are long and slender. Pkt. 5c., oz. $15 \mathrm{c} ., 1 / 4 \mathrm{lb}$. $35 \mathrm{c}$., lb. $\$ 1.00$.

Large White Summer Turnip Excellent for Summer use. Plt. 5c.,

\section{WINTER VARIETIES}

California Mammoth. Tery large white Winter variety. Pkt. 5c., oz, $15 \mathrm{c} ., 1 / \frac{1}{\mathrm{lb}}$. $35 \mathrm{c} ., \mathrm{lb} . \$ 1.25$.

Long Black Spanish. One of the hardiest and best for Winter use. Pkt. jc., oz. $15 \mathrm{c} ., 1 / 4 \mathrm{lb}$. 35c., lb. $\$ 1.25$.

Rose China Winter. Bright rose color, flesh firm. Plst. jc., oz. 15c., 1/4 lb. 35̌c., lb. $\$ 1.25$. 


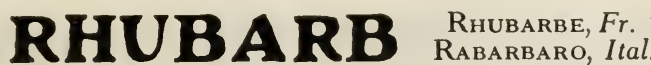

\author{
One ounce will produce 500 plants.
}

Culture-This plant is mostly propagated by division of the roots. The best time to set out the plants is early in the Spring, although it is sometimes done in Autumn. Make furrows of good depth, 3 to 4 feet apart, according to the variety planted; across these furrows, at right angles, make others the same distance apart; at each intersection put three or four shovelfuls of good manure, and upon this set the plants. Any good soil will suit Rhubarb; but to obtain heavy crops, good soil well manured is indispensable. A piece of root with a single bud, or eye, is enough for each hill. Cultivate during Summer. but do not pull any stalks the first year. Late in Autumn cover each plant with a good shovelful of manure, and plough a furrow against each side of the rows; this protection will assist the earliness of the crop. In early Spring level the ground, working in the manure with a fork. Plants can be obtained from seed, which may be sown in a hotbed in March, and the plants set out about the middle of May. It takes longer, however, to obtain a crop from seedling plant than from roots.

Victoria The earliest and best for garden use; not so coarse and fibrous 1 larger sorts. Pkt. 5c., oz. 20c., 1/4 lb. 50c., lb. $\$ 1.50$.

RHUBARB ROOTS. Doz. 75 c., $100 \$ 4.00$.

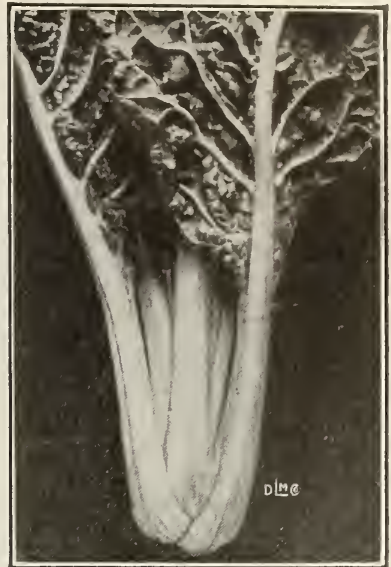

Swiss Chard

\section{SALSIFY, or OYSTER PLANT SAssFricic, Ital.}

One ounce will sow 50 feet of drill.

Culture.-It succeeds best in a light, well-enriched soil which should be

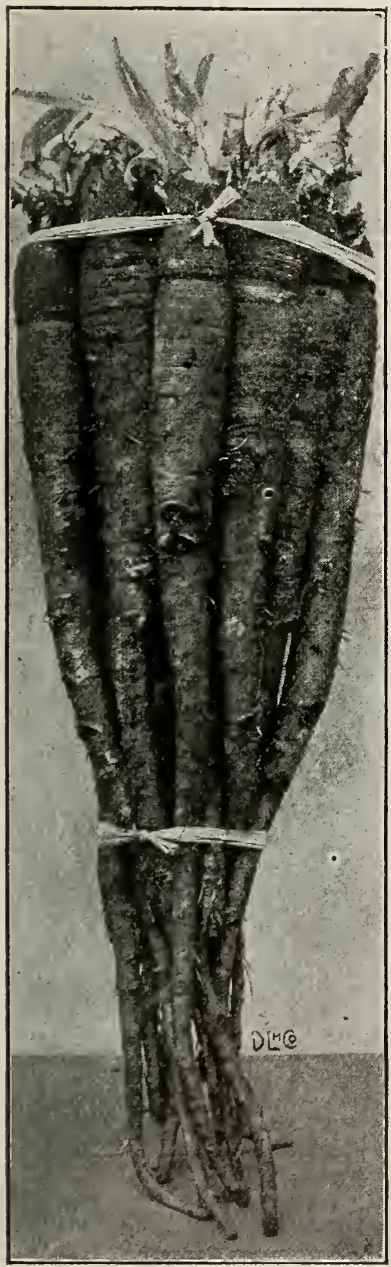

Mammoth Sandwich Island Salsify stirred to a good depth. Coarse and fresh manure should be avoided, as it will surely cause the roots to grow uneven and ill shaped. Sow early and quite deep, giving the general culture recommended for Parsnip. The roots are perfectly $h$ a r d y a n d may remain out all Winter, but 'should be dug early i n Spring, as they deteriorate rapidly after growth commences. Store a quantity for Winter use in a pit or in a cellar packed in damp earth or sand.
Mammoth

Sandwich

Island Market will find gardeners of the largest smoothest and most profitable in cultivation. The to $p$ remains in good condition until late the following Spring. Roots pure white in color and twice the size of $t \mathrm{~h}$ e ordinary Salsify. The long, wh it e, tapering root of S a ls if $\mathrm{y}$ when cooked forms a good substitute for oysters, having a very similar flavor. Pkt. 5c. and $10 \mathrm{c} ., 0 z .25 \mathrm{c}$. $1 / 4$ lb. $75 \mathrm{c}$., lb. $\$ 2.50$.
SWISS CHARD POREe, Fr. Giant Lucullus The leaves of Swiss Chard are same manner as Spinach, and the large ribs are prepared like Asparagus, in which manner they are delicious "Giant Lucullus" is the largest and best variety of the Swiss Chard. Pkt. 5c. and 10c., oz. $15 c ., 1 / 4$ lb. 35 c., lb. $\$ 1.00$.

\section{SORREL Oseille, $F r$.}

One ounce will sow 150 feet of drill.

Culture.- Sow seed in any good garden soil, in shallow drills a foot apart. Thin plants to a few inches apart and remove seed stalks as soon as they appear. Broad-leaved French Cooked like Spinach; a very fine salad cooked as greens. Large leaves, mild acid flavor, fine quality. Pkt. 5c., oz. 25c., $1 / 4$ lb. 75c., lb. $\$ 2.50$.

- 1 a C E - II a C S Spinaccio, Ital.

One ounce will sow 100 feet of drill; ten to twelve pounds will sow an acre.

Culture.-Spinach may be grown on any ordinary soil, and its cultivation is a very simple matter. It is grown both as a Spring and Summer crop. For early use, sow in August or September, in drills 12 to 14 inches apart. At the approach of cold weather cover lightly with straw, or any handy litter. Uncover when the plants begin to make a new growth in Spring. For Summer use, sow early in Spring in the same way as above, using rather less seed. If the plants stand too thick, thin to 3 or 4 inches apart. A liberal dressing of good manure should be used. The land can hardly be made too rich.

Savoy Leaf, Bloomsdale Very hardy,

popular. Productive, tender and excellent quality. Pkt. 5c., 0z. 10c. 1/4 lb. 15c., lb. 35c.

New Zealand unlike true Spinach in type and in that it thrives during hot soil rich or poor. The tender shoots are of good quality and may be cut throughout the summer. The plant becomes very large and spreading. The leaves are comparatively small, broad and pointed. Plant three or four seeds in hills two feet apart each way. Germination of the seed can be hastened by soaking in warm water twenty-four hours. Pkt. 5c., oz. $15 \mathrm{c} ., 1 / 4 \mathrm{lb}$. 35c. lb. $\$ 1.00$

Schultz's New Spring Produces large, thick, somewhat crumpled. I'kt. 5c., oz. 10c., $1 / 4$ lb. 20 c.,

Long Season Pkt. 5c., oz. 10c., 1/4 lb. 20c. Long Standing. Pkt. 5c., oz. 10c., 1/4 lb. 20c., lb. $60 \mathrm{c}$.

Victoria. Pkt. 5c, oz. 10c., 1/4 lb. 20c., lb. 60c. 


\section{SQUASH}

Courge, Fr.

Zucca, Ital.

One ounce Early will

plant 50 hills, one

ounce Marrow 25

hills.

Four to six pounds

for an acre.

Culture.-Squashes should be planted in a warm, rich soil, after the weather has become settled and warm about the middle of May or June. Plant in wellmanured hills, in the same manner as Cucumbers and Melons-the bush varieties 3 or 4 feet apart each way, and the running kinds 6 to 8 feet. Eight to ten seeds should be sown in each hill, thinning out after they have attained their rough leaves

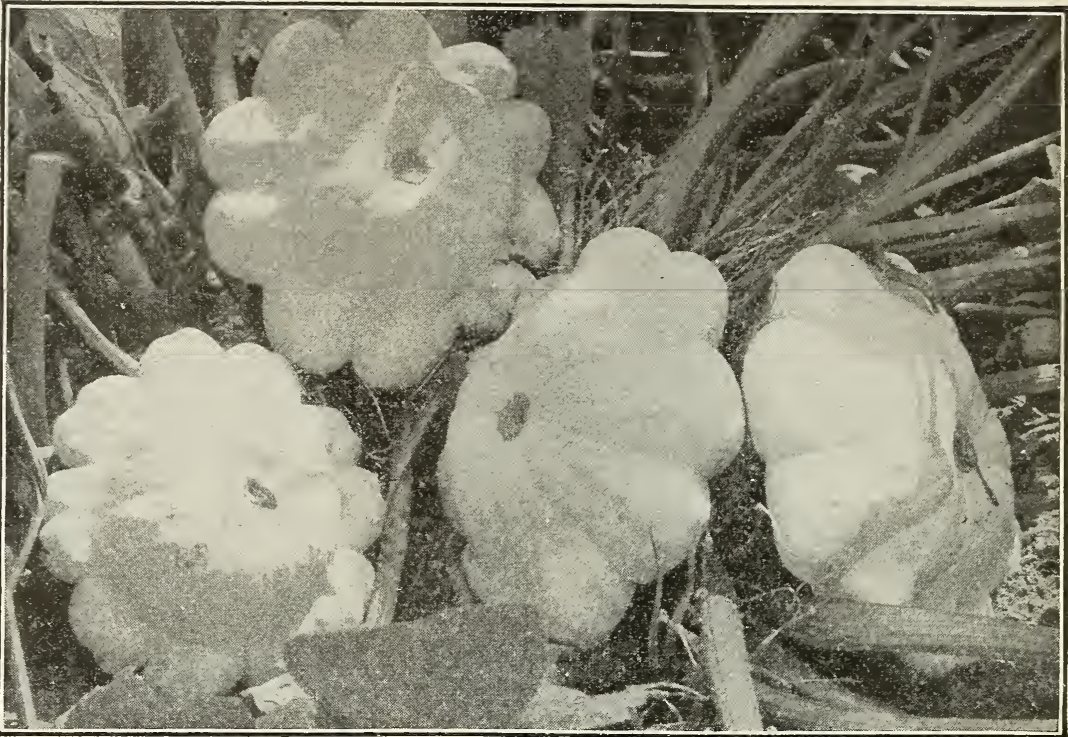

and danger from bugs is over, leaving three or four of the strongest plants per hill.

\section{SummerSquashes-ExtraEarly}

Schultz's Benning Bush The improvement Bush Squash over the old white sort is quite distinct, in that it is earlier and has a very beautiful light shade of green color, in place of the creamy white which the older sort has. The flesh is rich, dry, and particularly fine; medium in size; vine of bush habit, and exceedingly productive. Pkt. 5c. and 10c., oz. $15 \mathrm{c} ., 1 / 4 \mathrm{lb}$. $45 \mathrm{c}, \mathrm{lb} . \$ 1.50$.

Vegetable Marrow. This is the favorite English variety, bearing dull yellow, oblong fruits, 10 to 15 inches in length. The flesh is tender, marrowy, and delicious. The fruits should be used before fully grown. Pkt. 5c. and 10c., oz. 15c., $1 / 4$ lb. 50c., lb. $\$ 1.50$.

Burpee's Fordhook This is a most desirable summer and winter use. The vines are of strong, vigorous growth and wonderfully productive. Fruits oblong in form, eight to ten inches in length, slightly ridged; smooth, thin, yellowish skin; flesh very thick and of a light straw yellow. If gathered young for cooking, no other Squash approaches it in flavor. Pkt. 5c. and 10c., oz. $15 \mathrm{c} ., 1 / 4$ lb. $45 \mathrm{c}$., lb. $\$ 1.50$.

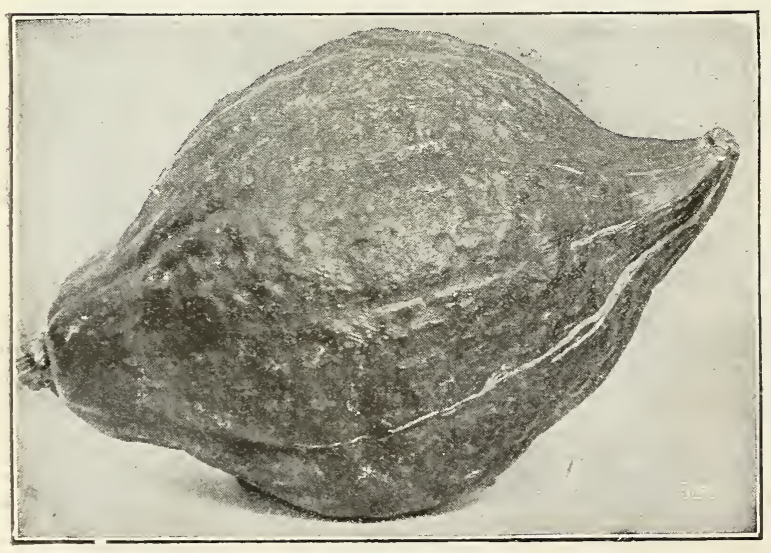

Yellow Summer Crook-Neck This old known variety still remains a favorite and is considered the best for Summer use. It is early, productive; good quality; skin orange yellow. Quality excellent. Pkt. $5 \mathrm{c}$. and 10c., oz. $15 \mathrm{c}$., $1 / 4$ lb. $40 \mathrm{c}$., lb. $\$ 1.25$.

\section{Fall and Winter Sorts}

Prolific, or Orange Marrow For a Fall Squash there is no Squash that can compare with this in earliness and productiveness, which are important features with the market gardener. Brilliant orange-red color, which makes it attractive in the market. Pkt. 5c., oz. 15 c., $1 / 4$ lb. 45 c., lb. $\$ 1.50$.

Boston Marrow. Color a rich orange, of good size, excellent flavor, and keeps well. Pkt. 5c., oz. 15c., $1 / 4$ lb. $45 \mathrm{c} ., \mathrm{lb} . \$ 1.50$.

Hubbard The most popular of all Winter varieties; an excellent keeper. Is of large size, often weighing from nine to twenty pounds. Color bluish green, occasionally marked with a brownish orange. Flesh is fine grain, dry and excellent flavor. Pkt. 5c., oz. $15 \mathrm{c}, 1,1 / 4$ lb. $50 \mathrm{c}$., lb. $\$ 1.50$.

Red, or Golden Hubbard a perfect type Hubbard, except in color, which is a bright, deep orange yellow, very showy and attractive. Its keeping qualities are fully equal to, while in productiveness it far excels, the Green variety. Pkt. 5c., oz. 15 c. $1 / 4$ lb. 35 c., lb. $\$ 1.25$.

Chicago Warted Hubbard This is the ideal Winter Squash for the home or market. The fruits are large, handsomely shaped, dark green, heavily warted skin, with rich flesh of splendid quality. Pkt. 5c., oz. $15 \mathrm{c} ., 1 / 4$ lb. $45 \mathrm{c} ., \mathrm{lb}$. $\$ 1.50$.

\section{TOBACCO}

Culture.-Sow in hotbed for early planting or sow in the open ground as soon as the ground is warm. Sow broadcast in rich, dry soil, pressing down firmly and cover lightly; water frequently. Set plants out first of June, 3 feet apart each way in land heavily manured.

Connecticut Seed Leaf. Saved from selected plants. Pkt. 10c., oz. 30c., $1 / 4$ lb. $\$ 1.00, \mathrm{lb}$. $\$ 3.00$.

Havana, Imported seed. Pkt. 10c., oz. 40c., $1 / 4$ lb. $\$ 1.25, \mathrm{lb}, \$ 4.00$ 


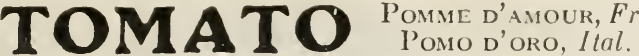

C.ne nunce will rroduce about 2,000 plants.

Culture.-For early plants sow in hotbeds early in March, in drills 5 inches apart and $1 / 2$ inch deep); when the plants are about 2 inches high, transplant into another hotbed 4 inches apart each way; plant out in the open ground early in May or as soon as danger from frost is over, 4 feet apart each way in hills, which should have a shovelful of well-rotted nanure mixed with the soil. Water freely at time of transplanting; when the first fruit is set, pinch off the ends of the branches to obtain early fruit. Sufficient plants for a small garden can be grown in a shallow box or large flower pot by placing it in a sunny window in a warm room or kitchen. For late use sow in a sheltered border in May and set out the plants in July; the green fruit can be picked off before frost and ripened under glass. By training the vines on trellises or tying to stakes, the fruit will ripen better and be of finer quality.

\section{Schultz's Early Splendid Is the} uable Early Purple Tomato in existence. An extra good all-around sort. We class it among the first to ripen its fruit. It has large size, is always smooth, of firm flesh, and is exceedingly productive. In color it is a fine glossy rose, tinged with purple. It stands alone with its distinct, delicious flavor, being mild and pleasant; unsurpassed for slicing. One other attractive feature of this Tomato is that it is almost immune from blight. Its blight-proof qualities are remarkable. Schultz's Early Splendid Tomato is splendid indeed. (See cut.) Pkt. 5c., and 10c., $1 / 2$ oz. 20 c., oz. 35c., $1 / 4$ lb. $\$ 1.15$, lb. $\$ 4.00$

Early Detroit The largest and smoothest early purplish pink Tomato. The vines are vicorous, blight-resisting, and very productive. The fruits are exceedingly smooth, uniform in size, firm and excellent quality. Early Detroit is?one of the most valuable shipping Tomatoes yet produced. It is also desirable for the home garden and near markets. Pkt. 5c. and 10c., oz. 35c., $1 / 4 \mathrm{lb}$. $\$ 1.15$, lb. $\$ 4.00$.

John Baer A fine extra early variety of a bright from core, with very few seeds and a mild sweet flavor, and ripening right up to the stem. Vines are vigorous and very productive. Pkt. 5c. and 10c., oz. $35 \mathrm{c} ., 1 / 4 \mathrm{lb} . \$ 1.15, \mathrm{lb} . \$ 4.00$.

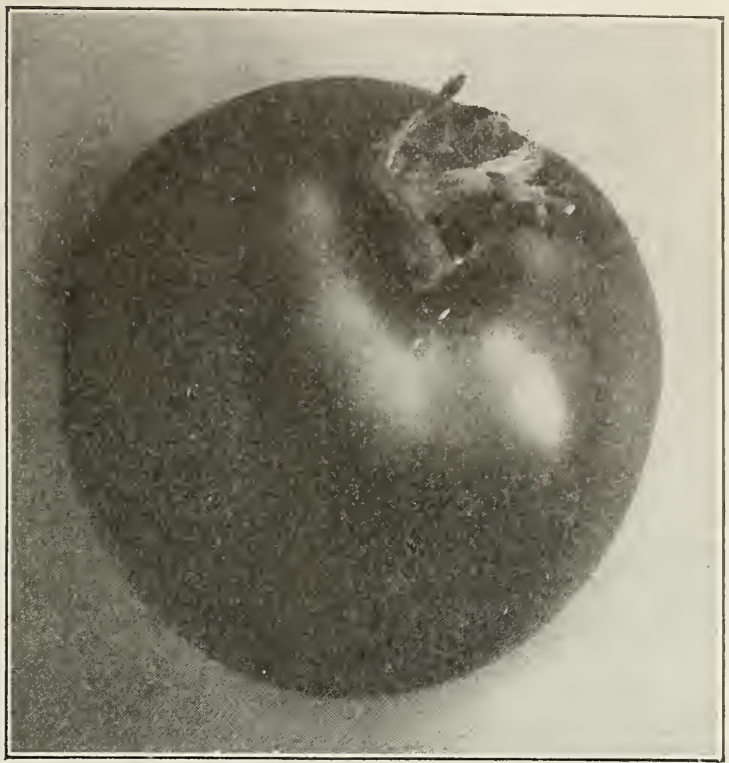

Early Splendid Tomato

Earliana Fine for extreme earliness as well as size, shape, color, and quality. Fruits y round, medium to large, bright and are borne in clusters. Pc. and $10 \mathrm{c}$., oz. $35 \mathrm{c}$., $1 / 4$ lb. $\$ 1.00$, lb. $\$ 3.00$.

"Bonny Best" Early It is a vigorous grower, wicn larger toliage than the Earlians a beautiful scarlet red; setting its fruit in clusters of five or more at close intervals. When ripening, each set ripens nearly all at once, and ripens evenly all over up to the stem. Pkt. 5c. and 10c., 1/2 oz. 20 c., oz. 35c., $1 / 4$ lb. $\$ 1.15$, lb. $\$ 3.50$.

Schultz's Faultless Introduced by us in chulz' A second-early variety. Color rich, soft pink, similar to our New Splendid, heavy cropper, round in shape, flesh very firm, large size, fine flavor. Ripens evenly to the stem, is a strong, healthy :grower, not subject to rust or blight, and produces until the vines are killed by frost, holding its size exceedingly well until the last picking. Pkt. 5c and $10 \mathrm{c}$, oz. $30 \mathrm{c}$. $1 / 4$ lb. $\$ 1.00$, lb. $\$ 3.50$.

Chalk's Early Jewel Valuable for deep scarlet-red, nearly round smooth, of large size and excellent quality. Pkt. $5 \mathrm{c}$. and 10c., oz. 35c., $1 / 4$ lb. $\$ 1.10$, lb. $\$ 3.50$.

Ponderosa The largest Tomato in Onistence. The vines are vigorous and tall growing, and extremely productive. The purplish pink fruits are very solid with few seeds, fairly smooth, and considered of very rood quality by those who prefer a Tomato quite free from acid. Pkt. 5c. and 10c., oz. 50c., $1 / 4$ lb. $\$ 1.50$, lb. $\$ 4.50$.

Livingston's Beauty One of popular kinds on our list; a favorite everywhere; early, large, round, smooth light purplish-pink tint; one of the best. Pkt. $5 \mathrm{c}$. and $10 \mathrm{c}$, oz. $25 \mathrm{c}$., $1 / 4 \mathrm{lb}$. $75 c ., 1 b . \$ 2.50$ 


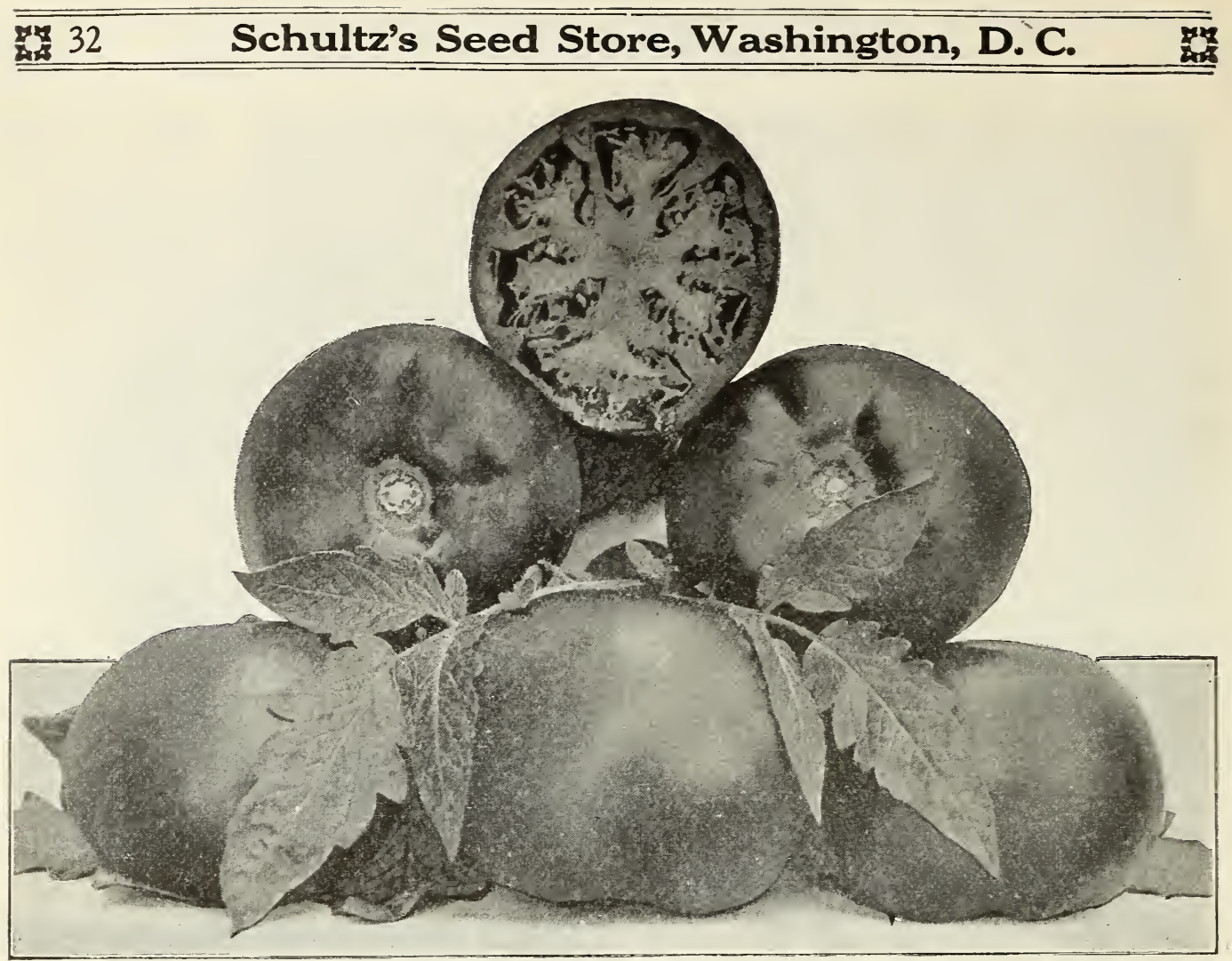

Schuitz's Selected Stone Tomato

TOMATO-Continued

Schultz's Admiration The largest fruited chultz's Admiration upright-growing variety in existence. In habit of vine it resembles Dwarf Champion, but is of stronger growth and more erect. In small gardens the plants may be set 18 to 24 inches apart each way, and yet produce an abundant crop. It is very solid, ripens evenly, with a good skin, which is free from cracks about the stem and the fruit resembles Livingston's Stone in its bright red color, shape and what is more remarkable, it is almost as large. Some idea of the large size of the fruits may be gained when we state that ten fruits have been picked from one vine at the same time showing a total weight of $5 \mathrm{lbs}$. and $3 \mathrm{ozs}$; single specimens weighing one pound are quite common. Pkt. 5c. and 10c., $1 / 2$ oz. 20c., oz. 35c., $1 / 4$ lb. $\$ 1.15$, lb. $\$ 4.00$.

Livingston's Globe. This new globe-shaped variety is very early, smooth and solid; skin a glossy pink; a heavy cropper, of excellent quality. Pkt. 5c. and 10c., oz. 35c., $1 / 4$ lb. $\$ 1.15$, lb. $\$ 4.00$.

Dwarf Champion. The foliage is very marked, of a dark green color; leaves thick and different from other sorts; fruits smooth, medium in size and similar in color to Acme. Pkt. 5c. and 10c., oz. 30c., $1 / 4 \mathrm{lb}$. $\$ 1.15$, lb. $\$ 4.00$

Selected Stone For a main crop this sort canete norpassed. It is one of the very best for canning or for market use. Fruit large, of bright red color, very smooth, heavy and solid. Pkt. 5c. and 10c., oz. $25 \mathrm{c}$., $1 / 4$ lb. $75 \mathrm{c}$., lb. $\$ 2.50$.

Success This is a very fine variety for late rop. The fruits are large, firm and solid. Color is a bright scarlet. A very attractive sort, either for the market or home garden. Pkt. 5c. and $10 \mathrm{c} ., 0 z .30 \mathrm{c} ., 1 / 4 \mathrm{lb}$. $75 \mathrm{c}$., lb. $\$ 2.50$.

Burpee's Matchless A large, bright red is Tomato. The fruit is smooth. The flesh is a rich, red color and of fine quality. Pkt. 5c. and 10c., oz. 30c., $1 / 4$ lb. $\$ 1.00, \mathrm{lb}$. $\$ 3.50$.
Red Rock This sort is well known and a favorRed Rock ite among canners. Pkt. jc. and 10c., oz. 25c., 1/4 lb. $75 \mathrm{c} ., 1 \mathrm{~b}$. $\$ 2.50$.

Greater Baltimore Is one of the best shaped, toes in existence. The fruit ripens evenly, is always smooth, free from cracks and holds its size to the end of the season. Flesh is of good flavor, very solid, with few seeds. Pkt. 5c. and 10c., oz. 30c., 1/4 lb. $\$ 1.00$, lb. $\$ 3.50$

Trucker's Favorite The smoothest and Trucker's Favorite best of the large sorts. Vines large, vigorous and heavy bearers; fruit large, uniform in size, very smootl, color of skin purplish pink. Pkt. 5c. and 10c., oz. 25c., 1/4 lb. 75c., lb. \$2.50.

Prizetaker. It is the size of Beautv, and matures with it. The color is a deep pink. Pkt. 5c. and 10c., oz. $25 \mathrm{c} ., 1 / 4$ lb. $75 \mathrm{c} .$, lb. $\$ 2.50$.

Improved Acme. One of the smoothest and most uniform, medium size, early, purple fruited sorts. Pkt. 5c., oz. 25c., 1/4 lb. 75 c., lb. \$2.50.

Early June Pink. In habit of growth it is similar to the Earliana. Fruits are pink. Medium size. Pkt. 5c. and 10c., oz. 35c., $1 / 4$ lb. $\$ 1.15$, lb. $\$ 4.00$.

Golden Queen (Queen of All the Yellows). Its superior flavor has brought it into general favor as a table fruit. It is solid, always smooth, entirely free from ridges, large in size, ripens early. Pkt. 5c. and 10c., oz. 35c., $1 / 4$ lb. $\$ 1.15$.

\section{SMALL FRUITED TOMATOES}

Largely used for making fancy pickles, preserves, etc.

Plum-shaped Yellow, Pear-shaped Red, Pearshaped Yellow, Red Cherry. Each at: Pkt. 5c. and $10 \mathrm{c} ., 1 / 2 \mathrm{oz} .25 \mathrm{c}$., oz. $40 \mathrm{c}$. 


High Quality Vegetable Seeds 33

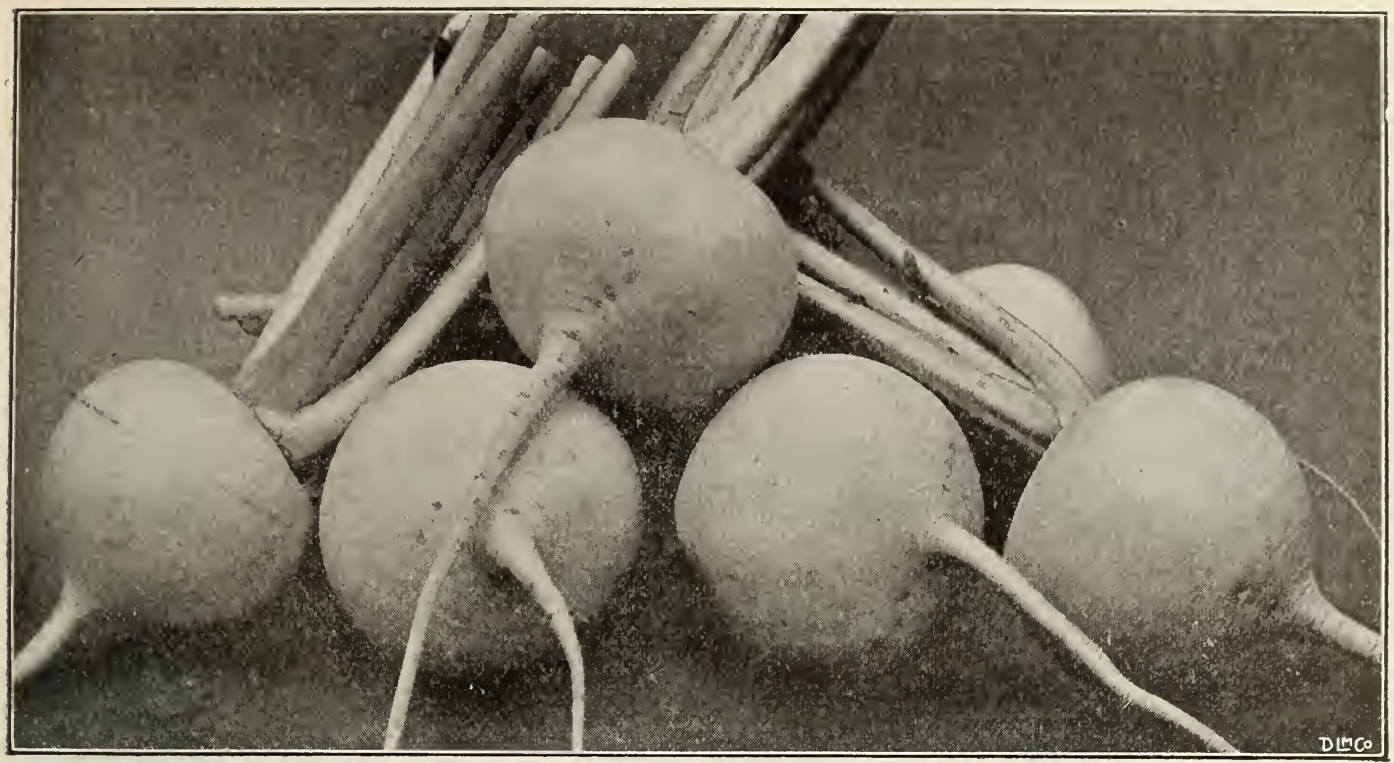

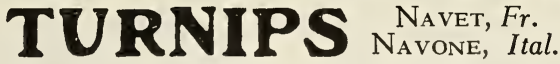

One ounce will sow 100 feet of row; one pound will sow an acre.

Culture.-The soil for Turnips should be rich and mellow. For early use sow as soon as ground opens in Spring in drills 12 to 18 inches apart and $1 / 2$ inch deep, or sow broadcast, although much larger crops are obtained by drill culture. When the plants are a few inches in height, and strong enough to resist the attacks of insects, thin them out to some 5 or 6 inches apart in the drills. For succession continue to sow every two weeks until June; for Fall and Winter crop sow from the first of July to September 10th.

\section{White Flesh Varieties}

\section{Purple Top White Globe $\begin{gathered}\text { This is the } \\ \text { most popular }\end{gathered}$}

Is of egg-shape and very rapid of all Turnips for market or home use. The shape is globular and of good size, and in appearance it is the best looking of all varieties, the white globe surface having an uneven purple edging at the top. The flesh is firm, fine grained, white and of most excellent flavor. It is a fine keeper, equally desirable for table or stock. An immense producer. Pkt. 5c. and $10 \mathrm{c} .$, oz. $15 \mathrm{c} ., 1 / 4 \mathrm{lb}$. 25c., lb. $75 \mathrm{c}$.

Extra Early Milan Purple top. This is the Trarliest Turnip grown. A flat, strapped leaf variety with white flesh. Skin white under ground; purplish red above. Two weeks earlier than other varieties. Pkt. 5c., oz. 15c., $1 / 4$ lh. $45 \mathrm{c}$., lb. $\$ 1.50$.

\section{Purple Top Strap Leaf, or Early Red Top}

Quick grower; flesh is very fine grain, sweet flavor white with purple top. More generally used than any other variety, both for market and for stock. Pkt. 5c. and 10c., oz. 15c., $1 / 4$ lb. 25c., lb. $75 \mathrm{c}$.

\section{Yellow Flesh Varieties}

\section{Large Yellow Globe The best yellow-} general crop, table or stock. Fine grained; color of skin yellow, top green. Grows to a large size is hardy, keeps well and is a good cropper. Pkt. 5c. and 10c., oz. 15c., 1/4 lb. 25c., lb. 75c.

\section{Golden Ball Medium-sized, globular form.} yellow, of season is early, flesh a golden Plt. 5c., oz. 15c., 1/4 lb. 25c., lb. $75 \mathrm{c}$.

\section{Yellow Aberdeen Large, glohe - shaped} lent for keeping. Good for both table and stock. Plt. 5c., oz. 15c., $1 / 4$ lb. 25c., lb. 75c.

Yellow Aberdeen, Purple Top. Bulbs globular form; deep yellow below ground, reddish purple above. Has a small tap root. Very solid and good quality. Pkt. $5 \mathrm{c} .$, oz. $15 \mathrm{c} ., 1 / 4$ lb. $25 \mathrm{c} ., \mathrm{lb} .75 \mathrm{c}$ firm, fine grain flesh. Grows good size. Excellent for early or late keeping in the Fall. Pkt. 5c., oz. $15 \mathrm{c} ., 1 / 4$ lb. $35 \mathrm{c}$., lb. $\$ 1.00$.

White Strap Leaf. Similar to the Purple Top Strap Leaf only in color, which is white. Pkt. 5c., oz. 15c., $1 / 4$ lb. $25 \mathrm{c} ., \mathrm{lb} .75 \mathrm{c}$.

Large White Globe. One of the most productive kinds. It is globe-shaped, skin white and smooth, leaves large and dark green. Pkt. 5c., oz. 15c:, $1 / 4$ lb. 25c., lb. $75 \mathrm{c}$.

Long White, or Cowhorn A quick-growshaped variety; flesh fine grained and sweet: an excellent sort for tahle use and stock feeding. Pkt. $5 \mathrm{c}$. and 10c., oz. 15c., $1 / 4$ lb. 35c., lb. $\$ 1.00$.

Southern Seven Top A variety much for the tops, which are used as greens only. Pkt. 5c., oz. $15 \mathrm{c} ., 1 / 4$ lb. $20 \mathrm{c}$., lb. $50 \mathrm{c}$.

Amber Globe A round, smooth, mediumAized light yellow Turnip, with crisp, firm flesh of fine quality. A good Winter sort. Pkt. 5c., $1 / 4$ lb. $25 \mathrm{c}$., lb. $75 \mathrm{c}$

\section{RUTABAGA}

\section{Swedish or Russian Turnips}

Culture.-The Swedish or Rutabaga varieties should be sown in drills 15 to 18 inches apart, at any time from June 1 to the middle of July, using about one pound of seed per acre. The plants should be thinned to about 6 or 8 inches apart

American Purple Top Improved. Marvorite. More largely grown than ket gardener's fa Yellow flesh, solid and fine quality. One of the very best keepers. Pkt. 5 c., 1/4 lb. $25 \mathrm{c}$., lb. $75 \mathrm{c}$.

Large White French, or Sweet German. A whitefleshed variety of large size and fine quality. Pkt. 5c., oz. 15c., $1 / 4$ lb. 50c., lb. $\$ 1.75$. 


Schultz's Seed Store, Washington, D. C.

\section{HERBS-Sweet, Pot and Medicinal}

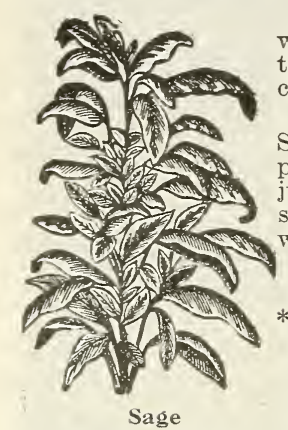

Castor Oil Bean.

bedding plants. Pkt. 5c., oz. $15 \mathrm{c}$.

*Catnip. For medicinal purposes, and relished by cats, who roll in it with great delight. Pkt. $10 \mathrm{c}$, oz. $35 \mathrm{c}$. Coriander. Seeds are aromatic. Pkt. 5c., oz. 15c. Dill. For Dill pickles. Pkt. 5c., oz. 15c., 1/4 lb. $40 \mathrm{c}$. *Fennel, Sweet. Used in sauce. Pkt. 5c., oz. 15c. *Horehound. Used for coughs. Pkt. 5c., oz. 25c. *Lavender. For perfuming linen. It is not hardy and should be covered during Winter. Pkt. 5c., oz. $35 \mathrm{c}$.

*Pennyroyal. Used medicinally. Pkt. 10c., oz. 60c.

*Peppermint. For flavoring. Pkt. (about 200 seeds), $25 \mathrm{c}$.

*Rosemary. Used for seasoning. Pkt. 10c., oz. 45c.

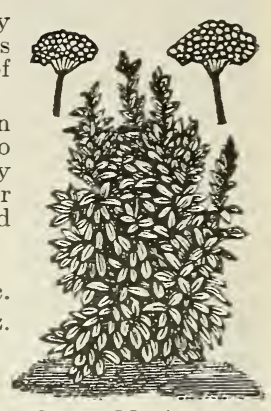

Sweet Marjoram

\section{VEGETABLE PLANTS and ROOTS}

We grow large quantities of Vegetable Plants and Roots, and can supply all the varieties listed below in their proper season.

If wanted by mail, add 15c. per 100 for postage on Cabbage, Cauliflower and Sweet Potato Plants, and 30c. per 100 on Egg Plants and Tomato Plants.

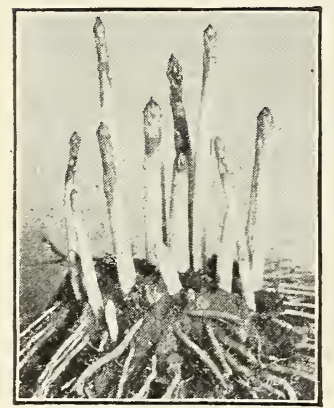

Asparagus Roots
Artichoke Plants, Selected Large Globe. Ready for shipment after March 1st. Doz. $\$ 1.50,100 \$ 10.00$.

Artichoke. Jerusalem Tubers. See page 6 .

Asparagus Roots

All varieties and prices at bottom of page 6 .

Brussels Sprouts. Doz $15 \mathrm{c} ., 100 \$ 1.00$.

\section{Cabbage Plants}

For April and May Delivery: Doz. 5c., 100 30c. Delivery June and July: per 100 25c., 1000 $\$ 2.50$.

Caulifower Plants. Snowball. From hotbed. Ready April and May. Doz. 25c., $100 \$ 1.00$.

Celery. Extra strong, transplanted plants. Delivery July. Doz. 15c., $10075 \mathrm{c} ., 1000 \$ 5.00$.

Chives. For flavoring. Clump 30c., 6 for $\$ 1.50$.

Egg Plants Ready in May and June. Trans-

Egg Plants planted. Doz. 50c., $100 \$ 3.50$.

Horse Radish Roots. Per $100 \$ 1.00$.

Lettuce. Ready in April and May. Doz. 10c., 100 $50 \mathrm{c}$.

Mint. Strong roots. Each 15c., doz. $\$ 1.50$.

Peppers Ready in May and June. Doz. 25c.,

\section{Rhubarb Roots Doz. 75c., 100, $\$ 4.00$.}

\section{Sweet Potato Plants Ready in May and} $\$ 2.00$.

Tarragon (Estragon). The young leaves are used for flavoring pickles, vinegar, etc. Each 30 c., doz. $\$ 3.00$
Tomato Plants Ready in April, May and of transplanted Tomato Plants, and can supply through the season of planting of the following varieties: Early Splendid, Ponderosa, Beauty, Stone, Admiration, Faultless, Bonny Best, Early Jewel and Prizetaker. Doz. from cold frames 30c. Pot grown 50c.

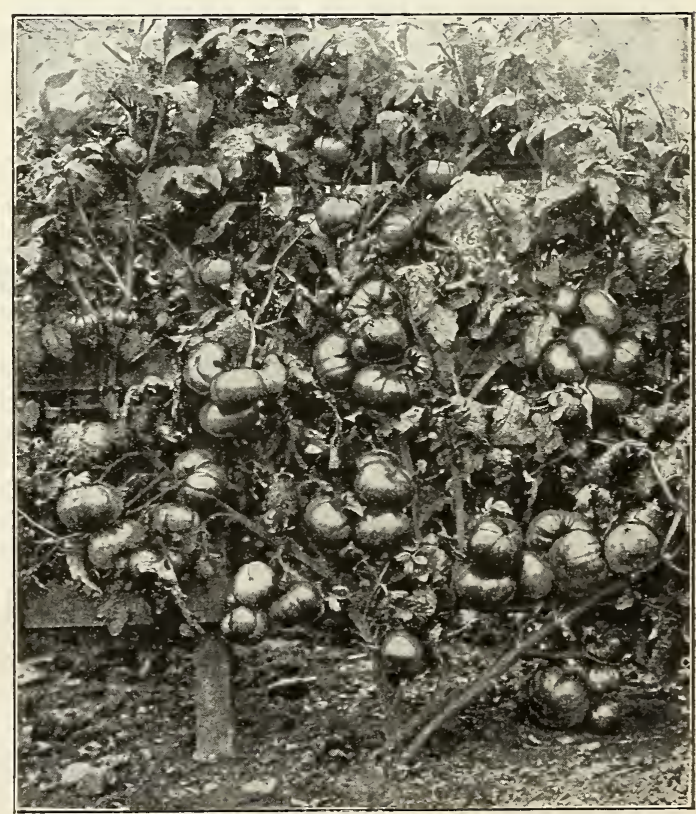




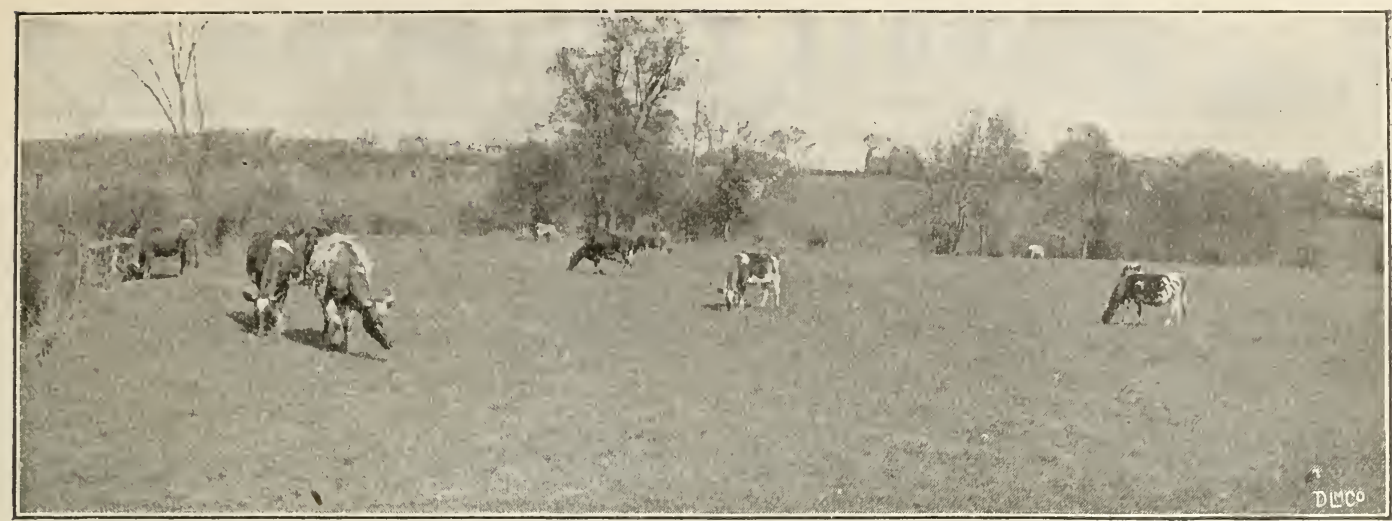

\section{GRASS SEEDS}

Prices subject to change without notice. Special quotations on large quantities.

We desire to call particular attention to the fact that Grass Seeds are sold in the trade by sample, and each sort is divided into three or four grades of quality, according to purity, germination and weight. The price of the best grade is often double that of the ordinary. The Grass Seeds here offered by us are in every case the very highest quality.

All Imported Grasses are hard to obtain, we quote prices subject only to being unsold.

CREEPING BENT (Agrostis Stolonifera). If sown alone use 35 lbs. to the acre. Lb. $75 \mathrm{c}$.

CREEPING, or RED FESCUE (Festuca rubra). Sow $30 \mathrm{lbs}$. to the acre. Lb. $40 \mathrm{c}$.

CRESTED DOG'S TAIL (Cynosurus cristatus) Sow $30 \mathrm{lbs}$. to the acre. L.b. $35 \mathrm{c}$.

ENGLISH RYE GRASS, or PERENNIAL RYE (Lolium perenne). Sow $60 \mathrm{lbs}$. to the acre. Lb. 20c.

FINE-LEAVED SHEEP'S FESCUE (Festuca ovina tenuifolia). Sow 35 lbs. to the acre. Lb. 50c.

HARD FESCUE (Festuca duriuscula). Sow $30 \mathrm{lbs}$. to the acre. Lb. $35 \mathrm{c}$.

ITALIAN RYE GRASS (Lolium Italicum). Sow 50 lbs. to the acre. Lb. $25 \mathrm{c}$.

KENTUCKY BLUE GRASS (Poa pratensis). For pasture sow about $28 \mathrm{lbs}$. to the acre; for lawns $3 \mathrm{lbs}$. per 1000 square feet. Lb. 35c.

MEADOW FOXTAIL (Alopecurus pratensis). Is never sown alone, but always in mixtures, using about 4 lbs. to the acre. Lb. $75 \mathrm{c}$.

MEADOW FESCUE (Festuca pratensis). Sow 35 lbs. to the acre. Lb. 30c.

ORCHARD GRASS (Dactylis glomerata). Sow 35

lbs. to the acre. Lb. 35c.

RED TOP FANCY, or RE-CLEANED (Agrostis vulgaris). If sown alone use $15 \mathrm{lbs}$. to the acre. $1 \mathrm{~b} .25 \mathrm{c}$. RHODE ISLAND BENT (Agrostis canina). For Lawns use $50 \mathrm{lbs}$. to the acre. Lb. $75 \mathrm{c}$.

ROUGH STALK MEADOW GRASS (Poa trivialis) Sow 20 lbs. to the acre. Lb. 40c.

SHEEP'S FESCUE (Festuca ovina). For pastures sow 35 lbs. to the acre. Lb. $35 \mathrm{c}$.

SUDAN GRASS. An annual. Resembles Millet somewhat; stock seem to relish it; will yield from 2 to 4 tons per acre. If seeded 18 to 20 inches 4 to $6 \mathrm{lbs}$.; if sown broadcast $15 \mathrm{lbs}$. Lb. 35c.

SWEET VERNAL (Anthoxanthum odoratum). Sow only in mixtures using 2 to 3 lbs. to the acre. Lh. $75 \mathrm{c}$.

TALL OAT GRASS (Avena elatior). Sow $50 \mathrm{lbs}$. to the acre. Lb. $35 \mathrm{c}$

TALL FESCUE (Festuca elatior). Use $40 \mathrm{lbs}$. to the acre. I,b. 35c.

TIMOTHY (Phleum pratense). Sow alone about 15 lbs. to the acre, when sown with Red clover, use 8 lbs. Timothy and 5 lbs. Red clover. Lb. 25c.

VARIOUS-LEAVED FESCUE (Festuca heterophylla). Sow $40 \mathrm{lbs}$. to the acre. Lb. $45 \mathrm{c}$.

WOOD MEADOW GRASS (Poa nemoralis). Sow about $30 \mathrm{lbs}$. to the acre. Lb. $75 \mathrm{c}$.

We make up Special Grass Mixtures for Meadows and Pastures. Will be glad to answer inquiries as to the best grasses for different purposes and for growing on various soils under varying climatic conditions.

\section{CLOVER SEEDS}

We quote present prices on Clovers as near as it is possible to offer them as we go to press. We shall be very glad to quote prevailing prices on all of them from time to time, and we solicit inquiries. It is understood, of course, that all are subject to market fluctuations.

ALFALFA, or LUCERNE (Medicago sativa). Requires deep, rich, well-drained soil. The tap-root descends often to a depth of 10 to 15 feet in loose soil. It is, consequently, capable of resisting great droughts. It should he sown alone (about same time as oats are sown in this section) in thoroughly prepared, deeply plowed soil, at the rate of 20 to 25 pounds to the acre. It mav also be sown, as late as August and up to the middle of September in more southerly localities. The crop should be cut - when the plant is coming into bloom. In suitable soil it is perennial, and se veral crops may be cut every year. Height, 1 to 3 feet. Lb. 25c., 15 lbs. $\$ 3.50$, bus. $\$ 12.50$.

ALSIKE, or HYBRID (Trifolium hybridum). A perennial, 1 to 3 feet high, succeeding best in cold, stiff soils and in marshy lands which are too wet for other species. It grows well, too, in high altitudes. A good honey plant for bees. $15 \mathrm{lbs}$. to the acre. Lb. 40 c., 15 lbs. $\$ 5.50$, bus. $\$ 20.00$.

BOKHARA CLOVER (Melilotus alba). Valuable sort for soiling and for ensilage and bees. Grows from 3 to 5 feet high; sown in rich soil may be cut three times; lasts for years if cut before flowering. $15 \mathrm{lbs}$. to the acre. Lb. 30c., 10 lbs. $\$ 2.50$.

CRIMSON, or SCARLET (Trifolium incarnatum) Erect annual, 1 to 2 feet high, with bright scarlet flowers. Largely grown in our Southern states for improving the soil by turning under. Sow 20 lbs. to the acre. Lb. 20 c., 15 lbs. $\$ 2.00$, bus. $\$ 6.00$.

MAMMOTH, or SAPLING (Trifolium pratense perenne). Grows nearly twice the size of the Common Red Clover. Sow about 8 to 12 lbs. per acre. Lb. 35c., 15 lbs. $\$ 4.00$, bus. $\$ 15.00$.

MEDIUM RED, or JUNE (Trifolium pratense). Sow in Spring or Fall and if no other Grasses are used, at the rate of 8 to 12 lbs. per acre. Lb. 35c., 15 lbs. $\$ 4.00$, bus. $\$ 15.00$.

WHITE CLOVER (Trifolium repens). It is of dwarf habit, spreads rapidly and is very hardy. It is valuable in permanent pastures, keing sweet and nutritious. Sow in Spring. In n ixtures, 1 or 2 lbs.; if alone, 8 or $10 \mathrm{lbs}$. to the acre. Lb. $75 \mathrm{c} ., 10 \mathrm{lbs}$. $\$ 7.00,100$ lbs. $\$ 65.00$. 


\section{GENERAL FARM SEEDS}

We will be glad to name prices on Farm Seeds upon application, inquiries cheerfully and promptly answered; samples mailed on request.

BARLEY, Beardless. Sow 2 to $21 / 2$ bus. per acre. Large heads of large grain; big yielder. Entirely free from beards. Bus. (48 lbs.)

BEANS, Soja (Mammoth Yellow). Sow $11 / 2$ bus. per acre broadcast, $1 / 2$ bus. in drills. Valuable as a forage crop and for silo purposes.

BUCKWHEAT, Japanese. Sow 1 bus. per acre. The best of all; early, large grain, enormous yielder. Bus. (48 lbs.).

CARROT, Improved Long Orange. Sow 4 lbs. per acre. Roots large and long; enormous yielder. Splendid for stock.

CORN, Kaffir. Sow 8 to 10 lbs. per acre. White. Excellent fodder plant; grain valuable for feeding poultry.

MILLET, Golden (Southern Grown). Sow 1 bus. per acre. Makes an enormous yield of nutritious food; succeeds in almost any soil. Sow in May or June.

OATS, White Spring. Sow 3 bus. per acre. Handsome and perfect White Oats; early and an erormous cropper. The straw is long, very strong and holds up well. The heads are large and well filled. Bus. (32 lbs.).

WINTER, or TURF OATS. For Fall sowing; hardy as far north as Pennsylvania. Bus. (32 lbs.)

PEAS, Field, for Fodder and Green Manuring. Sow 3 bus. per acre.

Canada White. Valuable for cattle feeding.

PEAS, COW, Black Eye. Sow 2 bus, per acre. After May 1st, for green Summer feeding and plowing under.

RAPE, Dwarf Essex. A forage plant of highest value. It can be sown in April for an early crop, and for Fall crop in July, August and September, it is sown broadcast $10 \mathrm{lbs}$. to the acre, but it is better drilled, in which case $5 \mathrm{lbs}$. to the acre will suffice. In a few weeks from the time of sowing, sheep, hogs or cattle can be turned upon it; all reports agree that they gain weight faster on this than any other fodder.
RYE, Winter. Sow $11 / 2$ bus. per acre. Very fine strain, grows 6 to $7 \mathrm{ft}$. high, giving 25 per cent. more straw than any other variety. Bus. (56 lbs.)

RYE, Rosen. Sow $11 / 2$ bus. per acre. This new Russian Rye is said to be the best variety now grown. The grain is large, plump and of light color.

SORGHUM, Or SUGAR CANE, Early Amber. Sow 8 to $10 \mathrm{lbs}$. per acre. Productive and nutritious forage plant, yielding several cuttings in a season. Earlier than Orange; may be grown in Northern States.

SUDAN GRASS. This recently introduced grass belongs to the Sorghum family, and, according to the reports of the United States Department of Agriculture is a very valuable grass for hay, especially in sections subject to drought, making good yields nearly everywhere. It grows 4 to $9 \mathrm{ft}$. high, according to cultivation, yielding two to five tons of excellent hay per acre, with as high as nine tons under irrigation. Should not be sown until the soil has become warm, about Corn-planting time or a little earlier. Sow broadcast at the rate of $25 \mathrm{lbs}$, to the acre.

SUNFLOWER, Mammoth Russian. Sow 4 lbs. per acre. Very productive, large heads of large seeds. Valued for feeding fowl.

VETCH, Hairy or Winter. This is one of the most valuable forage crops for the South, but requires to be sown in the Fall for best results. Can be sown any time from July to October. Succeeds admirably sown at the last working of Corn with Winter Oats or Wheat. Should be sown at the rate of 20 to 30 lbs. to the acre with one bushel of oats or $3 / 4$ bushel of Wheat. The Oats or Wheat help to hold the Vetch off the ground, enabling it to make a better growth. WHEAT, WINTER. (60 lbs. to the bus.) $11 / 2$ bus. to the acre.

Red Wave. Bald, red grain.

Klondyke. White grain; bald.

\section{Bird Seed, Etc.}

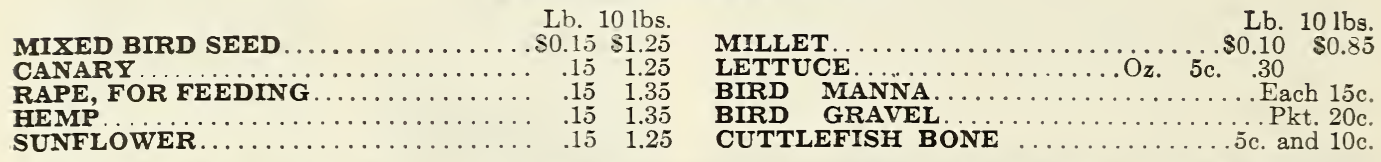

CUTTLEFISH BONE

\section{SEED INOCULATION}

White Clover Red Clover Crimson Clover

\section{Alsike Clover Alfalfa Clover Garden Beans}

\section{Mulford Cultures}

For inoculating all legume crops with nitrogen-fixing bacteria to increase the crop and improve the soil.

Five-acre size, \$5.00; 1-acre size $\$ 1.50 ; 1 / 4$-acre size, $75 \mathrm{c}$; small size, 35c. The small size only supplied in four varieties, for Garden Peas, Garden Beans, Lima Beans and Sweet Peas. Always specify on your order what crop you want to inoculate, a different variety being used for each legume.

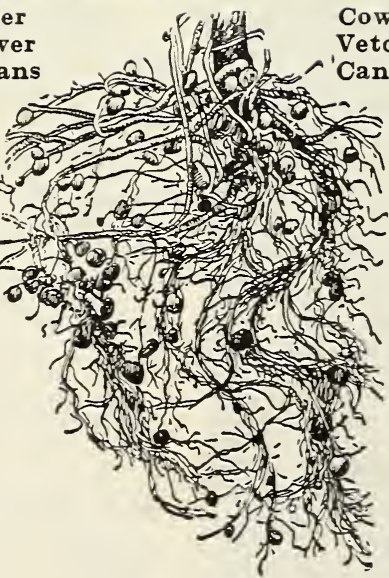

Soy Bean
Garden Peas Sweet Peas Soy Beans

\section{Farmogerm}

The original and genuine seed inoculant. A preparation of highbred, nitrogen-gathering bacteria in patent ventilated bottles, ready to use, with water added, according to directions.

Price per acre bottle, $\$ 2.00 ; 5$-acre bottle, \$8.00. When ordering state for what crop Farmogerm is wanted.

Also, in garden size, enough for 1000 square feet, or a $200-\mathrm{ft}$. row, at 50c. per bottle, for Peas, Beans, Sweet Peas and White Clover, each crop requiring a different bottle. 


\section{Schultz's High Grade Flower Seed}

Most flowering plants will live in almost any soil, but to give them a fair chance to develop, some care should be taken to make the ground suited to their needs. Many flowers are better if produced on plants of vigorous growth, hence a portion of the garden should be prepared by deep digging, thorough pulverization and liberal enriching with large quantities of well rotted manure. Since some other varieties produce the largest and finest colored flower's when grown on rather light, poor soil, a portion of the garden should not be enriched.

Cultural directions are given on the packets, and we urge purchasers to study them carefully. While some seeds need special treatment, the following general rules will apply to all. Make the surface of the soil as fine, smooth and level as possible; do not plant when the ground is wet; cover each lot of seeds to a uniform depth, which should not be more thai four or six times the diameter of the seed; press the soil firmly over the seed, plant in rows so that the starting plants can be seen easily; thin out the young plants to prevent crowding and keep entirely free from weeds.

Plants are usually divided into three classes, Annuals, Biennials and Perennials. Annuals are plants which normally live but a single season. Biennials are plants living two years; particularly those which do not bear flowers and fruit until the second season. Perennials tend to live from year to year.

\section{YOUR FLOWER GARDEN Whether your garden be small or large, start it right by se-} wasting his ground space by sowing seeds which have lain about 5 and $10 \mathrm{c}$. and Department stores for any length of time. Many of these places are ill fitted for seed storage; Seeds are resting, living plants, not pebbles. We have made a special study and business of growing Flower Seeds, and the stocks here offered are the best possible to produce.

Ageraturn One of the best bedding plants, being literally a sheet of bloom from early Summer till frost. Unlike many bedding plants, their flowers are not liable to be spoiled by rain, nor do the colors fade out. Half hardy annual.

Mexicanum Mixed. Blue and white. Pkt. 5c.

Alyssum, Sweet For borders, edging, rockdainty little eries and cutting, this dainty little flower has no superior in its color. For borders sow thickly; for Winter bloom sow in August and transplant to pots.

Little Gem, or Carpet-of-Snow. Plants only 3 to 4 inches high. A large mass of white, sweetscented flowers; fine for bordering. Hardy annual. Pkt. 5jc.

Amaranthus Brilliant foliaged annuals growing from 3 to 5 feet high, some of the varieties bearing curious racemes of flowers. All are useful in borders of tall plants or for the center of large beds. They thrive best in a hot, sunny location, not too rich soil, and given sufficient room to develop their full beauty.

Caudatus (Love Lies Bleeding). Blood-red, drooping. Pkt. 5c.

Tricolor (Joseph's Coat). Leaves red, yellow and green. Pkt. 5c., $1 / 4$ oz. 20c.

Asters One of the most popular and useful of all may be sown in the house or greenhouse in March or April, and transplanted in the open ground in May. However, as the Aster is a Fall flower, and the late blossoms are the finest, it is best to sow the seed in the bed thinly early in May and transplant. Half hardy annuals.

Giant Branching. A class of Asters useful for cut flowers. They are very large and double, borne on long, stiff stems, and the colors are clear and handsorne. A favorite with florists.

Flesh Pink. Pkt. 10c. Purple. Pkt. 10c.

Lavender. Pkt. 10c. White. Pkt. 10c.

Dark Red. Pkt. 10c.

Finest Mixed. A mixture of very fine strains and colors. Pkt. 5c.

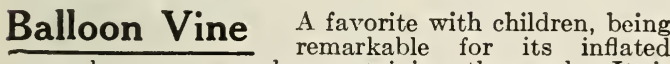
membranous capsules containing the seed. It is sometimes called "Love-in-a-Puff." A rapid and graceful climber. Flowers small, white. Tender annual. 6 feet high. Pkt. $5 \mathrm{c}$.

Balsam Known as Lady Slipper and Touch-MeRose-like flowers of this well-known colored, double, bedding annual are thickly set along the branches of the erect, bushy plants. The colors range from white to dark purple. Hardy annual. 18 inches high. Pkt. 5c.

Calendula (Pot Marigold). A most popular kind of soil, makes a fine effect in my, grows in any ders, a good potting flower.

Large Double, Finest Mixed. Pkt. 5c.

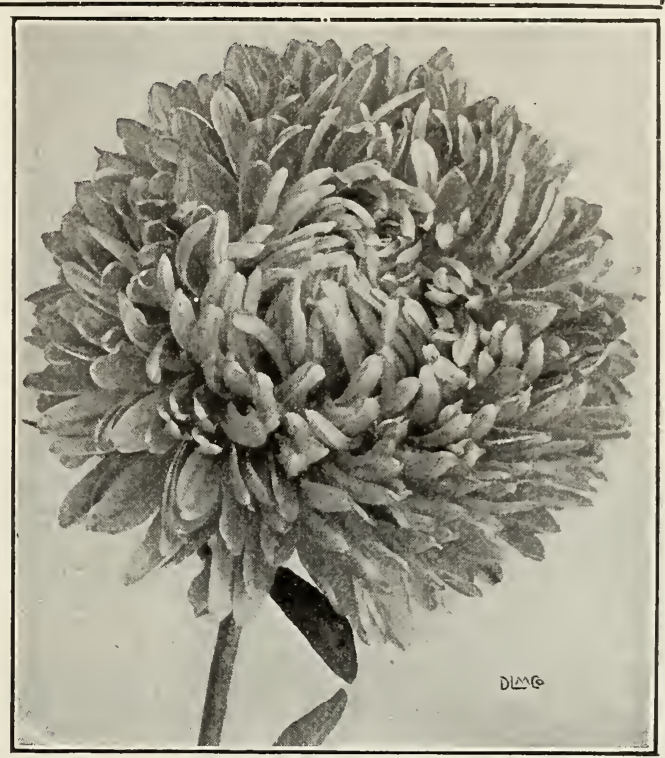

Giant Branching Aster

Calliopsis Showy and beautiful free-flowering well in any sunny position, blooming all Summer and excellent for cutting and massing.

Golden Wave (Drummondii). Rich golden-yellow with small, chestnut-brown center; very free; 12 inches. Pkt. 5c.

Canary Bird Vine A rapid growing Sumly cut foliage and yellow flowers. Tender annual. Pkt. $5 c$.

Candytuft Showy, hranching plants, 6 to 18 ting and very effective in beds or masses. If sown in Spring will bloom from July to September, or in the Fall will blossom from May to July. Hardy annual.

Fine mixed. Pkt. 5c. Popular and beautiful Canterbury Bells Popular and beautifu great profusion of attractive, bell-shaped flowers. Single Mixed. Pkt. 5c. Carnation of the most esteemed of the florists' collection. Sow under glass in greenhouse or hotbed, and when of sufficient size transplant 1 foot apart each way. Half hardy perennial. $11 / 2$ feet.

Giant Marguerite. With ordinary care will be in full bloom in 4 months after sowing the seed, flowering in profusion until checked by frost. The flowers range through many shades. Pkt. 10c. 
Cardinal Climber One of the best annual many years. Rapid grower, with branching habit; flowers all Summer in fiery cardinal-red clusters; 25 feet. Pkt. 10c.

\section{Castor Bean}

or RICINUS. Tall, majestic plants for lawns, with leaves of glossy green, brown or bronzed metallic hue and long spikes of scarlet, or of green, prickly fruit. Of very quick growth in rich soil. Tender annual. 6 to 15 feet high. Pkt. 5c.

Celosia or CoxсомB. Free blooming, graceful Clants, growing best in rather light soil, not too rich; grown in pots they are fine for the greenhouse or conservatory. Half hardy annuals. Pkt. 10c.

$\underline{\text { Centaurea Cyanus (Bachelor's }} \begin{gathered}\text { Button, } \\ \text { Corn Flower). A well- }\end{gathered}$ known, hardy border plant, also called "Blue Bottle," "Ragged Robin" and "Ragged Sailor," which does best in carefully prepared gravelly soil. It flowers from July until late in the Autumn. Hardy annual. Plant 1 to 2 feet high. Mixed. Pkt. 5c.

Chrysanthemums The annual Chrysanthethe mums are distinct from mer and making a gorgeous display in the flower garden and for pot culture. Double Mixed 5c. Annuals.

Clarkia Beautiful hardy annuals with rose-colored brilliant shades. The plants are about 18 inches high and profuse bloomers. Mixed, double. Pkt. 10c.

Cobra (Cups and Saucers Vine). A climber of Cobaea rapid growth, attaining a height of 30 to 50 feet during the season; valuable for covering trellises, arbors, trunks of trees, etc.; will cling to any rou'gh surface. In sowing, place seeds edgewise and merely cover with light soil.

Scandens. Large, bell-shaped purple flowers. Pkt. $10 \mathrm{c}$.

Columbine (Aquilegia). Every well regulated hardy perennials, and no bed of perennials would be complete without a due proportion of Columbines. They are of the easiest culture and when once established will furnish for many years a magnificent display of the handsomest flowers each Spring and Summer.

Mixed. Pkt. 10c.

Coreopsis Lanceolata grandiflora. This is one Coreopsis of the finest of hardy plants, with large, showy bright yellow flowers, produced in the greatest abundance from June till frost. As a cut flower they stand near the head among hardy plants, having long stems and lasting in good condition a week or more. Easily grown from seed, flowering the first year if sown early. Pkt. 10c.

Cosmos Very effective for Autumn flowering in and rapid growing annual, forming bush-like plants with feathery green foliage, 4 to 6 feet high, covered with large flowers somewhat resembling the single Dahlia. They are gracefully poised on long stems and are very useful for decorative purposes.

New Double Flowering. This novelty varies considerably in its degree of doubleness, some of the flowers being perfect, while others have a crested center, with the outside petals forming a collar, each type being very showy. This variety can readily be told when quite young, owing to foliage being heavier than the single variety. Pkt. $15 \mathrm{c} ., 1 / 4$ oz. $50 \mathrm{c}$.

Early Flowering. This strain blooms in August. It is a strong, vigorous grower with lovely flowers of white, pink and crimson. Pkt., Mixed, $5 c$.

Giant Fancy. These giant flowers are exceedingly beautiful. It is well to start the seeds of this class in the house early and transplant to open ground after hard frosts are past. Giant Pink, pkt. 10c.; Giant White, pkt. 10c.; Giant Red, pkt. 10c., Giant Crimson, pkt. 10c.; Giant Mixed, pkt. 10c.

Cypress Vine A most beautiful climber with foliage and an delicate, dark green, feathery scarlet or white blossoms. Tender annual. About 15 feet high. Mixed, pkt. 5c.

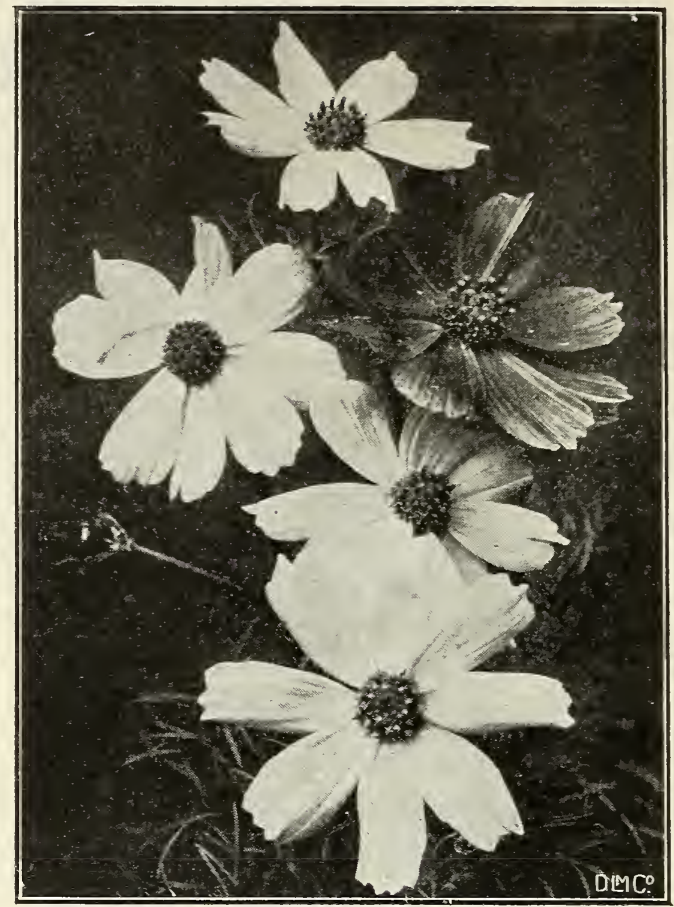

Giant Fancy Cosmos

Double Daisy (Bellis). A favorite perennial, given the protection of a little litter. In bloom from early Spring until well on in the Summer. Easily raised from seed, which may be sown any time from Spring till August. Finest double-flowering. Pkt. $10 \mathrm{c}$.

Dahlias One of the best late Summer and Autumn ahlias flowering plants, and now enjoying a wide popularity; the double sorts will bloom the first season if the seed is sown before the beginning of April.

Double Mixed. Pkt. 10c.

Eschscholtzia (California Poppy). A bed in full bloom of these large, fowers in various shades of yellow with orange center, gives a brilliant color effect. The foliage is finely cut and has a bluish tinge or bloom, delicate and very attractive. Hardy annual. About 18 inches high. Pkt. 5c.

Forget-Me-Not (Myosotis). A favorite oldprofusion, especially in Fall and Spring, clusters of dainty blue, five-petaled blossoms. It thrives well in the shade or open border but flourishes best in a moist, shady, situation. Hardy perennial. About 8 inches high. Pkt. 5c.

Four o'Clock (Marvel of Peru). A wellering garden favorite; does well everywhere; give each plant 12 to 18 inches of room. Fine mixed, $5 \mathrm{c}$ Foxglove (Digitalis). Grows to the height of 3 oxglove or 4 feet, affording dense spikes of brilliantly colored flowers. Colors white, lavender and rose. A valuable flower in every perennial garden. Hardy biennials or perennials. Pkt. $10 \mathrm{c}$. Gaillardia (Blanket Flower). Splendid showy size and brilliancy of their flowers, continuing in bloom from early Summer till November; excellent for beds, borders, or for cutting; should be sown where they are to bloom; $11 / 2$ feet. Mixed, pkt. 5c

Geranium Zonale, Mixed. A superb strain Geranium of the largest and finest varieties. started indoors and transferred to the open in I fay or June. Mixed, pkt. 10c. 
Godetia Attractive, hardy annuals, deserving more extensive cultivation. The plants bloom profusely, and bear showy flowers of satiny texture in many rich and varied colors. They do best in a rather poor soil; 1 foot.

\section{Dwarf Mixed. Pkt. 5c.}

Gomphrena ((ilobe Amaranth). Popularly heads and can be dried and used in Winter bouquets. C'ornflowers and a number of other flowers are also known as Bachelor's Buttons.

Mixed. Pkt. 5c.

Gourds (Cucurbita). A tribe of climbers with curiously shaped and colored fruit. Being of rapid growth they are fine to cover old fences, trellises, stumps, etc. Tender annual. 10 to 20 feet high.

Mixed. Pkt. 5c., oz. 20c.

Gypsophila (Baby's Breath). Pretty free-flowin any cring elegant plants, succeeding bloon are largely used for mixing with other cut flowers. Pkt. $5 \mathrm{c}$.

Helichrysum (Straw Flower). A hardy anour best. "Everlasting" fhe easiest culture; one of blooms being very handsone in Winter bouquets; 2 feet.

Finest Mixed. Pkt. 5c.

Heliotrope A universal favorite on account of of bloom. Seed sown in the Spring makes fine plants for bedding out, and are as easily grown as Verhenas. The colors of the blossoms range from white through all shades of violet to the deepest purple.

Mammoth Mixed. Pkt. 10c.

Hibiscus (Marshmallow). Showy, ornamental perennial plants for mixed beds or shrubbery borders, having large-sized beautifully colored flowers. Pkt. 10c.

Helianthus (Sunflower), The strong growth of these well-known plants makes them unsuitable for bedding; but they are very useful for massing in shrubbery or borders, and for screening purposes. They do well in sunny positions, in any kind of soil. The dwarfer kinds, with smaller flowers, are charming when grouped in mixed flower borders. Excellent for cutting.

Chrysanthemum-flowered. Extra large, double yellow flowers, 6 to 10 inches in diameter. 5 feet. Pkt. 5c.

Large Russian. A very tall growing single variety. 10 to 15 feet. Pkt. $5 \mathrm{c}$

Hollyhock One of the most majestic of hardy plants, and Holly a clump or line in any garden gives an effect not attainable with any other plant. For planting among shrubbery or forming a background for other flowers, it is without equal. Seed sown any time before mid-Summer will produce fine plants for flowering next year. Finest Double Mixed. Pkt. 10c.

Humulus (Japanese Hop). Japonicus. A very ornamental sembles in and fast-growing climbing plant. The foliage rein color a lively green; annual. Pkt. 10c.

Hyacinth Bean (Dolichos Lablab). A fine climber with clusters of purple or white flowers followed by ornamental seed pods. Tender annual. 10 to 15 feet high. Pkt. 5c.

Job's Tears Curious ornamental grass with broad, corn-like leaves and lustrous slate-colored seeds, used for beads Valuable for Winter bouquets with everlasting flowers. Plant outdoors early in Spring in hills 3 feet apart, 4 or 5 seeds in a hill, and cover half an inch deep. Hardy annual. 3 feet high. Pkt. 5c.

Kochia (Summer Cypress, or Mexican Fire Bush). An easily grown annual, which, sown thinly in Spring, soon forms a cypress-like hedge of the most lively green and of perfect symmetry; by mid-Summer it attains a height of about 3 feet, and on the approach of Autumn the whole plant becomes a deep red. Pkt. 5c.

Lantana One of the most desirable half-hardy perennial Verbena-like greenhouse or bedding plants; constantly in bloom: of onge, white, rose and other colored flowers; 2 to 3 feet. Mixed colors. Pkt. 10c.

Larkspur The Larkspur with its long clustered spikes of beautiful irregular flowers, often with long spurs, is especially valuable for its shades of hlue. The annual forms are very valuable for bedding. Tall Double Mixed. Pkt. $5 \mathrm{c}$.
(Everlasting, or Hardy Sweet Pea).
Showy, free-flowering hardy perennial cering old stumps, fences, etc. con-

Charming plants, well adapted for
Chent fine for cutting. Plt. 5c. bedding, pots or rockeries. It makes a edging for beds of white flowers and is very we in masses, being completely covered with lue with light center. Half liardy annual.

ove-in-the-Mist This singular plant is also reen and as Devil-in-a-Bush, because the blooms artly concealed by the abundance of finely cut iage. The plant and flower are each handsome and ed. Pkt. 5c.

pin Very conspicuous plants with spikes of ooks well as a background to other lower growing nnuals. Hardy annual; about 3 feet high.

Sold are old favorite free-flowering angolds f easy culture; both are extremely effective. The rmer have uniformly large yellow or orange-colored ers, and are well adapted for large beds or mixed fully striped flowers, and better suited for bedding urposes, or for pot culture; they succeed best in a soil, with full exposure to the sun.

gnonette (Reseda Odorata). Seed of this popular hardy annual can be sown any time, and if successive sowings are made, its utdoors until November. Sow in pots or boxes der glass in February or March, and thin or pot ff the seedlings to make good plants for bedding in May.

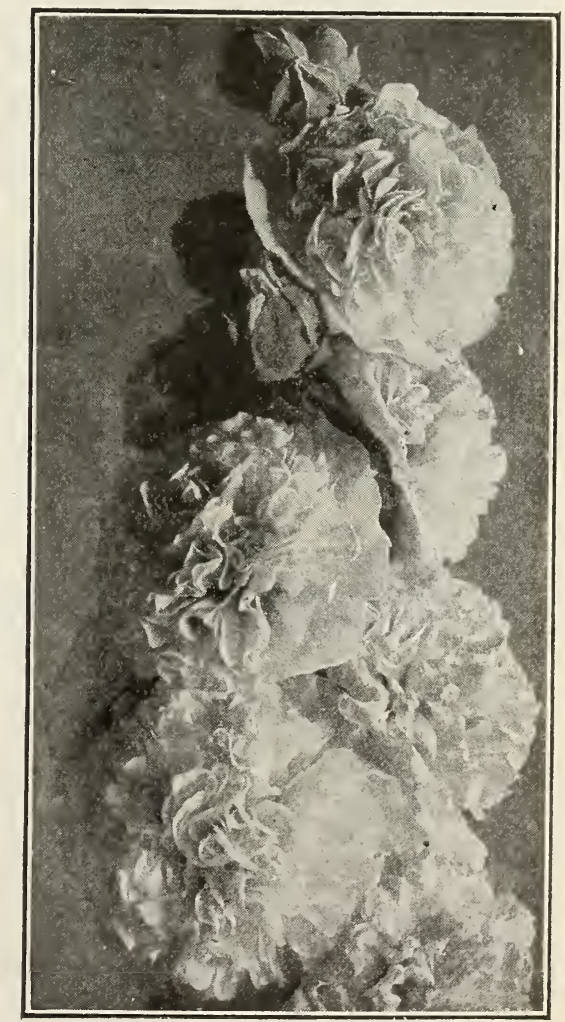

Double Hollyhocks 


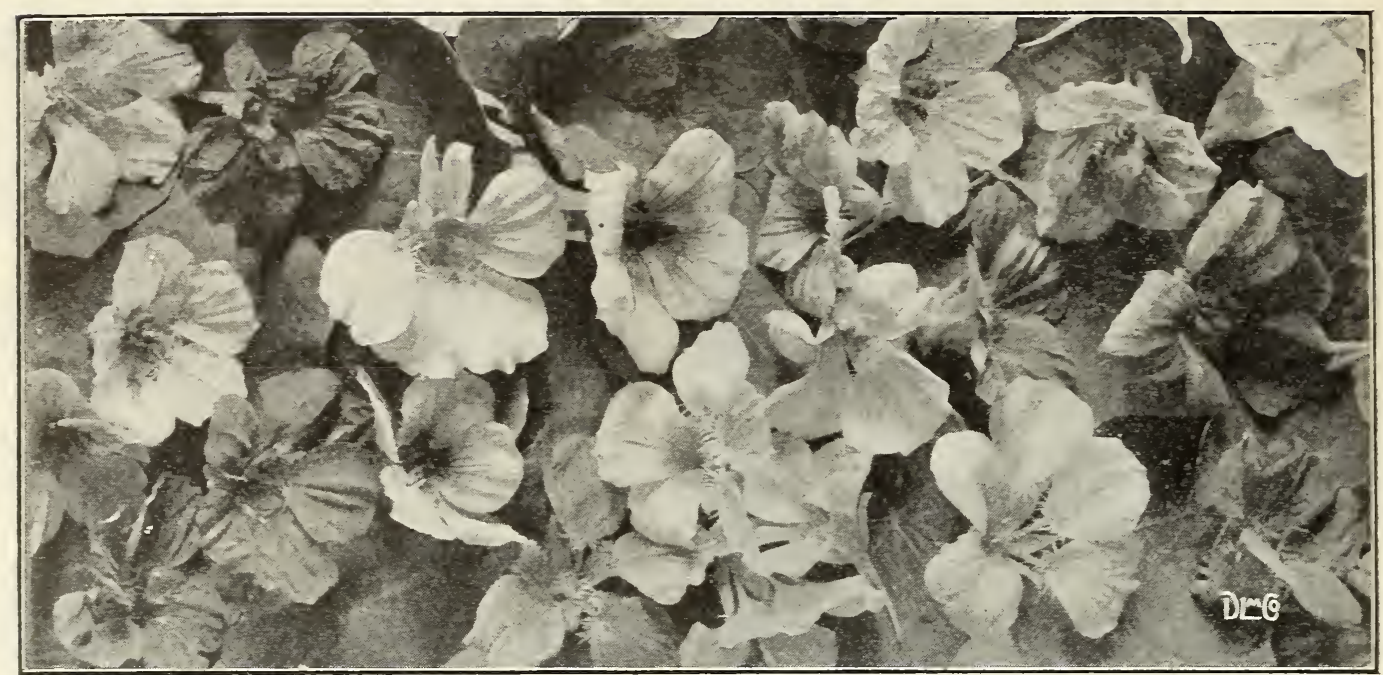

Nasturtiums

Mormordica Gracefully climbing rines with fruits of curious shape teellow blossoms, followed by run 10 feet or more during the season. The seed is very hard and germination will be hastened if a notch is carefully cut through the shell before planting.

Balsam Pear (Charantia). The fruit is pear-shaped, green, changing to bright red, and has a warty skin; when ripe it bursts open and shows a brilliant interior of large carmine seeds. Pkt. 5c.

Balsam Apple (Balsamina). Like Balsam Pear, but foliage smaller: fruit much smaller and nearly round, green striped when young, becoming scarlet. Plkt. 5c.

Moon Flower (Ipomca grandiflora alba). mer climbers and will grow under farorable conditions 30 to 40 feet in a single season and be corered erenings and cloudy days with rery large, white, trumpet-shaped flowers widely extended, often 1 inches across. Leaves large, 5 inches across. The hard outer coat of the very large, light rellow seed should be cut through with a sharp knife, care being taken not to cut any deeper than the hard shell. Tender annual. Pkt. 10c., oz. 50c.

Morning Glories Japanese Giant. A class of 20 to 30 feet quite early in the season. Their large flowers are striped, spotted and margined in all shades from white to the deepest red. blue and purple. Many are fluted and fringed. Sow the seeds early in a warm. sunny place. Choice mixed. Pkt. 5c.

Morning Glory (Convolvulus major). The wellknown, old-fashioned Morning Glories. Splendid climbing plants. Of rapid growth and profuse bloom. Pht. 5̃c.

\section{Nasturtium}

Fer plants are more easily grown or remain longer in bloom than the Tropæolum. with its large, shield-shaped leaves and beautifully irregular flowers haring long spurs and brilliantly colored petals. Seed is usually sown outdoors as soon as the weather is warm and settled, in the row where the plants are to remain. A sunny situation is essential for free blooming. If the soil is very rich the plants give a large amount of foliage but few flowers.

Schultz's Rainbow Drarf Mixed. The flowers are rery brilliant and attractive. Plants evenly dwar and are often used for a border. When about 2 inches high thin so as to give each plant about 1 foot of room. Hardy annual. About 1 foot high. Pkt. 5c., 0z. $15 \mathrm{c}, 1 / 1 \mathrm{lb}, 50 \mathrm{c}$. 1b. $\$ 1.50$.

Schultz's Tall, or Trailing Mixed. Elegant and luxuriant climbers for verandas, trellises, etc. May be used to cover unsightly railings and to trail over Iough ground with fine effect. The seed pods can be gathered while green and tender for pickling: 6 to 10 feet. Plt. $5 \mathrm{c}$., oz. $15 \mathrm{c}$., $1 / 4 \mathrm{lb}$. 50c., lb. \$1.50.
Pansy Pansies delight in a cool, moist soil and a winds situation that protects them from cutting flowersearly in Spring, seed should be somn in July or August and the plants protected with a frame during Winter. Spring-sown seed do very well, although the flowers produced are not so large.

Giant Trimardeau. Tery large flowering; all colors mixed. Plt. 10c., 1/4 oz. 75c., oz. \$2.50.

Petunias Petunias are one of the most popular annuals on account of their ease of cultiration and freedom of blooming. succeeding everywhere and giving a constant supply of flowers from June to October. They are also good house plants, flowering freely in a sunny window. Seed can be sown in the open ground early in the spring or in a hotbed or coldframe, to be transplanted later to beds or borders. Height, 1 to $11 / 2$ feet.

Finest Single Mixed. Pkt. $10 \mathrm{c} ., 1 / 1$ oz. $45 \mathrm{c}$., oz. \$1.25. Phlox Drummondii Phlox makes a magand masses where their brilliant and raried colors produce a gorgeous efiect. Tery easily raised and afford a bright display of flowers all through the Summer. Sow seed in the open ground in the Spring. A light soil is best.

Choicest Mired. Plit. 10c.

Pinks (Dianthus). There are fer annual flowers color for so long a time as the various varieties of Dianthus. Seed sown in the Spring produce a beautiful display in flowers from July to November. If the plants are given some light protection ther will live over Winter and flower very early the following Spring.

Double Japan Pink (Dianthus Heddewigii). Remarkably large and double, and of brilliant colors. The flowers are as large as the finest Carnations. Mixed colors. Pht. 5c., 1/4 oz. 25c.

Double Chinese Pink (D. chinensis). Flowers very double and produced in clusters. Pkt. 5c., 1/4 oz. 25c. Single Dianthus. The single-flowering Dianthus makes a most brilliant show of color in the garden. Pkt. 5c., 1/4 oz. 25c.

Poppies Annual and perennial plants of very easy culture. which furnish some of the most brilliant colors in the garden. Being vers hardy; they can be sown as early in the Spring as the ground is in working order and the annual varieties will flower from June on for some weeks.

Shirley. The rery finest strain of single Poppies. All colors from white to deep scarlet. Pht. jc., 1/4 oz. 15c., oz. 30c.

Portulaca There is scarcely any flower in cultidisplay of beauty as a bed of brilliant colored Portulacas. They thrive best in a rather rich, light loam or sandy soil, and an exposed sunny situation. Half-hardy annual. Single Mixed. All colors. Plt. Jैc. 
Salvia Splendens (Scarlet Sage). Very ornaalvia mental plants, for Summer and Autumn flowering; bloom in spikes, and continuing to blonm in the open ground until hard frost, forming compact bushes, which are literally ablaze with brilliant flowers. While tender perennials they bloom like annuals the first season from seed. The plants may be started in a box in the house, or in the hotbed, and when the weather becomes warm transplant in the garden. May be used as a hedge with striking effect,

Splendens Grandiflora (Scarlet Sage). Gorgeous plants, numerous spikes of intensely vivid scarlet flowers 10 to 12 inches in length. Continues to flower profusely all Summer and Fall. Of easy growth. The most popular Salvia in cultivation. Pkt. 10c., $1 / 4$ oz. $60 \mathrm{c}$, , oz. $\$ 2.00$.

Bonfire. Plants form sturdy bushes ahout 2 feet high by 2 feet across. Spikes grow erect and stand clear above the foliage, completely covering the plant, and are of a most brilliant, dazzling scarlet. One of the finest sorts. Pkt. 10c., 1/4 oz. 75c., oz. $\$ 2.50$.

Snapdragon (Antirrhinum). An old border and long spikes of curiously shaped, brilliantly colored flowers, having finely marked throats. They have been much improved of late years by careful selection. Snapdragons blossom the first season from seed sown in Spring, specially under frames. Fine mixed. Pkt. 10c.

Stocks (Gilliflower). The Stocks represent al plants have good habits, fine dull or glossy leaves. The flowers appear on long, stiff stalks like small rosettes, are exceedingly fragrant and range through a most complete scale of all the soft and distinct shades.

Large-Flowering Ten Weeks. A splendid earlyblooming variety extensively used for pot culture and for Summer bedding. 1 foot.

Dwarf Mixed. Pkt. 5c.

Sunflower See Helianthus.

Sweet Peas See page 42.

\section{Sweet William (Dianthus barbatus). A} flowering hardy perennial, producing a splendid effect in beds and borders with their rich and varied flowers. It is much better to raise new, vigorous, young plants from seed every season than to divide the old plants.

Perfection Single Fine Mixed. Large flowers of many beautiful colors and markings. Pkt. 5c., $1 / 4$ oz. $15 \mathrm{c}$.

Perfection Double Mixed. A fine mixture of double varieties. Pkt. 5c., $1 / 4$ oz. 20c.

Thunbergia (Black-eyed Susan). Beautiful, rapid-growing annual climbers, preferring a warm, sunny situation; used extensively in hanging baskets, vases, low fences, etc., very pretty flowers in buff, white, orange, etc., with dark red mixed colors; 4 feet. Pkt. 5c., 1/4 Oz 25c.

Violet Sweet-scented (Viola odorata). The Violet should not be wanting in any garden on account of its fragrance and early appearance. A single flower will perfume a whole room. Succeeds best in a shady, sheltered place and can be easily increased by dividing the roots. Hardy perennial. Pkt. 10c.

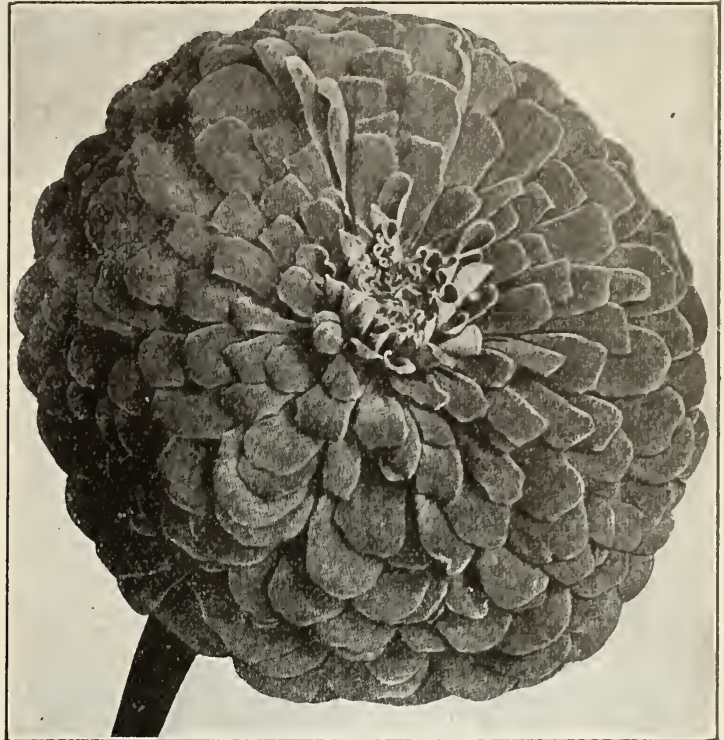

Schultz's "Double Giant" Zinnia

Verbena One of the finest bedding plants and also suitable for borders with its heads of brilliant colored flowers, producing one mass of bloom throughout the Summer. Seeds may be sown in March or April indoors and planted out when weather permits; succeeding well in any good garden soil.

Mammoth Mixed. Pkt. 10c., 1/4 oz. 50c.

Wallflower Wallflowers should be better known and outdoor bedding and the peculiar sweet fragrance of their flowers should win favor. The Oriental coloring of the flowers in their rich reds and yellows is very effective. They are easily grown and last long as cut flowers.

Single-Flowered Mixed. Pkt. 10c.

Wild Cucumber A climber which reaches a season. It is covered with clusters of white, sweetscented flowers, followed by an abundance of ornamental seed pods. Hardy annual. Pkt. 5c., oz. $15 \mathrm{c}$.

Zinnias Schultz's Giant Double (Youth and Old Age). A special strain of this grand old favorite free and continuous flowering annual, which produces flowers of colossal size, specimens measuring from 4 to 5 inches across being not unusual. Plants are of extremely robust habit, attaining a height of about 3 feet and bearing on long, strong stems numerous semi-globular, mostly very double flowers, all of the largest size, making them of great value in large beds, borders, etc.; grown under favorable conditions they remain in bloom from early Summer to late Autumn.

Giant Double Mixed. All colors. Pkt. 10c., $1 / 4$ oz. $25 \mathrm{c}, 0 \mathrm{z}, 75 \mathrm{c}$

\section{Bedding Plants for Spring Planting}

We do not deliver plants, nor send them by Parcel Post. Sold only f.o.b. store. Prices subject to change.

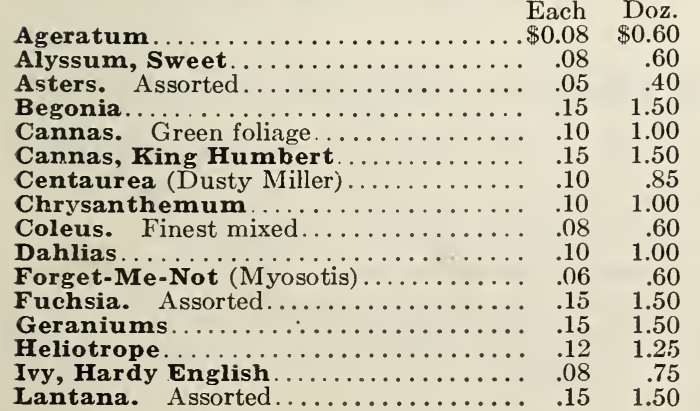

Lemon Verbena.

Each Doz.

Lemon

Marigold

$\$ 0.12 \$ 1.25$

Mignonette. Sweet-scented............. $10 \quad 1.00$

Moon Vines. .

Nasturtium. Diwarf $\cdots \cdots \cdots \cdots \cdots . .1806$

Pansies. Large, fancy, mixed............... $.05 \quad .50$

Petunia. Single sorts .............. .08 $\quad .75$

Petunia. Double sorts................. $15 \quad 1.50$

Phlox. Hardy ................. $15 \quad 1.50$

Phlox Drummondii $\ldots \ldots \ldots \ldots \ldots \ldots \ldots \ldots . .08 \ldots \ldots \ldots \ldots$

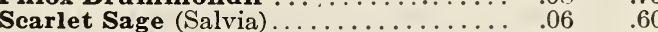

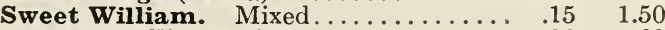

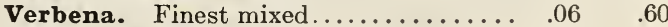

Vinca. Variegated leaf ................... $\quad .15 \quad 1.25$

Zinnia. Choicest mixed................... $.06 \quad .60$ 


\section{GIANT SPENCER SWEET PEAS}

These new Sweet Peas are distinguished for their gigantic size; usually-measuring 2 inches across; the bold, erect standards are uniformly waved, crimpled and fluted in exquisite fashion; the charming blendings of harmonious colors; the exceedingly long flower stems, which make them unexcelled for cutting; the great profusion of flowers and the large number of flowers on the stem, usually from three to four.

Cultural Note.-The seed should be sown in new ground as early as it can be worked in the Spring to enable the vines to make a good, strong growth before the hot weather sets in. White-seeded sorts should not be sown until the ground is comparatively dry and warm. Fall plantings give the best bloom; plant in October and November in trenches about 6 inches deep and cover to a depth of 3 inches, still allowing the center of the trench to remain at least 3 inches below the level of the ground and they will become well rooted and grow off at the first opening of Spring and yield an abundance of bloom earlier and for a longer season than if planted in the Spring. Use plenty of well-rotted manure, and don't gather the blooms grudgingly-the more you pick them the longer and better they will bloom.

BLANCHE FERRY SPENCER. A giant type of Spencer form, with rose standard and wings; white, suffused and tinted with light pink. Pkt. 10c.; oz. $25 \mathrm{c} ., 1 / 4$ lb. $85 \mathrm{c}$., lb. $\$ 3.00$.

COUNTESS SPENCER. Bright, clear pink, a little deeper at edges. Pkt. 10c., oz. 25c., $1 / 4$ lb. 85c., lb. $\$ 3.00$.

DORIS USHER. Salmon-pink on cream ground. The flowers are of largest size, freely borne four on a stem. Pkt. 10c., Oz. 25c., $1 / 4$ lb. 85c., lb. $\$ 3.00$.

ELFRIDA PEARSON. An old favorite. The color is a lovely pink throughout, the buds and flowers being tinted with salmon-pink. Pkt. 10c., oz. 25c., 1/4 lb. $85 \mathrm{c} .$, lb. $\$ 3.00$.

FIERY CROSS. Having the appearance of live fire, color a scorching fire-red, or scarlet, which glitters in bright sunlight, and a variety absolutely sun-proof. The flowers are beautifully waved and fluted, usually three and four on long, stout stems. Pkt. 25c., oz. $50 \mathrm{c}$., $1 / 4 \mathrm{lb}$. $\$ 1.75$.

FLORENCE NIGHTINGALE. The largest and best lavender. Pkt. 10c., oz. 25c., $1 / 4$ lb. 85c., lb. $\$ 3.00$.

HELEN LEWIS. Large, wavy, orange-pink. Pkt. 10c., oz. 25 c., $1 / 4$ lb. 85 c., lb. $\$ 3.00$.

KING EDWARD SPENCER. The best, pure red Spencer; very large, with especially immense wings; pure sun-proof. Pkt. $10 \mathrm{c} .$, oz. $25 \mathrm{c}$., $1 / 4$ lb. $85 \mathrm{c}$., lb. $\$ 3.00$.

KING WHITE. The finest pure white Sweet Pea ever offered. The vines are extremely strong, flowers the largest, of the finest frilled type, while the color is of the purest white, and eclipses all other white Sweet Peas. Pkt. 10c., oz. 35c., $1 / 4$ lb. $\$ 1.25$, lb. $\$ 5.00$.

MARGARET ATLEE. A particularly fine variety of the duplex type; flowers of extraordinary size. The color is an exquisite shade of salmon pink perfectly suffused over a cream ground, the shade of pink being quite different from any yet seen. Pkt. 10c., oz. $25 \mathrm{c}$., $1 / 4 \mathrm{lb}$. $85 \mathrm{c}$., lb. $\$ 3.00$.

PRIMROSE SPENCER. The color is a distinct primrose, without the least trace of pink. Pkt. 10c., oz. $25 \mathrm{c}$., $1 / 4$ lb. 85 c., lb. $\$ 3.00$.

WEDGWOOD. Producing usually four flowers to a stem, of a unique shade of Wedgwood blue, and the finest Spencer form. Pkt. 10c., oz. $35 \mathrm{c}$., $1 / 4 \mathrm{lb}$ lb1.25, lb. $\$ 5.00$.

GIANT SPENCER VARIETIES MIXED. A very fine assortment of all the best varieties. It will produce a gorgeous display of most attractive flowers. Pkt. 10c., Oz. 25c., $1 / 4$ lb. 75 c., lb. $\$ 2.50$.

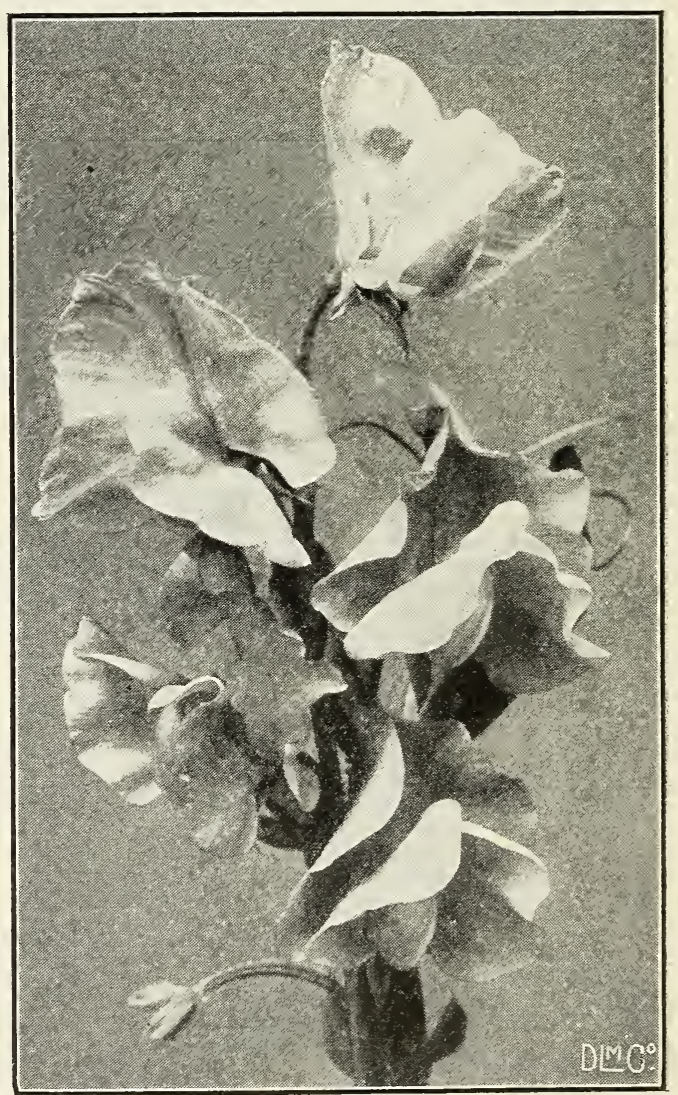

Sweet Peas-Spencer Type

\section{SWEET PEAS-Grandiflora or Standard Sorts}

PRICE: Pkt. 5c., oz. 20c., 1/4 1b. 45c., 1/2 1b. 75c., 1b. $\$ 1.50$, except where otherwise quoted.

Blanche Ferry. Popular pink and white. Dorothy Eckford. Large pure white. Hon. Mrs. E. Kenyon. Primrose yellow. Janet Scott. Clear deep, but bright pink. King Edward VII. Bright crimson; very large flowers. Lady Grisel Hamilton. Light lavender, sky-blue wings.
Miss Willmott. Orange pink, shaded rose.

Mrs. Collier. Light yellow, large flowers.

Prima Donna. Pure light pink; very fine.

FINEST GRANDIFLORA MIXTURE. All colors. A magnificent mixture of beautifully colored, largeflowering Sweet Peas. Pkt. 5c., oz. 15c., 1/4 lb. 30c., lb. $\$ 1.00$. 


\section{SUMMER-FLOWERING BULBS, RO0TS, ETC.}

Bulbs and Roots are not sent postpaid

There are few flowers that compare with the Dahlia in charning diversity of form and wide range of brilliant colors, and certainly no other surpasses it for Autumn display in the garden as well as for cutting.

\section{Decorative Dahlias}

Princess Juliana. Splendid new Holland decorative Dahlia. It is perfect as an exhibition flower, ideal for garden decoration and unsurpassed for cutting. Holland Dahlia specialists claim this the finest white Decorative Dahlia for cut flower purposes and also the best flowering. Received the Holland Dahlia Society's First-Class Certificate. 50c. each.

Dolly, or Sylvia. White, edged pink. 25c. each.

Souvenir de Gustave Doazon. It is the largest Dahlia in existence. The color is a pleasing shade of orange-red. Flowers are full to the center and of ten measure 9 inches and over in diameter; they can be forced to measure over 12 inches. Should be in every garden. 25c. each.

Jack Rose. The identical shade of the Rose with the same name. 25c. each.

Mme. Victor Vassier. The grandest, clear, sulphur yellow Decorative to date. 35c. each.

\section{Peony-Flowered Dahlias}

Queen Wilhelmina (Giant Holland Peony-flowered Dahlia). Largest and finest of the pure white sorts; excellent for decorative work and unsurpassed as a cut flower. An immense, fluffy flower of pure glistening white, showing its beautiful golden yellow center very prominently. 25c. each.

Madonna, or Baron G. de Grancy. A perfect wonder. Its remarkable qualities being excellent type, perfect form and purity of color. The color is a waxy, almost glistening, pure white. 50c. each.

Germania. Holland Peony-flowered Dahlia. Bright glowing crimson. 25c. each.

La Rainte. Up-to-date Peony-flowered Novelty. The color, a charming deep lavender-pink with an exquisite golden yellow center, combines to make the flowers most beautiful. 25c. each.

\section{Cactus Dahlias}

Stern. Bright primrose-yellow. The flowers are large; petals long and pointed. One of the most satisfactory varieties. $25 \mathrm{c}$. each.

Alight (Incurved). Gigantic flowers of a beautiful orange-scarlet color. Petals very long and exceedingly narrow. This variety can be highly recommended as a desirable form. 35c. each.

Eureka (Straight). Color, very deep purple. Petals are long, straight and tightly quilled. 25c. each.

J. H. Jackson (Straight). The finest black Cactus Dahlia in existence. Color, a perfectly gorgeous deep velvety blackish maroon. Gigantic in size. Every Dahlia lover should grow this variety. 25c. each.

\section{Show Dahlias}

Vivian. A great favorite which received the admiration of everyone who saw its wonderful flowers, the color being white, effectively edged rose-violet. One of our champions of this season's introductions and a variety worthy of the highest words of praise. $25 \mathrm{c}$. each.

Robert Broomfield. Pure white. Tall grower. 25c. each.

Arabella. Sulphur yellow, tipped pinkish white 25c. each.

Storm King. The most reliable white Show Dahlia to date. Color, a pure white. Flowers produced on good stems, well above the foliage. Free flowering. $25 \mathrm{c}$. each.

Stradella. Beautiful deep purple-crimson. Exceptionally free flowering. Stems long and wiry. One of the finest to date. $25 \mathrm{c}$. each.

\section{Single Dahlias}

Rose Pink Century. A rose-pink shade. 25c. each

\section{TUBEROSES}

Regular Grade. Each 7c., doz. 60c., $100 \$ 4.50$

Fancy Grade. Each 8c., doz. 75c., $100 \$ 6.00$.

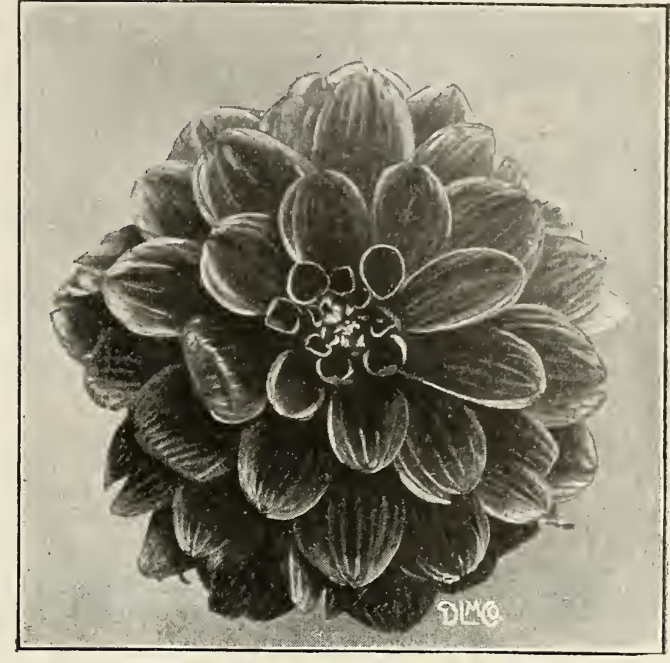

Decorative Dahlia Jack Rose

\section{GLADIOLI}

The Gladiolus is one of the most decorative plants in the garden, and as a cut flower lends itself readily to any arrangement. If the spikes are cut when the lowest flower is in bloom, the others will open in succession and remain fresh a week or ten days.

\section{NEW AND CHOICE NAMED VARIETIES}

America. One of the finest Gladioli known. The flowers are very large and of an exquisite shade of soft pink. Doz. 60c., $100, \$ 4.50$.

Baron Joseph Hulot. Deep indigo blue, slightly marked white at the base of the throat; very at tractive when arranged with yellow flowers in a vase. Each 10c., doz. $\$ 1.00$

Brenchleyensis. Vermilion scarlet; the best sort for planting in clumps among shrubs. Each 7c., doz. 60c Cracker Jack. Large flowers of velvety dark red throats spotted with yellow and dark maroon; a most sensational variety. $10 \mathrm{c}$. each, $\$ 1.00$ per doz

Glory of Holland. Very fine white, tinted rose Each 10c., doz. $\$ 1.00$.

Halley. Delightful salmon-rose with beautiful creamy blotch. Very large. 10c each, $\$ 1.00$ per doz.

Mrs. Francis King. Light scarlet of pleasing shade a beautiful variety. Each $7 \mathrm{c}$., doz. $75 \mathrm{c}$

Mrs. Frank Pendleton. Very large graceful blossom of lovely, bright pink, with rich carmine blotches on the lower petals; very beautiful. Each 15c., doz. $\$ 1.50$.

Niagara. Soft primrose-yellow, slightly tinged with rose-pink in throat. Each $12 \mathrm{c}$, doz $\$ 1.25$.

Panama. Beautiful, deep rose self, large flowers; fine spike. Each 15c., doz. \$1.50.

Peace. Large flower; white, with lilac blotch on lower petal. Each 12c., doz. \$1.25.

Schwaben. Light yellow, deep red blotch. Each 15c., doz. $\$ 1.50$.

Schultz's Rainbow Mixture Contains onty of our list. This gives a wide range named sor markings. We mix them ourselves and feel convinced they will please the most critical buyer. Doz. $\$ 1.00$, $100 \$ 7.50$.

CALADIUM ESCULENTUM

Mammoth Bulbs. Each 25c., doz. \$2.50.

Large Bulbs. Each 20c., doz. $\$ 2.00$. 


\section{Insecticides and Fungicides}

Marked * can be sent by Parcel Post. Prices Subject to Change Without Notice.

*Ant-i-Cide. The best and most effective remedy for ridding your lawn of ants. I.b. $30 \mathrm{c}$.

*Aphis Punk. A nicotine paper for fumigating greenhouses. Box 75c., case of 12 boxes $\$ 8.00$.

Arbo. An excellent combination fungicide and insecticide for general use on vegetables and fruits, except the Peach and Japanese Plum. Sticks like glue. Ready for use by mixing 1 lb. with 5 gals. cold water. Lb. 40c., 5 lbs. $\$ 1.60$, 10 lbs. $\$ 3.00$.

Arsenate of Lead (Paste). The best of all arsenical insecticides; for leafeating insects; does not burn the foliage. Dilute $1 \mathrm{oz}$. to 1 gal. of water. Lb. 35̃c., 5 lbs. $\$ 1.50$.

Arsenate of Lead (Powdered). Contains at least 33 per cent. arsenic. Superior to paste arsenate, stands suspension longer and has more covering capacity. $1 / 2$ lb. $40 \mathrm{c}$., lb. $75 \mathrm{c} ., 5 \mathrm{lbs}$. $\$ 3.00$.

"Black Leaf 40" (Sulphate of Nicotine). Highly recommended for destroying aphis, thrips, etc. without injury to foliage; $1 \mathrm{oz}$. makes 6 gals. Price $25 \mathrm{c} ., 1 / 2 \mathrm{lb} . \$ 1.00,2 \mathrm{lbs}$. $\$ 3.25$.

Bordeaux Mixture (Liquid). The supreme remedy against Fungus, Rust and Rot. 5 ozs. to 1 gal. of water is

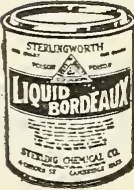
standard strength. Pt. 35c., qt. 50c.

Bordeaux Mixture (Dry). For dusting plants affected with mildew and all fungus diseases. Can be used as a spray. Lb. box 45̄c.; makes 5 gals. spray; 5 lbs. $\$ 1.75$.

Bordo-Lead. For Apples, Potatoes and general purposes, against leaf-eating insects and fungus diseases. It sticks to the foliage like paint in spite of heavy rains. Mix with cold water. Lb. 40 c., 5 lbs. $\$ 1.50$.

*Bug Death. A non-poisonous powder, sure death to Potato, Squash and Cucumber bugs, Currant and Tomato worms; can be applied either dry or in water Lb. 25c., 3 lbs. 60c., 5 lbs. 85c., $121 / 2$ lbs. $\$ 1.75$.

*Cut Worm Killer. Produces quick results and the niost effective cut worm killer yet introduced. It is non-poisonous to the user or animals. It is so alluring to cut worms that they are attracted to it in place of any vegetation. $1 \mathrm{lb}$. sufficient for 175 plants in hills and for 150 feet of drill. Lb. 30c., 5 lbs. $\$ 1.25$.

Fly Spray. Used as a spray; will relieve cattle. mules, horses and dogs from the effects of flies, gnats and mosquitoes. Qt. can 50c., gal. can $\$ 1.50,5$-gal. can $\$ 6.50$.

Hellebore. For currant worms and sucking insects. $1 / 4$ lb. 20c., $1 / 2$ lb. 35c., lb. 65 c., 5 lbs. $\$ 3.00$.

*Kerosene Emulsion. Used as a Summer wash against Scale, Plant Lice and Aphis. Dilute with water. Pt. 35c., qt. 60c., gal. $\$ 1.50$.

Lawn Compound (Sterlingworth). Kills the weeds in lawns without killing the grass. Destroys dandelions, plantain, chickweed and all weeds having broad or hairy leaves. 5-1b. cans $75 \mathrm{c}$.
Lemon Oil. One of the cheapest, safest and most effectual insecticides. Dilute with 40 to 50 parts water. An excellent wash for dogs, curing mange, killing insects. $1 / 2$ pt. $30 \mathrm{c} .$, pt. $50 \mathrm{c} .$, qt. $90 \mathrm{c}$.

Lime Sulphur Solution. A perfect scale and fungus destroyer, special for plum and peach trees which need Fall and Spring treatment. Cures Peach leaf curl. Qt. 40c., gal. \$1.25.

Lime Sulphur (Dry). This combination is a most ef fective remedy for scale or fungus troubles, used inFall and Winter; dilute with water. Lb. $25 \mathrm{c} ., 5 \mathrm{lbs}$. $\$ 1.00$.

Nikoteen. An economical and powerful Nicoteen extract. Effective remedy against Aphis and fly insects. Bottle $40 \mathrm{c}$., $1 / 2 \mathrm{lb}$. $85 \mathrm{c}$., lb. $\$ 1.50$.

No Scab. A formalin formaldehyde preparation for treating Potato and Grain seed to protect crop from Rot, Rust, Scab, Blight and Smut. 1 lb. makes 15 gals. Soak as many lots as required in same solution; good until used. Never plant Potatoes without first treating seed with No Scab. 1/2 lb. $50 \mathrm{c}$

Paris Green. For Potato bugs and other leaf-eating insects. Mix with Land Plaster, or use as a spray. $1 / 4$ lb. 25 c., 1/2 lb. 40 c., lb. 75 c., 5 lbs. $\$ 3.50$.

*Plant Lice Killer (Sterlingworth). Exclusively for use on house plants and vegetables infested with plant lice. Dilute 1 part to 15 parts water and apply as a fine spray. Pt. 30c., qt. 50c.

Pyrox. A combined insecticide and fungicide for all leaf-eating insects. Tsed largely by Potato growers. Lb. 40 c., 5 lbs. $\$ 1.50$.

*Slug Shot (Hammond's). Destroys insects and worms injurious to garden and house plants; Potatoes, Cabbage, Tobacco shrubs, trees, vegetables and fruits of all kinds. Positively not poisonous and will not injure the foliage. Lb. 23c., 5-lb. pkg. 69c., $50 \mathrm{lbs}$ $\$ 4.50,100$ lbs. $\$ 8.50$.

*Sulphur, Powdered. For mildew. Lb. 20c., 5 lbs. 60 c., 10 lbs. $\$ 1.00$.

*Tarred Felt Discs. For fitting around the stems of Cabbage and Cauliflower plants to protect them from root maggots. $10050 \mathrm{c}$., 1000 \$2.50.

*Tobacco Powder. For dusting plants affected with Aphis; also used on Squash vines and Melons. Lb. 20c., 5 lbs. 75 c., 25 lbs. $\$ 2.50$.

Tobacco Stems. For fumigating. Valuable as a mulch for Rose beds, Sweet Peas and other plants. Lb. 10c., 3 lbs. 25c. Bale about 80 lbs, $\$ 1.50$.

*Tree Tanglefoot. A sticky substance applied directly to the bark. To protect trees against climbing insect pests. One application remains sticky, fully exposed to weather, three months. $1 \mathrm{lb}$. will make a band 7 to 8 feet long. Lb. can 50c., 3 lbs. $\$ 1.50$.

Weed Killler. The method of killing weeds thoroughly by application of this liquid has become general. Used only on paths, drives, gutters and places where no growth is wanted. Lb. pkg. makes 15 gals., covers 45 to $60 \mathrm{sq}$. yds, $50 \mathrm{c}$.: 5 lbs. $\$ 2.00$.

*Whale Oil Soap and Tobacco. A very effective, simple and cheap preparation for the preservation of trees, shrubs, plants, vines, Rose bushes, etc. from the ravages of insects. Lb. 30c., 5 lbs. \$1.25.

*Whale or Fish Oil Soap. Used during the Summer as a wash, thus preventing the spread of scale. Lb. $30 \mathrm{c} ., 5 \mathrm{lbs}$. $\$ 1.25$. Special prices on large quantities.

\section{Spraying Outfits For Garden and Orchard}

Spraying crops for checking insects and diseases is absolutelv essential to the production of good marketable fruit and vegetables. Use a spraver with business-like energy and intelligence and the returns will be large dividends. Sprayers listed pages 48 and 49. 
Prices subject to change without notice.

\section{Queen Incubators}

\section{Stop Hatching Weak Chicks With Cheap Incubators}

\section{A Queen Costs But Little More and the Extra Chicks That Live and Grow Soon Pay the Difference.}

Remember, it is not how many chicks you hatch that counts, but how many you raise. Chicks that hatch out weak and wobbly, and live but a few days mean nothing to you but trouble and loss. They make one sick of the poultry business.

Iost of the chicks you lose in the first few weeks die because they did not have, when hatched, enough strength or vitality for a good start. Queen Incubators are famous the country over for big hatches of strong, healthy chicks that live and grow

Queen Incubators are not cheap, but they are cheap in the long run. They will be turning out good hatches years after the cheap machines have been junked.

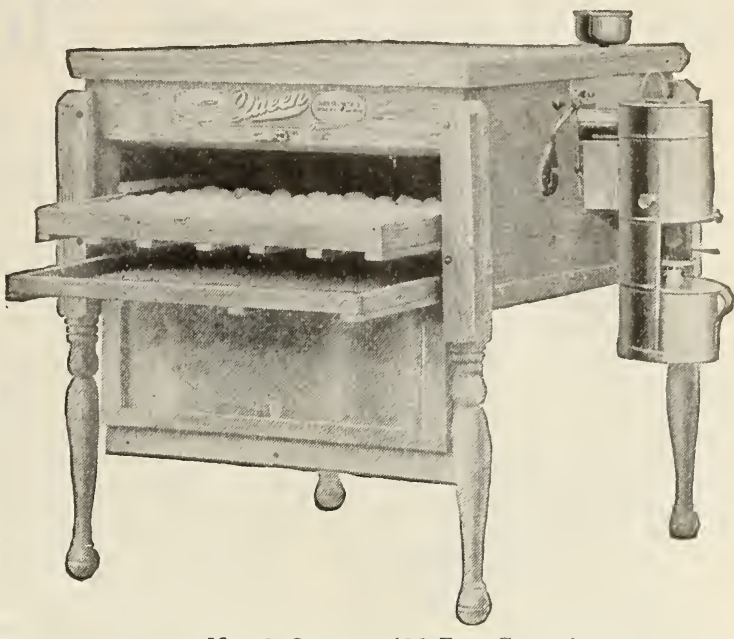

No. 2 Queen-135 Egg Capacity

SIZES AND PRICES-ASK FOR FREE CATALOG

No. 1 Queen - 85-egg size............. \$30.00

No. 2 Queen -135-egg size .............. 43.50

No. 3 Queen-180-egg size ............. 51.50

No. 4 Queen-275-egg size $\ldots \ldots \ldots \ldots \ldots \ldots \ldots, 65.00$
No. 5 Queen-400-egg size $\ldots \ldots \ldots \ldots \ldots \ldots$

No. 25 Queen-550-egg size

.

No. 22 Style $\mathbf{K}-220$-egg size ............. 43.50

\section{Queen Colony Brooder}

No. $1-600$ chick size

$\$ 25.50$ | No. $2-1200$ chick size

$\$ 31.50$

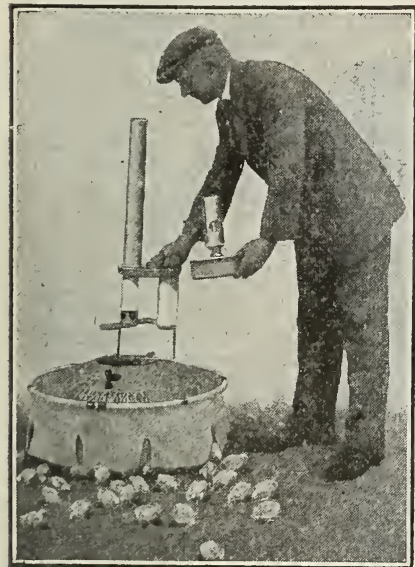

International Sanitary Hover

\section{International Sanitary Hovers}

The International Sanitary Hovers have stood every climatic test from Panama to Quebec. Practical poultrymen, state experiment stations, and poultry judges endorse them. You can raise chicks anywhere with International Sanitary Hovers. No specially constructed houses are necessary. There is no better place than in your regular hen houses. Sanitary Hovers are as practical for the small backyard poultry raiser as for large poultry farms. They are warmest at the curtain; usable anywhere; ready for busi. ness wherever placed. No crowding or smothering of chicks; no kneeling in mud to get at the lamp; no cutting of holes or building of platforms You want the best brooding device-you will get it in the Sanitary Hovers. rrice, $\$ 18.00$ each.

\section{Blue Hen Colony Brooders}

A very high grade type of hot air brooder. Whether amateur or professional, you can raise successfully 100 to 500 chicks with no more trouble than raising a handful. In thirty minutes it can be set up, adjusted and fire started. Requires no attention, except replenishing the coal and taking out the ashes. Fully guaranteed. Nothing flimsy about it. Made to stand hard usage and should last a lifetime. Its chief feature is the wonderful success in raising a very large percentage of strong, healthy chicks. Chicks get all the fresh, warmed air needed, and without floor draughts. Simple, safe, economical. Burns either hard or soft coal.

No. 43-350-chick size........... $\$ 25.00$

No. 44-500-chick size............................. 30.00

No. $45-1000$-chick size........................... 35.00

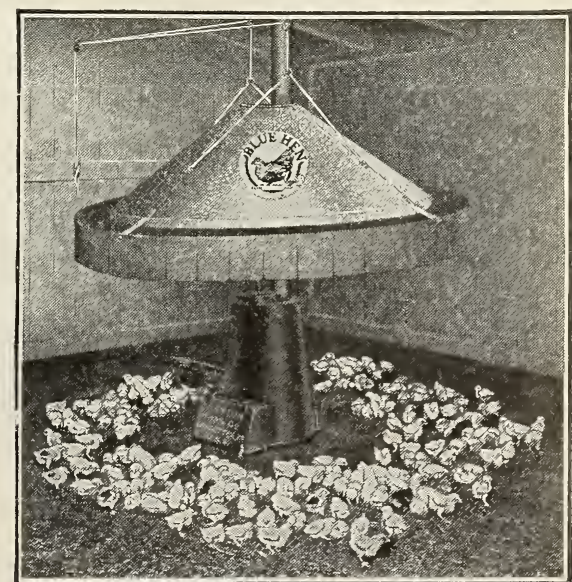

Blue Hen Hot Air Brooder 


\section{POULTRY}

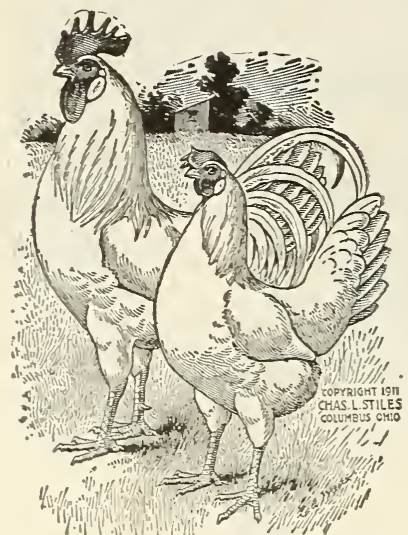

Single Comb White Leghorn

\section{and PIGEON Poultry Feeds}

\section{Contains no Grit or Shell}

Prices below subject to change without notice

Makem Lay Poultry Feeds are rapidly becoming recognized by successful poultry raisers as the standard for egg and flesh production. They are composed of choice grains and seeds, carefully selected as regards purity, cleanness, sweetness and freshness, and are mixed with such care that each mixture is a scientifically balanced ration for the purpose for which it is intended. They stand pre-eminent in the realm of poultry feeds today.
ON SUPPLIES

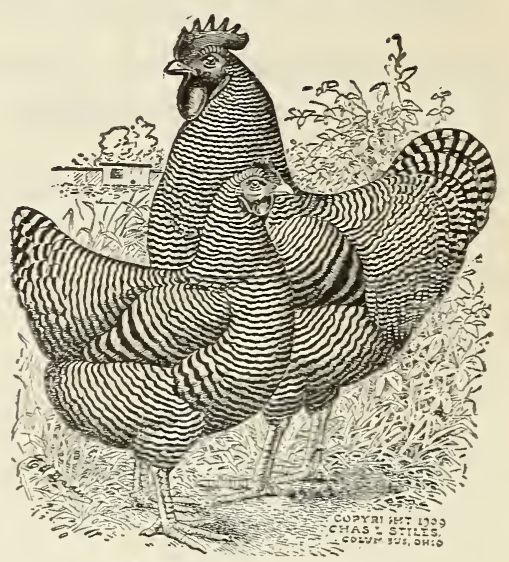

Barred Plymouth Rock
Makem Lay Poultry Feed. A combination of rarious grains, coarsely cracked. Just the thing to insure heary yield of fertile eggs. $10 \mathrm{lbs} .50 \mathrm{c} ., 50 \mathrm{lbs}$. $\$ 2.00,100-\mathrm{lb}$. bag $\$ 3.50$.

Makem Lay Mash Feed (Ready Mixed for Daily Mash). Is the best balanced ration for pullets, hens, cockerels, capons, ducks, turkeys or geese. It is made from the best selected grains and contains no oat hulls or waste. Can be fed steamed as well as dry. 10 lbs. 50c., 50 lbs. $\$ 2.00,100-\mathrm{lb}$. bag $\$ 3.50$.

Makem Grow Chick Feed. A carefully balanced mixture of many different seeds and grains proportioned to the needs of the growing chick. This food keeps chicks free from indigestion and bowel trouble. Will reduce the loss to a minimum. $10 \mathrm{lbs} .60 \mathrm{c}$., $50 \mathrm{lbs}$. $\$ 2.25$, 100-lb. bag \$3.75.

Makem Develop Feed. A dereloping food composed of whole grains and seed of the highest quality and especially adapted to the growing period and when used insures a strong and rapid growth. $10 \mathrm{lbs} .60 \mathrm{c}$., 50 lbs. $\$ 2.25,100$ lbs, $\$ 3.75$

Makem Grow Pigeon Feed. Composed of the very best hard red Winter wheat and other grains and seeds of equal quality. It is very strong in muscle and bone-making elements, and is so perfectly blanced that no organism is neglected. $10 \mathrm{lbs}$. $60 \mathrm{c} ., 501 \mathrm{bs}$. $\$ 2.35,100$ lbs. $\$ 4.25$.

Blatchford's Milk Mash. Saves the babr chicks by bringing the little fellows safely through the first ten-day danger period and promoting the three great essentials-early maturity, without forcing-increased weight, economically - and perfect health. $5 \mathrm{lbs} .35 \mathrm{c}$. 25 lbs. $\$ 1.50,100$ lbs. $\$ 5.25$.

Carbola. Disinfecting g erm-killing white paint. Use it instead of whitewash. Put on with a brush or sprayer. Trial pkg. 30c., 10 lbs. $\$ 1.25$.

Pratt's Baby Chick Food. Same preparation as Conkey's Starting Food. If these foods are used you will eliminate your diarrhœa trouble. Ib. 15c., 3 lbs. $35 \mathrm{c}$., 5 lbs, $60 \mathrm{c}$

Charcoal. Aids digestion and promotes health of chicks to a wonderful extent. Grade " $3 \mathrm{X}$," medium chick size, and grade " $4 \mathrm{X}$ " coarse granulated. Lb. cartons 10c., 5 lbs. 35c., 10 lbs. 60c., 50 lbs. \$2.00.

Crushed Oyster Shells. Important as an egg-shell maker and promoter of health. Our shell is clean and free from waste. No. 3 for chicks, No. 2 for adults. 10 lbs. 20c., 100 lbs. $\$ 1.25$.

Mica Spar Crystal Grit. One of the sharpest and hardest grits known. 10 lbs. 20c., 100 lbs. S1.2..

Beef Scraps. Made especially for us from healthy fresh meat.' A splendid Tinter food. 5 lbs. 35c., 10 lbs, 65c. 100 lbs, $\$ 5.25$

Pratt's Poultry Regulator. Excellent either for small chicks or large fowls. $11 / 2 \mathrm{lb}$. package $30 \mathrm{c}$. 5 lbs. 60c., 12 lbs. \$1.40.

Dr. Hess Poultry Pan-a-ce-a. Makes poultry healthy, makes hens lay; not a stimulant, but a tonic, that tones up the bird. $11 / 2 \mathrm{lb}$. package $30 \mathrm{c}, 5 \mathrm{lbs}$. $75 \mathrm{c} ., 12$ lbs. $\$ 1.50,25 \mathrm{lb}$. pail $\$ 3.00$.
Short Cut Alfalfa Clover. No mash is complete without it. Aside from food value, it has high medicinal properties. 95 per cent. pure Clover, 5 lbs. 25c., 10 lbs. 40c., 100 lbs. $\$ 2.75$.

Klean Drink Water Fountains. They are easily cleaned and filled. Any ordinary bottle or fruit jar can be used with them. No bottles or cans are included with Fountains. 30c. each. Postage, 10c.

Grit and Shell Boxes. This box is made of heary galvanized iron with three compartments for grit, shells and charcoal. 3 compartments, $\$ 1.25 ; 2$ compartments, (holds 10 qts.), $\$ 1.50$.

Stone Drinking Founts. These are most excellent for Summer use as they keep the water cool. They are constructed with a hood so that the chickens cannot foul the water. Pt. 20c., qt. 30c., 2 qts. 40c., 1 qts. 50 c., 8 qts. 60 c.

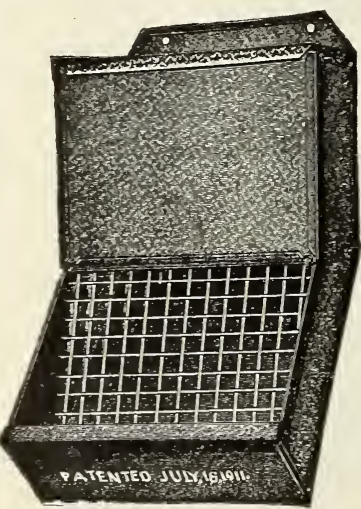

Sexton's Dry Mash Hopper. This hopper is arranged to hang on the wall the desired distance from the floor, and it is impossible to waste any feed, as the pan at the bottom takes any feed that may be picked out, and the last crumb can be used, thereby saving any waste. The body being corered, the feed is kept dust-proof and clean and is always dry. Body made of galranized iron, and the grating is of round galranized wire, preventing the poultry from cutting their bills. No. 1 , poultry size, each $\$ 1.75$.

\section{EGGS FOR HATCHING}

We contract each year with reliable breeders who have pens that are mated with careful attention to fertility of eggs. Shipments are carefully inspected, packed and forwarded by express.

The following strains are thoroughbred. They have been brought up to their present degree of perfection by careful breeding and selection, and the stock we send out is sure to give satisfaction. Per setting (15) Per 100 Single Comb White Leghorns. . . . . . . . $\$ 2.50 \quad \Sigma 5.50$ White Wrandottes.................. $2.50 \quad 10.00$ Barred Plymouth Rock............ 2.50 9.00

Rhode Island Red................... 2.50 9.00

Thite Plymouth Rock................. $2.50 \quad 9.00$

White and Buff Orpington............... 2.50 9.00 Per setting(11) Per 100

Giant Pekin Ducks. BABY CHICKS AND DUCKLINGS. We can supply Baby Chicks and Ducklings, of the abore breeds. Prices quoted on application. 
Prices Below Subject to Change without Notice

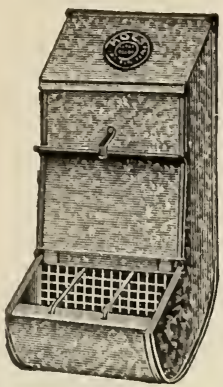

Favorite Dry Mash Hopper. The curved bottom of the hopper keeps the feed within easy reach of the birds. The gradual enlargement from the top to base prevents clogging. The wire grid and the wires running from the flange through the wire grid prevent any chance of the fowls throwing out or wasting, the feed. The sloping cover prevents the birds from roosting on the hopper, and when both covers are closed, it is rat and mouse proof.

12 in., 12 -qt. size.........\$1.75 18 in., 18-qt size ........... 2.25 FavGrite 1:ry Mash 24 in., 24-qt. size Hopper

Celluloid Leg Band. All the different colors. Celluloid leg bands are easily applied, are by far the best band used for designating old from young fowl, as the different colors can be seen from a distance. Doz. 20c., $100 \$ 1.00$.

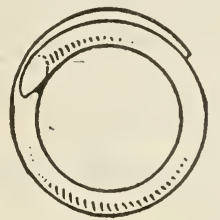

Leg Bands
Leader Adjustable Leg Band. Has neatest, most compact and smoothest fastening of any adjustable band on the market. Easily attached, absolutely secure and has no catching points. Doz. 20c., 25 35c., $100 \$ 1.00$

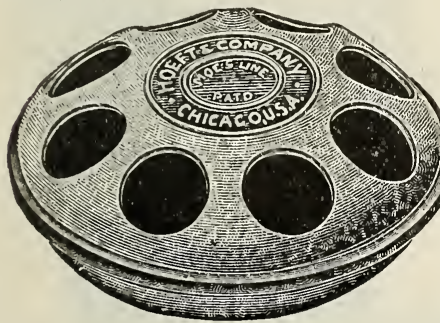

Round Baby Chick Feeder. A great feed saver, as the little chicks cannot get into it and contaminate the feed Cannot be upset. This is a practical well-made feeding device. Two sizes.

No. $11-6$ in in diameter, each $\ldots \ldots \ldots \ldots \ldots .25$ No. $12-81 / 4$ in. in diameter, each..................40

Poultry Punch. A poultry punch for marking baby chicks. Punches a clean hole in the web between the toes that will not bruise the foot. Guaranteed to work perfectly. Each $25 \mathrm{c}$.

Moe's Star Jar Fountain and Feeder. Will fit pint, quart or one-half gallon Mason jar. Manufactured of nne piece of non-rusting metal. Convenient, cheap and sanitary. Provides greater drinking surface than the round fountain. Little chicks cannot get drowned. One size only.

No. 32, without the

jar, each.......\$0.15

Thermometers. Incubator, from $75 \mathrm{c}$. to $\$ 1.25$; brooder, from $65 \mathrm{c}$. to $75 \mathrm{c}$

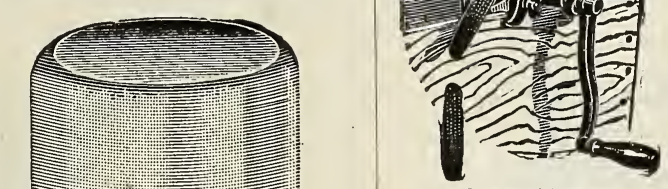

Corn Sheller

Red Chief Mill. The

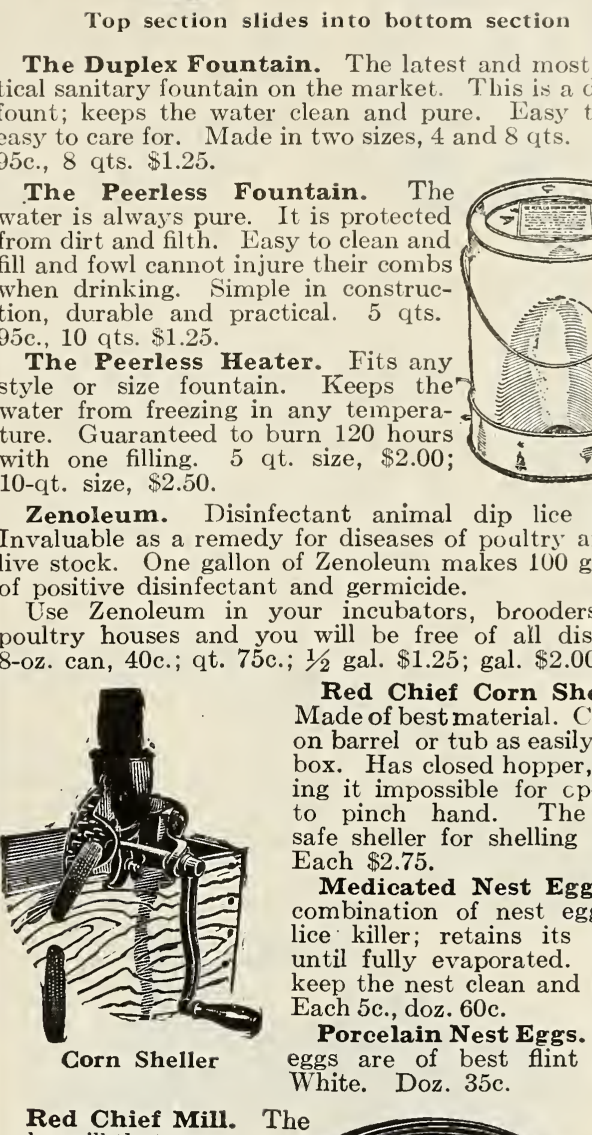

only mill that can

be used with good results either with or without the flat burr, and can be cleaned and adjusted in a moment's time withof a wrench An id e a l mill for cracking $\mathrm{gra}$ in of any kind for poultry and stock. No. 2, with crank $\$ 5.00$

No. 5, with balance wheel (see illustration) $\$ 7.00$.

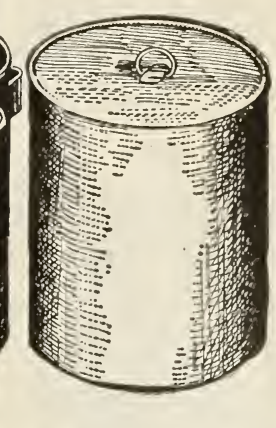

pracfill. CONKEY'S, DR. HESS' AND PRATTS POULTRY REMEDIES AND TONICS

Germozone, 85c. Roup Cure, 30c. and 60c. Lice Powder, 30c. and 60c. Lice Liquid, qt. 60c. Poultry Tonic, 30c. and 60c. Gape, 60c. Cholera, 30c. and Chicken Pox, 60c. Scaly Leg Cure, 60c. Head Lice Ointment, 15c. Bronchitis, 60c. Laying Tonic, $30 \mathrm{c}$. and 60c. Poultry Regulator, 30c. and 60c. Black Diamond Lice Killer, 30c.

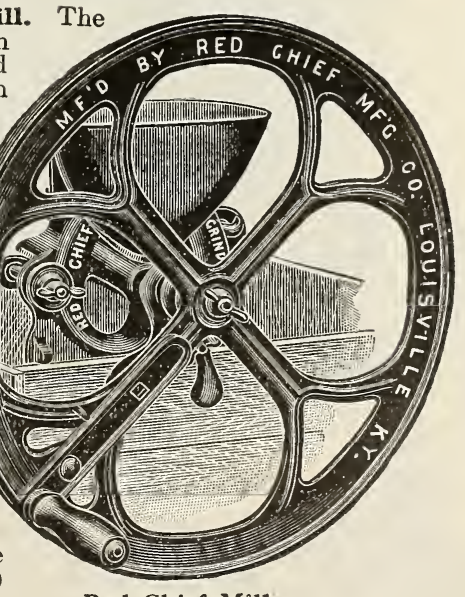

Red Chief Mill 

able fruit and vegetables. Conduct it with business-like energy asu intelligence and the returns will be large dividends. If you have only a small orchard it is not necessary to purchase a power outfit. The city man with a

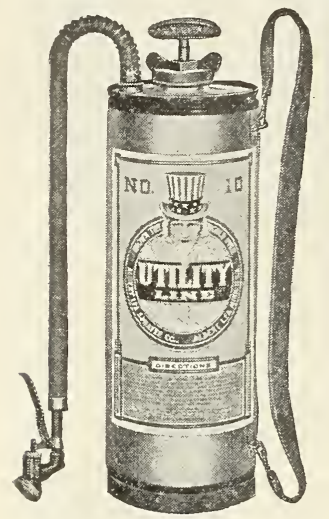
few bushes and small trees will only require a hand or bucket sprayer. For a man with a fair-sized orchard a barrel sprayer is satisfactory. For spraying Potatoes, Cantaloupes or other field crops, a field crop sprayer is an excellent machine. Spraying is a preventive of diseases and will not cure the disease when firmly established.

\section{Utility Compressed Air Sprayer}

The Utility is designed to meet the requirements of a high pressure sprayer convenient to handle and adapted to various uses. It will handle successfully, not only any kind of spray mixtures, but whitewash, kalsomine, cold water paint, glue for sizing and heavy creosote disinfectants. This makes it a favorite with the farmer, gardener, orchardist, poultry and stock growers. The tank has a capacity of $31 / 2$ gallons. The pump is constructed of heavy brass tubing $13 / 4$ inches in diameter, has a brass ball check valve, thereby aliminating the trouble incident to rubber or leather valves and springs. No. 10 , galvanized, $\$ 6.50 ;$ No. 15 , brass, $\$ 10.00$.

\section{Gould's "Pomona" Barrel Sprayer}

Fig. 1100

The "Pomona" has sufficient capacity to supply two leads of hose and four nozzles. The plunger, plunger connection, gland, valves, valve seats and strainer are of solid bronze. All working parts are simple and so located that they can be easily removed and cleaned. The air chamber is of steel and has a large capacity, making it easy to maintain the pressure and giving smooth operation. The lever can be adjusted for a 3 , 4 or 5 -inch stroke, the adjustment being obtained by removing and replacing a single bolt.

The agitator is very simple but effective, and is operated by the pump lever. This pump is fitted for mounting on the end of the barrel only, where it is held firmly in place by a barrel plate and small anchor at the bottom of the barrel. The plate is adjustable so that the pump can be used in barrels of ordinary depth.

Outfit C. With agitator and one lead, 15 feet, $3 / 8$-inch discharge hose, with "Nistry Jr." spray nozzle, \$28.25.

\section{Lowell Fountain Compressed Air Sprayer}

It is devoid of complex or intricate parts and is the easiest understood Compressed Air Sprayer in the world. It is so simple in construction that a child can operate it. Tree attachment and funnel, for filling, with brass wire strainer, with each machine. Capacity of tank, 3 gals. Handy to carry; Galvanized steel, No. 110 $\$ 7.00$ each; No. 111 , brass, $\$ 10.00$ each.

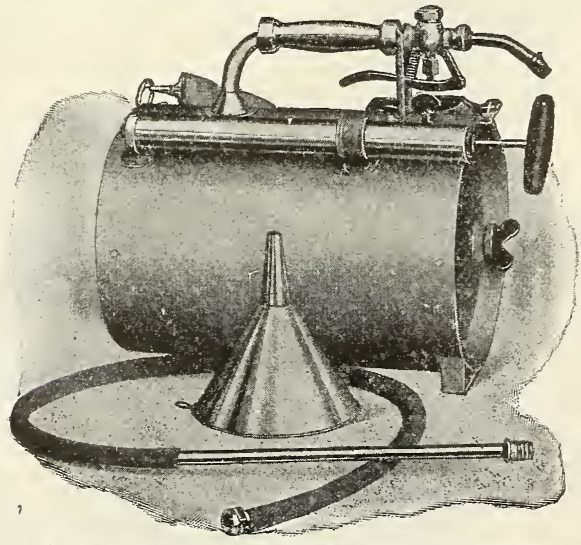

Lowell Fountain Compressed Air Sprayer

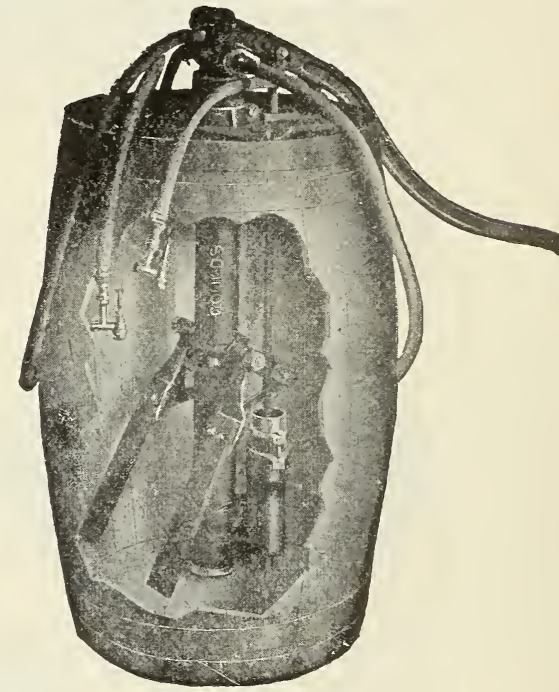

Fig. 1100-With Barrel

No. 40 Utility Portable Sprayer

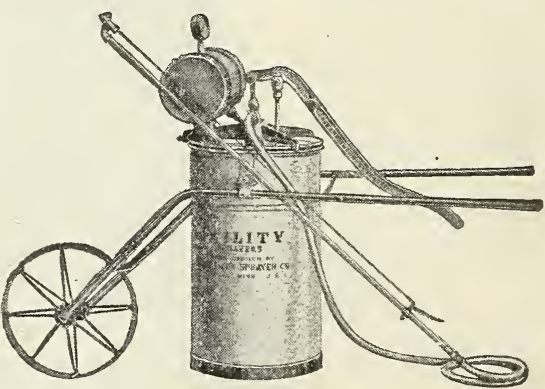

These outfits are very popular with all classes o trade interested in spraying, owing to the various uses to which they are adapted. Being practicable and so well designed they are especially popular with the farmer or grower that desires an outfit that can be used for spraying, for whitewashing, or disinfecting, as may be desired. For spraying of orchards, gardens or shrubbery, they have no equal. Price $\$ 22.50$.

\section{"Auto Spray" No. 1}

Auto-Pop Spray Nozzle with Hose and Fittings. Simply closing the hand operates the lever, opens the valve. The lever closes automatically; the spray is in perfect control...... \$2.50

Auto-Spray, No. 1A. Brass tank with stop cock 11.50 Auto-Spray, No. 1B. Brass tank with auto-pop. 12.00
Auto-Spray, No. 1C. Galvanized tank with stopcock.............................. $\$ 80$ Auto-Spray, No. 1D. Galvanized tank with auto-pop........................ 9.00

Brass Extension. $2 \mathrm{ft} \ldots \ldots \ldots \ldots \ldots \ldots \ldots \ldots, 60$

Brass Strainer.................... 1.50 


\section{to-Spray}

No. 37

\section{Defiance Bucket Spray Pump}

This pump is made entirely of brass with the exception of the foot rest and handle, has brass ball valves and patent agitator. The hose is detachable. The pump is well made throughout, has hemp packed plunger. The piston rod is a hollow tube, and forms a part of the air chamber, cushioning the stream. The main air chamber on the side of the pump is connected up to the main body of the cylinder by means of a slip joint tightly packed. The air chamber is sufficient to give a continuous stream making a most perfect double acting bucket spray pump, easy to operate.

Price, each $\$ 7.00$.

\section{Little Giant Brass Spray Pump}

With agitator, complete with hose and combination fine, coarse spray and solid stream nozzle, with malleable foot rest. Price, $\$ 6.00$.

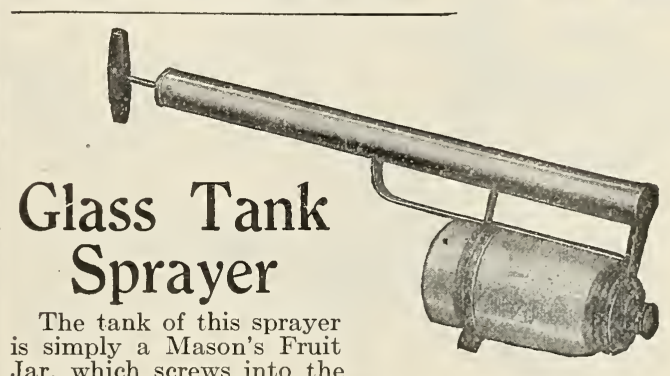
Jar, which screws into the cap of the sprayer. It is easily detached, and easily cleaned. This sprayer has double system of air chambers which makes the same amount of solution cover about twice the surface with less strokes of the plunger. Receptacle, being of glass, cannot corrode, and if broken is easily replaced. Price, each $\$ 1.00$.

No. 112. Tin tube and tank, plain. Each 50c.

\section{PUMPS. Goulds “Star” Anti-Freezing Force Pumps}

These pumps are built with revolving top, fitted with air-chamber tube and brass gland. The polished rod connects to the lever with a link. An outlet is provided back of the spout, tapped for iron pipe connection. The stock is tapped for pipe near the spout. Spout is flanged and bolted and furnished with nut and hose tube. Pumps as listed are 4 feet long from base to bottom of the cylinder and are suitable for wells about 30 feet deep. If wanted for wells of greater depth, add sufficient pipe and rod between base and cylinder to place the cylinder within 15 feet of the water. We recommend the use of foot valves and strainers with these pumps.

Fig. 8521/2. "Star" Force Pump, as described above.

Fig. 8821/2. This Pump is the same as Fig. $8521 / 2$, but fitted with Cock Spout.

\section{Pitcher-Spout Pumps For Suction Lift}

The Standard Closed-Top Pump supplies the demand for a low-priced but substantial pump for use over shallow wells, cisterns or drive wells. To prevent freezing raise the lever to extreme height, which permits the water to leave the cylinder.

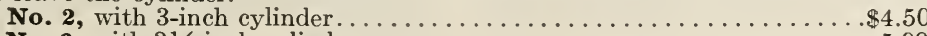

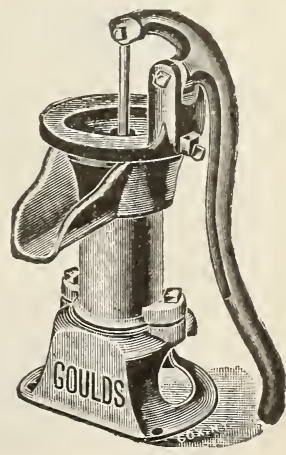


Schultz's Seed Store, Washington, D. C. IRON AGE ${ }_{\text {TOOLIS }}^{\text {GORDN }}$

Are best because they have high steel wheels, light weight steel frames, the quickest, easiest scouring side hoes, the most combinations from which to choose what you need, and the largest number of attachments for special work.
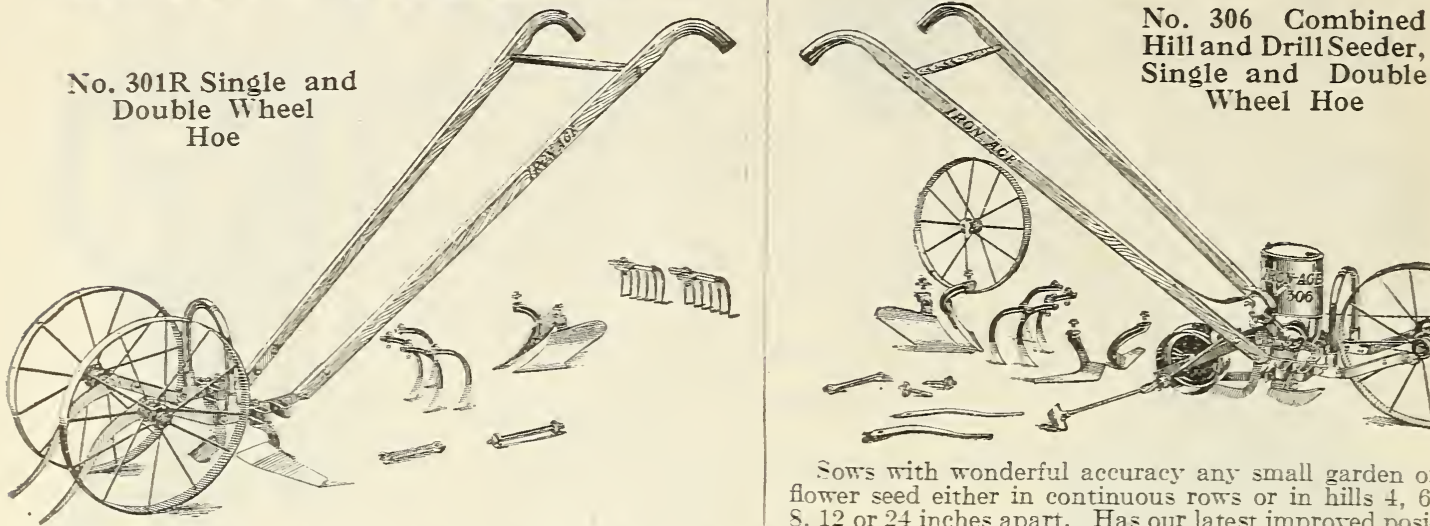

Same as To. 306, but without seeder attachment. Torks either astride or between rows. Tools adjustable on frame. Will open or close furrows, ridge crops, cultirate. hoe to or from plants, pulrerize, lerel soil etc. Easily worked. Long hardwood handles with full plow-shaped grips, do not tire out or make the hands sore. Handles adjustable to height of user. Price $=15.50$

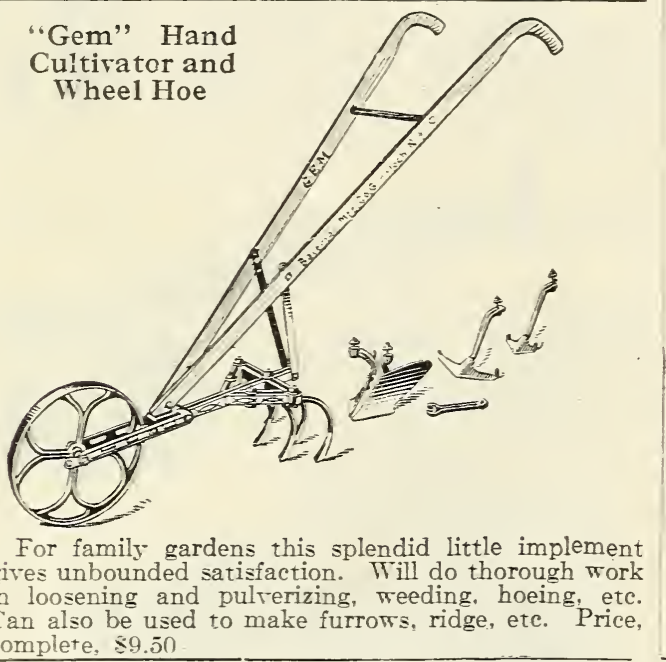

$$
\text { er. }
$$

For family gardens this splendid little implement gives unbounded satisfaction. Will do thorough work in loosening and pulterizing, weeding, hoeing, etc. Can also be used to make furrows, ridge, etc. Price, complete, $\$ 9.50$

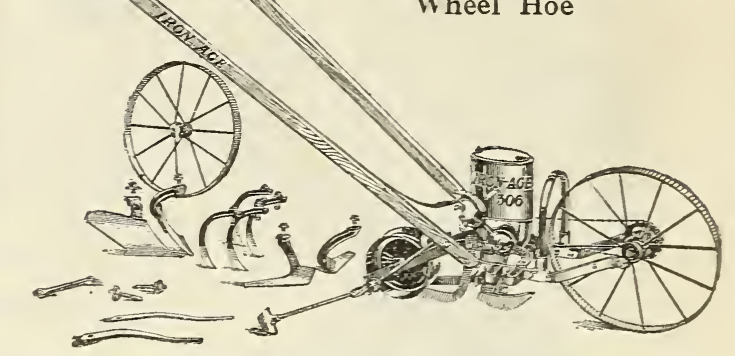

Sows with wonderful accuracy any small garden or flower seed either in continuous rows or in hills $t, 6$, 8,12 or 24 inches apart. Has our latest improred positive force feed. Will not injure seed. Index can be set to sow exactly as you want it. As a seeder, it opens furrow, plants seed in hills or drills, covers seed, packs soil and marks next row, all in one operation. Has long hardwood handles, with full plow-shaped grips. Seed hopper can be easily removed and any of the accompanying tools attached making either a double or single wheel hoe, same as No. 301. Capacity of seed hopper. 2 quarts. Price $\$ 24.25$.

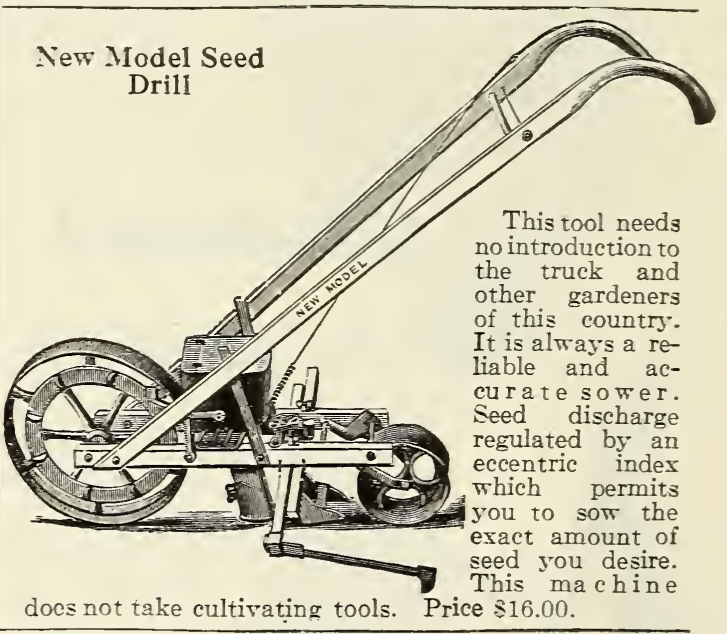

docs not take cultivating tools. Price $\$ 16.00$.

No. 19-C

Wheel

Cultivator and Plow

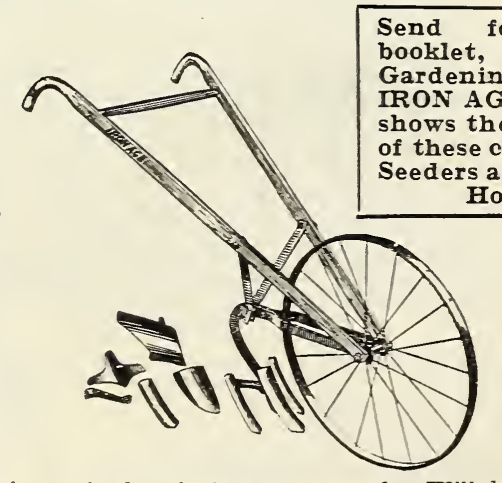

A popular, low-priced tool of great strength. Will do plowing in light soils, will open furrows for seed or fertilizer. Complete set of tools as shown in illustration. The 24-inch wheel travels easily over rough ground. A very practical tool, easily operated by men, women or children, and will last a long time. Price $\$ 7.50$. 


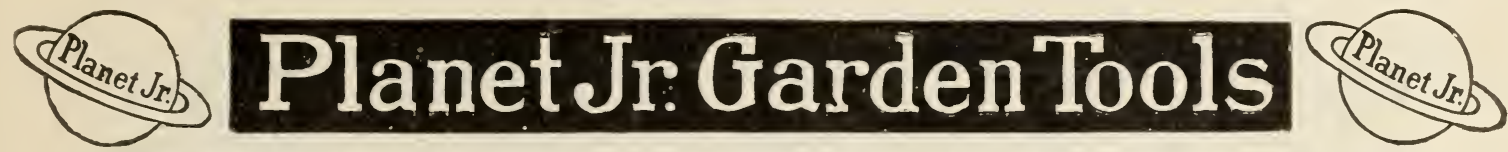

The New "PLANET JR." Catalogue is the handsomest, best, and most instructive book ever issued on a similar subject. Full of little points that bring profit. Full of true and handsome illustrations. We mail it free to any address on application.

No. 4 Planet Jr. Combined Hill and Drill Seeder, Wheel Hoe, Cultivator and Plow

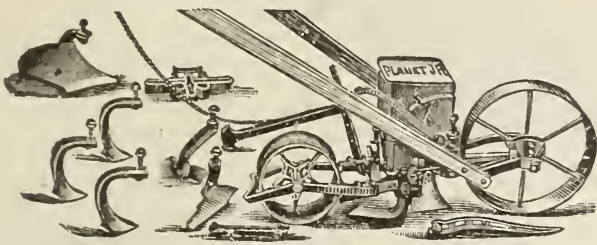

This tool combines, in a single convenient implement, a capital hill-dropping seeder, a continuous row seeder and admirable single wheel hoe, an excellent furrower, a capital wheel cultivator, and a rapid and efficient wheel garden plow.

Price, complete.

As a Seeder only.

$\$ 23.50$

No. 12 Double Wheel Hoe, Cultivator and Plow

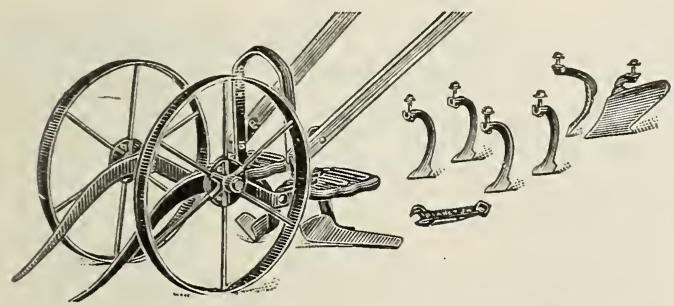

The Planet Jr. Double Wheel Hoes are the greatest cultivating tools in the world for every grower of garden crops from drilled seed. They do more and do it better and easier than can possibly be done in any other way. The frame is steel. Weight, $32 \mathrm{lbs}$. Price \$15.50.

No. 17 Planet Jr. Single Wheel Hoe

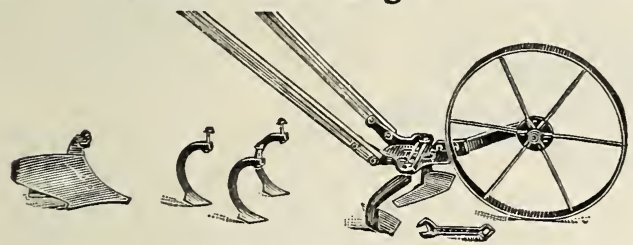

You can do more and better hoeing with it in one day than you can do in three days with a hand hoe. The No. 17 has a pair of 6 -inch hoes, a plow and a set of cultivator teeth, an outfit sufficient for most garden work. Price $\$ 10.75$.

No. 171/2 Planet Jr. Single Wheel Hoe

This tool is identical with No. 17 , except in equipment. The pair of 6 -inch hoes, three cultivator teeth and leaf lifter which go with it are all the finest of their kind. Price $\$ 9.15$.
No. 25 Planet Jr., Combined Hill and Drill Seeder and Double Wheel Hoe, Cultivator and Plow

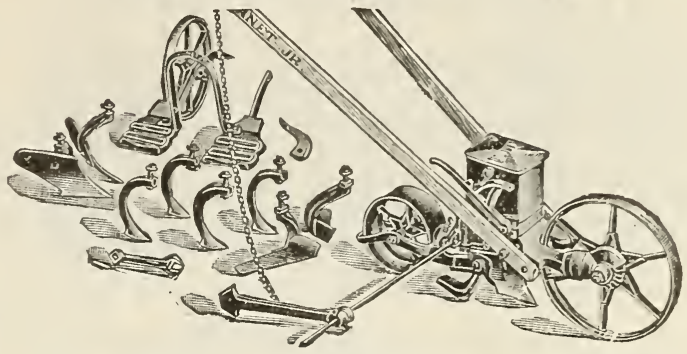

This new combined machine is intended for gardeners who have a large enough acreage in crops for a Double Wheel Hoe to be used to good advantage, and vet prafer not to buy seeders and wheel hoes separately. Price $\$ 26.50$.

No. 31 Combined Drill Seeder and Single Wheel Hoe

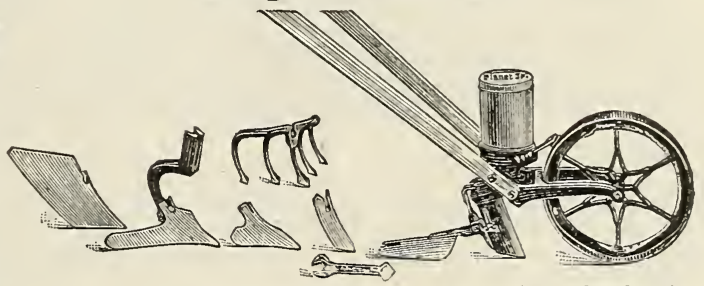

The whole combination will delight the suburbanite or equally the growing boy who knows that a certain amount of garden work is to be part of his service. Women, younger or older, will find in this tool a light running wheel hoe that will save them hard work and help much to supply the table with fine vegetables. Price \$15.50; \$12.50 as a Seeder only (No. 31D); \$8.00 as a Wheel Hoe only (No. 33).

No. 9 Planet Jr. Horse Hoe and Cultivator

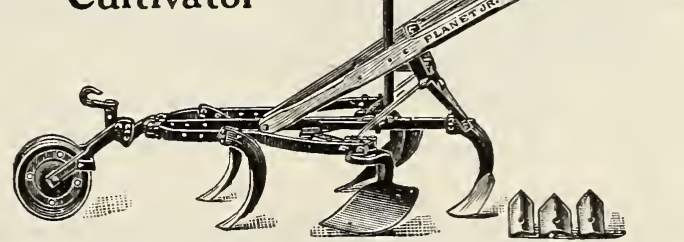

No other cultivating machine is so widely known as the Planet Jr. Combined Horse Hoe and Cultivator, for it is in use throughout the civilized world. It is so strongly built as to withstand incredible strain, yet it is light and easy to handle. Price $\$ 21.50$.

\section{PRICE LIST OF OTHER PLANET JR. TOOLS}

Planet Jr. No. 2 Seed Drill.

Planet Jr. No. 2 Seed Drill. Hoe, with 2 pairs hoes, 2 pairs cultivator teeth, 2 pairs rakes, 1 pair plows and 1 pair leaf lifters.

Improved Planet Jr. White Potato Digger

Planet Jr. No. 13 Wheel Hoe. Double Wheel Hoe, with 1 pair hoes only Price

Planet Jr. No. 16 Wheel Hoe. Single Wheel

Hoe, with 1 pair hoes, 3 cultivator teeth, 2 rakes, 1 plow and 1 leaf lifter.

Double Celery and Asparagus Hiller. 


\section{as \\ Page Lawn, Poultry and Field Fence}

At the time of going to press with this catalogue the wire market is so unsettled that we are unable to name any prices. We will continue to carry the styles of wire listed and will be pleased to quote rrices upon application.

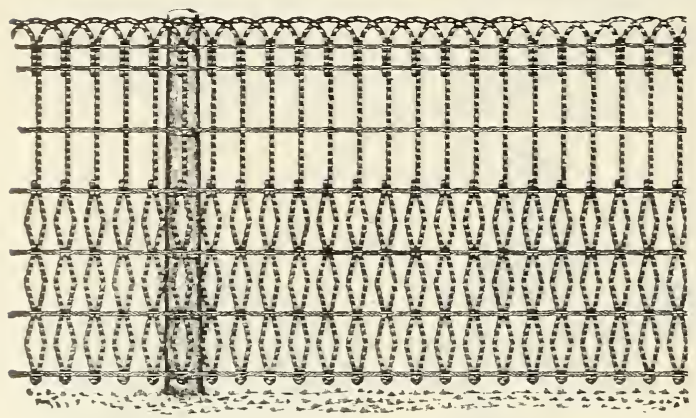

UNIFORM AND HEAVILY GALVANIZED HIGHEST GRADE OBTAINABLE

STYLE J. W. P. FABRIC FOR LAWNS OR GARDENS

The J. $\Pi$. P. Lawn Fence combines the beauty of a crimped picket and curved top together with a close mesh at the bottom, made by means of special shaped pickets, as shown in cut.

This fence is made with 3 -in. mesh at the top, with the three bottom spaces split as shown in illustration, thus providing our trade with a fence close enough at the bottom to turn chickens, and a design that will appeal to fence users because of its esceptional beauty:

Only the best grade of GALVANIZED wire is used, but in order to insure the longest life possible as well as add to the appearance of the fabric, we cover same with a coat of white paint.

SPECIFICATION-WIRE. First grade galvanized No. 9 Crimped uprights. No. 121/2 gauge cabled horizontals. PRICE LIST OF J. W. P. FABRIC

Height. 36 in 42 in.

....... 45 in in

co in.
Single Gates.
$3 \mathrm{ft}$

$3 \mathrm{ft} . \mathrm{s} \mathrm{ft}$.

\section{ECONOMY FABRIC ON WOOD POSTS WITH WOOD RAILS}

This fabric is frequently used without rail, the doublestrength top acting as a guard where strength is most needed. Made in all heights, from 24 inches up to 118 inches, and in two meshes, 3 and $21 / 4$ inches between pichets.

There is no longer an excuse for using cheap-looking field fence in front of or around residences, where at a slight additional expense an economr fabric can be used with the same posts and improve the surroundings more than ten times what any other improvement would do we could mention.

\section{PRICE LIST OF ECONOMY FABRIC}

Height.................. 42 in single Gates

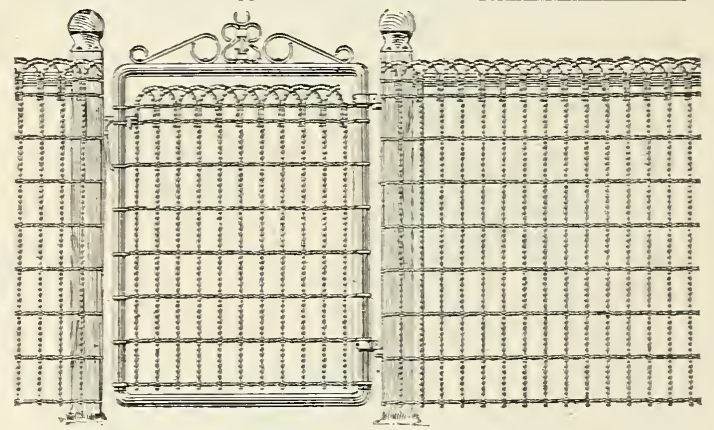
45 in
.54 in
$60 \mathrm{in}$,

PAGE LION POULTRY FENCE This fence is strong and substantial, sufficiently

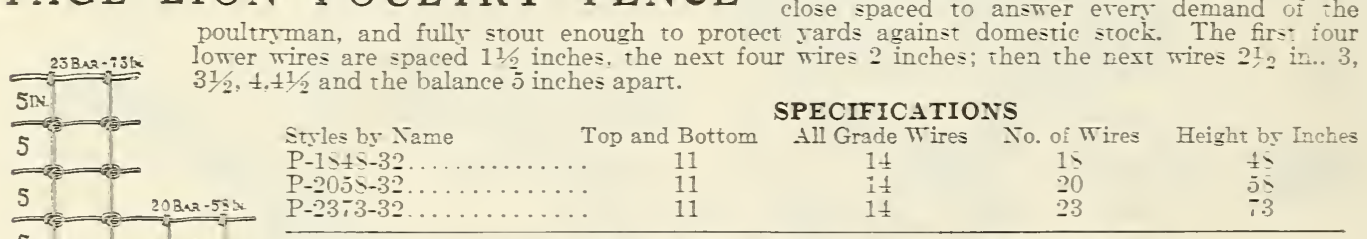

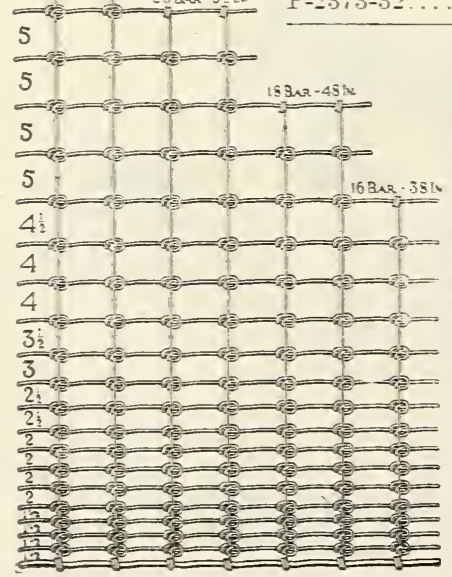

Page Lion Poultry Fence
PAGE LION WOVEN WIRE FENCE HOG, SHEEP, DAIRY AND GENERAL STOCK FENCES Among the "staple" fences, so called, we believe the LION is rightly named. Every wire from top to bottom and from end to end-line wires. cross wires and locks-is of a Hearth steel, heavily galranized, and an examination of the tie will, we think. impress any farmer with its superior features. Firm but not rigid, simple but strong, Te beliere it is the smoothest, safest and surest staple tie on the
market. It will not slide, slip, fall off or injure stock.

The Lion adapts itself to the lay of the land, and will outwear any other taple fence on the market.

Gates-Wire Gates of our regular patterns, both double and single. can secured for use with Lion Fences.

Barb Wire, Twisted Two-Strand Wire, Plain Galvanized Wire Prices on appdication. 


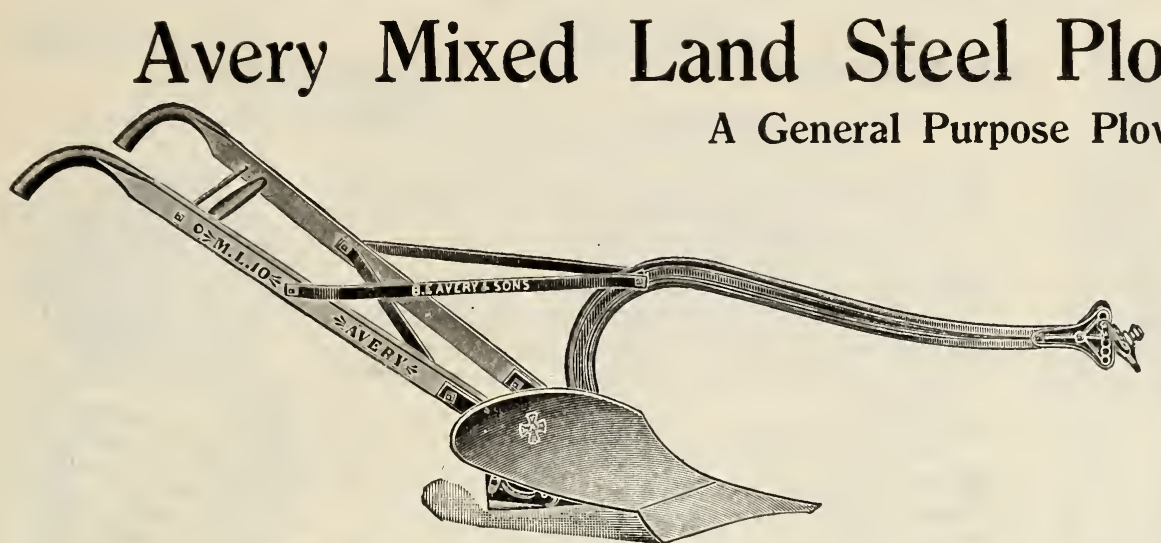

\section{Avery Mixed Land Steel Plows}

\section{A General Purpose Plow}

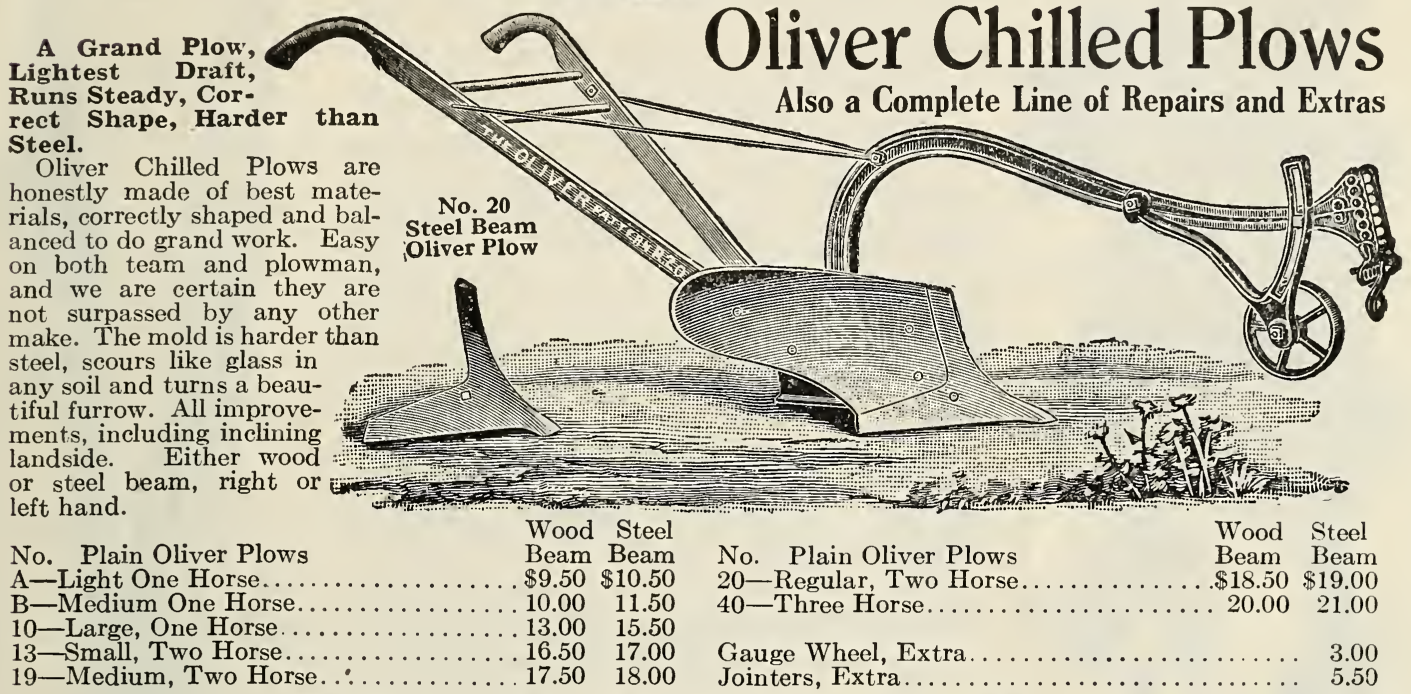

\section{Adjustable Spike Tooth Lever}

This Harrow has a frame of I-beam steel bars of " $U$ " shaped steel, well braced and securely fastened at each end to the frame, which gives strength and rigiditity, and as a guard against catching into trees and stumps. The teeth are of diamond shape steel. The runners are formed by the curved tooth extensions, which are placed so that the Harrow will free itself from trash.

The teeth are held firmly by a welded eye steel bolt through the slip malleable to roller bar, also the end teeth on the roller bars, which locks and bolts the frame firmly together. Each tooth cuts its own course, and can be raised or lowered as desired, and with the lever the teeth can be set to any pitch or cut desired. Price, 25 -tooth, 1 section, $\$ 13.00 ; 30$-tooth, 1 section, $\$ 14.00 ; 50$-tooth, 2 sections, $\$ 25.00 ; 60$-tooth, 2 sections, $\$ 26.00$.

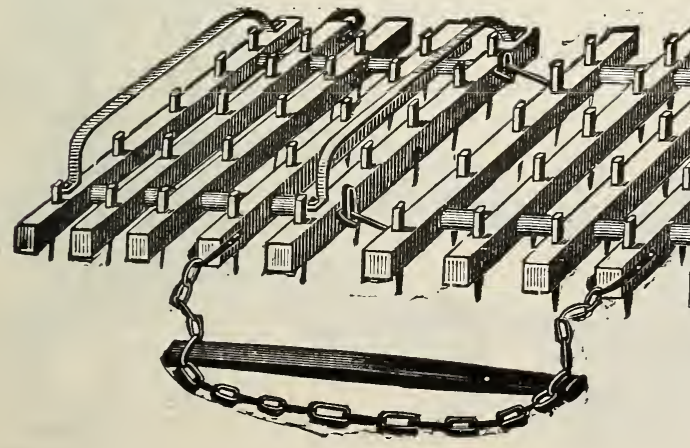

Double Hinge Harrow

(2 Horse)

This is a two-section, wood frame spiked-tooth Harrow. The runners, as seen in the cut, are intended to be used in carrying the Harrow from one field to another. Price, 40-tooth, $\$ 16.50 ; 50$-tooth, $\$ 18.50$.

\section{Gardener's Harrow}

(1 Horse)

This Harrow is similar to the Baltimore Double Hinge Harrow, only it is made in one section instead of two. We furnish this Harrow with 25 teeth, cutting 3 feet 8 inches wide. Price, with 25 teeth, $\$ 11.00$. 


\section{Schultz's Seed Store, Washington, D. C.}
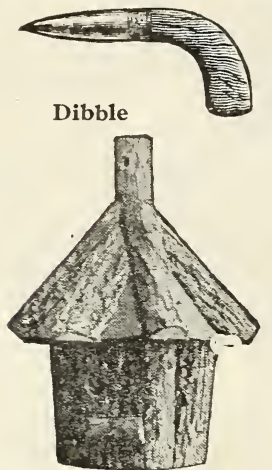

Rustic Bird House
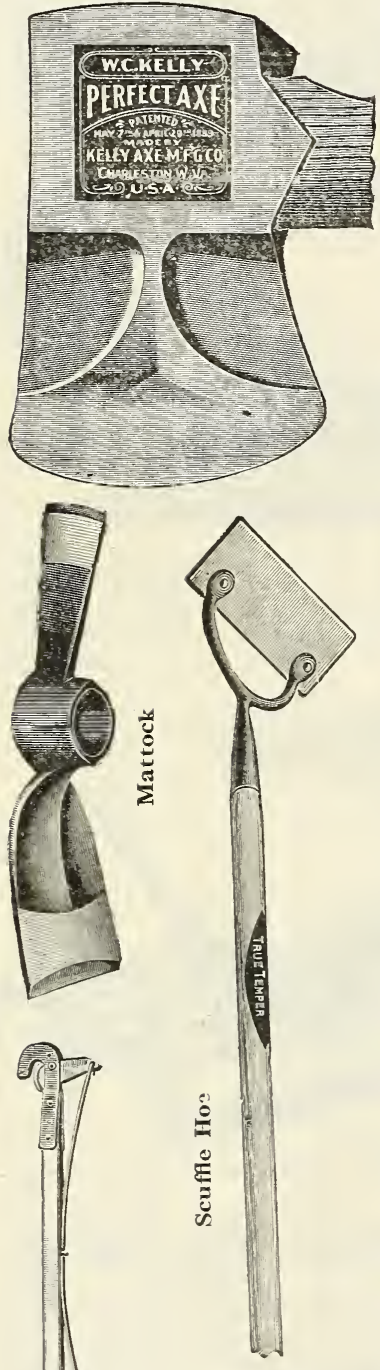

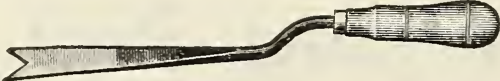

American Asparagus Knife

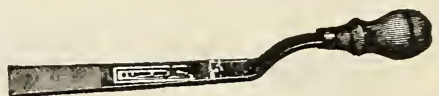

Bateman Asparagus Knife

\section{Horticultural Tools and Requisities}

\section{Prices subject to change without notice}

Asparagus Knife. American, 55c.; Bateman, 50c.

Axe. Best quality. Heavy, $\$ 2.00$; medium, $\$ 1.75$.

Bellows, Woodason's Powder. Large, double cone, $\$ 3.00$; large, single cone, $\$ 2.00$; small, single cone, $\$ 1.00$.

Bird Houses, Rustic. Wren's Log Cabin, 75c; Blue Bird House, \$1.25; Robin's Nest, $\$ 1.00$.

Dibble. Iron point, $40 \mathrm{c}$.

Flower Guard. Height 18 inches. Per foot, 15c.

Flower Pots. 4 inches, 6c.; 6 inch, 8 c.; 8 inch, 12c. ; 10 inch, $25 \mathrm{c}$.

Forks, Spading. D handle, 4 tine, best quality, $\$ 2.25$, next grade, $\$ 1.75$.

Manure. D handle, oval tines, strapped handle. 4 tine, $\$ 1.25 ; 5$ tine, $\$ 1.50$.

Manure. D handle, diamond tine, strapped handle. 4 tine, $\$ 2.00 ; 5$ tine, $\$ 2.50$.

Manure. Long handle, regular strapped, 4 tine, $\$ 1.25$; ong handle, Acme strapped, 4 tine, $\$ 1.75$

Grass Hooks, or Sickles. English, 60c.; American, $50 \mathrm{c}$.

Grafting Wax. $1 / 4$ lb. 15 c., 1/2 lb. 20c., 1 lb. 35 c.

Hatchets. Medium, $\$ 1.00$; heavy, $\$ 1.50$.

Hoes, Draw or Field. 6 inch, solid socket, 75c.; 8 inch, solid socket, $90 \mathrm{c}$.

Draw. 7 inch, rivet socket, $40 \mathrm{c}$.; 8 inch, rivet socket, $50 \mathrm{c}$.

Acme Weeding. $4 \frac{1}{2}$ inch. Each $75 \mathrm{c}$.

Scuffle. 4 inch, 60 c.; 6 inch, 75 c.; 8 inch, 90 c.

Garden. 1 point, 40c.; 2 point, 50c.; 3 point, $75 \mathrm{c}$

Potato. 4 prong, 90c.; light, \$1.00; heavy, \$1.25.

Mehler's Handy. Each 85̃c.

Grub. Each 90c.

Hose, Rubber. Winner, 5 ply, per ft., 12c., Tiger, 6 ply, per ft., 15c.; Red Dandy, 7 ply, per ft., $17 \mathrm{c}$. Lion molded, per ft., 20c. Prices includes couplings.

Hose Nozzle. Graduating, spray, or solid stream, each $75 \mathrm{c}$.

Hose Reels. Wood to hold $50 \mathrm{ft}$., $\$ 1.70$; steel, to hold $50 \mathrm{ft} ., \$ 2.50$; wood, to hold $100 \mathrm{ft} ., \$ 2.00$; steel, to hold $100 \mathrm{ft}$., $\$ 3.50$.

Labels. Wood, for pots:

$\begin{array}{lrrrrr}\text { Size } & 100 & 1000 & \text { Size } & 100 & 1000 \\ 4 \text { in. } & \$ 0.20 & \$ 1.50 & 8 \text { in. } & \$ 0.30 & \$ 2.00 \\ 5 \text { in. } & .25 & 1.75 & 10 \text { in. } & .35 & 2.75 \\ 6 \text { in. } & .25 & 1.75 & 12 \text { in. } & .40 & 3.25\end{array}$

Lawn Rollers.

$\begin{array}{lccccr}\text { No. } & \text { Diameter Length } & \text { Sections } & \text { Wght. } & \text { Price } \\ 501 & 15 \text { in. } & 15 & 2 & 150 & \$ 15.00 \\ 502 & 15 \text { in. } & 22 & 3 & 200 & 18.50 \\ 504 & 20 \text { in. } & 20 & 2 & 250 & 20.00 \\ 507 & 20 \text { in. } & 24 & 2 & 300 & 22.50\end{array}$

Mattock. Handled, $\$ 1.40$.

Mole Traps. Reddick, powerful trap, easily set Each, \$1.25.

Picks. Light, 85̄c.; heary $\$ 1.15$

Plant Sprinklers. Rubber. Plain, \$1.15; angle neck, $\$ 1.25$.

Pruner, Tree (Waters'). S ft. $\$ 1.75 ; 10 \mathrm{ft.}, \$ 2.00$; $12 \mathrm{ft} ., 2.50$.

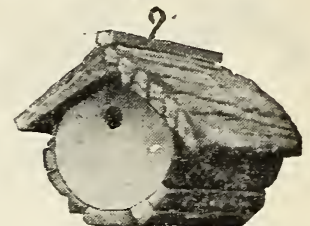

Rustic Bird House

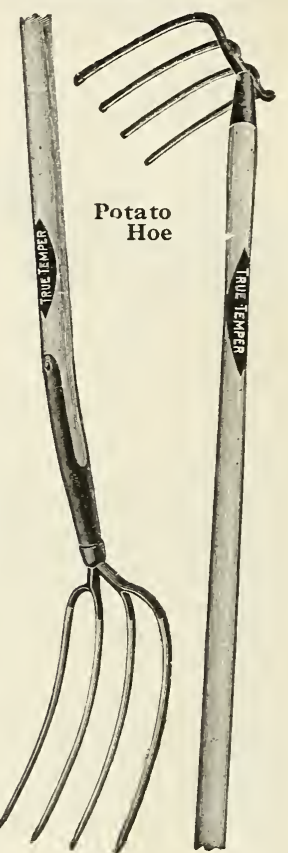

Acme Fork

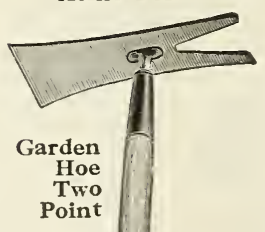

Point
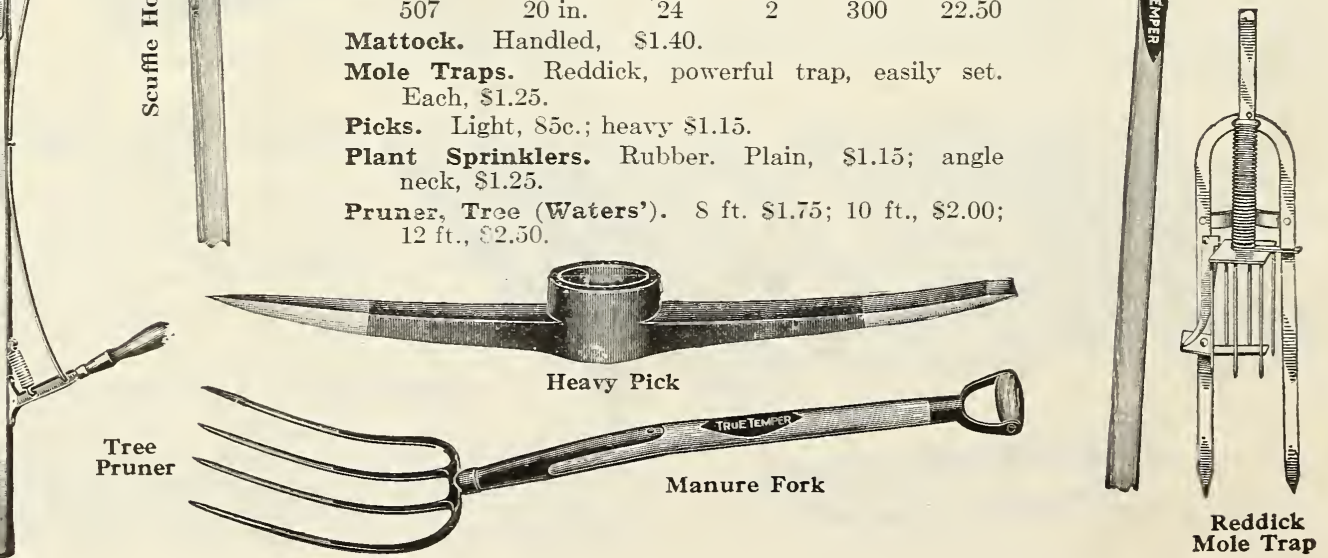


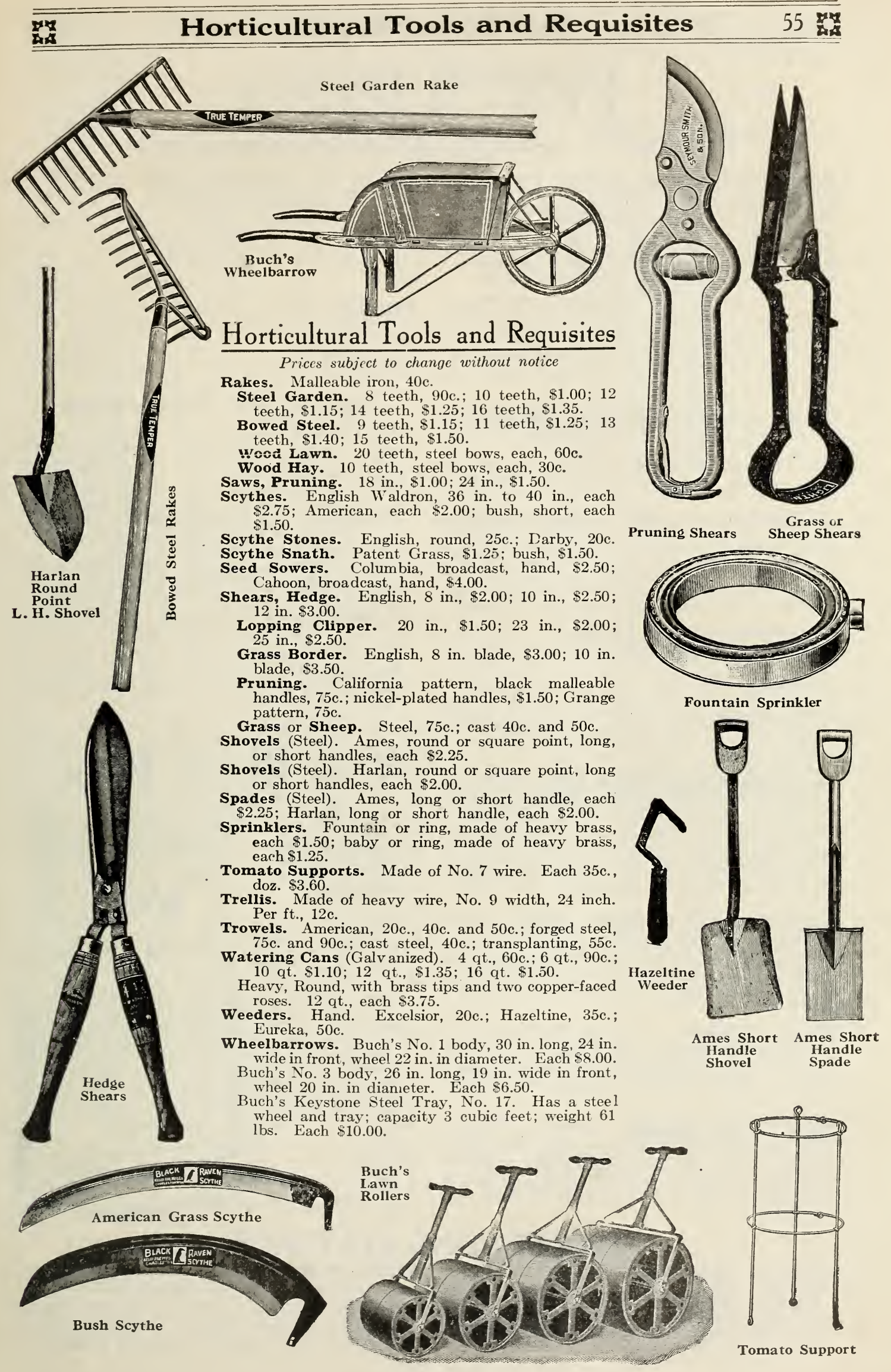


Schultz's Lawn Enricher $\begin{gathered}\text { For lawns } \\ \text { and grass lots. }\end{gathered}$ This superior dressing is made from chemicals, and is so prepared that it acts gradually throughout the season, producing a luxuriant growth of grass of a rich green color. It is far superior to lumpy, strawy manure which disfigures the lawn and gives off an offensive odor. It is nearly odorless, and is easily applied.

Directions for Using.-For making new lawns it should be applied at the rate of $25 \mathrm{lbs}$. for 1200 square feet, or at the rate of $800 \mathrm{lbs}$. per acre. As a topdressing for old lawns, use from 400 to 500 lbs. per acre; or for small yards, 6 lbs. to each 300 square feet. 5 -lb. pkg. $45 \mathrm{c}$., 10 -lb. pkg. $75 \mathrm{c}$., 25 -lb. bag $\$ 1.75$, 100 -lb. bag $\$ 6.00$, ton $\$ 100.00$.

\section{Ashes, Canada Unleached Hardwood}

Excellent top-dressing for lawns and grass land. They give to the grass a rich, dark shade of green, and will destroy many of the insects that are injurious to grass roots. A superior lawn dressing. 5 lbs. $25 \mathrm{c}$., $10 \mathrm{lbs}$. $50 \mathrm{c}$, 25 lbs. $\$ 1.00,100$-lb. bags $\$ 2.50,200$-lb. bbls. $\$ 4.50$.

\section{Concentrated Plant Food Tablets}

An odorless food for potted plants. Makes plants grow and bloom luxuriantly and drives troublesome insects from the soil. Takes the place of liquid manure. Explicit directions on each package. 10c. package contains 30 tablets; 25c. package contains 100 tablets.

\section{Pulverized Sheep Manure (Graz-It}

Analysis.-Ammonia, 2.25 per cent.; phosphoric acid, 1.25 per cent.; potash, 3.00 per cent. A rich, pure, natural manure. Excellent as a top-dressing for lawns. Its effect is immediate and lasting. It is recommended for the vegetable garden, promoting a steady and rapid growth. It makes a rich and safe liquid manure. $1 \mathrm{lb}$. to 5 gals. of water. $1 \mathrm{lb} .10 \mathrm{c} ., 5 \mathrm{lbs}$. $30 \mathrm{c} ., 25 \mathrm{lbs}$. $\$ 1.00$, 50 lbs. $\$ 1.75,100$ lbs. $\$ 3.00$, ton $\$ 50.00$.

Pure Raw Animal Bone Meal Analysis-$41 / 2$ to 5 per cent.; bone phosphate, 50 to 60 . per cent.; equivalent to phosphoric acid, 25 to 27 per cent. Pure animal bone can always be relied upon to give excellent results upon the growing crops, at the same time acting as a permanent improver, showing its results for several years afterward wherever it is applied. Bag of 200 lbs. $\$ 8.50$, ton $\$ 80.00$.

General Crop Grower Analysis. - Amcent.; phosphoric acid, 8 per cent.; potash, 2 per cent. This brand is intended as a general crop grower, and will be found equal in quality to any of the brands of this grade on the market. Sack of 167 lbs. $\$ 4.50$, per ton $\$ 50.00$.

\section{Truck Grower Analysis.-Ammonia, 4 per} cent.; potash, 4 per cent. This brand has been used largely by the most successful truckers and is prepared especially for early vegetables. Sack of $167 \mathrm{lbs}$. $\$ 6.50$, per ton, $\$ 70.00$.

\section{High.Grade Potato Analysis.-Ammonia,} phoric acid, 8 per cent.; potash, 3 per cent. This brand of goods possesses all the valuable elements of a highgrade Potato fertilizer. It can be used on all Potato crops with good results. Sack of 167 lbs. $\$ 5.50$, per ton $\$ 60.00$.

\section{INOCULATING CULTURES}

MULFORD CULTURES. Supplied for Alfalfa, Clovers, Vetch, Sweet Peas, Garden Peas, Garden Beans, and Lima Beans. Small size for Peas, Beans and Sweet Peas, 35c. postpaid. Garden size (1/4 acre) $75 \mathrm{c}$. , postpaid; 1 -acre size, $\$ 1.50$, postpaid; 5 -acre size, $\$ 5.00$.
Seven Per Cent Trucker Analysis. -7 per cent.; phosphoric acid, 6 per cent.; potash, 5 per cent. Truck growers require a special fertilizer to force their early truck for market. We recommend this fertilizer as giving the best results on Cabbage, Tomatoes, Melons and all kinds of regetables, which are grown for market. Sack of $167 \mathrm{lbs}$. $\$ 8.50$, ton $\$ 95.00$.

\section{Ten Per Cent Trucker Analysis. - Am-} cent.; phosphoric acid, 5 per cent.; potash, 3 per cent The highest grade manufactured. Very quick-acting fertilizer for plant beds. Matures crops at the earliest date. Sack of $167 \mathrm{lbs}$. $\$ 10.00$, per ton $\$ 112.00$.

\section{FERTILIZING MATERIALS}

NITRATE OF SODA. For regetables, apply at the rate of 100 lbs. to the acre, drilled close to the plants and slightly covered with soil. For grain and grass crops, apply broadcast at the rate of 100 to 125 lbs. to the acre, and cover slightly with the harrow. It is used principally in the Spring, just at the beginning of the active growing season. Price, per lb., 10c.; 25 lbs. or more, 8c. per lb.; 100 lbs., 6c. per lb.; per 200-lb. bag, $\$ 10.00$.

KAINIT, SULPHATE POTASH, MURIATE POTASH, GROUND ANIMAL TANKAGE. Prices on application.

ACID PHOSPHATE (South Carolina Rock). Analysis.-Available phosphoric acid, 16 per cent. Per 167-ib. bag, \$3.50; per ton, \$36.00.

LAND PLASTER. Excellent for composting, fertilizing or mixing with guano. Per sack (200 lbs.) $\$ 2.00$; per ton, $\$ 15.00$.

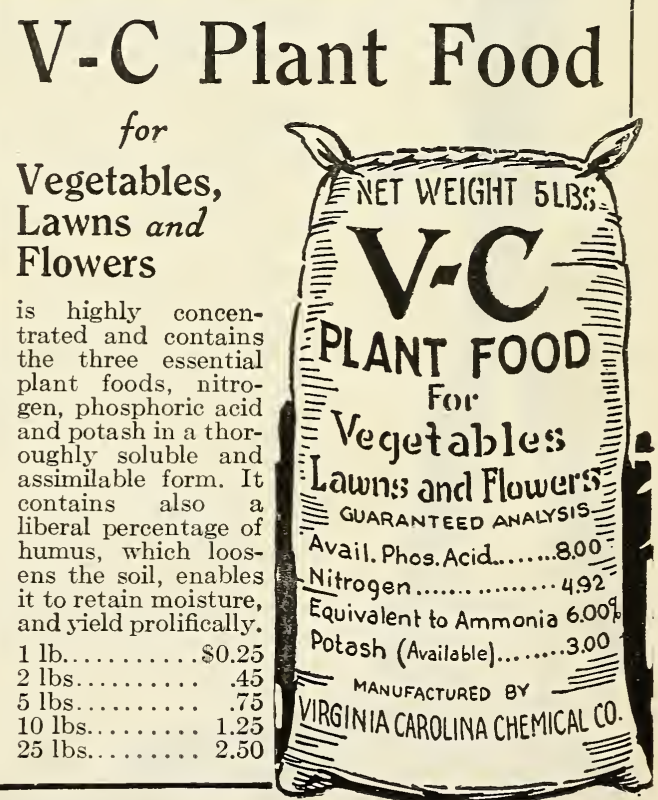

FARMOGERM. Supplied for all Clovers, Garden Peas and Beans, Sweet Peas and all other peas, and also for general use. In ordering, state what crop to be used for. Garden size, for $1 / 4$ acre, 50c.; 1-acre size, $\$ 2.00 ; 5$-acre size, $\$ 8.00$. Send for literature. 


\begin{tabular}{|c|c|c|c|c|}
\hline Date Received & Date Shipped & B) Whom & $\$ \ldots \ldots \ldots$ & $\begin{array}{l}\text { Please do not } \\
\text {-ifd white is } \\
\text { thes: spaces. }\end{array}$ \\
\hline
\end{tabular}

\section{ORDER SHEET for Vegetable and Flower Seeds Schultz's Seed Store ${ }^{304}$ Tenth Street N.W. Washington, D. C.}

Name

Ladies will please put the prefix MISS or MRS.

\section{Street Address \\ Box Number \\ R. D. \\ Post Office}

County

\section{State}

Express Cffice (If different $)$

Please forward Gocds by

State whether wanted by MAIL, EXPRESS, FREIGHT or STEAMER.
Date

\begin{tabular}{|l|l}
\hline Money Enclosed & Amount \\
\hline $\begin{array}{l}\text { Bills er Silver } \\
\text { (Regist the Letter })\end{array}$ & \\
Draft or Check & \\
Ex. Meney Order & \\
Postoffice Order & \\
Postage Stamps & \\
\hline Total & \\
\hline
\end{tabular}

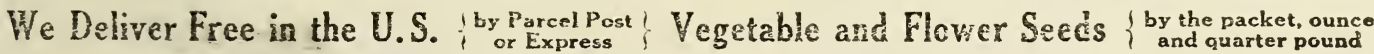

Purchasers pay transit charges on larger quantities of Seeds and other mcrchandise

We give no warranty, expressed or implied, as to description, quality cr productiveness of any seeds, plants or bulibs that we send out, and will not be in any way responsible for the cro?.-Schuitz's Seed Store.

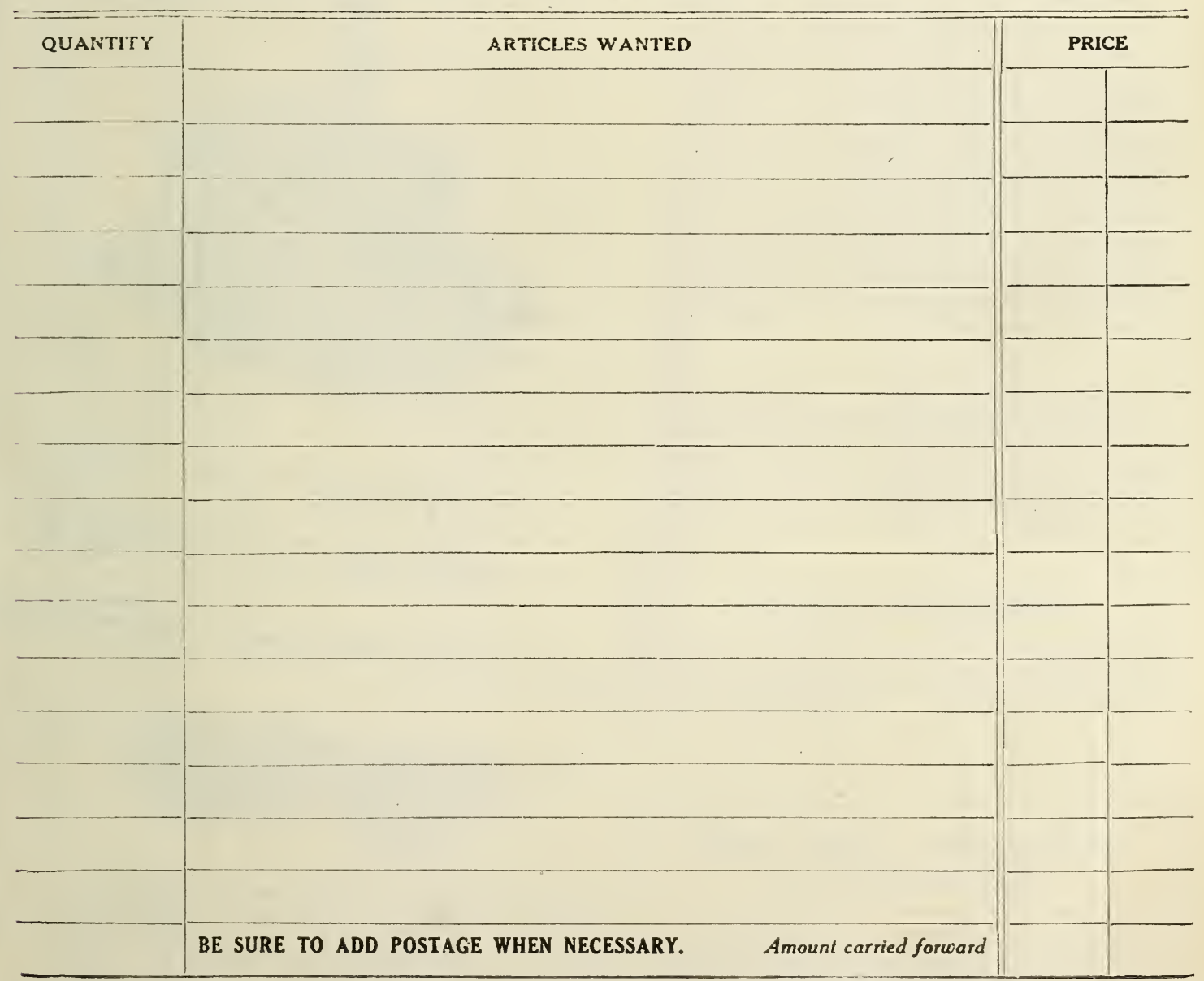




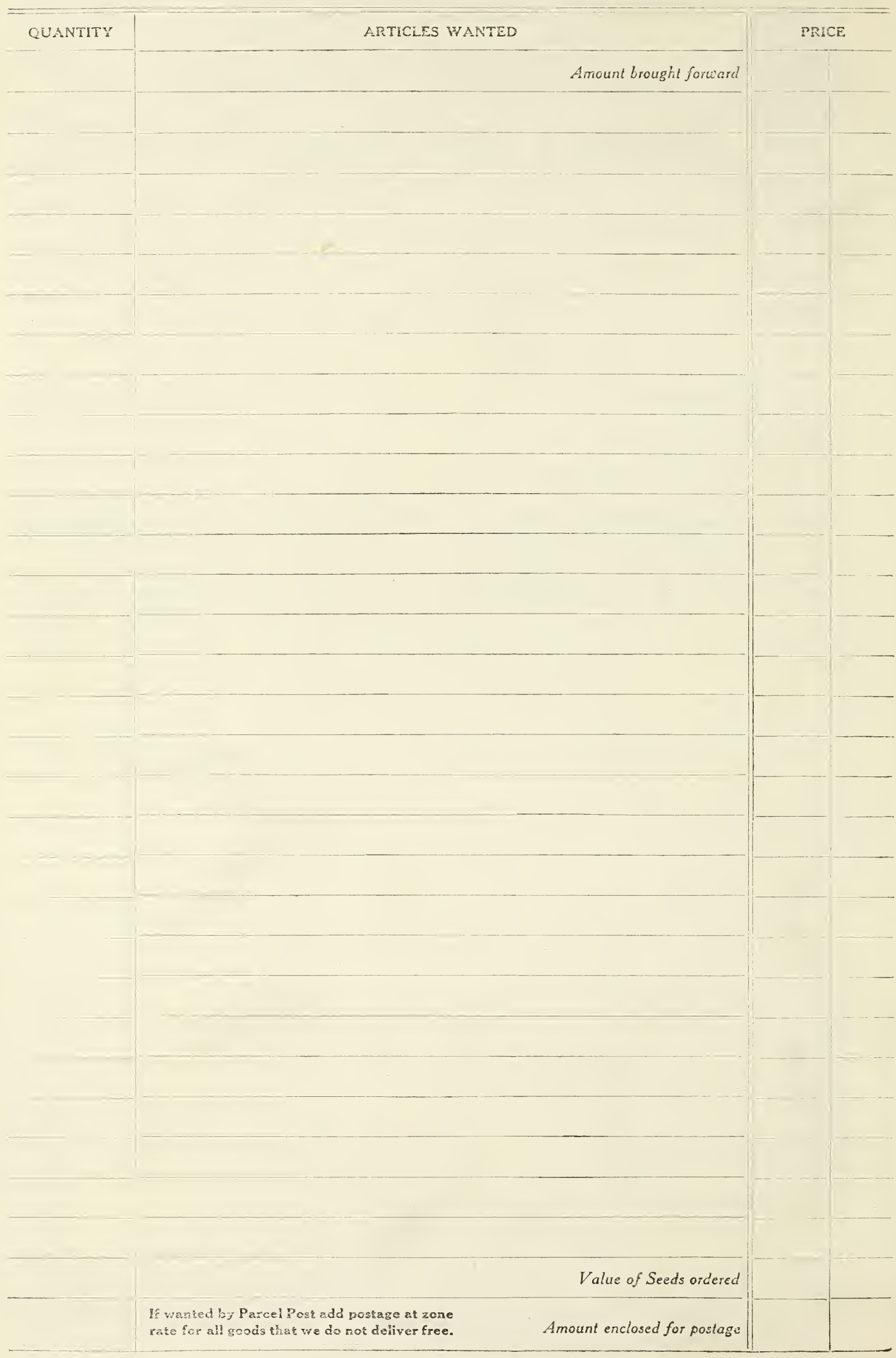




\section{LAWN}

\section{Coldwell's Imperial $\underset{\text { Bearing }}{\text { Plain }}$}

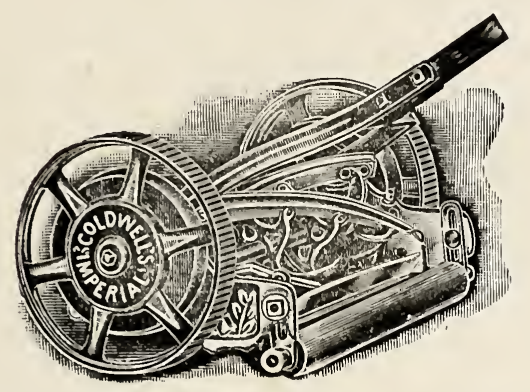

This machine is guaranteed to be the highest grade mower ever made. It has Coldwell's patent double edge channel knife which allows a new cutting edge to be brought into use should one be either injured or worn. It is made of the best material obtainale and is practically indestructible. Prices: 16 -in., $\$ 22.00$; 18-in., \$24.00; 20-in., \$26.00.

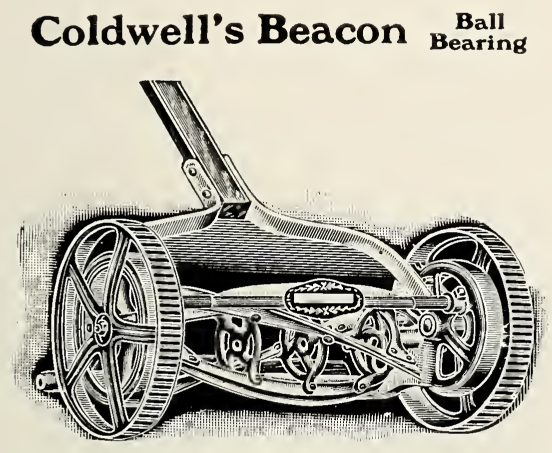

The "Beacon" is an easy running ball-bearing mower of exceptional value for the money. Owing to the design, it is light but strong and durable. The bottom knife is a solid steel blade, oil tempered and is adjusted to the revolving cutter in a simple but positive manner. Prices: 14-in., \$16.00; 16-in., \$18.00.

\section{Coldwell's Jewel $\underset{\text { Bearing }}{\text { Plain }}$}

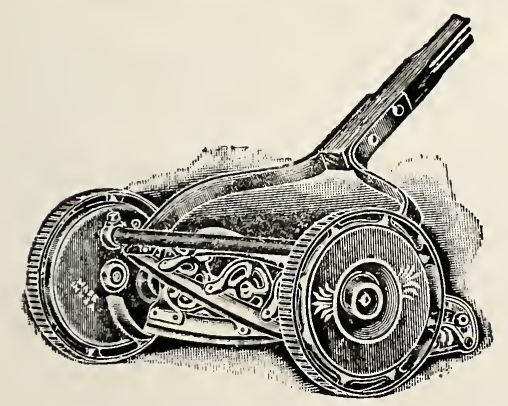

This mower with an 8-in. drive wheel is made to meet the demand for a good mower at a medium low price. It has a double ratchet and fine cut gears, which do away with the noise usually found in a cheap lawn mower. The bearings are provided with split brass bushings, by means of which all wear can be taken up. Prices: 14 -in., $\$ 10.50 ; 16$-in., $\$ 11.50$.

\section{Coldwell's Universal Horse Lawn}

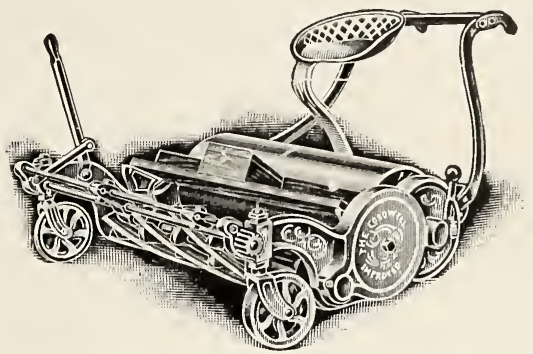

Coldwell's Universal Horse Mower is acknowledged by the trade in general to be the best horse mower made. In material, workmanship and finish it is unsurpassed. It is furnished complete (with the exception of the 25-in.) with seat, shafts and side draft attachment. This mower is made regularly with four blades in the revolving cutter, but when exceptionally fine cutting is desired, such as on golf links and very fine lawns, it can be furnished with six blades. These machines are used exclusively on all the parks of New York City, and all the prominent golf grounds throughout the country.

30-in. 4 blades complete. . . . . . . . . . . \$200.00 35 -in. 4 " " $\ldots \ldots \ldots \ldots \ldots \ldots \ldots \ldots 225.00$ 40 -in. 4 " " ............... 250.00

\section{Coldwell's Motor Mowers}

Coldwell's Motor Mowers are made in different styles to meet the varying demands for motor-driven lawn mowers. They combine all the advantages of a roller and mower. Coldwell's Motor Mowers have been on the market for over 15 years and are efficient and economical. They are equipped with the most modern type of motor, transmission and cooling devices. All materials used throughout, workmanship and finish are of the best. The amount of weight on the rollers has been determined by years of experience. The operation of these motor mowers is so simple that the average laborer can be taught to operate them in a very few hours.

\section{Lawn Mower Grass Catcher}

The E. Z. Catcher will fit every size of mower and consists of a galvanized iron bottom with canvas sides and back. The 16-in. will fit all sizes from 12 to 16-in.; 20 -in. all sizes from 18 to 22 -in. Each $\$ 2.00$.

\section{Horse Lawn Boots}

For use on golf links, tennis courts and fine lawns. Where care is exercised in ordering by size to fit the horse's feet, perfect satisfaction will be found. Price, $\$ 15.00$ per set of four.

\section{Lawn Mower Sharpening and Repairing}

We employ only practical men to attend to this work, those who thoroughly understand their business, and we guarantee all machinery repaired by us to do satisfactory work. 


\section{- ZINNIAS -}

\section{Schultz's Giant Double}

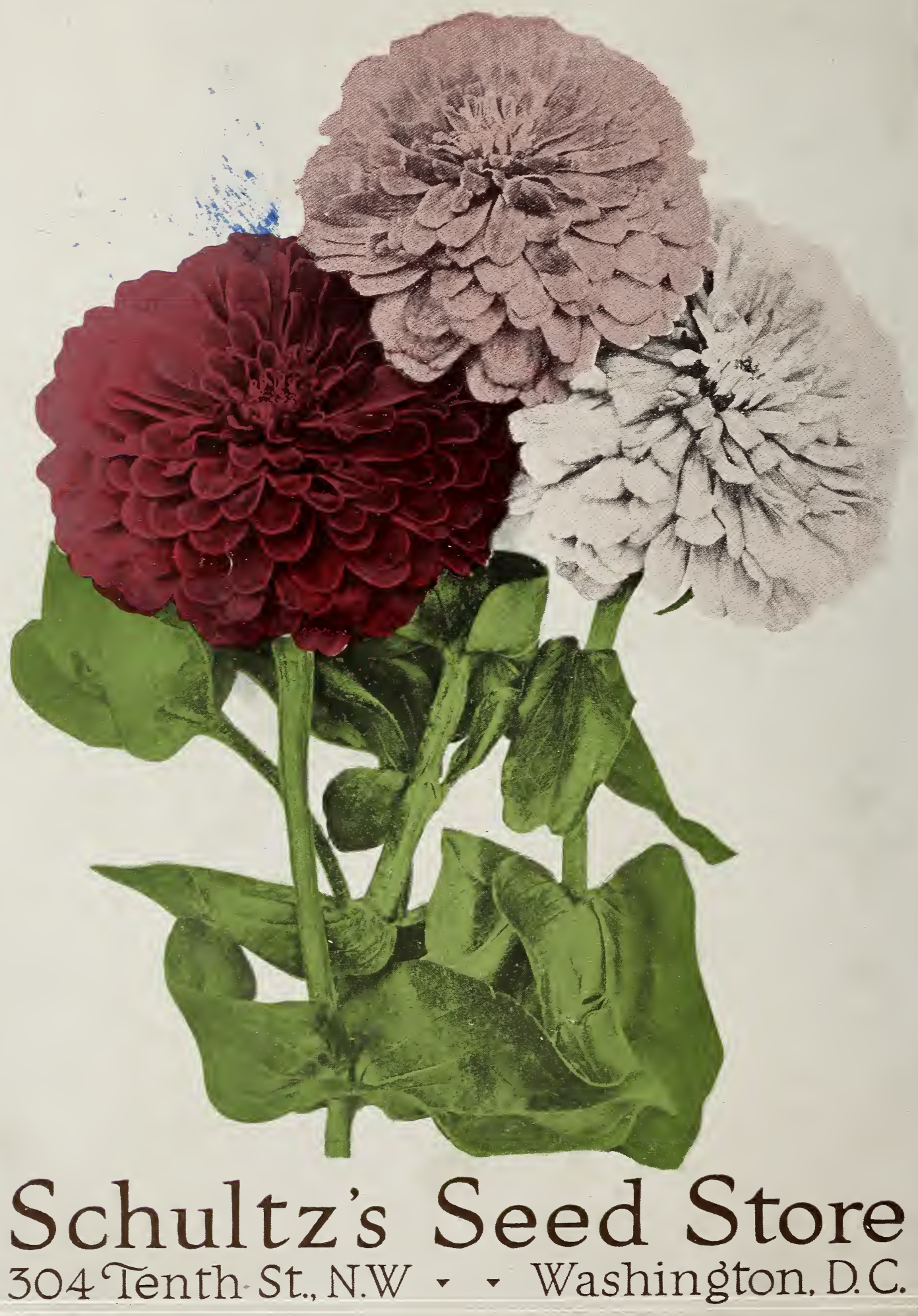

